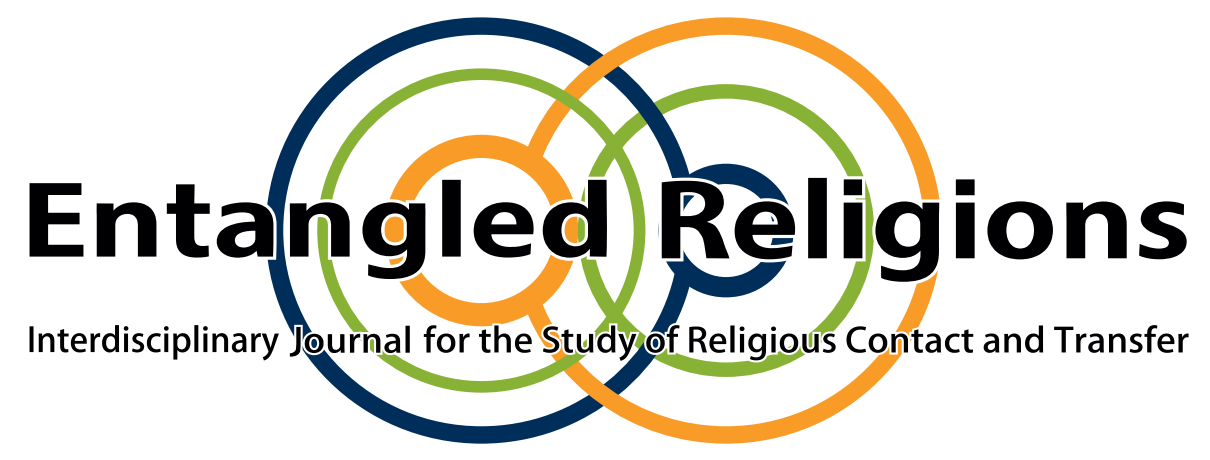

Special Issue

\title{
The Changing Landscapes of Cross-Faith Places and Practices
}

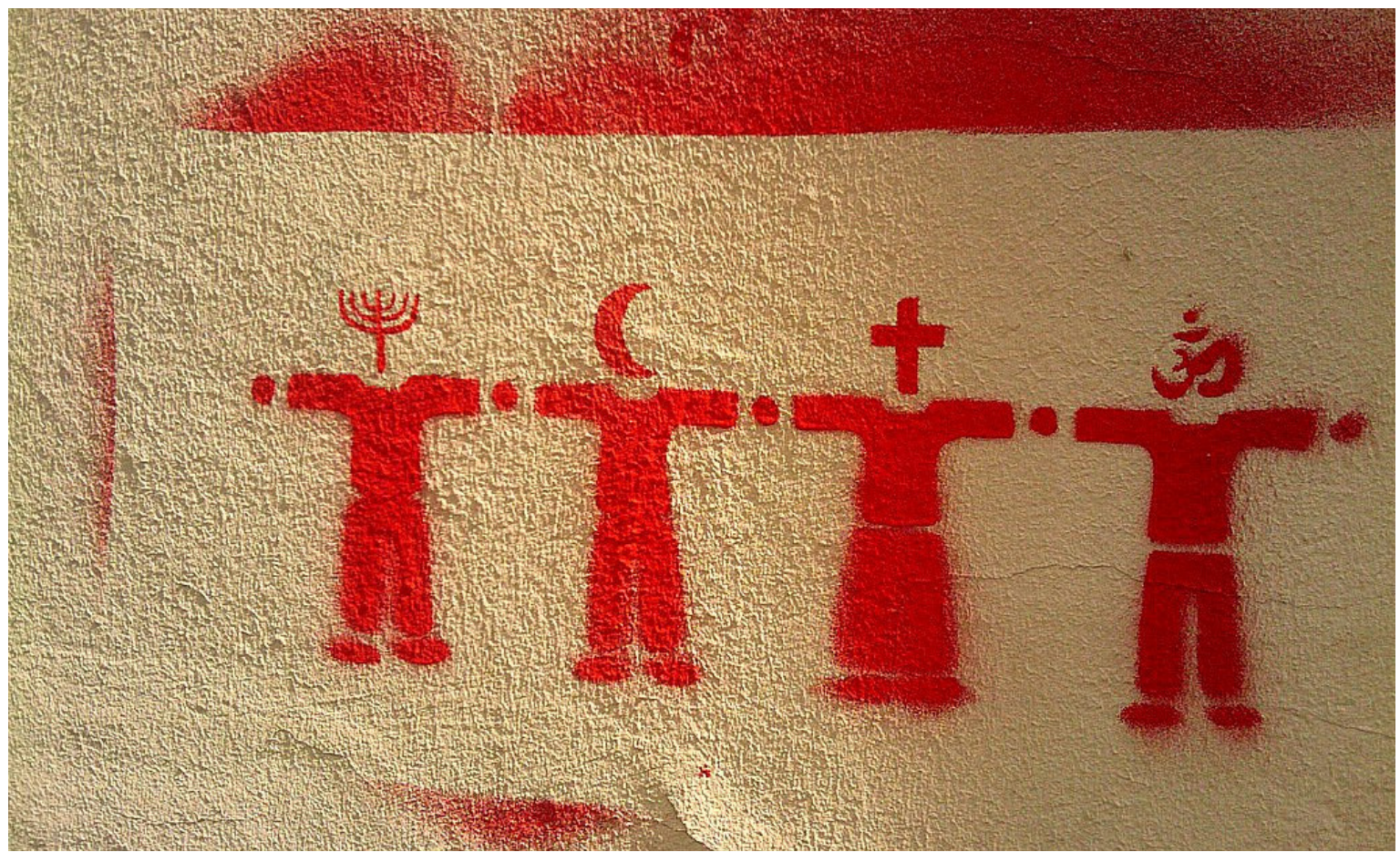

Entangled Religions 9 (2019) http://doi.org/10.13154/er.v9.2019.1-272

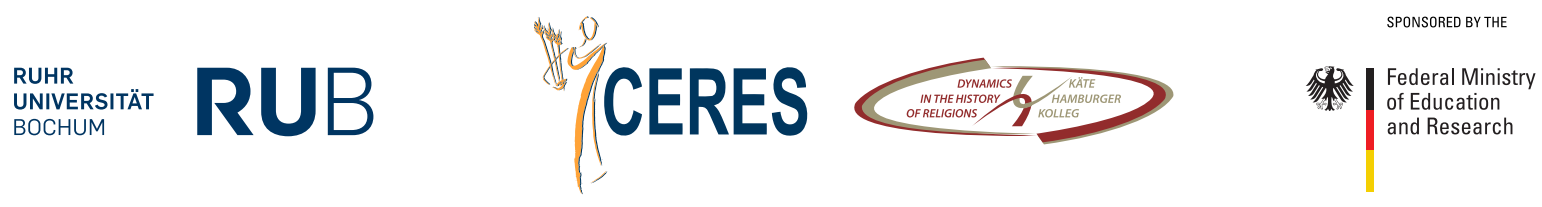




\section{The Changing Landscapes of Cross-Faith Places and Practices}

Introduction: (How) Do We Share the Sacred?

Manfred Sing

Sacred Spaces in a Holy City. Crossing Religious

Boundaries in Istanbul at the Turn of the Twenty-First

Century

Méropi Anastassiadou-Dumont

A Muslim Holy Man to Convert Christians in a

$57-78$

Transottoman Setting: Approaches to Sarı Saltuk from

the Late Middle Ages to the Present

Stefan Rohdewald

Spirit of Place and Nation Building: Kosovo and Bosnia

from Imperial to Post-Communist Times

Tanja Zimmermann

Shared Shrines and the Discourse of Clashing Civilisations

$108-138$

Glenn Bowman

Digressions on Polytropy: An Exploration of Religious

Eclecticism in Eurasia

Dionigi Albera

Where Do the Multi-Religious Origins of Islam Lie? A

Topological Approach to a Wicked Problem

Manfred Sing

Towards a Multi-Religious Topology of Islam: The Global Circulation of a Mutable Mobile

Manfred Sing 


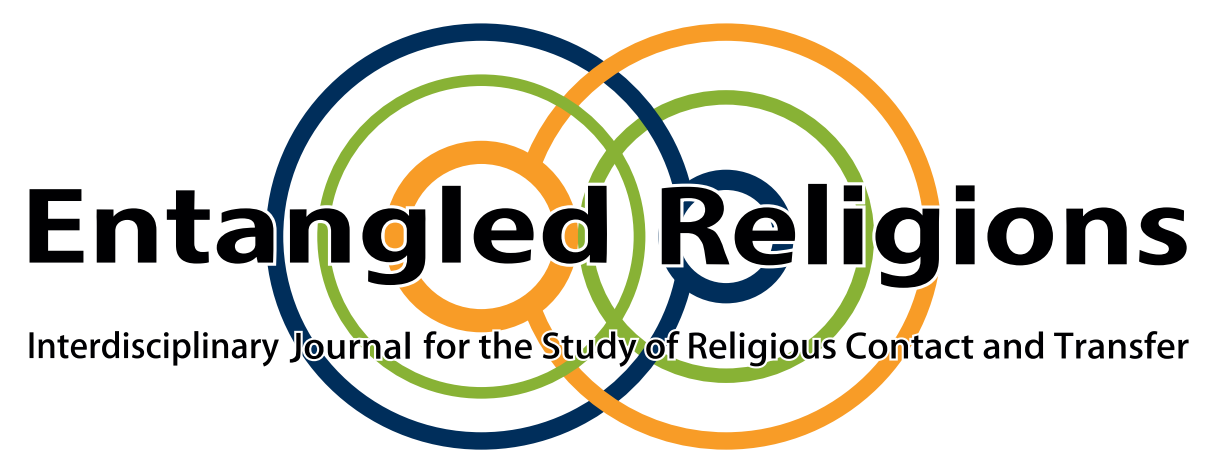

\section{Introduction: (How) Do We Share the Sacred?}

MANFRED SING

Leibniz Institute of European History, Mainz, Germany

This contribution to Entangled Religions is published under the Creative Commons Attribution 4.0 International Public License (CC BY 4.0 International). The license can be accessed at https://creativecommons.org/licenses/by/4.0/legalcode.

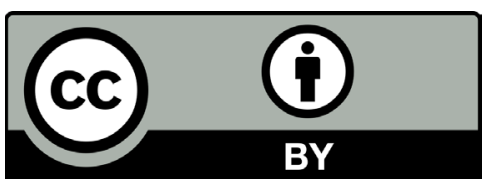

Entangled Religions 9 (2019) http://doi.org/10.13154/er.v9.2019.3-33
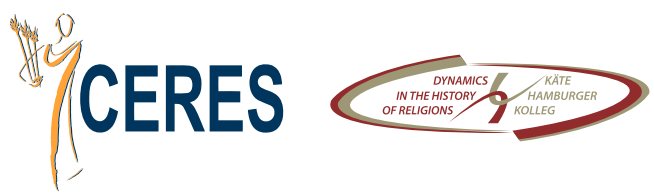

SPONSORED BY THE 


\title{
Introduction: (How) Do We Share the Sacred?
}

\author{
MANFRED SING \\ Leibniz Institute of European History
}

\begin{abstract}
Multi-religious cohabitation bears immense social and political implications, since the question of how multi-religiosity should be organized has become a hotly debated topic all over Europe. Although religious diversity has turned into an everyday experience in many parts of the world today, a perception that understands conflict between religions as inevitable still holds sway and has maybe even grown stronger, especially after violent events such as the terror attacks of 9/11 and the recent upsurge of political populism in Europe and the Americas. A historically informed perspective that illustrates the widespread dissemination of religious mixture and the commonness of religious interaction throughout the centuries, however, may help us to see current debates in a different light. The present focus edition is dedicated to this purpose.
\end{abstract}

KEY WORDS shared sacred places; inter-religious encounter; polemics; room; place; space

\section{Introduction}

Places and events shared by adherents of different faiths are by no means historically exceptional; on the contrary, they are well documented for Asia, Europe, and Africa, and are no less characteristic for the three monotheisms around the Mediterranean basin (see e.g. Albera 2008; Couroucli 2012). The historiography and anthropology of such phenomena not only challenges the ascription of a singular religious identity to sacred places and religious events; it also questions simple narratives about the relation between the religious monopoly on truth and multi-religious cohabitation, understood as either functioning smoothly or stillborn. Thus, while some scholars in the social sciences believe that political stakeholders nurture religious conflicts, others hold the opposing view that if such conflicts are socially constructed, then inter-religious spaces, expressing religious toleration, can and should also be established.

Obviously, however, there is no automatism either for violent conflict or for peaceful coexistence. Therefore, it seems appropriate in the studies of multi-confessional and multi-religious spaces to leave the "either-or" logic behind and rather proceed from a middle ground that directs attention to the possible richness and diversity of examples and the paradoxical "interplay of sharing and competition, tolerance and antagonism, 
mixed worship and the destruction of other's shrines" (Albera 2008, 40). If we talk about shared sacred places, the ambivalent expression "shared" already hints at the fact that wherever people do something together or have something in common, there are simultaneous processes of distinction, demarcation, and division at work.

As religious competition and religiously legitimized violence have occupied academics as well as policymakers for quite some time now, a focus on place and space also seems a way to foster a better understanding of the underlying dynamics. As space, and especially sacred space, is a limited resource, the allocation of space between different groups is likely to be highly contentious, not only in land-scarce circumstances but also in secular ones, when competing claims to the use of spaceand the visibility of this use-are laid by different religious or secular actors.

This introduction gives a short overview of the historiography and anthropology of shared religious places and practices and spells out the knowledge interest of the present volume in relation to the wider field of research. I start with discussing the challenges of multi-faith rooms in contemporary societies and non-religious environments-an issue that most readers are certainly aware of, as it pops up regularly in the media. I then move on to the historiography of shared religious sites more generally and explain how the contributions of the current volume pick up on some of the main topics that have been treated by scholars in the field. After that, the underlying theoretical concepts of place, space, and the sacred are discussed in relation to recent scholarly debates. In the next two sections, some of the earliest historical examples of sharing and polemics between the three monotheistic religions as well as examples of not sharing are presented; these examples are meant to give a more complex picture of multireligious cohabitation. After this overview, the focus of the present volume will become clearer, which is to discuss changing inter- and trans-religious practices against the background of changing religious, cultural, and political landscapes. The authors' aim is to contribute to a complex and more comprehensive picture of the multiplicity of crossreligious relations and their historical transformations. For this purpose, this special issue of Entangled Religions brings together articles that approach the subject from different angles and disciplinary backgrounds-history, art history, Byzantine Studies, Eastern European and Ottoman Studies, Islamic Studies, anthropology, and sociology. The collection of these contributions aims to take stock of the research results of the last two decades, sum them up, discuss them in new light, reflect on them theoretically, and move in new directions. 


\section{Multi-Faith Rooms in a Non-Religious Environment}

A case that demonstrates the complexities of religious sharing is the installation of multi-faith rooms, which has become the norm even in many non-religious environments-in hospitals, retirement homes, prisons, schools, universities, shopping malls, exhibitions centres, train stations, and airports. Some scholars, such as Groß (2000), believe that there will be a growing demand for multi-faith rooms due to growing global mobility, giving rise to inter-cultural encounters, and a growing longing for oases of tranquillity against the noisiness of daily routine and the commodification of public space. Often, however, such rooms do not exactly fulfil the purpose for which they were built but create new challenges for those who go in and those who stay out. Muslims in European cities often find they do not get exactly the prayer room for which they had campaigned. The problem mostly stems from the fact that multi-faith rooms try to integrate religious diversity into a previously non- or mono-religious institution.

Re-structuring an already existing room, institutions often tend to favour one of four solutions in order to signify religious openness: universalization, emptiness, hiding, or parcelling (see Nagel 2015). Each of these solutions creates other difficulties, since they reconcile diversity with religious feelings in different ways. The first solution, the representation of the symbols of all major religious traditions, can hardly include all minorities and may irritate some believers who possibly feel disturbed by "rivalling" symbols. Therefore, this option is primarily adopted by avowedly multi-religious initiatives, like the Houses of Religions in Hannover and Bern, which have been founded through the cooperation of adherents from seven and eight faiths, respectively (e.g. Hauck-Hieronimi 2015). The second option, the radical abandonment of religious symbols-although creating religiously neutral places-easily fosters a feeling of incompleteness and risks leaving all believers equally unsatisfied. The third option, to move partition walls inside a room or illuminate certain parts of it according to one's own wishes, is not only a complex matter prone to error, but becomes even more intricate in simultaneous use. The subdivision into clearly designed parcels, if possible at all, often happens within a construction that is clearly identifiable as originally Christian or non-religious and thus often reflects a provisional nature. All four solutions integrate religious equality, symbols of specific religious cultures, religious minorities, and non-denominational groups to a different degree.

The result of these difficulties can best be observed at international airports, where different rooms for prayer, recreation, meditation, and relaxation-variously called multi- or inter-religious-co-exist. The first prayer rooms at airports were not inter-religious. A first-Catholic_chapel was opened at Boston Airport in 1951. In 1967, care for airport chapels was institutionalized by the foundation of the International 
Association of Civil Aviation Chaplains (IACAC). Starting in the 1980s, some of the chapels were transformed into inter-religious arrangements (Justnik 2008). From an anthropological point of view, it appears paradoxical that airports, as paradigmatic "non-places" (Augé 1995) which serve as areas of transit, not of interaction, should accommodate places where people of different faiths and cultures are supposed to meet.

Frankfurt Airport, for example, is not only a transit area but also the biggest local workplace in Germany, with 80,000 employees working for 500 companies and institutions. In 1969, the first chapel was opened at the airport (Beinhauer-Köhler and Meyer 2015, 195); in 1972, rooms for Catholic and Protestant airport chaplain services were installed. ${ }^{1}$ In the 1980 s, Fraport-the company which operates Frankfurt Airportdecided to expand the facilities for prayer rooms, and since then, the availability of such rooms has been increasing and diversifying in the publicly accessibly terminals as well as in the transit areas. Today, Frankfurt Airport offers nine prayer rooms for Christians, Jews, and Muslims, as well as two religiously neutral "Quiet Rooms," two yoga rooms, and several areas with "silent chairs" sealed behind noise-reducing glass-probably the most diverse ensemble of prayer and meditation possibilities in an airport worldwide. ${ }^{2}$

The establishment of rooms for praying as well as pastoral and social services was neither simply religiously motivated nor does it primarily aim at inter-religious exchange; Fraport must balance economic and pragmatic considerations when responding to spiritual, social, and psychological needs. At the end of the day, such rooms aim at the success of the airport's operations and the satisfaction of passengers and employees (Beinhauer-Köhler and Meyer 2015, 197f.), and can contribute to the locational advantage of the airport. Therefore, the arrangement of prayer and meditation rooms at the airport is not fixed but subject to constant changes that result from a spatial and economic dynamism affecting the airport as a whole (ibid., 198). Although the four main prayer rooms were accommodated side by side in a long and dreary corridor in the public area of departure Hall B in Terminal 1 (ibid., 195) for several years, this inter-confessional and inter-religious arrangement finally came to end in February 2019. The Orthodox room has definitively been closed. The Jewish room has been moved to departure Hall C, where it is easily locatable and accessible close to the check-in counters that operate El Al flights. And a new, circular, and much bigger Muslim prayer room has been opened in Hall E of Terminal 2, where an adjacent "Room of Quiet" is also located. Even the remaining ecumenical chapel will be relocated in the corridor that faces a complete renovation. Thus, the official inter-religious activities

1 Author's interview with the Catholic airport chaplain Heinz Goldkuhle SAC, 17 January 2019.

2 Author's interview with Fraport's diversity manager Christian Meyer, 17 January 2019. 
are now basically reduced to the annual festival of the "Abrahamic religions" that was established in 2001 as a reaction to 9/11 and consists of common prayers, speeches, music, and food at a lively point in the airport, the transition area to the train station.

As the institutionalization of the three monotheistic religions at the airport follows a different pattern, their presence and representation is also different, although all of them offer regular prayer times for passengers and workers. The staff of the Protestant and Catholic churches is deeply involved in the social and psychological services at the airport, including care for people in need of help, deportees, refugees, and surviving dependants. For Jewish matters, the rabbinate in Frankfurt city is responsible. The organization of Muslim prayer times and a calm operation during Ramadan or Hajj season is delegated to a Muslim employee of Fraport. Earlier counselling with DiTiB, the Turkish-Islamic Union for Religious Affairs (ibid., 200), has been terminated by Fraport to avoid inciting intra-Muslim, ethnic, or political rivalries. ${ }^{3}$ The example shows that in such a non-religious environment, religions are not wholly self-sustained entities but that Fraport plays the role of the "landlord," controlling the religious services that are offered inside its facilities and trying to restrict activities that may disturb daily routines.

Religiously neutral rooms at airports are located in a very different practical and symbolic context. The clientele and function of the so-called "Quiet Rooms" are more dubious than the purpose of traditional prayer rooms. Some are understood as interreligious places, like the rooms at Munich Airport and Vienna Airport, and some as religiously neutral, like the two rooms in Frankfurt Airport. Although some "Quiet Rooms" are consecrated during inauguration, as was the case in Munich and Vienna in 2005 and 2008, respectively (Löffler and Nikitsch 2008), they normally do not offer worship services but rather address individual and non-denominational travellers. In an atmosphere created by pleasant lighting, warm colour effects, and universal symbols made of wood, stone, or water, the rooms' aim is to encourage visitors to linger, no matter whether they stay for prayer and meditation or simply imbibe the silence. The model for this kind of room is a small meditation chamber at the United Nations headquarters in New York, called "Room of Quiet," which is characterized by a rhombic shape, dim light, an abstract painting, and a heavy block of iron ore from Sweden, put in the middle of the room. Opened in 1957, it was planned and supervised during construction by General-Secretary Dag Hammarskjöld (d. 1961), who had made the room his personal project. In a kind of manifesto, he explained that the room is meant to symbolize the universal longing for peace and harmony, independent of the viewers' faith and origin (Kletke 2000; Kuschel 2010, 5-7). It is certainly an ironic turn that this 
iconic multi-religious and multi-cultural room-that embodies the UN's foundational credo in such a simple, yet vivid form-is neither signposted nor part of the guided visitor tours; as a result, visitors who do not know of its existence will hardly find it (Kletke 2000, 98).

The yoga rooms at Frankfurt Airport form yet another category of spiritual rooms. Fraport advertises them in a video in which you can watch "FRAnky"-a human robot, dressed as an airplane-taking the escalator to a yoga room with a yoga mat under one of his wings and then finally performing parts of the sun salutation in one of the rooms. The message reads, "Get your yin back into the yang at Frankfurt Airport's free yoga rooms."

Such examples of "inter-religious" rooms for inner reflection, but without pastoral service and religious community, raise the question of how far they imitate or even parody religion in order to create the impression of representing a sacred place without being one (Jonas 2008). More critically, the question arises whether such rooms re-enact the extinction of historical places: they exemplify the expectation of the modern subject to emancipate herself from local and historical conditions and positively relate to de-localization and de-historicization (Spiegel 2008). Implicit in such a view is an ideological understanding of secularism and religion which assumes that peaceful inter-religiosity can only take place in spaces stripped of their local tradition and religious history. It is not that the airports, which also offer spaces for traditional religions, would openly subscribe to such a "philosophy." However, the exhibition of the photo artist Andreas Duscha (Justnik and Feldhoffer 2008), who took pictures of multireligious rooms in international airports on all continents, reveals an assemblage of sometimes carelessly arranged and sometimes over-designed spaces, thus reflecting an absurd organization of religious and cultural juxtaposition, fragmentation, and meaninglessness (Spiegel 2008, 19; Kölbl and Duscha 2010). ${ }^{5}$

The collection of the following articles is rather dedicated to an opposed approach. It traces the local and historical rootedness of cross-religious encounters connected to specific places, figures, and festivities. On the one hand, it shows the endurance as well as the constant transformations of multi-faith practices and landscapes throughout history. On the other hand, it indicates that the modern construction of inter-religious rooms grapples with new challenges, but also similar difficulties visible in historical examples of commonly used sacred sites. In this respect, multi-religious initiatives

4 See https://www.frankfurt-airport.com/en/travel/transfer.detail.suffix.html/service/at-the-airport/ yoga-rooms.html. Accessed February 1, 2019.

5 See a selection of his photos on his website https://www.andreasduscha.com/Places-of-Worship. Accessed March 22, 2019. 
in secular societies can certainly learn a lot from diverse examples of multi-religious cohabitation studied by historians and anthropologists.

\section{The Historiography and Anthropology of Shared Sacred Places}

The British historian and archaeologist Frederick W. Hasluck (1878-1920) is credited as one of the most important pioneers of research about what he called "ambiguous sanctuaries." He drew attention to the interplay of Christianity and Islam in his publication Christianity and Islam under the Sultans in 1929, posthumously edited in two volumes by his wife Margaret Hasluck (1885-1948). Before the publication of this work, the Haslucks had travelled in Asia Minor, Greece, and the Balkans regularly since 1904. Among other things, Frederick Hasluck studied commonly venerated saints, such as Khidur and Sarı Saltuk, and pointed at processes of Islamization behind superficially mixed religious practices. His pioneering role and influence has recently been confirmed by a series of essays critically re-evaluating his work, published in three volumes by the anthropologist David Shankland (2013).

As Tijana Krstic (2013) argues in one of Shankland's volumes, the reception of Hasluck's work followed a somewhat weird trajectory. Hasluck had pointed out that the "apparent equality" between Christianity and Islam in Bektashi shrines or in figures such as Sarı Saltuk was "only superficial” (Krstic 2013, 252). He also held that the ultimate aim of the Bektashi inter-religious activities in the Balkans "was not to amalgamate Christianity with Bektashism on equal terms, but to absorb Christianity into Bektashism" (ibid.). In spite of this, Hasluck's work became "inextricably intertwined with the discourse of syncretism" (ibid., 249) throughout the twentieth century. Hasluck's study entitled "Ambiguous Sanctuaries and Bektashi Propaganda" became particularly "emblematic" (ibid., 251) in this regard, not only as "primary example of syncretism" (ibid.) but also for the thesis that proselytizing antinomian "heterodox" dervishes had been the main agents of Islamization in Anatolia and the Balkans. Although Hasluck never used the word "syncretism" (ibid.), scholars referencing him contributed to the spread of the word in Ottoman studies at a time when it was increasingly falling out of use in the studies of religion (ibid., 247).

The lasting impact of Hasluck's work is visible in the fact that in this special issue, several authors pick up on questions raised by Hasluck and his successors. Stefan Rohdewald critically discusses the inter-religious aura ascribed to the saintly figure of Sarı Saltuk. Méropi Anastassiadou-Dumont points at the "Islamization" of sacred Christian places in contemporary Istanbul that were formerly visited by both 
Christians and Muslims but have become mainly Muslim due to the dwindling presence of Greeks. Dionigi Albera and Manfred Sing continue the theoretical debate about orthodoxy, heterodoxy, and syncretism by proposing new concepts to approach religious diversity-"polytropy" and "multi-religious topology."

David Shankland's (2013) volumes in honor of Hasluck bear testimony to the fact that academic interest in inter-religious sharing has increased in the last two decades, maybe as a reaction to popular prejudices about religious violence or violent religions. Recently edited volumes treat phenomena connected with inter-religious encounters with different foci and from various disciplinary backgrounds. From a background in the studies of religion, Beinhauer et al. (2015) analyze contemporary, multi-religious spatial arrangements in Western European societies. From a background in anthropology and the studies of religion, Albera and Couroucli (2012) deal with shared sacred places in the Mediterranean region, while Darieva et al. $(2017 ; 2018)$ focus on the Caucasus and Bowman's (2012) volume covers a wide range of regions from the Balkans to Nepal. Harris et al. (2012) as well as Barkan and Barkey (2014b) approach the same subject from a historical point of view and share an interest in the historical emergence of multi-religious spaces in areas of the Byzantine and Ottoman Empires.

One of the major questions in these volumes is why and when religious sharing turns into intolerance and violence. The anthropologist Robert M. Hayden has provided one of the most discussed answers to this question. In an article published in April 2002, he coined the telling terms "antagonistic tolerance" and "competitive sharing," which he later elaborated further (Hayden 2015, 2016). According to him and his followers, the sharing of holy places, though it seems to be a widespread practice, is no act of equality and permanence but only represents a transitional truce between two or more antagonistic groups-a temporal moment in which they realize that they are each unable to overcome the other. In this model, the dominant group only accepts the presence of other groups as long as it cannot expel them. Although subordinated groups are permitted to use a shared site, this is far from equal democratic sharing and only expresses both strategic acquiescence and latent conflict. Hayden (2002, 219) concluded that "diversity seems best to thrive under conditions that deny democracy (thus preventing the imposition of the will of the majority group) or display clear subordination of one group to another." Referring to contemporary Bosnia, he remarked, "attempts to impose diversity after a country has been partitioned may well require indefinite occupation to deny power to the nationalists for whom people would vote if given the chance to do so" (ibid.).

Hayden's article exemplifies that the academic interest in holy places is, like holy places themselves, not disentangled from contemporary issues. Hayden's take on "religious sites in South Asia and the Balkans" was very much framed through his focus 
on violence in the Jugoslav wars and "ethnic cleansing" in Bosnia in the 1990s (ibid., $205,213,214,216,219)$. Although the text draws from intellectual history as far back as John Locke, it seems more suggestive to assume that the author also re-thought his earlier research and came up with his "discomfiting" (ibid., 219) analysis under the impact of $9 / 11$, although this is not mentioned. The framing of shared sacred sites versus religious violence is by no means an exception. Barkan and Barkey (2014a, 2), for example, formulate four variations of the question of how to understand violence and conflicts "in such sacred settings" in their introduction of their edited volume.

Such a framing runs the risk of nurturing different problematic assumptions, such as the idea that monotheistic religions claim an exclusive monopoly of truth and must therefore be intrinsically violent and unable to share holy sites. Such assumptions also fit well with Huntington's (1996) thesis of the "clash of civilizations." Another problematic conclusion drawn from this framing could be a dichotomy between practices of sharing and the will of not sharing, although there is a multiplicity of forms of exchange and various degrees of interaction at shared sites, including "open conflict, antagonism between groups, uneasy coexistence, amiable mutuality, and forms of syncretism" (Barkey 2014, 46). Glenn Bowman, who has critically contributed to the debate about "antagonistic tolerance" since its beginning (Bowman 2002), revisits the debate and his contribution to it in this volume and puts it in a wider political context. He critically discusses the detrimental and self-fulfilling effects of discourses that turn identities into exclusive properties: "Sharing, or even mixing, is there rendered contentious, and local events in which individuals with different allegiances clash come to be read more widely as indubitable signifiers of irresolvable antagonisms."

Maybe the strongest objection to the model of an "antagonistic tolerance," in which cohabitation represents only a transitional phenomenon, is the historical argument that shared practices and sites existed for centuries, in spite of political, social, and violent ruptures-such as the rise and fall of empires, migratory movements, conversions, conquests, and wars-, in spite of the transition from colonial to post-colonial conditions, and in spite of nationalist or atheist state policies. There is ample evidence that numerous shared sites and pilgrimages survived even in the face of adverse conditions. However, it would also be one-sided to overlook these adverse conditions, visible in the forced conversion of sacred monuments. Barkey $(2014,53 \mathrm{f}$.), drawing on Bryer (1979), gives the decreasing numbers of monasteries that came under Seljuk, Ottoman, and Turkish rule as an example: Out of 417 urban monasteries known within the borders of the Byzantine Empire in the twelfth century, 80 still existed at the eve of the Ottoman conquest, 20 remained after 1453, and 6 continued to modern times. In the rural case, of the 283 rural monasteries, 158 existed on the eve of the Ottoman conquest, 91 survived after, and 62 continued into the modern period. 
These numbers reveal a complex trajectory that is extremely uneven between urban and rural areas. Under the same conditions, the percentage of urban monasteries fell to 1.4 percent of the amount in the twelfth century, while it was still at 21.9 percent in rural areas after eight centuries; this means a fifteenfold difference. Although the decrease in monasteries does not directly relate to shared sites but rather to a generally changing multi-religious space, the numbers fit Ora Limor's $(2007,231)$ assumption well that

to the extent that the holy site in question is more institutionalized and closer to the centre of religion, and to the extent that the tradition represented there is more central to the structure of the faith, exclusivity will be emphasized and border-lines more sharply marked. A syncretistic ritual is feasible at sites more remote from the geographical, institutional, and ideological centre, and it may be reviewed as 'grass-roots' religious phenomenon, rooted in the needs of the believers.

\section{Place, Space, and the Sacred}

The contributions in this volume are based on the presupposition that "place" and "space" form neither mere containers nor contexts for human action. Rather, space and human action are interwoven; just as human action produces and changes space, space structures and limits human action. Multi-religious sites are not only points of intersection in space and time where different religious dimensions have survived; they are also places in which social and religious struggles take shape or are contained, thus negotiating the meaning and limits of multi-religiosity. A closer look at the possibly ambivalent character of sacred places throws new light on one of the most prominent issues in the studies of religion, the relation between the "place" and the "sacred." According to the historian of religion Mircea Eliade (1907-1986), the sacred place is sharply distinct from its profane counterpart and forms the solid centre of the world (axis mundi), to which the believers' bodies, hearts, and minds are oriented (Eliade 2008, 23-62). In such a place, the sacred breaks through, appears in the profane, and becomes what Eliade calls "hierophany;" such a manifestation of the sacred suspends the relativity of profane place and allows human communication with the sacred.

New approaches in the study of religions question Eliade's sharp distinction between the sacred and the profane and are more interested in the "human processes" that contribute to the sacralisation of space. While Eliade's understanding is one-dimensional, social constructivism stipulates that nothing is inherently sacred. Accordingly, human actions constitute one place as profane and another as sacred. 
The question is how the inventors, architects, holders, and adherents of sacred places ascribe and inscribe meaning to places (Knott 2005a, 2005b, 2009). Place is produced, claimed, and negotiated by groups with specific interests; in the words of Jonathan $Z$. Smith $(1987,28)$, "Human beings are not placed, they bring place into being." Such constructivist approaches pay particular attention to rituals and practices that sacralise and politicize places and mark them as neither exchangeable nor negotiable. These approaches look beyond locally rooted, clearly marked, mono-religious sacred "places" and move on to "spaces," which are understood as more open, fluid, and dynamic. They add not only a diachronic and synchronic extension in time and space to sacred places, but also stress the physical, social, and symbolic dynamism in which these places are embedded. Political power shifts, while religious struggles over meaning and social mobility affect sacred places. Therefore, the structure, shape, use, and perception of sacred places not only reflect their religious dimension but also interact with changes in the political, social, and symbolic landscape. According to these scholarly approaches, sacred places are framed as ever changing, similar to religions, which are also not seen as fixed sets of elements but as an ever-evolving web of meanings, signs, and images. In this context, the scope of sacred places that are studied has also expanded; beyond official religious sites, attention is payed to unofficial places of worship in which religious practices take place (Knott 2005a, 2005b, 2009).

Against this background, the discussion on the multi-religious dimension of sacred places increases the focus on the constructed character of holy places because holiness, in a multi-religious context, is open to multi-dimensional meanings. The practices at multi-religious sites often show a dialectic between social openness and boundedness. The common use of sacred places often goes hand in hand with a porosity of boundaries and a re-erection of demarcations. In this respect, multireligious places show different degrees of interaction, regulation, competition, and contestation, partly depending on whether they are isolated shrines in rural areas or parts of sacral or non-religious building complexes in urban centres.

For mixed religious practices, a marginal location is often, but not always, characteristic because many of these practices take place on the margins of religious institutions or outside spaces that are directly controlled and overseen by the authorities, which may frown at certain practices that bring together and mix believers from different confessions or religions (Albera 2008). The local sharing of sacred places often does not follow top-down policies but is embedded in everyday experiences in which the religious Other is the neighbour (Bowman 2012). Not only places, but also saints and rituals can be shared and bear different layers of meaning. Looking at mixed religious practices on the margins leads to understanding religion beyond institutionbased constraints, closer to the ground, to the individual practitioners and their local 
identities. However, it would be wrong to see all cases of religiously "shared" places as examples of blurring boundaries or subversive acts directed against the authorities. If we bring in religious and political authorities beyond the local level, we discover that their roles differ widely. Sometimes they try to purge places of the religious Other; sometimes they are neutral or open to diversity; sometimes they support or even impose multi-religious practices (Weltecke 2012). Often enough, rulers exploit or even stage multi-religious practices in order to legitimatize their rule; if political fortunes change, multi-religious presentations can be discredited, may fall into oblivion, and can be supressed (ibid.).

In spite of the "spatial turn" in the academic discussion of place, the differences between place and space should not be blurred. Sociologist Thomas Gieryn (2000), pleading for "a space for place in sociology", names three defining features of placelocation, material form, and meaningfulness - that distinguish it from the surrounding, more inclusive and abstract space. Thus, inter-religiously shared place and multireligious space are different categories and must be kept distinct. Neither can multireligious space be reduced to examples of shared sites, nor do shared places symbolize a multi-religious landscape. Instead, a shared place represents a special arrangement for the direct encounter of different people, whereas multi-religious space can include different places, various arrangements, and contradictory behaviour. Although shared sacred places and multi-religious space are inter-connected in various ways, transformations on one of the two spatial levels often affect the other only indirectly. All contributions in this volume-although taking different examples as starting points and drawing on different theoretical approaches-highlight this difference between place and space as well as the pertinacity of the local versus the global.

Different religious groups not only share places simultaneously; sometimes, sharing is a serial and involuntary act. Since Late Antiquity, the de-sacralisation of temples, churches, mosques, and synagogues has concurred with the sacralisation of these buildings by new owners. Such cases of consecutive use are often controversialvisible, for instance, in the conversion of the Mesquita-Cathedral in Cordoba, the cathedral Santa María de la Sede with the Giralda in Seville (a former Almohad mosque), the Hagia Sophia in Istanbul, and in the destruction of the Babri Masjid in Ayodhya in 1992. A less prominent example is the Ibn Shushan Synagogue in Toledo. Built in the twelfth century in white colour and Moorish style influenced by Byzantine architecture, it was turned into a monastery named Santa María la Blanca after the Reconquista in the fifteenth century. Although a national memorial site and a museum still in the possession of the Catholic Church, it is no longer in religious use but has become an armoury of a company which produces bullfight swords. In 2013, more than 600 years after its conversion, the President of Jewish Communities in Spain made a 
request, unsuccessful as of yet, to return the building to its original owners. Though desacralized, the location is not like any other place but has somehow retained traces of its former sacred aura that, though absent, can be restored (given the request). In this case, sacredness connects past, present, and future; it stems, on the one hand, from the Jewish awareness that the location has a sacred history and, on the other hand, from the potentiality that it can be re-made sacred by human action-by returning it to its "original" use.

In his study of the conversion of 50 mosques to churches on the Iberian Peninsula after the so-called Reconquista, Arera-Rütnek (2017) distinguishes different steps of the transformation process that became increasingly systematized in the course of time. Often, Muslims were allowed to use the mosque for some years after the Christian conquest of a given town between the eleventh to the fifteenth centuries; then, sometimes as a reaction to Muslim uprisings, the Christians adopted, slowly transformed, and consecrated the mosque and thus officially turned it into a church. The phase of what Arera-Rütnek (2017, 22-59) calls "acculturation" introduced a new spatial organisation of the interior as well as the establishment of an altar and other symbols. While "acculturation" was accomplished by minor changes to the building, like turning the minaret into a bell tower with a cross on top, the further transformation process consisted of large-scale structural interventions which in some cases began as late as 100 to 300 years after the conquest (ibid., 58, 148-152). These interventions changed the shape and appearance of the whole complex by the introduction of a choir, chapels, and a church nave as well as through the modification of the former mosque courtyard (șahn) and the reconstruction of the bell tower. Sometimes, these works led to a completely new building after some centuries, so that it has become extremely difficult and sometimes even impossible to identify the original Islamic components. Curiously enough, however, many Iberian mosque complexes were built on the sites of early Christian churches.

Once a site has acquired holy status, its sanctity often adheres to it, "irrespective of political and religious vicissitudes," as Limor $(2007,219)$ states, remarking that "nowhere else, perhaps, is this rule more applicable than in the Holy Land." Over the past two thousand years, the country changed hands repeatedly. During the first millennium, it passed from Jewish to pagan rule, then became Christian and Muslim. In the second millennium, "it was successively Muslim, Christian, again Muslim, and finally Jewish" (ibid.). This development has not left sacred places untouched and has created tensions, especially in Jerusalem, which is sacred to all three religions. Several places in and around Jerusalem-most prominently the area of the Temple Mount-are venerated by members of more than one religion, yet, "only rarely has the sharing of traditions become a foundation for dialogue and amity," as Limor (ibid.) states. "For 
the most part, it has become a bone of contention; dialectically, in fact, the greater the similarity and the reciprocity, the greater the argument, rivalry, and competition, each group of believers straining to confirm its own exclusivity and prove its absolute right to the tradition and the holy place" (ibid.).

Beyond these examples, there are unproblematic, yet peculiar cases of consecutive sharing, such as the Brick Lane Mosque in London with its migration history. Founded in the eighteenth century as a Protestant church by Huguenots from France, it turned Methodist in the beginning of the nineteenth century and became a synagogue by the end of nineteenth century, when Jewish refugees from Russia and Eastern Europe populated the quarter. Finally, textile workers from Bangladesh bought and refurbished it and turned it into a mosque in the 1970s (Norwich 2011, chap. 53).

If we take a longue durée perspective, we find that sharing sacred places, although rather widespread, was and is unevenly distributed in different regions at different times. Put simply, one could say that from the fourth to the nineteenth centuries, the coexistence between Muslims, Jews, and Christians was more pronounced in the Southern and Eastern Mediterranean region than in Western Europe, because the Byzantine, Seljuk, and Ottoman Empires "were multi-confessional political constructs and were culturally less homogeneous than their Western counterparts" (Couroucli 2012, 2; c.f. Barkey 2014, 46-58). The overall picture only started to change during the nineteenth and twentieth centuries, when "traditions of mixing and sharing began to disappear" (Couroucli 2012, 3) as ideas of nationalism were imported and many nation-states attempted to build homogenous societies and were unwilling to organize religious pluralism (Barkan and Barkley 2014a, 3). Nationalist "efforts to impose a singular religious or ethnic order" (ibid.) resulted in various projects of homogenization "stretching from accommodation and assimilation to violence, expulsion, and genocide" (ibid.). Thus, a much-cited "culprit" for the politicization of religious difference is nineteenth-century nationalism, which often had a negative impact on religious sharing. In their contributions in this volume, Méropi Anastassiadou-Dumont, Stefan Rohdewald, Tanja Zimmermann, Glenn Bowman, and Dionigi Albera expose the impact of nationalism in different settings.

In contrast, Western European societies become less homogenous religiously and culturally since World War II, mainly because of migration and the influx of people from former colonies. On the one hand, the number of mixed neighbourhoods has grown in Western European cities; on the other, newcomers have often been placed on the margins, which is symbolically expressed by all the mosques that have been built in industrial zones. Yet again, this form of marginalization does not express insignificance. Quite on the contrary, the integration of Islam and Muslims into Western European societies has become a permanent topic of discussion. From Salman Rushdie's Satanic 
Verses in 1988/89 to the twelve caricatures of Muhammad in the Danish newspaper Jillands-Posten in 2005, Western European societies were also forced to rethink the meanings and limits of blasphemy and sacrilege.

Against this background, the use of the terms "sacred" and "holy" and their relation to "religious" and "profane" are by no means self-explanatory. Rather, these terms cover a complex and ambivalent field of meanings, especially if we talk about different, and internally differentiated, religions like Christianity, Judaism, and Islam. The ritual theorist Ronald L. Grimes $(2014,258)$ explains the appropriateness of the terminology in the following way:

Most of us intuitively understand that a synagogue, mosque, or a cathedral is in some sense sacred regardless of how Judaism, Islam, or Christianity theologically conceptualize space. If nothing else, such places are sacralised behaviourally. People comport themselves differently in them as they move from outside to inside or from front to back.

In this sense, ritual place is a location where the ritual occurs, but when the ritual stops, the place may either turn back into an ordinary place or remain extremely important. Although rituals are always placed, not all ritual spaces are connected to sacred places or remain permanently so. Some rituals lose their value if not performed in the right place or the right direction, while for other rituals space is merely incidental because the action matters, not its location. Yet even rituals that are directed to God or a transcendental force necessarily happen in a location. Therefore, "place matters even to people who adhere to creeds that say it doesn't" (Grimes 2014, 257).

Often the sacred character of a place becomes manifest more clearly by acts of de-sacralisation. Islamophobic attackers often use pork to express their rejection of everything Islamic and distribute it, for example, on building plots for mosques; although the mere act of deposing pork constitutes an act of swinishness, it would be far-fetched to consider it sacrilegious from an Islamic point of view. However, three people who attached bacon strips to the door handles of the Central Mosque in Edinburgh and threw some strips inside were sentenced to several months in prison in 2014 (BBC 2014). Although the attackers, the court, and the Muslim community certainly hold rather different understandings of sacredness, they shared the judgement that the intention of the attack was to symbolize an offensive, abusive act, in spite of the small damage it caused. 


\section{Early Examples of Sharing and Polemics}

Against the background of intolerant acts and discourses, a word about the history of inter-religious sharing seems in order. Elizabeth Fowden (1999), who specializes in the material cultural of the Eastern Mediterranean, mentions three sites-the oak of Mamre in Hebron, the Umayyad Mosque in Damascus, and a complex in Rușāfa-as early examples of shared holy places.

According to tradition, the oak of Mamre was seen as the place where Abraham built an altar for God and where Yahweh and two angels appeared to him and his wife Sarah. When the two offered hospitality to the three strangers, the visitors foretold Sarah's conception of a son. The ecclesiastical historian Sozomen (d. 450) described festivities in which not only Jews and Christians took part but also "the Phoenicians and the Arabians" (Fowden 1999, 127). By building a church 150 years before Sozomen's report, the Christians tried to monopolize the place but were not successful at that time (ibid., 128).

In Damascus, Christians and Muslims commonly used a monumental basilica, dedicated to St. John the Baptist and built on the site of a former temple of Jupiter as well as an Aramean temple, for more than 70 years (from 635 to $706 \mathrm{CE}$ ). According to Muslim historians al-Balādhurī (d. 892) and Ibn 'Asākir (d. 1176), the Umayyad caliph al-Walīd I commissioned the construction of a new mosque in 706, which took about a decade. Part of this appropriation was also the "discovery" of John the Baptist's head by the caliph in a subterranean chapel, "which became part of the foundational myth of the mosque" (ibid., 133).

The third example, the shrine of St. Sergius at Rușāfa, was the most celebrated Christian Arab pilgrimage destination of late antique Syria and Mesopotamia (ibid., 134). In the eighth century CE, architects built a mosque that shared the courtyard and its stoa with the city's main church, which housed the martyrium of St. Serigus" (ibid., 135). The architecture, combining the mosque with the church, not supplanting it, made the participation of Muslims in the cult of St. Sergius possible.

In these three examples, sharing the same place means the "maintenance of separateness" (ibid., 127) of ritual. Sharing was, however, not limited to sacred places, shrines, and buildings, but also applied to rituals and saints than can accommodate different layers of meanings. Scholar of Jewish religion Alexandra Cuffel (2005), citing thirteenth- to sixteenth-century reports, travelogues, and biographies, draws attention to Jewish, Christian, and Muslim women who were said to donate lamps, oil, candles, money, and food to the shrines of holy men and women as well as to pilgrims. In these reports, shared rituals between "Turks, Moors, and Christians" (ibid., 408) are mentioned for the Milk Grotto in Bethlehem and al-Mațariyya close to Cairo. Coming 
to the Milk Grotto, people of all faiths, especially expectant mothers, drink pulverized dust dissolved in water as a cure for barrenness and difficulties in childbirth or nursing. According to a tradition, a drop of milk of the nursing Mary fell on the floor and changed its colour to white. Al-Mațariyya is said to be the place where Mary, Joseph, and the Child stopped under a tree on their flight to Egypt; suddenly a spring of water sprung up. The eyewitnesses of festivities in this place mention women of different faiths bathing in the water and bathing their children.

Moreover, Muslim chroniclers since the eleventh century attest to common prayers and processions in times of disaster, such as earthquakes and drought; they give the impression that "the inclusion of all types of human beings seems to have been an essential part of the ceremonies" (Cuffel 2013, 127). Under Mamluk rule in Egypt and Syria, public prayers for rain (istisqā') were performed as state-sponsored intercessory processions to a holy place, including the participation of the caliph, "the chief qãdī on foot among masses of students, poor and Sufis" as well as "the Jews and the Christians with their scriptures" (ibid., 126), according to a source of $1450 \mathrm{CE}$. A report from the late fourteenth century about a prayer procession outside of Damascus mentions that "the ritual begins with the Muslim people's fast, prayer at the mosque, a special gathering, and prayers at night" (ibid., 127), and when the Muslims leave the mosque, "Jews, Samaritans, and Christians join their Muslim neighbours, praying with them" (ibid.).

A prominent figure among shared saints is Khidr, "who is identified in the Muslim tradition as the unnamed companion of Moses who holds the secret to immortal life (Qur'an 18:60)" (Barkey 2014, 50). He is "often confused (or fused)" (Fowden 1999, 133) with the Christian saints Sergius and George and also venerated by Șūfīs, Zoroastrians, Yazidis, Alevis, and Alawites. In folk religion, Saint George and Khidr are both understood as dragon-slaying saint heroes, while the Islamic tradition also knows that Khidr and the Prophet Elijah meet every year (for more, see Franke 2000). The mixture of these figures is connected to a spring festival called Hidrellez, which is not only widespread from Anatolia over the Balkans to Crimean Tatars, but was also recognized as a feast day in the official contract between the city-state of Hamburg and the Alevi community in 2012. In this volume, Méropi Anastassiadou-Dumont comes back to the fascinating figure of Khidr and Hıdrellez in her discussion of holy places in Istanbul.

Sharing places, rites, and saints was also accompanied by religious polemics, prejudices, and imaginary tales, which shows once again that inter-religious practices went hand in hand both with communality and demarcation. In fact, our knowledge about cross-religious and cross-confessional practices in the distant past stems, to some degree, from polemics written by religious scholars who frown upon such practices or oppose them. Because the pilgrimage to shrines, the veneration of 
holy women and men, and prayers for healing or help in existential situations were often associated with women's pious activities and cross-faith sociability in all three traditions, scholars have described them as folk and women's religion. Theological polemicists often argued against the mixing of both religions and gender. As Cuffel (2005) shows, some Muslim scholars explicitly associated women's visible participation in such circumstances with non-Muslim practices, innovation (bida'), and immorality; thus, they also tried to shame their male co-religionists and stimulate them to behave "manly." Several Muslim scholars, like Ibn Taymiyya (d. 1328) and Ibn al-Hajj (d. 1336), abhorred that Muslim women bathed their children together with non-Muslim women at Mațariyya, which would allow non-Muslim women to look at the body of a Muslim woman-a "scandalous matter" these scholars declared forbidden (ibid., 410). Even scholars who defended the practices of visiting saints' shrines "felt obliged to address women's participation as a separate issue" (ibid., 412) and contrasted "the masculine ideal of knowledge and control...to women's emotionalism" (ibid., 413), thus denigrating but not condemning such customs. For European Christian and Jewish authors, the participation of women was secondary; their polemics were directed more at the blurring of religious boundaries than at gender difference. An example that unites the blurring of religious boundaries with a polemic undertone is the story-told by the Jewish rabbi and traveller Moses b. Mordechai Bassola (d. 1560)_about a Muslim woman who wanted to pick almonds from a tree on a Jewish saint's grave without asking permission from the saint, against the advice of another woman (Cuffel 2005, 407f.). The woman fell from the tree and broke all of her limbs "until she dedicated the gold that was on her hand" (ibid., 408). After that, other trees were also dedicated, and sixty years after the Muslim woman's act, a field of four hundred olive trees "sacred to the saint" (ibid.) had resulted from her accident.

The real or imagined Jewish and Muslim veneration of the Virgin Mary was a source of wonder and a rhetorical weapon for Christian authors of the twelfth and thirteenth centuries (Cuffel 2003, 37). In various tales, polemicists underlined their supremacy of Christianity in different ways, depending on whether they judged Muslim or Jewish encounters with Mary or whether the Christian authors were located in areas of Europe where Muslims and Jews were relatively near or relatively distant (ibid., 37). Generally, "the Virgin Mary fought and won her own battles with the Muslims not with argumentation or swords, but with miracles" (ibid., 40). Often, these stories portray Mary as willing to assist Muslims and help them in spite of their opposition to Christianity (ibid., 41). The difference is that "in most stories originating from Latin Europe, such encounters almost invariably resulted in the Muslims' conversion to Christianity" (ibid., 42) as soon as the Muslims admitted their love of the Virgin. In Christian narrations from the Eastern Mediterranean, similar plots do not result in the Muslims' conversion. 
Mary's miraculous interventions on behalf of Muslims were rather seen as a fulfilment of the prophecy that "all generations shall call me blessed" (Luke 1: 48). Thus, the Muslims' and "sinners'" veneration of Mary gained importance because of their status as outsiders to Christianity.

The Christian stories about Jewish encounters with Mary developed against a different backdrop, since Mary does not appear in the Jewish scriptures and is depicted as a figure doomed to give birth to a false messiah in medieval extra-biblical writings. As the Christian stories can thus be read as a reaction to the Jews' well known and "longstanding rejection of Christianity" (ibid., 58), Jews only have the choice between conversion, death, and condemnation to hell. The stories, in which Mary intervenes and takes revenge against recalcitrant Jews, easily outnumber similar stories with Muslims: "That Jews regularly needed Mary despite their vehement rejection of her was perhaps the strongest demonstration of Christianity's power" (ibid., 59).

\section{Non-Sharing as Part of Inter-Faith Practices}

Cross-faith polemics, prejudices, nationalist imaginaries, and the model of "antagonistic tolerance" can nurse doubts as to the degree to which inter-religious sharing is possible. Yet, the framing of (peaceful) practices of sharing versus the (violent) tendency of nonsharing along the lines of Hayden's (2002) argumentation not only rests on a dichotomy but also on one that is false.

In a recently edited volume, Darieva et al. (2018, 9f.) have drawn attention to the fact that the assumption that non-sharing "equals hostility or...hinders friendly coexistence" is not necessarily correct; nor does cohabitation "necessarily lead to sharing, collaboration or religious mixing." Drawing on earlier research (Weiner 1992; Hauschild 2003, 2008), the anthropologist Florian Mühlfried (2018, 151f.) stresses that preventing objects from free circulation or restricting access to shrines "may well form the backbone of economically and socially interacting with other people." By arguing against the anthropological "fetish of connectivity" (Pedersen 2013), Mühlfried (ibid., 152) holds that the non-sharing of practices, places, or objects can discharge potential tensions in society and "may contribute to good social relations by avoiding conflicts and sustaining autonomy." Thus, not sharing can create "cultural reserves" that are withdrawn not only from general use but also from contestation and commodification; these "cultural reserves" can minimize risks for minorities and enhance their potential of belonging to society. In this sense, Mühlfried argues that the small Jewish community of Racha in Georgia developed a sense of belonging to place and society by not sharing Christian or Georgian sacred sites. In the joint history of the Jewish and Christian 
population of Racha, a shared sense of mutual understanding and conviviality "goes alongside a strict division of sacred spaces," Mühlfried (ibid.) argues. By not sharing places with the majority, Georgian Jews could not and did not make claims to the majority's territory, while they preserved their own; the Christian majority in turn protected the Jewish synagogue against destruction in Soviet times, when they were unable to save their churches which were considered symbols of the ancient regime. "It has been precisely this religious difference, manifested in landscape, which fostered a friendly mode of coexistence" (ibid., 169).

While Mühlfried interprets the act of "not sharing the sacred" as a "cultural reserve," Silvia Serrano (2018) draws attention to a different example of nonsharing - a multi-religious complex whose mode of existence is based on "sharing the not-sacred." Inaugurated in 2012, the complex, known as Rabati in Southern Georgia, bordering Turkey, consists of a mosque, a madrasa, an Orthodox church, a Romantic pavilion, as well as boutiques, restaurants, and a hotel. Nearby, there are also Turkish baths, two synagogues, and an Armenian and a Catholic church. The state-sponsored restoration-the only one including non-Orthodox religious buildings in Georgia-is designed to represent the living history of the religiously diverse border region of Georgian and is meant to attract international tourists to a "symbol of tolerance," according to self-promotion which draws on a pluralistic and multicultural vision of Georgia (ibid., 212). This celebration of multi-culturalism is achieved by a de-sacralisation of the cultural heritage, "by banning religious practice in all the sites located in Rabati" (ibid., 215). Thus, the state implicitly reinforces the idea that coexistence of various religions favours conflict and that there would be conflicts if the mosque were opened for worship. Although the restoration of the mosque was deemed necessary, it was not even possible to set up a crescent. Any criticism by Turkish diplomats regarding changes introduced to the original architecture were considered an illegitimate intervention of a foreign power. Thus, the mosque was deprived of its local history and Georgian characteristics and turned into "a generic Islamic building" with elements from the Moorish architecture of the Alhambra and the Dome of Rock in Jerusalem. The dome of the mosque has been gilded to symbolize a "New Jerusalem"with a mosque, a church, and a synagogue side by side (ibid., 220). Yet, the presence of Muslims and Jews in the discourse of multi-culturalism contrasts with their absence in the town (ibid.). Though representing a multi-religious site, Rabati's version of Disneyland is certainly no place of sharing the sacred.

The anthropologist Will Tuladhar-Douglas (2012) has drawn attention to another facet of non-sharing: the case of the non-participation of resident Tibetans in a procession that ideally unites all communities in the Nepalese town of Pharping in the Kathmandu valley. The Newars, the indigenous population of the valley, who 
have achieved a complex synthesis of Buddhism and Hinduism, annually organize a procession of Vajrayoginī, the image of a Tantric Buddhist female Buddha, from her shrine to the town. The procession has a tradition of more than one thousand years and draws the residents of Pharping together for a festival lasting three days (ibid., 65). As the event ideally invites all members of local religions to celebrate a Pharping identity, the refusal of the so-called Tibetan Buddhists, who perceive the procession as a Hindu ritual, puts to test the strategies of a mixed community to cope with diversity without exclusion. Tuladhar-Douglas (2012) explains this non-participation as a "complementary process" (ibid., 62) in a region where intercommunal collaboration in ritual life is a rule and "worshippers collude in ignoring potentially divisive behaviour." Although Tibetan Buddhists opt out, the Pharpings, who practice inclusivism, tend to overlook or deny this fact in order to sustain a social fabric that is based on disavowing exclusivist behaviour (ibid., 73).

An example similar to Mühlfried's study of Georgian Jews, yet with another nuance of non-sharing, is Robert Langer's (2008) inventory of Zoroastrian shrines in modern Iran. As the vast majority of the one hundred shrines that Langer has documented is not shared, they appear to be a "cultural reserve" in Mühlfried's sense. However, Langer also found one shared Zoroastrian-Muslim shrine (ibid., 462-467) and one ZoroastrianJewish twin shrine (ibid., 637-640). On the one hand, he interprets these two shrines as left over from a long history of interaction and sharing (ibid., 180-196); on the other hand, it is clear that the vast majority of shrines are not-or no longer-shared sacred places. Thus, we can firstly conclude that there are exceptions to the rule, in this case to not sharing. Secondly, even the mere existence of so many shrines after approximately 1,400 years of Muslim rule expresses a form of cohabitation that contributes to a multireligious landscape extending well beyond the main Zoroastrian settlement areas in Iran. Before Langer's inventory, the maximum number of Zoroastrian shrines in Iran had been estimated at 25 (Langer 2008, 48). His field research has not only disproved this estimation, but has also shown the wide range of Zoroastrian sites, from private shrines to veritable pilgrimage centres.

\section{This Volume: Changing Practices, Changing Landscapes}

As especially the last examples of partial non-sharing in multi-religious settings show, multi-faith encounters cannot be reduced to a narrow understanding of sharing the sacred or a dichotomy between sharing and non-sharing. They include asymmetrical relations as well as forms of non-sharing, and they can comprise ideals of inclusivism, 
deviating practices, and conflicting claims. The examples of prayer rooms in nonreligious environments; the long history of shared sites, practices, and polemics; the consecutive sharing of buildings between different faiths; and the cross-religious veneration of saintly figures-all of these phenomena open up a variety of perspectives on multi-faith encounters and spatial arrangements that exceed the dichotomy of sharing and not sharing. They hint at the long historical trajectories of holy sites, their embeddedness in changing multi-religious landscapes, and the multiplicity of multifaith practices. Therefore, these examples not only bind together the distant past with contemporary concerns but also show that the actors of inter-faith encounters may share or not share and differently interpret, ignore, or lay exclusive claim to what they believe is sacred.

Against the background of this vibrant field of research, the present special issue of Entangled Religions has emerged from a conference about "Shared Sacred Places and Multi-Religious Space" that took place at the Leibniz Institute of European History (IEG) in Mainz in September 2016. As the title of the conference indicates, a main interest was to re-think the relation between place and space and between different religions. The conference took place in the framework of the IEG focus topic "Europe from the Margins," which also included a lecture series on processes of marginalization and exclusion with regard to social and religious minorities within and beyond Europe. This background explains the range of topics in this special issue to a certain degree, because the conference had the aim to de-centre established notions of Europe and religion and understand them in their multi-dimensionality. While cross-faith practices are a worldwide phenomenon, the main geographical focus of the following articles is on southeastern Europe and the Mediterranean with their spatial extensions to Asia. Proceeding from here, the contributions in this volume understand multi-faith practices as embedded in local arrangements as well as in larger multi-religious landscapes, thus taking account of the interconnection between the local and the global and paying attention to the micro and macro levels of analysis.

Méropi Anastassiadou-Dumont raises a topic not present so far in the canon of research literature on sacred places and pilgrimage-formerly Christian places in the wider Constantinople/Istanbul region increasingly taken over by (nominal) Muslims since the second half of the twentieth century. In her contribution "Sacred Spaces in a Holy City. Crossing Religious Boundaries in Istanbul at the Turn of the Twenty-First Century," she suggests that shared cults must have existed for some time, although the literature of the nineteenth and early twentieth centuries lacks such information for various reasons. She then draws attention to the Greek word ayazma that is used in Turkish to name holy water sources and notes that today, the ayazmas, which were a Greek Orthodox specificity in Istanbul, attract mainly Muslim pilgrims, while Greeks 
tend to abstain from showing up with "others." The most famous Muslim pilgrimage to a Christian ayazma, taking place every year, leads to the Byzantine monastery of St. George Koudounas in Büyükada (the Princes Island). Although Orthodox presence was very strong before the 1990s, Greek absence is also visible in several other places, as Anastassiadou-Dumont shows. Her explanation is that the interreligious field remains highly fluctuating and that, although the Turkish state desires, organizes, and controls interreligious sharing, the demographic shift and political developments may have a different effect.

In his contribution "A Muslim Holy Man to Convert Christians in a Transottoman Setting: Approaches to Sarı Saltuk from the Late Middle Ages to the Present," Stefan Rohdewald wonders to what degree Sarı Saltuk, a legendary warrior-saint assumed to have died in 1297/98, really represents an inter-religious figure. Although held in high esteem by the Bektashi Order and claimed by Christians as St. Spyridon, St. Nicholas, or St. Naum, the available sources rather point at conflicting claims and interpretations than at inter-religious veneration that moreover seems to have steadily decreased over the centuries, if it ever existed. Sifting through the hagiographic literature, Rohdewald stresses the high mobility that was accredited to this warrior-saint, who presumably wandered from Arabia over Anatolia and the Balkans to Gdansk. Even after his departure, this mobility was not interrupted, as seven coffins, Sarı Saltuk's body in each of them, were sent out to the Kings of Moscow, Poland, Bohemia, Sweden, Adrianople, and Moldova as well as to the ruler of Dobruca, all of whom had asked for his remains. Since a wide extension of Sarı Saltuk's area of action beyond the borders of the Ottoman Empire can be observed especially since the seventeenth century, Rohdewald doubts whether the figure and its sanctuaries can be understood as transreligious phenomena, instead underlining their trans-regional and trans-Ottoman character. As Sarı Saltuk's ante and post mortem mobility covered the Ottoman Empire, Poland-Lithuania, Muscovy, and the Crimean Khanate, it described a region "intertwined through extensive, mutually claimed borderlands." Thus, Sarı Saltuk's inter-religiosity seems to represent a case in which a figure is venerated "commonly," but not "in common," as Glenn Bowman succinctly puts in his contribution.

In "Spirit of Place and Nation Building: Kosovo and Bosnia from Imperial to PostCommunist Times," Tanja Zimmermann compares the spirit of place, the genius loci, of the Serbian and the Bosnian legend of origin and its meaning for nation building. The Serbian nationalist narrative reactivates the legend of the Serbian defeat against the Ottomans in the Battle of Kosovo on "the Field of Blackbirds" (Kosovo polje) in 1389. This event was recounted not only by local actors but also by European travellers, artists, and architects in the course of nation building in the nineteenth century. The legend turned into a "natural" Serbian myth and was embodied by Gazimestan, the memorial 
place at the core of the Field of Blackbirds, where a memorial tower was erected in 1953. As this place has belonged to the autonomous Republic of Kosovo since 2008, the memorial today is "fenced and monitored by cameras, to prevent it from being destroyed by Albanians." The foundation myth for a Bosnian nation lacked a similar location. As Bosnia became a Habsburg protectorate after 1878, the Austro-Hungarian project aimed at creating common ground for Muslims, Jews, Catholics, and Orthodox Christians by focusing on the pre-Ottoman Bogomils, who surrendered neither to Rome nor to Constantinople and followed Manichaeism in spite of Christendom, but later turned to Islam. Lacking a spirit of place, the National Museum in Sarajevo, founded in 1888 , collected traces from the past in a scientific manner. "In the garden, a large collection of Bogomilian grave steles (stećci), brought from different scattered places in Bosnia, was displayed." In Yugoslavia of the communist era, after the break with the UdSSR, the Bogomils were also presented as predecessors of Tito's "third way" beyond Soviet communism and Western capitalism. However, Zimmermann's comparison between the two myths shows that the Bogomil legend was doomed to fail because it lacked a location and thus the spirit of place, whereas the rivalling Serbian myth was based on a strong genius loci.

In his article "Shared Shrines and the Discourse of Clashing Civilisations," Glenn Bowman sums up his long experience, thirty-five years of research, with Muslim-Christian cohabitation at various places and in different regions. He outlines the possibilities and limits of sharing the sacred against the background of wider intellectual and political developments that favour "groupism" and "identitarianism" and often tend to exclude Muslims. Discussing three different case studies of MuslimChristian sharing - the Monastery of Sveti Bogoroditsa Prechista near Kicevo, North Macedonia; the Church of the Holy Sepulchre in Jerusalem; and the site of Sveti Nikola/ Hadir Bābā in Makedonski Brod, North Macedonia-, he highlights the differences between these places. Bowman argues that the difference between place and space is key to understanding the emergence of antagonism in shared sites. Place forms a site of inhabitance and concrete interaction, while space can hold different entities that have no relation. When different groups share a place, they are forced to accommodate to each other's presence. When, however, two or more communities try to construct and inhabit place exclusively, accommodation becomes impossible. When places are transformed into exclusive properties, sharing and mixing turn contentious and any conflict can be read as a sign of a wider irresolvable antagonism. For Bowman, then, the discursive framing-exemplified by the "clash of civilisations" discourse-is a main point that transforms shared sites into arenas of struggle.

In "Digressions on Polytropy: An Exploration of Religious Eclecticism in Eurasia," Dionigi Albera employs the concept of "polytropy" that has been introduced by 
anthropologist Michael B. Carrithers in the field of the study of religion. As scholars generally accept that polytropic forms of religious life are widespread in South Asia, Albera discusses various examples of religious eclecticism and fluidity in China, India, and Japan and argues that Christians and Muslims in Asia also show polytropic forms of worship. Therefore, he sees no reason not to transfer the notion of polytropy to the Mediterranean region as well, in which monotheistic beliefs dominate. Drawing on the manifold studies on religious sharing, he argues that "Mediterranean religious pluralism seems to produce effects comparable to those observed in Asia." Arguing against the "religious congruence fallacy" that assumes that an individual's religious beliefs, attitudes, and behaviour are congruent and stable, Albera proposes to generally rethink religious diversity along the differentiation between polytropy-in the sense of multiplicity and versatility-and monotropy-in the sense of unity and uniformity. While polytropic tendencies are constitutive elements of religiosity, monotropic propensities occupy the centre of the stage in any religious traditions and assure the continuity and stability of any religious tradition. However, these concepts do not describe absolute fixities but tendencies, since "the religious specialists, who are the main bearers of the religious system, may often accommodate lay people's polytropic trends, which they accept and also encourage, even if they do not personally adhere to these forms of religiosity." The concept of "polytropy" can help us to better grasp the practical modality of doing religion, although-or because- "monotropic" tendencies hold a hegemonic position in the religious landscapes of the so-called "world religions," according to Albera.

Manfred Sing deals with the places and spaces ascribed to Islam in two interrelated contributions. In "Where Do the Multi-Religious Origins of Islam Lie? A Topological Approach to a Wicked Problem," he critically analyses the academic debate about the location of the origins of Islam. In the last few decades, revisionist scholarship has increasingly cast doubt on Mecca as the birthplace of Islam and attempted to relocate the origins of Islam to the North of the Arabian Peninsula. A relocation would better explain the manifold hints at Biblical material in the Qur'ān and the minor role of pre-Islamic Mecca. Mainstream scholarship, however, clings to the differentiation between Meccan and Medinan revelations, although the Qur'ān rarely mentions any places. Sing takes both revisionist and traditional scholarship to task when he proposes to understand the social and historical production of Mecca as a gradual process intertwined with the emergence of Islam. He also holds that the treatment of various pagan, Jewish, Christian, and other religious elements in the Qur'ān and early Islam is connected to the religious diversity that is characteristic for Islam as well as for the landscapes in which Islam emerged. This argument forms the bridge to the second article, "Towards a Multi-Religious Topology of Islam: The Global Circulation 
of a Mutable Mobile," in which Sing argues that it is impossible to understand the history of Islam without considering its internal and external diversity. Therefore, he proposes the concept of a multi-religious topology for the study of Islam. Drawing on the discussion about the spatial turn in the humanities, he argues that it is necessary to distinguish between the argument that our ideas about space are socially produced and the argument that space is socially produced. Thus, he critically revisits different academic ways through which Islam is inscribed onto space and history, and argues that approaches that speak of "Islamic space" homogenize Muslims and obliterate nonMuslim peoples. In response, he argues that from early on, Islam was located in a transreligious and transcultural space in which ideas about Islam circulated, took shape and were discarded. Sing shows how Muslim and non-Muslim scholars discussed common reference points-the role of Sufis, Jews, and Christians under Muslim rule-and how arguments about Islam also informed European debates about religious tolerance, the treatment of Native Americans, and the abolishment of slavery. The manifold interconnections created a common space for both "Europe" and "Islam," although they were mostly conceptualized as antagonistic entities.

\section{Acknowledgments}

I thank the Leibniz Institute of European History in Mainz for funding the conference on "Shared Sacred Places and Multi-Religious Space" in 2016 that brought together researchers with different disciplinary backgrounds. The idea for the present volume goes back to the insights, challenges, and perspectives discussed during three days of fruitful scholarly exchange. I am grateful to the anonymous reviewers, whose critical comments helped much to improve the volume as a whole as well as the individual articles. Special thanks goes to Julia Reiker and Maren Freudenberg for carefully copyediting all articles in this special issue of Entangled Religions.

\section{Literature}

Albera, Dionigi. 2008. “'Why Are You Mixing what Cannot be Mixed?' Shared Devotions in the Monotheisms." History and Anthropology 19 (1): 37-59.

Albera, Dionigi, and Maria Couroucli, eds. 2012. Sharing Sacred Spaces in the Mediterranean: Christians, Muslims, and Jews at Shrines and Sanctuaries. Bloomington: Indiana University Press. 
Arera-Rütnek, Tobias. 2017. Transformation von Moscheen zu Kirchen auf der Iberischen Halbinsel. Petersberg: Micheal Imhof Verlag.

Augé, Marc. 1995. Non-Places. Introduction to an Anthropology of Supermodernity. London: Verso.

Barkan, Elazar, and Karen Barkey. 2014a. "Introduction." In Barkan and Barkey 2014b, 1-31.

_- - ed. 2014b. Choreograhies of Shared Sacred Sites. Religion, Politics, and Conflict Resolution. New York: Columbia University Press.

Barkey, Karen. 2014. "Religious Pluralism, Shared Sacred Sites, and the Ottoman Empire." In Barkan and Barkey 2014b, 33-65.

BBC. 2014. "Pair Jailed for Edinburgh's Central Mosque Bacon Attack." June 20, 2014. https://www.bbc.com/news/uk-scotland-edinburgh-east-fife-27941589.

Beinhauer-Köhler, Bärbel, and Christian Meyer. 2015. “In Bewegung. Gebetsräume für Juden, Christen und Muslime am Frankfurter Flughafen.“ In Beinhauer-Köhler, Roth, and Schwarz-Boenneke 2015, 195-212.

Beinhauer-Köhler, Bärbel, Mirko Roth, and Bernadette Schwarz-Boenneke, ed. 2015. Viele Religionen - ein Raum?! Analysen, Diskussionen und Konzepte. Berlin: Frank \& Timme.

Bowman, Glenn. 2002. "Comments." Current Anthropology 43 (2): 219-220.

- - , ed. 2012. Sharing the Sacra. The Politics and Pragmatics of Intercommunal Relations around Holy Places. New York: Berghahn Books.

Bryer, Anthony. 1979. "The Late Byzantine Monastery in Town and Countryside." Studies in Church History 16: 219-241.

Couroucli, Maria. 2012. "Sharing Saced Places - A Mediterranean Tradition." In Albera and Couroucli 2012, 1-9.

Cuffel, Alexandra. 2003. “'Henceforward all generations will call me blessed': Medieval Christian Tales of Non-Christian Marian Veneration." Mediterranean Studies 12: 37-60.

- - . 2005. "From Practice to Polemic: Shared Saints and Festivals as 'Women's Religion' in the Medieval Mediterranean." Bulletin of the School of Oriental and African Studies 68 (3): 401-419.

- - . 2013. "Environmental Disasters and Political Dominance in Shared Festivals and Intercessions among Medieval Muslims, Christians, and Jews." In Muslims and Others in Sacred Space, edited by Margaret Cormack, 108-146. Oxford: Oxford University Press.

Darieva, Tsypylma, Thede Kahl, and Svetoslava Toncheva, eds. 2017. Sakralität und Mobilität im Kaukasus und in Südosteuropa. Wien: Verlag der Österreichischen Akademie der Wissenschaften. 
Darieva, Tsypylma, Florian Mühlfried, and Kevin Tuite, eds. 2018. Sacred Places, Emerging Spaces. Religious Pluralism in the Post-Soviet Caucasus. New York: Berghahn Books.

Eliade, Mircea. (1959) 2008. Das Heilige und das Profane: Vom Wesen des Religiösen. Köln: Anaconda.

Fowden, Elizabeth Key. 1999. "Sharing Holy Places." Common Knowledge 8 (1): 124146.

Franke, Patrick. 2000. Begegnung mit Khidr. Quellenstudien zum Imaginären im traditionellen Islam. Stuttgart: Franz Steiner Verlag.

Gieryn, Thomas F. 2000. "A Space for Place in Sociology." Annual Review of Sociology 26: 463-496.

Groß, Gisela. 2000. “Multireligiöse Räume." Kunst und Kirche 63 (2): 66-71.

Grimes, Ronald L. 2014. The Craft of Ritual Studies. Oxford: Oxford University Press.

Hauck-Hieronimi, Gerda. 2015. “Acht Weltreligionen-ein Dach-ein gemeinsamer Betrieb. Haus der Religionen-Dialog der Kulturen in Bern." In BeinhauerKöhler, Roth, and Schwarz-Boenneke 2015, 163-175.

Hasluck, Frederick W. 1929. Christianity and Islam under the Sultans, 2 vols, edited by Margaret M. Hasluck. Oxford: Oxford University Press.

Harris, Jonathan, Catherine Holmes, and Eugenia Russell, eds. 2012. Byzantines, Latins, and Turks in the Eastern Mediterranean World after 1150. Oxford: At the Clarendon Press.

Hauschild, Thomas. 2003. Magie und Macht in Italien: Über Frauenzauber, Kirche und Politik. Gifkendorf: Merlin-Verlag.

-_-. 2008. Ritual und Gewalt. Frankfurt am Main: Suhrkamp.

Hayden, Robert M. 2002. "Antagonistic Tolerance. Competitive Sharing of Religious Sites in South Asia and the Balkans." Current Anthropology 43 (2): 205-219.

- - . 2015. "Intersecting Religioscapes in Post-Ottoman Spaces: Trajectories of Change, Competition and Sharing of Religious Spaces." In Shared Spaces and their Dissolution: Practices of Coexistence in Cyprus and Elsewhere, edited by Rebecca Bryant, 59-85. New York and Oxford: Berghahn.

Hayden, Robert, Tuğba Tanyeri-Erdemir, Timothy D. Walker, Aykan Erdemir, Devika Rangachari, Manuel Aguilar-Moreno, Enrique López-Hurtado, and Milica BakićHayden. 2016. Antagonistic Tolerance: Competitive Sharing of Religious Sites and Spaces". London: Routledge.

Huntington, Samuel P. 1996. The Clash of Civilizations and the Remaking of World Order. New York: Simon \& Schuster.

Jonas, Marin. 2008. “Interreligiöse Räume: Miteinander oder nebeneinander?” In Justnik and Feldhoffer 2008, 12-13. 
Justnik, Herbert. 2008. "Einleitung." In Justnik and Feldhoffer 2008, 7-8.

Justnik, Herbert, and Juliane Feldhoffer, eds. 2008. Places of Worship: Andreas Duscha. Interfaith prayer rooms at airports; Begleitbuch und Katalog zur Ausstellung im Österreichischen Museum für Volkskunde, 17.09.-16.11.2008. Wien: Metroverlag.

Kletke, Daniel. 2000. "Der Meditationsraum bei den Vereinten Nationen in New York." Kunst und Kirche 63 (2): 98-99.

Knott, Kim. 2005a. The Location of Religion: A Spatial Analysis. London: Equinox.

-_- 2005b. "Spatial Theory and Method for the Study of Religion." Temenos 41 (2): 153-184.

- - . 2009. "From Locality to Location and Back Again: A Spatial Journey in the Study of Religion." Religion 39 (2): 154-160.

Kölbl, Alois, and Andreas Duscha. 2010. “Interreligiöse Gebetsräume auf Flughäfen. Alois Kölbl im Gespräch mit Andreas Duscha." Kunst und Kirche 73 (2): 27-29.

Krstic, Tijana. 2013. “The Ambiguous Politics of 'Ambiguous Sanctuaries': F. Hasluck and Historiography on Syncretism and Conversion to Islam in $15^{\text {th }}$ and $16^{\text {th }}$ Century Ottoman Rumeli." In Archaeology, Anthropology and Heritage in the Balkans and Anatolia: The Life and Times of F.W. Hasluck, 1878-1920, vol. 3, edited by David Shankland, 247-262. Istanbul: The ISIS Press.

Kuschel, Karl-Josef. 2010. "Multireligiöse Andachtsräume - eine Problemanzeige. Theologische und interreligiöse Perspektiven." Kunst und Kirche 73 (2): 5-11.

Langer, Robert. 2008. Pīrān und Zeyāratgāh: Schreine und Wallfahrtsstätten der Zarathustrier im neuzeitlichen Iran. Leuven: Peeters.

Limor, Ora. 2007. "Sharing Sacred Space: Holy Places in Jerusalem between Christianity, Judaism and Islam." In In Laudem Hierosolymitani: Studies in Crusades and Medieval Culture in Honour of Benjamin Z. Kedar, edited by Iris Shagrir, Ronnie Ellenblum, and Jonathan Riley-Smith, 219-231. Aldershot: Ashgate.

Löffler, Klara, and Herbert Nikitsch. 2008. "Ein-/Blicke: Die interreligiösen Räume in München und Wien." In Justnik und Feldhoffer 2008, 14-16.

Mühlfried, Florian. 2018. "Not sharing the Sacra." In Darieva, Mühlfried, and Tuite, 2018, 150-176.

Nagel, Alexander-Kenneth. 2015. “Kontaktzone oder Spannungsfeld? Multireligiöse Räume in religionssoziologischer Perspektive." In Bärbel Beinhauer-Köhler, Roth, and Schwarz-Boenneke 2015 2015, 35-54.

Norwich, John J. 2011. A History of England in 100 Places. From Stonehenge to Gherkin. London: John Murray. 
Pedersen, Morten A. 2013. "The Fetish of Connectivity." In Objects and Materials. A Routledge Companion, edited by Penny Harvey et al., 197-207. London: Routledge.

Shankland, David, ed. 2013. Archaeology, Anthropology and Heritage in the Balkans and Anatolia: The Life and Times of F.W. Hasluck, 1878-1920, 3 vols. Istanbul: The ISIS Press.

Serrano, Silvia. 2018. "Sharing the Not-Sacred. Rabati and Displays of Multiculturalism." In Darieva, Mühlfried, and Tuite, 2018, 203-225.

Smith, Jonathan Z. 1987. To Take Place: Toward a Theory of Ritual. Chicago: University of Chicago Press.

Spiegel, Andreas. 2008. "Der unbeliebte Raum und Räume der Beliebigkeit." In Justnik and Feldhoffer 2008, 17-19.

Tuladhar-Douglas, Will. 2012. "The Work of Mending: How Pharping People Manage an Exclusivist Response to the Procession of Vajrayogini." In Bowman 2002, 61-78.

Vogler, Bernard. 2000. "Simultaneum." In Theologische Realenzyklopädie Online, TREonline, vol. 31, 280-283.

Weiner, Annette B. 1992. Inalienable Possessions: The Paradox of Keeping-WhileGiving. Berkeley: University of California Press.

Weltecke, Dorothea. 2012. "Multirreligiöse Loca Sancta und die mächtigen Heiligen der Christen." Der Islam 88: 73-95. 


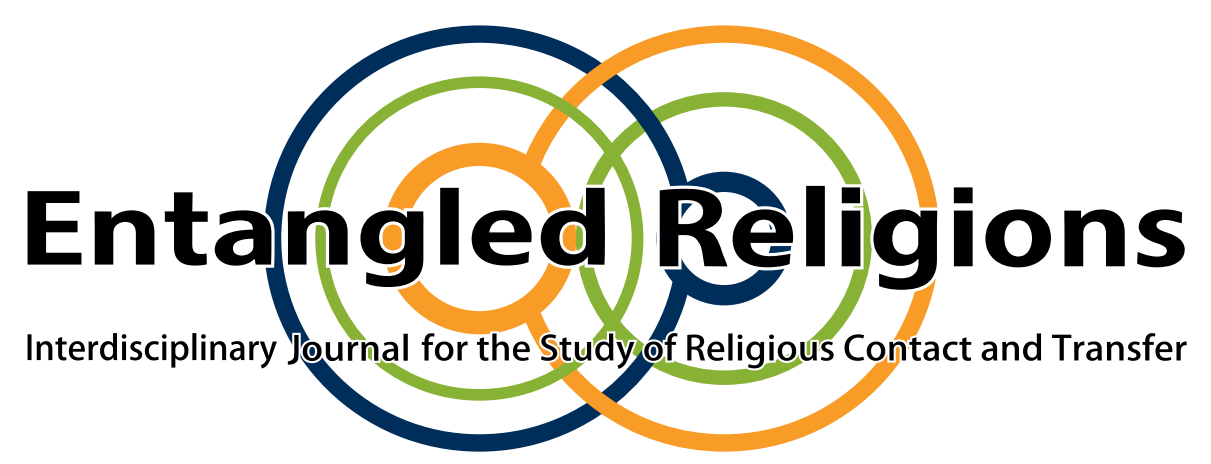

\section{Sacred Spaces in a Holy City.}

Crossing Religious Boundaries in Istanbul at the Turn of the Twenty-First Century

MÉROPI ANASTASSIADOU-DUMONT

INALCO/CERMOM, Paris, France

This contribution to Entangled Religions is published under the Creative Commons Attribution 4.0 International Public License (CC BY 4.0 International). The license can be accessed at https://creativecommons.org/licenses/by/4.0/legalcode.

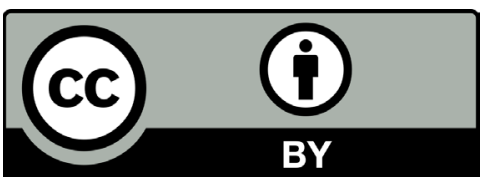

Entangled Religions 9 (2019) http://doi.org/10.13154/er.v9.2019.34-56
RUHR UNIVERSITÄT BOCHUM

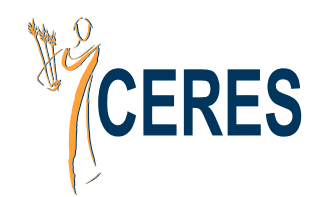

SPONSORED BY THE

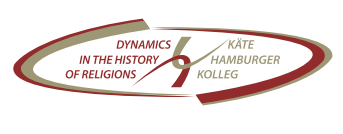




\title{
Sacred Spaces in a Holy City. \\ Crossing Religious Boundaries in Istanbul at the Turn of the Twenty-First Century
}

\author{
MÉROPI ANASTASSIADOU-DUMONT \\ INALCO/CERMOM
}

\begin{abstract}
The article examines Muslim pilgrimages to Christian places of worship in Istanbul after the 1950s. It aims to answer whether and how the Ottoman heritage of cultural diversity fits or does not fit with the pattern of the nation-state. After a brief bibliographic overview of the issue of shared sacred spaces, the presentation assembles, as a first step, some of the key elements of Istanbul's multi-secular links with religious practices: the sanctity of the city both for Christianity and Islam; the long tradition of pilgrimages and their importance for the local economy; meanings and etymologies of the word pilgrimage in the most common languages of the Ottoman space; and the silence of the nineteenth century's Greek sources concerning the sharing of worship. The second part focuses more specifically on some Orthodox Greek sacred spaces in Istanbul increasingly frequented by Muslims during the last decades.
\end{abstract}

KEY WORDS Istanbul; Turkey; Greek-Orthodox; Christians; Muslims; pilgrimages; sacred places; sharing; holy city; relics; Hıderellez; St. George; calendars; ayazma; sacred springs

\section{Introduction}

Throughout time, and especially during the Ottoman era, contacts and exchanges, interactions, hybrid identities, but also different kinds of syncretism were, together with cleavages, permanent features of urban and rural societies in the Eastern Mediterranean region. In contrast to the nation states formed from the nineteenth century onwards, the imperial pattern demonstrates immaterial boundaries more than physical ones. For a large part of the empire's population, the latter remained invisible and distant.

Mental frontiers represented the backbone of rural and urban Ottoman societies. They offered shapes and forms for the diversity of people and cultures hosted for centuries throughout the Mediterranean East. Their role was not only to trace limits but also to generate transgressions and potential interbreeding and hybridity. 
Sharing sacred spaces, using others' places of worship, was recurring, usual, and natural in Ottoman times. It did not necessarily mean that one's original religious identity was denied or abandoned. A Christian could pray before a Muslim tomb without converting to Islam.

\section{State of the Art and Work Hypothesis}

This phenomenon of "sharing" religious practices and rituals has already been widely studied, particularly regarding the space (Mediterranean) and the periods (fifteenth to twenty-first centuries) that interest us here. The British archaeologist Frederick William Hasluck (1878-1920) is one of the first to have considered the question in these terms. After his death in 1929, his wife, Margaret Hardie-Hasluck, published his manuscript in two volumes (877 pages). ${ }^{1}$ Since then, this monumental work represented a kind of "Bible" for all those who later sought to explore the same theme. Christianity and Islam under the Sultans is the work of a lifetime, the result of numerous study tours through Anatolia and the Balkans, carried out between 1904 (Hasluck was then 26 years old) and 1916, a period during which the author was appointed at the British School at Athens. However, it should be noted that Hasluck was not specifically interested in the theme of sharing sacred places! His book focuses on the same question that most of the specialists of the Ottoman Mediterranean, in all disciplines, have studied, namely interactions between Christianity and Islam, exchanges (or the lack thereof) between Christians and Muslims, living together (or not) in this part of the world.

Several decades after the publication of Hasluck's book, the theme of "shared sacred places" would be treated mostly by social anthropologists, but also sociologists and historians-French, British and American. It is undoubtedly significant that in the Eastern Mediterranean countries which formed after the fall of the Ottoman Empire, the production on this subject remained limited and generally adopted a descriptive tone without suggesting any analysis whatsoever. ${ }^{2}$

Over the last twenty years, the works of social anthropologist Dionigi Albera have certainly marked this field of research. Albera has written several articles on the notion of religious sharing before co-directing, with Maria Couroucli, a collective volume of synthesis entitled Sharing Sacred Spaces in the Mediterranean. Christians, Muslims and Jews at Shrines and Sanctuaries (Albera and Couroucli 2012). Including a dozen

1 Hasluck 1929.

2 In this respect, we could mention the book of Efstratios Zenginis (1988), which provides valuable information about spaces of worship in Greek Thrace. The readers will have to make the relevant conclusions. 
articles, this book covers a geographical area that expands from Morocco to Syria via Egypt, Bosnia and Herzegovina, Macedonia, and Albania, without forgetting Istanbul. From a strictly spatial point of view, it follows in the footsteps of Hasluck. With the anthropologist Manoël Pénicaud, Dionigi Albera co-edited one more book on the same theme to accompany the exhibition "Shared Places", organized in the Museum of the History of Immigration in Paris from October 2017 to January 2018 (Albera and Pénicaud 2017).

Another significant contribution to the subject is the collective work directed by anthropologist Glenn Bowman, entitled Sharing the Sacra: The Politics and Pragmatics of Intercommunal Relations around Holy Places (Bowman 2012). Here too, as with Hasluck, the central question is how culturally different people can live together and in peace. The sharing of sacred places is only a compass, a sort of common thread. Unlike Albera, who remains Mediterranean-centered in his analysis, Bowman looks for a global answer. The case studies included in the book focus on China, India and Nepal, Vietnam, but also Turkey.

A global and comparative approach is also a major characteristic of the volume published in 2017 under the direction of Thierry Zarcone and Angela Hobart (Hobart and Zarcone 2017). This book is also not limited to the Mediterranean area, but studies cases from the Indo-Persian world, China, and Amazonian countries. Articles on Switzerland and Brittany figure together in the same section with a study on the relationship between Islam and Buddhism. Zarcone and Hobart's work aims to answer the question of shared beliefs; shared spaces represent a secondary issue, and this is its main difference from the books mentioned above. The collection contains an article by Dionigi Albera claiming the legacy of Hasluck.

The authors of another collective work, edited by Elazar Barkan and Karen Barkey, focus on the notion of "coexistence" in shared sacred places but also study the factors that contribute to interrupting or cancelling sharing. More than the sites themselves, they seek to highlight the socio-political context in which the sharing of places is achieved.

At least two remarks emerge from this brief bibliographic overview. First, recent research on shared sacred places is mostly collective. The need for comparison imposes this mode of operation. Secondly, this research is pluridisciplinary, and even interdisciplinary. Indeed, alongside anthropologists, who are undoubtedly the most numerous, we note the presence of philosophers, sociologists, and historians in this field.

The question this short article aims to answer is a little different from those raised in the aforementioned works. Here, the ambition is to understand how and to what extent the practices of sharing and transgressing cultural boundaries have 
survived within nation-states. What happens to the heritage of cultural diversity once transferred to "homogeneous" nations?

From 1923 onwards, when the republic of Turkey is officially proclaimed with Ankara as its capital, a new chapter starts for the city of Constantine, which is no longer the center of political power. An increasingly Turkish and Muslim population replaces the former multi-cultural human landscape. Its Christian (Greek, Armenian, Catholic, Protestant...) and Jewish components gradually disappear-they either melt away through assimilation or simply physically disappear-and become more and more invisible after the Second World War. However, in contrast to the human landscape, the architectural religious heritage-Muslim and non-Muslim-remains in situ and continues to be used during the entire twentieth century.

What forms did sharing sacred spaces take within the new Kemalist and secular Turkey? How did the authorities deal with practices inherited from a rejected world?

To understand the transition from the imperial model to the national one, as far as the sharing of sacred spaces is concerned, post-Ottoman and mostly Muslim Istanbul is probably the most relevant case to focus on. It will serve as a field of inquiry. The singularity of the former Ottoman capital is that, during this "republican" era, an increasing number of Christian places of worship was used by Muslim pilgrims. This phenomenon has not been systematically studied. My contribution provides some indications but remains insufficient for a global and exhaustive overview.

As in many major Ottoman cities, the "cohabitation of religions" has always been a dominant attribute of the sultan's former capital. Plurality of historical strata and different layers of use of space are also among Istanbul's basic characteristics. More than two thousand years of history have produced a multitude of religious sites, dedicated to various uses depending on the period. In addition, Constantinople / Istanbul, the capital of two empires, is considered a "holy city" in both Christianity and Islam.

Throughout the following pages, the link between the weight of history and the twentieth/twenty-first centuries' realities is strongly underlined. Turkey certainly entered a secular phase from 1923 onwards. However, this Kemalist secularism, inspired by the French model, is hostile to clergymen rather than to religion (Berkes 1964; Landau 1984, 126). People continue to perform their religious observances; the feast of Ramadan is celebrated every year; iftar meals are regularly offered at the presidential residency (Şahin 2011). Despite the dramatic changes due to the collapse of the Ottoman Empire, the istanbuliot society of the inter-war period seems to live an illusion of suspended time. The heritage of the "cohabitation of religions" is deeply rooted in the collective memories. However, after the 1940s, the Christian and Jewish 
presence in the city unceasingly diminishes. ${ }^{3}$ Many Jews leave for Israel, created in 1948. Greeks feel pushed to migrate massively after the events of September $1955 .{ }^{4}$ In 1964, in an extremely tense atmosphere between Athens and Ankara due to the Cyprus question, 10,000 Greeks, all of them Hellenic citizens, are expelled (Akar and Demir 1994; Anastassiadou and Dumont 2011; Akgönül 2004). They are, at least, followed by the members of their families. A total of nearly 50,000 people disappear in a very short period. Step by step, twentieth-century Istanbul is emptied of its nonMuslim inhabitants, and it becomes less and less possible to consider it as a "multireligious" city. Undoubtedly, cultural diversity still remains a major characteristic of the local society: instead of Greeks, Armenians, and Jews, newcomers of various other origins settle in large numbers from the 1980s onwards. Most of them are Kurds or Alevis from Eastern Turkey. There are also immigrants from Asia (Caucasus, the former Soviet Union, Central and Southeast Asia), Africa, and, more recently, from the Arab World. Although certainly "multi-cultural", the present composition consists mostly of Muslims. $^{5}$

As a consequence of these intense migrations, at the beginning of the twenty-first century Christian places of worship are vacant and many of them remain closed and silent. Is the question of shared sacred spaces still an issue to discuss? What is there to be shared with ghosts?

On the basis of these few introductory remarks, the study presented on the following pages is structured into two parts. The first one aims to recall some "useful" elements of the historical background. These are necessary for a better understanding of current modes of behavior, which are linked to the "others'" religion and gained visibility after the 1920s. The second part re-visits some major sacred "shared" spaces which have become increasingly popular during the last decades. A crosssectional question is whether or not shared practices provoke transgressions of (or the temptation to transgress) religious boundaries-in other words, conversion.

3 The bibliography on non-Muslim minorities in post-1923 Turkey is extremely rich and continuously updated. Among many other references, see Akgonül 2005; Akgönül 2010; Akgönül 2013; Alexandris 1983; Anastassiadou and Dumont 2011; Bali 2001; Bali 2005; Bali 2012; Bayır 2013; Bruneau 2015; Çetinoğlu 2009; Doğan 2016; Théodorides 2016.

4 About the events of September 1955, see Vryonis 2005; Güven 2005; Anastassiadou 2009 b.

5 Migration to Istanbul at the end of the twentieth century is a distinct and large research field. Some bibliographical indications include Dumont-Pérouse-Tapia-Akgönül 2002; Bazin and Tapia 2012; İçduygu 2003; iç̧duygu and Kirişci 2009; Tapia 2006. 


\section{A Complex Historical Background}

\section{A Holy City of Christianity and Islam}

The holy character of the city of Constantine for both Christianity and Islam is a first element to underline. In both cases, this sacredness has been almost entirely produced by political power. In his article "Constantinople, a Christian Holy City" (1996), Cyril Mango describes this process, which aims to confirm and consolidate the power of the Roman emperors of the East with substantial religious weight (Mango 1996, 7-11; Ousterhout 2006).

In a world in which political power is systematically deified, it is crucial that the capital city is endowed with all required legitimacy in this respect. The advent of Constantinople as a holy city of Christianity clearly serves this political objective. At the beginning of its Christian era, the city (also called New Rome or New Jerusalem) looks like a replica, a bis, of Christianity's main, founding sacred spaces. During the long Byzantine era, it will become emancipated and develop its own geography of loca sancta (Flusin 2000, 51-70). When they settle in the fifteenth century, the Ottomans do exactly as their predecessors did and make their capital one of the holy places of Islam. In the Muslim world, Istanbul, and especially the Eyüp district, is considered a holy site, together with Mecca, Medina, and Jerusalem.

Various means have been used to underline this status. The systematic collection of relics certainly deserves special mention. Holy Relics-such as the Holy Lance, the Sponge and the True Cross, the Virgin's Robe, the bodies of Saints Andrew and Luc, the head of Saint-John the Baptist, but also the body of Joseph and the right hand of Saint Stephen-were of immense value to Christians and have crucially contributed to the fame of Constantinople throughout Christianity. ${ }^{6}$ Many of them, notably the most significant ones, were acquired personally by the emperors, who used them as major symbols of their authority. Having arrived in Constantinople in $473 \mathrm{CE}$, the "Veil of Mary," for example, regularly served as banner and amulet during military campaigns (Vyzantios 1851-1869, 1587). When the Crusaders took the city in 1204, the relics represented the main spoils of war. Since then, most of them have been kept in various European cities, mainly in Italy (Venice, Florence, Torino...) and France, but also in monasteries of Mount Athos.

6 In his monumental work, entitled "Konstantinoupolis", Skarlatos Vyzantios provides, in three volumes, an exceptionally rich survey of Istanbul's major landmarks of his time (mid-nineteenth century) with systematic references as far back as the very founding of the city. An extremely precious tool for a diachronic perspective on the spot: Vyzantios 1851-1869. 
At the dawn of the twenty-first century, the Church of Constantinople, which experienced the fall of not only Byzantium but also the entire Ottoman era, is trying to restore continuity by reconstituting, at least symbolically, a part of this distant inheritance. In this context, the relics of Gregory the Theologian and John Chrysostom, who, together with Basil the Great, are known as the "three Hierachs" and considered among the most intellectual figures of the early Church, were solemnly returned to the Ecumenical Patriarchate in 2004 on the initiative of Pope John Paul II. Their holy remains are preserved in the patriarchal church of St. George (in the district of Fener) next to those of three sanctified women. Two of the latter-namely St. Euphemia the Great Martyr (fourth century) and St. Theophano the Empress (ninth century)-are closely related to the history of the city. The origin of the third set of relics is less certain. Although attributed to Solomoni, mother of the Maccabees, it is also said to belong to Mary Salome, one of the myrrh-bearing women. The patriarchal church also hosts a portion of the column to which Jesus Christ is said to have been bound and whipped before his crucifixion (column of Christ's Flagellation) (Chryssavgis 2014).

The Ottomans, for their part, strictly implemented the same strategy of constituting a high-level reliquary heritage. The "sacred relics of Islam" (kutsal emanetler), kept today at the Topkapı Palace, were collected by the Ottoman sultans between the sixteenth and nineteenth centuries (Davis 1970; Aydın 2004). Among them, objects that belonged to the Prophet as well as remains of his body (hair, tooth...) are the most valuable ones. Just like in the Byzantine case, they mainly conveyed the legitimacy of the political power. Muhammad's mantle (hırka-i şerif) was an extremely significant trophy for Selim I after his victory over the Mamluks in 1517. It represented the transfer of the spiritual center of gravity within the Muslim world from the Arabs to the Ottomans. And just like the Byzantines, the Ottomans used "holy items" as talismans in a military context. Thus, as the Virgin's veil had previously done, Muhammad's banner played a crucial role when the imperial army was on campaigns, such as those against the Habsburgs at the end of the sixteenth century.

From its very beginning, the Eyüp mosque, located at the base of the Golden Horn, had an identical function, namely to legitimate the Ottoman and Muslim presence and authority in the city. Abu Ayyub al-Ansari, one of the Prophet's companions, is said to have been killed here, during the first siege of Constantinople in 674. His tomb was "discovered" in 1453 and Mehmed II laid the founding stone of the first mosque, dedicated to al-Ansari. Nowadays, the place is still extremely popular; thousands of people come here to pray, especially during the Ramadan period. 


\section{Itineris Sacrae and Pilgrimages: A Major Economic Product}

A second element to be considered as helpful for comprehension is the practice of pilgrimage (or the so called itineris sacrae), which goes back at least to the fourth century in Istanbul. Generally placed under the supervision of the authorities or the communities' organizing bodies, since the very beginning of the Christian era pilgrimages have been strictly controlled activities. They represent a considerable market and, therefore, a valuable economic product. For example, the church of Blachernae and its miraculous source are known to have been the most visited pilgrimage place throughout the whole Empire until the fall of Constantinople in 1453 (Schlumberger 1884; Mango 1998; Papadopoulos 1920). The church was also very

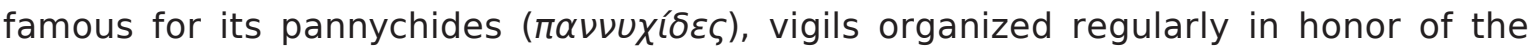
Virgin. However, Blachernae is quite exceptional: even in the Byzantine era, similar pilgrimages, well supported and highly visible, are very few in number.

Instead, the city was-and still is-a huge park of all sorts of sacred mini-topoi, such as neighbourhood churches and mosques, convents (tekke), chapels, and sacred sources. The main and regular visitors of these places are generally people from the neighbourhood or inhabitants of other areas of Greater Istanbul. That is to say, in Constantinople as in Istanbul, besides some exceptional pilgrimages which attract crowds on specific dates and are known to everybody, ordinary life's religiously ritualized practices take place in modest and invisible sites.

On this point, some vocabulary clarifications regarding "pilgrimage" and derivates are needed. Even if these terms conventionally refer to the same phenomenon, the words have divergent etymologies and meanings in Italian, French, Greek, and Turkish, the most commonly used languages in the time and space under study here. This is because they probably corresponded-at least at their beginnings-with different situations and experiences.

The English word pilgrimage or the French pèlerinage derive from the Latin word peregrinus, foreigner, man of the countryside. Peregrinatio refers to traveling in a distant and foreign land.

In Greek, the sense of what is considered nowadays as the equivalent is entirely

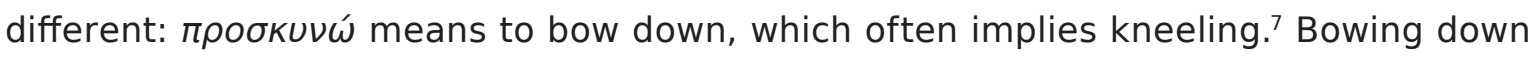

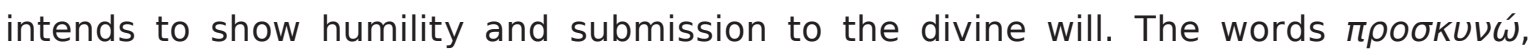

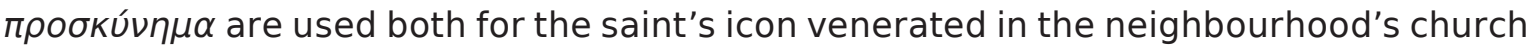

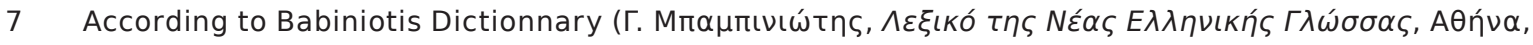

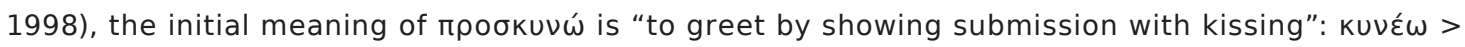

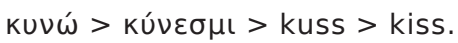




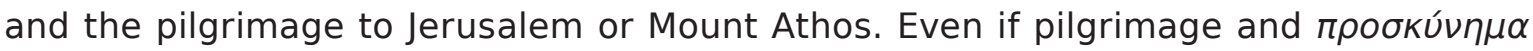
are practically synonymous today, they are far from having the same origin.

The linguistic landscape in Turkish is also very different. The word hac refers, as the Arabic hajj, to the pilgrimage to Mecca. For "pilgrimage" elsewhere than to Mecca, the Turkish word commonly used is ziyaret, which is of Arabic origin, too, and literally means "visit". In everyday life, within the Turkish Muslim world most of the ziyaretçi (pilgrims) worship mainly the yatır (from yatmak, to lie down), that is to say illustrious dead whose actions during their lifetime brought them close to Allah. There are dozens of tombs (türbe) of these yatır throughout Istanbul and its surroundings. They are called adak yerleri, literally "places of vow."

\section{Silent Sources. No Mention of Sharing Sacred Spaces in Nineteenth-Century Greek Written Literature}

Available evidence on shared practices within the nineteenth-century written production in the Greek language is another useful element to take into account. Until the end of the imperial era (1918), Orthodox Greeks represented not only the most numerous Christian community of the Ottoman capital but also the most ancient and historic one; this is why their positioning towards sharing places of worship is highly significant.

For Istanbul Greeks, the long nineteenth century is a period of prosperity from all points of view, economic, demographic, and intellectual. It is, in particular, a period of intense editorial activity. A number of books, newspapers, and periodicals were published in the Greek language in Constantinople. ${ }^{8}$

In this literature, the presentation of places of worship is prominent. The objective is evidently to patrimonialize, that is to say to create a collective awareness of centuries-old roots on the spot, especially for those Istanbul Greeks who came from the provinces (and settled as new immigrants) (Anastassiadou 2009a). Greek intellectuals are not necessarily conscious of their effort to transmit to their coreligionists a sense of "ownership" towards the orthodox sacred spaces throughout the city.

It is noteworthy that nowhere in this production is there the slightest indication about sharing some places of worship with Muslims. Only in one case, a common celebration on the occasion of St. George is briefly mentioned. It is Manouil Gedeon, great chartophylax ${ }^{9}$ of the Patriarchate, one of the last Phanariots and probably the

8 Today, an important part of this material is kept in the libraries of the Phanar's Ecumenical Patriarchate and the Halki Orthodox Seminar (Heybeliada, Princes Islands).

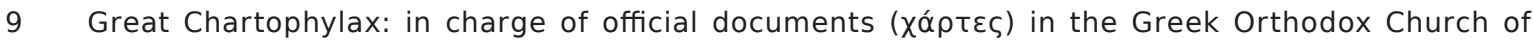
Constantinople during the Byzantine period. Nowadays it is only an honorific distinction. Until the 
most illustrious scholar of this Greek-Constantinopolitan world of the late Ottoman era, who affirms this. In his article "St. George in Constantine's City", published in 1937 (Gedeon 1937), Gedeon notes that until the end of the eighteenth century, Muslims used to bring offerings to St. George and participate in the communal meal after Mass. He also reports that from 1859, when his family settled in the district of Phanar, every year he could personally see from his window on the opposite shore of the Golden Horn, on the hills of Kasım paşa, lights sparkling during the whole night of April 22 to 23. It was, he assures, Muslim Gypsies, who (also) venerated the saint until dawn.

Obviously, both the silence of the Greek sources and the Gedeon exception need some interpretation. The question to be answered is whether available written materials "tell the truth" and whether there were indeed no shared places of worship with Muslims, or if they simply reflect a taboo on the subject.

It is likely that the situation described by Greek scholars is somehow offset from reality. The period strongly argues in favor of this hypothesis. The emergence of nationalisms in the nineteenth century encourages the development of protonationalisms. The intellectual elites of Ottoman society's various components draw their collective identity's outline without leaving any kind of ambiguity (or hybridity) to interfere. Greeks do likewise. Many of them avoid Athenian nationalist debates, but especially so Istanbul Greek scholars, who also seek to distance themselves from "Ottomanism" by avoiding any kind of mixing between Greek orthodox and non-Greek orthodox. Could things be different in such a time?

However, everyday reality must have been quite different from what is reported in the books. From oral testimonies, ${ }^{10}$ we know, for example, that Christians used to go on pilgrimage to Rumeli Kavağı ${ }^{11}$ on the tomb of Telli Baba (alias İmam Abdullah Efendi), who had been killed as a martyr at the time of Mehmed II and considered one of the four guardians of the Bosphorus. Telli Baba had an excellent reputation among young women who wanted to know whether (and to whom) they would get married, become pregnant, or have a boy. Needless to stress that written evidence of such practices can be found buried in personal diaries of young girls. Buried and not stated: it is certainly meaningful that published material in Greek language does not include any indication about them.

end of the Ottoman Empire, this function was attributed mostly to intellectual figures. That was the Gedeon case.

10 Interviews realized in Istanbul from 2005 to 2015 with Greek Orthodox and Catholics, men and women, aged between 60 and 80 .

11 Rumeli Kavağı: neighbourhood on the northern part of the Bosphorus, not far from the Black Sea on the European shore, district of Sarıyer. Checkpoint for commercial vessels in Ottoman times. 
Why then, in such an atmosphere (of probable self-censorship), does Manouil Gedeon, whose authority is indisputable, adopt a countercurrent position and mention the feasts of Muslim Gypsies worshipping St. George? We can suppose that the information given about this shared feast aimed mainly at highlighting the presence of Gypsies, transgressors by excellence, as it were, and thus underscoring the relative discretion of "other", ordinary Muslims. During the Tanzimat era (from 1839 onwards), religious conversion is still quite a common phenomenon, especially in the anonymity of the city, and the various communities remain extremely vigilant towards their "troops". ${ }^{12}$ In such a framework, it is almost impossible for a Greek author, in addition dignitary of the Phanar, to attribute Christian religious practices to "ordinary" Muslims.

Besides, were Kasım paşa's Gypsies really worshipping St. George? Gedeon probably did not ignore that that very same day, April 23, Muslims celebrated Hıderellez ${ }^{13}$ to welcome summer. Was there in fact any transgression? Something to "share"?

Hiderellez and St. George are considered to correspond with the same figure. Hasluck explains this (Hasluck 1929, 320-321):

In Turkey, generally, Khidr seems to be a vague personality conceived of mainly as a helper in sudden need, especially of travellers. He has been identified with various figures of the Old Testament, notably with Elias of whom he is considered a reincarnation, and with the Orthodox St George, whose day...he has taken over; the characteristics he has borrowed from St George include the reputation of a dragonslayer, which St George himself may have borrowed from a pagan predecessor.

Whatever the link between Hiderellez and St George is, their feasts occured on the same date (April 23, according to the Julian calendar), at the very moment of the Pleiades constellation's appearance in the sky (Gökalp 1978). This astronomical phenomenon, which happens twice a year (on April 23 and October 26, according to the Julian calendar), divides one year's time into two main seasons, winter and summer.

When Gedeon observed Kasım paşa's Gypsies, Orthodox Greeks were indeed using the Julian calendar. In the 1920s, the Greek Orthodox Church adopted the Gregorian

12 The challenge was to not lose people and weaken the demographic presence in a very antagonistic context. Many thorough studies have been dedicated to religious conversions at the end of the Ottoman era. Among many others, see: Deringil 2012.

13 Hıderellez is the day where Hızır (Al-Khidr), a major Sufi figure, and Ilyas (prophet Elijah) meet. The first is linked to spring and revival; the second brings rain. Hiderellez is also the first day of the warm season. On the joint feast of Hiderellez and St Georges, see Hasluck 1929, 48, 321; Doumanis 2012, 125-127. 
one, ${ }^{14}$ albeit without changing the feast dates of its numerous saints; April 23 is still the St. George day. However, between the two calendars (Julian and Gregorian/revised Julian, known as old and new in the Orthodox world ${ }^{15}$ ) there is presently a difference of 13 days. This is why nowadays Hiderellez, which follows the Pleiades movement, is celebrated on May 5/6.

\section{Sharing Sacred Spaces during the Second Half of the Twentieth Century}

Since the Second World War, the visibility of "shared" places of worship in Istanbul has unceasingly grown. When there is "sharing", that is to say worshippers from different religions, a source of water almost always dominates the space; and not ordinary sources, but "holy" ones, with "proved" therapeutic and miraculous qualities.

Water sources abound in Istanbul-and this is a geological characteristic! They appear, disappear, and reappear through the centuries and represent major landmarks, material and mental ones, for the city's successive occupants. In his book published in 1990, Nikos Atzemoglou claims to have identified and inventoried more than 500 sources, but estimates that the total number probably exceeds one thousand holy springs throughout the agglomeration (Atzemoglou 1990; see also Kourilas 1958). More recent studies focus on the Byzantine period and the importance of water-sacred water-for healing from all sorts of suffering (Shilling and Stephenson 2016; Pitarakis and Tanman 2018; Ousterhout 2018).

The Greek word ayazma ( $\alpha$ yí $\alpha \mu \alpha$ ), used in Turkish to name holy water sources, reveals that their presence in the local context goes back to the beginning of the city's historical itinerary, when Greek was the most widespread spoken tongue before becoming Byzantium's official language. In modern Greek, $\alpha$ үí $\alpha \mu \alpha$ means exactly what ayazma does: not any source, but exclusively the sacred one. In this respect, it is useful

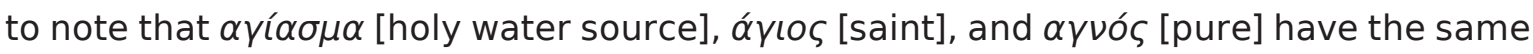
etymological origin, sketching out purity, purification, pure.

14 Gregorian? Not exactly. The calendar used by most Orthodox Greek Churches (Phanar included) is known as the "Revised Julian Calendar." All feasts fit to the Gregorian calendar except for Easter, for which the old calendar remains in force. The Church of Greece adopted this revised Julian calendar in 1923. In Turkey, the Gregorian calendar was introduced from January 1, 1926.

15 It is estimated that at the end of the twentieth century, there were 700,000 to 1 million old calendarists in Greece (Greek Helsinki Monitor, Religious Freedom in Greece, Report 2002, 3, quoted by Maghioros 2013, 138). On the old calendarists, see Kitsikis 1994, 17-51. 
For those practicing Islam in Istanbul, going to a water point to make a vow is a natural part of everyday life's pious activities. Most often, with regard to Muslim sites, the water point is either a well or a fountain. For example, the place called Niyet Kuyusu (literally: wishing well) in Eyüp is a well (kuyu) visited mostly by women who seek to communicate with people gone or dead, but also to get back a lost object (Alus n.d.). Those who suffer from jaundice go to the baths (hammam) of the Süleymaniye mosque: ${ }^{16}$ here, it is more the bowl used for drinking than the water itself which is efficient.

It is to be observed that wells (or fountains) and sources generate diametrically opposite actions. In the first case, the visitor / pilgrim throws in an object (a stone or coin) but has no direct contact with the water. In the second case, the water comes to the worshipper and chases suffering away. The difference is obvious.

Ayazmas are a Greek Orthodox specificity in Istanbul. Currently, many located in private spaces (such as gardens, restaurants (!), and houses) are either abandoned or visited only occasionally. A considerable number of ayazmas is also found in churches or their courtyards and maintained by the parishes. Istanbul Greeks still frequent these places, which are usually strongly linked to the community's collective identity or the sense of belonging to the city. Because they are quite a ways away from touristic spots, the ayazmas on the Bosphorus, in particular (Yeniköy, Çengelköy, Arnavutköy, for example), illustrate these "local" pilgrimages well. In the historic center, certain ayazmas interest and attract Christians from outside, pilgrim-tourists who come mainly from Greece but also from other orthodox countries, such as Russia, Romania, Bulgaria, etc. In this respect, the most famous one is, as it was during Byzantine times, the sacred spring in the church of Blachernes on the Golden Horn, not far from Eyüp (Anastassiadou 2014). For the Greeks, wherever they are, this Virgin's shrine is a central piece of their cultural identity. Many of them go not only for the spring but also for the icon of Mary; when they come from far away, they practice what anthropologists call "tourism of memory".

In ayazmas where Muslims come in large numbers, local Greeks remain, if not invisible, at least discreet. Are they reactivating the nineteenth century's reflexes? Do they abstain from showing up with "others" who represent, as in the last Ottoman phase, a potential danger of conversion? It is also plausible that a massive Muslim presence can be perceived as a desacralizing factor for practicing Christians and transform the religious feast into a folk event.

16 The bath (hammam) constitutes a part of the installations (complex, külliye) around the mosque. 
Whatever the reason, nowadays some popular ayazmas and the churches that house them are pilgrimage places not only for Christians but also for a large number of Muslims. Four of them are worth being presented briefly here.

The most famous Muslim pilgrimage to a Christian ayazma takes place every year on April $23^{17}$ at the Byzantine monastery of St. George Koudounas ("with the bells") in Büyükada (Princes Island). ${ }^{18}$ Even if Hıderellez and St. George are not celebrated on the same date any more, connexions between the two festivals are still subconsciously present in the collective memories. People, especially women, climb up the hill to Ayo-Yorgi (Greek and Turkish form of St. George) to make a vow and take water from the source. Since the last twenty years, the pilgrimage has been strongly supported and advertised through television. Ayo-Yorgi's popularity leads over 40000 pilgrims and visitors to the island in one single day. This strong affluence of Muslim worshippers underlines the absence of Christians even more. In contrast, the latter, inhabitants of the islands but also Istanbul residents, used to be very present before the 1990s. According to oral testimonies, ${ }^{19}$ "in the old times", probably referring to the 1950s and 1960s, the Greeks went up the hill regularly for Easter. Nocturnal processions of Holy Saturday, with lit candles and chanting, have marked the memories of the elders and are repeatedly recounted. It is certainly interesting to note that in these accounts, like in those of the nineteenth century, there is never any Muslim mentioned.

Although Ayo-Yorgi of Prinkipo (the Greek name for Büyükada) has by far become the most mediatized Muslim pilgrimage to a Christian place in Turkey since the 1990s, there are many other sites throughout Istanbul known to be "miraculous" that receive crowds of visitors on certain dates. The installations of all three Orthodox ayazma presented hereafter were destroyed during the events of 1955 (September 6/7, pogrom against the Greeks). ${ }^{20}$ They constituted a privileged target for the mob, which apparently did not ignore their extreme symbolic value for Greek collective memory.

The sacred source (ayazma) of Ay-Tarap is one of the oldest pilgrimage places.

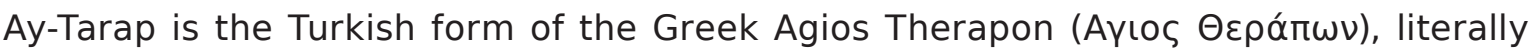

17 It must be noted that in the Greek Orthodox Church, if April 23 falls during Lent, the feast is celebrated on Easter Monday. Muslim pilgrims either ignore or override this rule and come to Büyükada on April 23 without taking into account Easter calendar regulations.

18 In this case, too, the bibliography, especially in Greek and in Turkish, is considerable. For an excellent synthesis, see the film of Mathias Gokalp, Dilek / Le voeu, 2004, Karé Productions, 27 mn. See also Couroucli 2012.

19 Information given by Greeks of Büyükada, who lived on the island during the 1950s.

20 On the 1955 events, many published works are available in Greek and Turkish (see footnote 3). For an approach in English, see Vryonis 2005. 
meaning St. Healer, the word $\theta \varepsilon \rho \alpha ́ \pi \omega \nu$ deriving from $\theta \varepsilon \rho \alpha \Pi \varepsilon i ́ \alpha$ / therapy. He is imported from Cyprus, where he is identified with St. Arab. Let us read Hasluck again:

\begin{abstract}
...S. Arab, Larnaca (Cyprus). This is another ambiguous cult... At the present day this sanctuary is still frequented both by Turks and Greeks. By the former it is known as Turabi Tekke, by the latter as S. Therapon. Turabi is the name of a wandering dervish from Kastamoni in northern Anatolia, who lived in the reign of Mohammed II and was noted for his liberal views as to religions outside Islam. S. Therapon is a well-known saint and healer in Cyprus, where he has several churches; he is not however especially connected with Larnaca. As to the origins of a cult of this sort, it is impossible to be dogmatic. From the evidence we have it seems probable that it began as a secular cult of an 'Arab' jinn, later identified with Turabi (perhaps

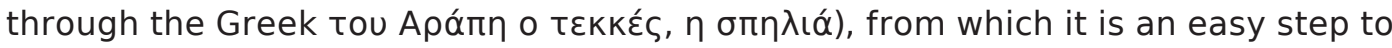
the Christian Therapon. If this theory is correct, we have here a cult now shared by both religions, whose origins were neither Christian no Mohammedan, but secular... (Hasluck 1929, 87-88).
\end{abstract}

Officially, from the point of view of the Orthodox Church and according to the Orthodox lives of the saints, Agios Therapon is a seventh-century martyr whose relics had been transported from Cyprus to Constantinople. The ayazma dedicated to him is close to Topkapı Palace. In the 1820s, after significant work, the source's bed was transferred outside of the enclosure of the Saray. Presumably, the place was among the busiest of the city at that time already. In the beginning of the republican era (1920s and 1930s), the Greek school of the neighbourhood (district) was fully financed by the ayazma revenues. During the 1970s and 1980s, a priest met the pilgrims, henceforth Muslims, every Monday afternoon (Atzemoglou 1990, 17-19).

In Kuruçeşme (Xirokrini / Enрoкрńvn, in Greek), a village on the European shore of the Bosphorus, long queues in front of the church of St. Demetrius (Agios Dimitrios in Greek; Ayo-Dimitri in the local tongue) can be seen on certain days of the year. Here, the source lies at the end of a 40 meter long narrow and low-ceilinged tunnel that is constantly wet. Water drops (of sacred water!) hang from its rocky walls. When arriving at the source, the pilgrim / visitor is already soaked in ayazma. Those who go to Xirokrini know that the efficiency of their pilgrimage and the fulfillment of their wish require precise rituals. A piece of cloth or a garment has to be left in front of the source when the vow is expressed; until recently, there were rings around the source which mute children were supposed to bite in order to be able to speak again (Atzemoglou 1990, 104). 
Open on Thursdays and the first day of every month, the ayazma of Vefa is another Orthodox space of worship extremely fashionable among Muslims nowadays (Atzemoglou 1990, 21-23). The place is dedicated to the Dormition of the Virgin

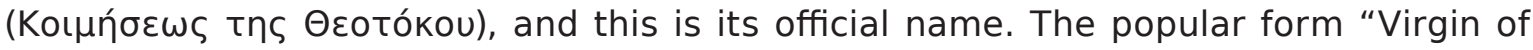

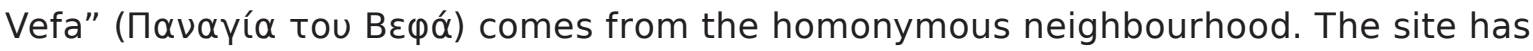
been known since Byzantine times. A church dedicated to Mary's death existed here long before the fall of Constantinople. After the Ottoman conquest, it was demolished and the source dried up. The water re-appeared in the eighteenth century, and construction on the current building began in the 1870s. Several elements were added until the beginning of the twentieth century, but also after the damages of September, 6/7 1955. In the 1960s and 1970s, Istanbul Greeks used to come as families on every first day of January to make a vow and ask for the blessing of the Mother of Jesus. This

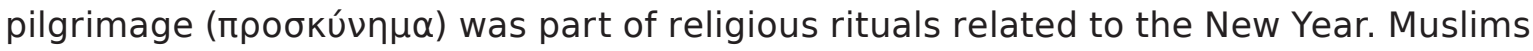
became increasingly present and visible, especially from the 1960s onwards.

Representatives of official Islam do not recognize these practices but turn a blind eye to them; it seems preferable to let events take their course and watch from afar rather than prohibit. For its part, the Ecumenical Patriarchate, responsible for these places and for controlling large crowds of people, is obligated to provide a reinforced security service. Just like in Ayo-Yorgi of Büyükada, in Sirkeci (Ay-Tarap), in Kuruçesme (Ayo-Dimitri), and in Vefa (Virgin), religious practices are perfectly framed and ritualized. Neither improvisation nor surprises are admitted.

What is to be deduced from these few examples of shared places of worship in twenty-first-century Istanbul? First, we can claim that the disappearance of the Greeks from the urban landscape and the desertification of their churches, chapels, and other sanctuaries made the Muslim presence visible, and that the latter benefited from the eradication of Christians. ${ }^{21}$ However, this explanation, which seems logical, does not take into account the socio-economic evolutions within the Turkish metropolis during the last decades.

Indeed, due to a massive rural exodus, Istanbul's population underwent spectacular growth especially after the 1970s and 1980s. ${ }^{22}$ Not only are there no more Greeks, but the new inhabitants of the city are overwhelmingly Muslims (Sunni or Shiite) and rural, adhering to a popular piety and familiar with, and open to, hurafe (superstitions) that official (and urban) Islam strives to eradicate. As immigrants, they look for landmarks and support in their new home. The places of worship, theirs but also those of others, are spaces of solidarity par excellence. Places to hang on to, where to share hope and

21 In 2019, more than 90 Greek Orthox churches (places of worship) are still open and active throughout the Istanbul area.

221.16 million inhabitants in 1950; 4.75 millions in 1980; 15 millions in 2017. Source: www.ibb.gov.tr 
despair. Making a vow before a non-Muslim sacred figure does not entail abandoning one's own faith. It can be an added value or a neutral event. But it neither hurts nor damages what already exists. As a sacristan at the Vefa ayazma was heard to murmur to a hesitating observer once, "Go ahead and get one, there is no risk in taking a small flask of ayazma, nothing terrible can happen to you!"

These observations raise a new question, which leads to new working hypotheses that go beyond the limits of this brief study but may give rise to future research. Is a correlation between the increasing visibility of Islam within Turkish and Istanbuliot society and the Muslim presence in Christian religious spaces plausible? In other words, could the latter simply be an aspect of a much more general phenomenon? Timing is favorable to such a hypothesis. Not only do the Greeks disappear gradually after the 1950s, leaving behind an immense religious heritage that is no longer used, but during the same period, the Kemalist parenthesis is over and signs or symbols of Islam are steadily reintroduced into the social landscape. Religiosity is now expressed more and more publicly. To these contextual elements, it should be added that the question of shared places of worship in Istanbul (that is to say, on a strictly local scale) in the interwar period is understudied; not much knowledge on this subject exists. Written sources are lacking and those who could testify orally are less and less able to do so.

\section{Concluding Remarks}

The main observation that emerges from the preceding pages is that popular forms of religiosity are very resistant and part of a remarkable continuity. Continuum and continuity: this is probably the major outcome of this study.

Continuum / continuity with respect to chronic fears (on both sides) of conversion. A question rarely put in words but present in the mind is whether Muslims who become accustomed to going to Christian sacred places are likely to convert to Christianity. A constant fear of Christian priests and other clergymen in Turkey is to be accused of proselytism. Although active in Anatolia (and in the southeastern provinces), Protestants have a discreet presence in Istanbul and seem relatively protected against such suspicions. The same is true for Catholics. In practice, the Orthodox-that is to say the Phanar-are potentially the main concern for Islamic religious authorities, because of places of worship which are under their responsibility and attract masses of Muslim pilgrims. This is why the Church of Constantinople strictly controls such activities. ${ }^{23}$

23 Concretely, when people start going to "others' religious places", they are probably, in the beginning, only pushed by curiosity. But this curiosity can create religious complicity likely to lead to conversion. The opacity on the subject is nearly total. Impossible to say how many are those 
Continuum / continuity also as regards the relationship between shared practices or spaces and public authorities. As already stated, since the very founding of the city, religious activity in Istanbul has always been under state scrutiny. When looking at the present situation, we can remark that Ankara has the same attitude towards the religious practices of Muslims on Christian places as the Ottomans did towards all kinds of social deviance (begging, prostitution, vagrancy ${ }^{24}$ ): be watchful, organize, and to monitor in order not to lose control. Even if official Islam does not approve of either the candles lit in front of Christian holy icons or the prayers Orthodox priests address to Muslims, it turns a blind eye-at least as long as boundaries of strictly religious practices are not transgressed.

Continuum / continuity finally as to the national narrative. Recall that "cultural diversity" was introduced into national discourse from the beginning of modern Turkey onwards. Despite the nation-building process, it is in accordance with an official ideology. Even the Kemalist authorities sought to stress the multicultural roots of Turkey and to support the idea of Anatolia as the cradle of civilisations. ${ }^{25}$

In twenty-first-century Turkey, cultural diversity is an Ottoman heritage, all the more precious as it underlines the legitimacy of the Turkish state to claim the exclusivity of the imperial succession. It recalls the tolerance and magnanimity of the Ottomans towards their zimmis that Ankara takes into account to better highlight the superiority and supremacy of Islam. In this context and during the same period (2005), the choice was made to exhibit Christian and Jewish sacred relics at the Topkapı palace, kept in the Saray's deposits since Ottoman times, together with Muslim ones. The message is clear: "interreligious sharing" is wished, organized and controlled by the state.

\section{Bibliography}

Akgönül, Samim. 2004. Les Grecs de Turquie: processus d'extinction d'une minorité de l'âge de l'Etat-nation à l'âge de la mondialisation: 1923-2001. Louvain La Neuve: Academia Bruylant.

who eventually embrace Christianity, after years of pilgrimage to the ayazmas of the city. Very rare cases, notorious within the Greek minority, are almost always mentioned as exceptional.

24 Beggars and vagrants in the Ottoman period have been extensively studied. Among many other references, about Istanbul, see Özbek 1999; Tekin 1999.

25 Mustafa Kemal himself largely promoted this idea since the very beginning of the Turkish Republic. Over sixty years later, Turgut Özal (Turkey's prime minister and president in the 1980s) developed and elaborated it in his La Turquie en Europe (Özal 1988). 
- - . 2005. Le patriarcat grec orthodoxe: de l'isolement à l'internationalisation de 1923 à nos jours. Paris: Maisonneuve et Larose.

-_- 2010. Minorités en Turquie, Turcs en minorité. Regards croisés sur l'alterité collective dans le contexte turc. Istanbul: Isis.

-_- 2013. The Minority Concept in the Turkish Context. Practices and Perceptions in Turkey, Greece and France. Leiden: Brill.

Albera, Dionigi, and Maria Couroucli, eds. 2012. Sharing Sacred Spaces in the Mediterranean: Christians, Muslims and Jews at Shrines and Sanctuaries. Bloomington: Indiana University Press.

Albera, Dionigi, and Manoël Pénicaud, eds. 2017. Coexistences. Lieux saints partagés en Europe et en Méditerranée. Musée national de I'histoire de l'immigration (Paris). Arles: Actes Sud.

Alexandris, Alexis. 1983. The Greek Minority of Istanbul and Greek-Turkish Relations, 1918-1974. Athens: Center for Asia Minor Studies.

Alus, Sermed Muhtar. n.d. İstanbulu Dolaşırken. Eyüp Semti. Kişisel Arşivlerde İstanbul Belleği: Taha Toros Arşivi.

Anastassiadou, Méropi, and Paul Dumont. 2011. Les Grecs d'Istanbul et le patriarcat oecuménique au seuil du XXIe siècle: une communauté en quête d'avenir. Paris: Editions du Cerf.

Anastassiadou, Méropi. 2009a. "Greek Orthodox immigrants and modes of integration within the urban society of Istanbul (1850-1923)." Mediterranean Historical Review 24 (2): 151-167.

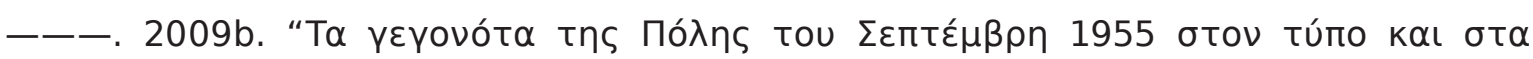

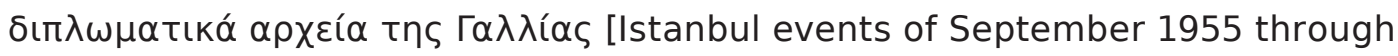

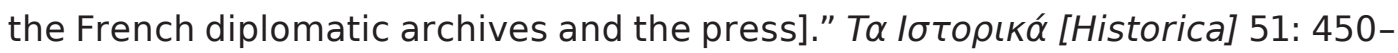
462.

- - - 2014. "Making Urban Identity, Dividing Up Urban Time. Festivities among the Greeks of Istanbul in the Nineteenth and Twentieth Centuries." In Celebration, Entertainment and Theatre in the Ottoman World, edited by Suraiya Faroqhi and Arzu Öztürkmen, 237-260. London: Seagull Books.

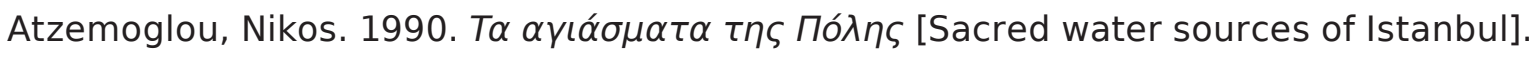
Athens: Rissos.

Aydın, Hilmi. 2004. The Sacred Trust. Pavillon of the Sacred Relics. Istanbul: Tughra Books.

Bali, Rıfat. 2001. Les relation entre Turcs et Juifs dans la Turquie moderne. Istanbul: Isis.

-_- 2005. Cumhuriyet Yıllarında Türkiye Yahudileri. Bir Türkleştirme Serüveni [Turkey's Jews in the Republican Era. An Odyssey of Turkification]. İstanbul: İletişim. 
- - . 2012. The Wealth Tax (Varlık Vergisi) Affair: Documents from the British National Archives. Istanbul: Libra.

Barkan, Elazar, and Karen Barkey, eds. 2014. Choreographies of Shared Sacred Sites. Religion, Politics and Conflict Resolution. New York: Columbia University Press.

Bayir, Derya. 2013. Minorities and Nationalism in Turkish Law. Farnham-Burlington: Ashgate.

Bazin, Marcel, and Stéphane de Tapia. 2012. La Turquie. Géographie d'une puissance émergente. Paris: Armand Colin.

Berkes, Niyazi. 1964. The Development of Secularism in Turkey. Montreal: McGill University Press.

Bowman, Glenn. 2012. Sharing the Sacra. The Politics and Pragmatics of Intercommunal Relations around Holy Places. New York: Berghahn Books.

Bruneau, Michel. 2015. De l'Asie Mineure à la Turquie: minorities, homogénéisation ethno-nationale, diasporas. Paris: CNRS éditions.

Çetinoğlu, Sait. 2009. Ekonomik ve kültürel jenosit: Varlık Vergisi 1942-1944. İstanbul: Belge Yayınları.

Chryssavgis, John. 2014. The Ecumenical Patriarchate Today. Sacred Greek Orthodox Sites of Istanbul. Istanbul: London Editions Turkey.

Couroucli, Maria. 2012. "Saint George the Anatolian, Master of Frontiers." In Albera and Couroucli 2012, 118-130.

Davis, Fanny. 1970. The Palace of Topkapı in Istanbul. New York: Scribner.

Demir, Hülya, and Rıdvan Akar. 1994. Istanbul'un Son Sürgünleri [Istanbul's last deportations]. İstanbul: İletişim.

Deringil, Selim. 2012. Conversion and Apostasy in the Late Ottoman Empire. New York: Cambridge University Press.

Doğan, Ali Kemal. 2016. L'évolution de la laïcité turque sous le gouvernement de I'AKP à travers le sort des minorités religieuses. Aix-en-Provence: Presses universitaires d'Aix-Marseille.

Doumanis, Nicholas. 2012. Before the Nation. Muslim-Christian Coexistence and its Destruction in Late Ottoman Anatolia. Oxford: Oxford University Press.

Dumont, Paul, Jean-François Pérouse, Stéphane de Tapia, and Samim Akgönül. 2002. Migrations et mobilités internationales: la plateforme turque. Istanbul: Les dossiers de l'IFEA.

Flusin, Bernard. 2000. "Construire une nouvelle Jérusalem. Constantinople et ses reliques." In L'Orient dans l'histoire religieuse de l'Europe: l'invention des origines, edited by Mohammed Ali Amir-Moezzi and John Scheid, 51-70. Turnhout: Brepols Publishers. 


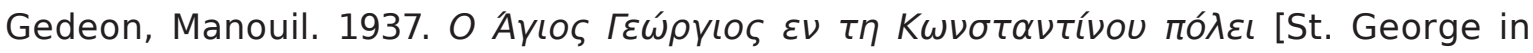

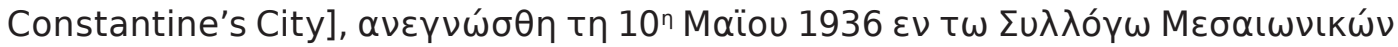

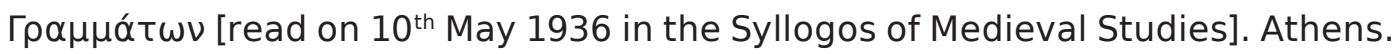

Gökalp, Altan. 1978. "Hızır, Ilyas, Hıdrellez: les maîtres du temps, le temps des hommes." In Quand le crible était dans la paille. Hommage à Pertev Naili Boratav, edited by Rémy Dor and Michèle Nicolas, 211-231. Paris: G.P. Maisonneuve \& Larose. Güven, Dilek. 2005. 6-7 Eylül Olayları: Cumhuriyet Dönemi Azınlık Politikaları ve Stratejileri Bağlamında [The events of September 6-7 in the framework of strategies and policies towards minorities in the Republican Era]. İstanbul: Tarih Vakfı.

Hasluck, F. W. 1929. Christianity and Islam under the Sultans, 2 vols. Oxford: At the Clarendon Press.

Hobart, Angela, and Thierry Zarcone, eds. 2017. Pilgrimage and Ambiguity: Sharing the Sacred. Canon Pyon: Sean Kingston Publishing.

İçduygu, Ahmet, and Kemal Kirişci. 2009. Land of Diverse Migrations: Challenges of Emigration and Immigration in Turkey. İstanbul: Bilgi University.

İçduygu, Ahmet. 2003. Irregular Migration in Turkey. Geneva: IOM.

Kitsikis, Dimitri. 1994. "Les anciens calendaristes depuis 1923 et la montée de I'intégrisme en Grèce." CEMOTI 17: 17-51.

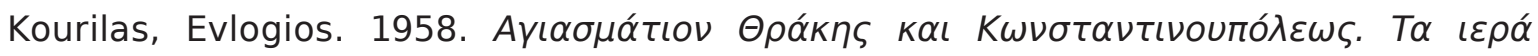

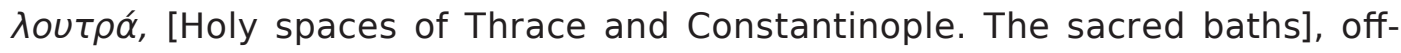

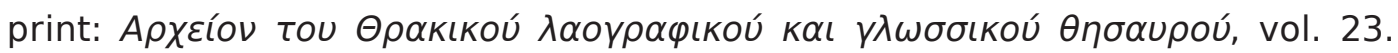
Athens.

Maghioros, Nikos. 2013. "Religious Education in Greece." In The Routledge International Handbook of Religious Education, edited by Derek H. Davis and Elena Miroshnikova, 130-138. London: Routledge.

Mango, Cyril. 1996. "Constantinople, a Christian Holy City." In Istanbul-World City, 7-11. Istanbul: Tarih Vakfı.

- - . 1998. "The Origins of the Blachernae Shrine at Constantinople." In Actes du 13e Congrès international d'Archéologie chrétienne, 61-76. Split: Archeological Museum \& Rome: Pontificio Istituto di Archeologia Cristiana.

Landau, Jacob, ed. 1984. Atatürk and the Modernization of Turkey. Boulder, Colo.: Westview Press \& Leiden: Brill.

Ousterhout, Robert. 2006. "Sacred Geographies and Holy Cities. Constantinople as Jerusalem." In Hierotopy: the Creation of Sacred Space in Byzantium and Medieval Russia, edited by A. Lidov, 98-116. Moscow: Indrik. 
- - 2018. "Water and Healing in Constantinople. Reading the Architectural Remains." In Life is Short, Art Long: The Art of Healing in Byzantium, edited by Brigitte Pitarakis and Gülru Tanman, 65-77. Istanbul: Istanbul Research Institute.

Özal, Turgut. 1988. La Turquie en Europe. Paris: Plon.

Özbek, Nadir. 1999. “II. Meşrutiyet İstanbul'unda Dilenciler ve Serseriler [Istanbul Beggars and Vagrants during the Youg-Turk period]." Toplumsal Tarih Dergisi 64, 34-43. İstanbul.

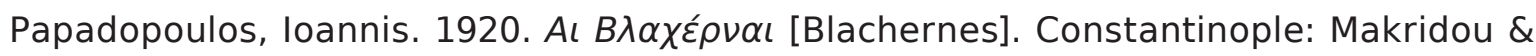
Alevropoulou.

Pitarakis, Brigitte, and Gülru Tanman, eds. 2018. Life is Short, Art Long: The Art of Healing in Byzantium. Istanbul: Istanbul Research Institute.

Şahin, Ali. 2011. Medyada Ramazan ve Dini Bayramlar, Cumhuriyet Gazetesi Örneği [Ramadan and religious feasts in the media. The case of the Cumhuriyet journal], unpublished MA thesis, Faculty of Social Sciences, Uludag University (Bursa), quoted in: Ayse Hür. "Atatürk zamanında dini bayramlar nasıl kutlanırdı? [How were religious feasts celebrated at the time of Atatürk?]." Radikal. October 5, 2014. http://www.radikal.com.tr/yazarlar/ayse-hur/ataturk-zamaninda-dinibayramlar-nasil-kutlanirdi-1216993/.

Schlumberger, Gustave. 1884. Les îles des Princes - Le palais et l'église des Blachernes - La grande muraille de Byzance. Souvenirs d'Orient. Paris: Calmann Lévy.

Shilling, Brooke, and Paul Stephenson. 2016. Fountains and Water Vulture in Byzantium. Cambridge: Cambridge University Press.

Tapia, Stéphane de. 2006. “Entre Europe et Asie: Istanbul, cité cosmopolite, carrefour des diasporas?" Espaces, populations, sociétés 1: 167-179.

Tekin, Zeki. 1999. "Osmanlı Döneminde Dilencilik [Begging in the Ottoman Era]." Osmanlı V, 570-583. Istanbul.

Théodorides, Anna. 2016. "Survivre en context minoritaire: une étude sociologique des résistances des Grecs d'Istanbul (Rûms polites) au lendemain des émeutes de la nuit du 6 au 7 septembre 1955." Unpublished thesis, Paris EHESS.

Vryonis, Speros. 2005. The Mechanism of Catastrophe: The Turkish Pogrom of September 6-7, 1955 and the Destruction of the Greek Community of Istanbul. New York: Greekworks.com.

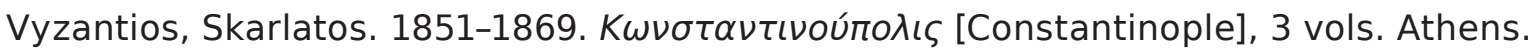

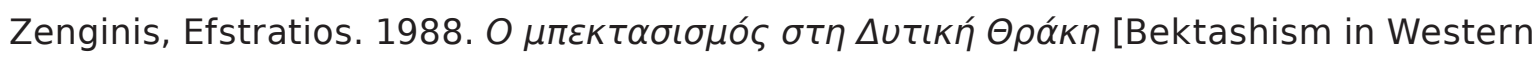
Thrace]. Thessaloniki: Institute for Balkan Studies. 


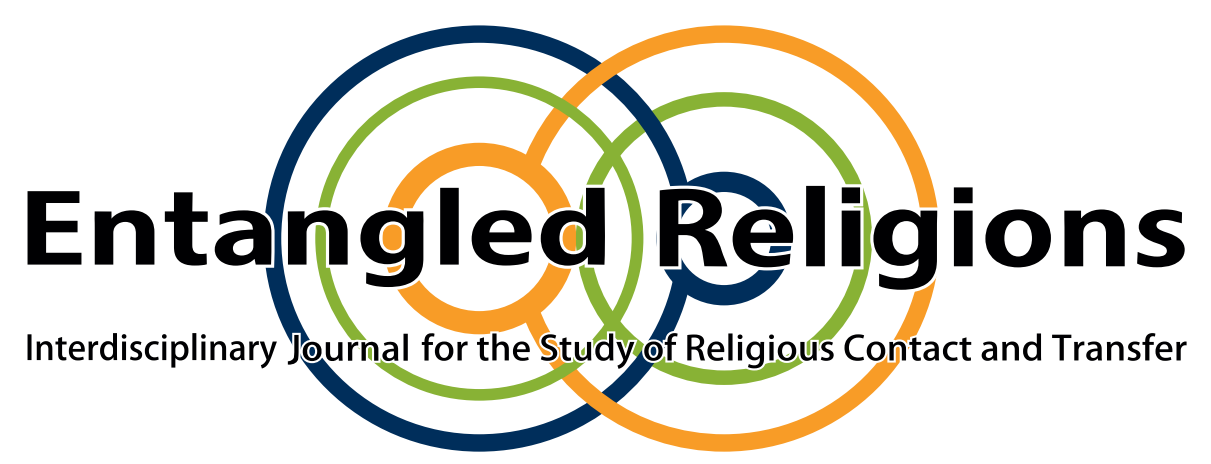

\section{A Muslim Holy Man to Convert Christians in a Transottoman Setting.}

Approaches to Sarı Saltuk from the Late Middle Ages to the Present

STEFAN ROHDEWALD

Insitute of History, Justus-Liebig-University of Gießen, Germany

This contribution to Entangled Religions is published under the Creative Commons Attribution 4.0 International Public License (CC BY 4.0 International). The license can be accessed at https://creativecommons.org/licenses/by/4.0/legalcode.

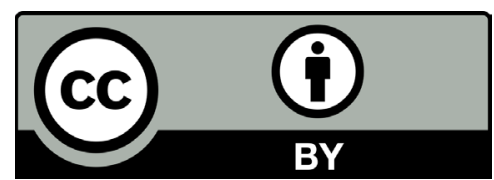

Entangled Religions 9 (2019) http://doi.org/10.13154/er.v9.2019.57-78
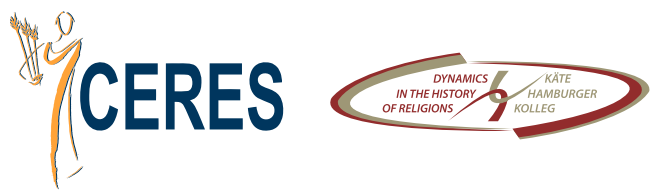

SPONSORED BY THE 


\title{
A Muslim Holy Man to Convert Christians in a Transottoman Setting.
}

\author{
Approaches to Sarı Saltuk from the Late \\ Middle Ages to the Present
}

STEFAN ROHDEWALD

Justus-Liebig-University of Gießen

\begin{abstract}
Interpretations of texts on Sarı Saltuk may serve as a central example of the entanglement of Muslim and Christian contexts in (south-)eastern Europe and the Near East. Analyzing the fifteenthcentury Saltuk-nâme and reports by Evliya Çelebi from the seventeenth century, a wide extension of the area concerned, as far as Poland-Lithuania, Muscovy and Sweden, can be observed. With the change of the contents of reports from the nineteenth and twentieth centuries, an increasing interest in Christians participating in the veneration of sites connected to Sarı Saltuk can be remarked. Yet descriptions of a veneration of Sarı Saltuk in a non-Muslim setting remain firmly embedded in Christian contexts, complicating a transreligious interpretation of them. In today's Turkish perspective, though, Sarı Saltuk is no longer contextualized in a manner encompassing Russia and Poland, too, but much more in a context focusing on and affirming national Turkish Anatolian or nationalized post-Ottoman contents in the Balkans.
\end{abstract}

KEY WORDS Muslim-Christian saint cult; common veneration; culture of memory; Sarı Saltuk; Central Asia; Anatolia; South Eastern Europe; Poland-Lithuania; Russia; Transottoman space

\section{Introduction}

This contribution deals with the Turkic Saint Sarı Saltuk and his veneration, which developed in southeast Europe. The analysis is based on the compilation called Saltukname (which contains popular legends and was compiled between 1473 and 1480, but the oldest manuscript is from 1591) and relevant passages in Evliya Çelebi's text. Moreover, research and sources on the twentieth century and contemporary veneration are discussed.

To some degree, new and inclusive approaches to Ottoman-European history between the sixteenth and eighteenth centuries, taking into account considerations of general early modern studies (Helmedach et al. 2014), can be pursued particularly based on the example of the saint cults: several saints in southeast Europe and Anatolia 
were venerated by both Christians and Muslims. Not only were St. Michael (Elsie 2002a, 218-19) and St. Petka or St. Venera (Çabej 1935, 568) revered by both Catholic and Orthodox Christians as well as by Muslims, but also-at least according to Serbian accounts-St. Sava (Rohdewald 2009). Moreover, the veneration contexts of Clement and Naum, two students of Cyril and Methodius, and in particular the veneration of the monastery dedicated to Naum at Lake Ohrid, have not been limited to Orthodoxy since the late Middle Ages (Naum) or since the twentieth century (Clement) (Rohdewald 2014, 366): The monastery church was said to be one of the tombs of the Muslim religious warrior Sarı Saltuk, who originated from Central Asia and who shall be the centre of focus here. In this article, I shall attempt to provide insight into the functions and interpretations of this cross-regional lieu de mémoire of Sarı Saltuk from the late Middle Ages up to the twenty-first century. In the discussion about the status of research as part of the culture of memory, I will at the same time present the various directions the interpretations of Sarı Saltuk have taken in academic discourse. Transliterations of Arabic or Ottoman terms appear in this contribution according to the quoted sources and, with few exemptions, have not been homogenized.

Since the fifteenth century, Sarı Saltuk (Entries in Encyclopedias: Babinger 1927; Kiel 2007; Leiser n.d.), who died in 1297/98 (697), has been considered the most popular of all the personages of the Bektashi Order of Dervishes (cf. Norris 2006, 57; Norris 1993; Norton 2001). However, Sunnis also attempted to appropriate the religious capital associated with him: According to the Saltuk-nâme compiled by Ebü'l-Hayr-ı Rûmî around 1480, Sarı Saltuk was a Sunni of the Hanefi legal school (Kaleshi 1971, 816). Many narratives were superimposed on him and conflated over several centuries and within a very large geographic region, which extended from Central Asia and Anatolia to southeast Europe, Russia and Asia Minor. These narratives ranged from depicting him as a shaman and religious warrior to depicting him as a saint (Norris 2006, 54). Nearly all aspects of his life are legendary and are present in quite varied traditions, the great majority of which are not contemporary. Possible clues to his "real" life disappear entirely in the background of these narrative reproductions of the tales, which are often limited to certain social situations and areas or places, but which at the same time refer to other geographic regions. He therefore appears as a supra-regional "religious figure of remembrance" (cf. Bahlcke, Rohdewald, and Wünsch 2013, especially xv-xxxiv for a methodological discussion) of the first order: Figures of remembrance, which are usually synonymous with places of remembrance, are metaphorically to be understood as discourses produced by the social group conveying them and thereby were also respectively altered (François and Schulze 2001, 18). "Figures of remembrance," in the sense of Jan Assmann, have a "concrete reference to time and space" as well as to a social group and are (re)produced anew in concrete practices (Assmann 2002, 38). 
Considering the geographical breadth the tales on Sarı Saltuk encompass, he is being considered here, too, as contributing to what might be called a Transottoman space of remembrance (cf. our German Research Foundation (DFG)-financed research priority program Transottomanica [www.transottomanica.de]and Rohdewald, Conermann, and Fuess 2019). ${ }^{1}$

\section{Sarı Saltuk: A Cunning Warrior-Saint in Anatolia, the Balkans and the Danube Delta Region}

According to extensive and numerous veneration texts, Sarı Saltuk, a native of Central Asia, played an important role in the spread of the Islamic faith and rule north and west of Constantinople and in southeast Europe in the thirteenth century. In particular, the warrior-saint is regarded to be responsible for the spread of Islam among the Tatars, led by Nogay, that took place beginning in 1260, on the south eastern borderlands of Rus' (Norris 2006, 57). Tales about and practices referring to Sarı Saltuk are thus to be interpreted as an exemplary lieu de mémoire in the multiple Byzantine-Frankish-SeljukOttoman contact zone in the eastern Mediterranean, which began to take form with the expansion of Catholic traders and crusaders as well as of Islam under the Seljuqs and the Rum-Seljuqs into Asia Minor, the Black Sea and, beginning in the thirteenth century, into southeast Europe in a stricter sense (Rohdewald 2011, 2014, 149f.). In exactly this context Sarı Saltuk is seen as having played a "mediating role" between Muslims and Christians when he led followers of 'Izz al-Dīn Kaykā'ūs, the Rumi-Seljuk sultan who took refuge with the Byzantines (Smith 1982, 225). Kaykā'ūs and other Rumi-Seljuk rulers of this time, who often had Byzantine wives or mothers who remained Christians, are described today as probably having had a double identity, Muslim and Christian, in a larger setting of Persian-Byzantine intermingling, especially at the courts of the ruling families (Shukurov 2012).

One of the oldest Arabic hagiographic texts about Sarı Saltuk is the work Tuffāh al-arwāḥ, completed in 715/1315 by Kamāl al-Dīn Muḥammad as-Sarāj al-Rifāì (Norris 2006 , 58). The main source for this text is said to be Bahram Şah al-Haydarî, who belonged to the small Sufi order of the Haydars, which, however, was widespread geographically in the late medieval period. The report thus appears older and more accurate than the famous and, of course, rather fictive travelogue by Ibn Battūta, created in the 1350s and describing the world, seen from an Arabic center, from Morocco to India, Central Asia and as far as Malaysia and China (Elger 2010; Kiel 2005,

1 For a general approach to aspects of the topic of this article, see Rohdewald 2017. 
286f.). According to Tuffāḥ al-arwāḥ, Saltuk was described as a warrior-saint. As leader of up to a thousand followers who attacked infidels, Saltuk appeared here as a figure who tore off his garments in a trance and who, in a second physical manifestation, fought against infidels and performed impressive deeds. For example, he caused the waters to disappear so that fish could be collected, as was told in tales recounted among Sufi disciples. He also freed one of the (Orthodox) Christians captured by the Catholic Franks-under the condition that he and his brother would become Muslims (Norris 2006, 59f.). Miracles that at first implicitly referred to Moses and Jesus, without being explicitly associated with them, were part of a conversion narrative in this text. According to the source, "Saltuk at-Turki was a miracle-working Dervish and lived in the city of İsakça in the country of Qıpçak. He died in 697 [1297/98] and was buried at the mountain where he had lived, some distance from İsakçe. His followers built a zaviye [small tekke, S.R.] around his tomb" (b. Isma'îl an-Nabhânî 1974, 100 f., quoted according to Kiel 2005, 286). The city of İsakçe, (in Romanian: Isaccea) was located west of Ak Kirman, according to the source. Kiel identified the mountain mentioned here as "Baba Mountain" (in Turkish: Babadağ). İsakçe is therefore probably the Bulgarian city of Oblučica during the Middle Ages, located on the lower Danube. İsakçe served Nogay Khan as a base for campaigns against the Bulgarian capital of Tărnovo. His conversion and that of his fellow combatants to Islam is attributed to Sarı Saltuk. These contexts of veneration and their connections to urban history have been studied thoroughly (Kiel 2005, 289).

Similar arguments were made in the Saltuk-name, compiled according to comparable epic tales in Ottoman and Persian around 1480: In this work, too, the theme of crossing religious boundaries was given great significance. Apparently, the hero was supposed to have been successful in the deception and persuasion in favour of Islam even in Constantinople: Sarı Saltuk travelled through Rumelia, disguised as a priest; toward Christians he pretended to be a traveller from Serbia and later an envoy of the Messiah. He gave a sermon in a church before the Christian prince, his lords and a prince of the Church (Saltuk-Nâme 1988-1990, 1: 35; cf. Krstić 2011: 69f.). The New Testament that he preached, however, was not the text known to the Christians but the "original, unchanged" text, which predicted another prophet after Jesus-as was customary in the Muslim, anti-Christian depiction: this text allegedly was older than the Christian text and falsified by it (Saltuk-Nâme 1988-1990, 1: 69f.; cf. Krstić 2011, 71f.). According to Tijana Krstić, this interpretation changed from "a potentially syncretic theme into an explicitly anti-syncretic one" $(2011,70)$. The missionary intention of the text exemplified the awareness of a distinct boundary to Christianity characteristic of that time.

The geographic range of activities reported on in this collection was already extraordinarily wide, encompassing Central Asia, mentioning hubs like Kashgar on 
the Silk road (Saltuk-Nâme 1988-1990, 2: 13) and Asia Minor, Mesopotamia as well as the Rus', Poland and Andalusia: The text starts with a passage about Cingis Khan, the conquest of Baghdad and the intention of the Seljuks to conquer Constantinople, i.e. (Eastern) Rome (Rûm: Saltuk-Nâme 1988-1990,1: 1f.). But not only Byzantium and Iraq, but also the "Franks", Rus' and Poland appeared here in an entanglement of competition and conflict: According to the narrative, Sarı Saltuk rode his horse "to the lands of Rus' ('Umlâk-i Rûsî)" until reaching Poland. In this context it is mentioned how he stamped on the tents of "Romans, the Rus', and the Franks" (Saltuk-Nâme 19881990, 1: 20). Shortly before dying, Sarı Saltuk reportedly commanded to send each ruler a coffin, each wishing to have Sarı Saltuk's corpse. Twelve of them were to be sent to Tuna Baba (Babadağ), Yılan Baba (Kaliakra), Edirne, Eski Baba (Babaeski), the steppe of the Kipchaks, Wallachia, Moldova, Rus', Hungary, Poland, Bohemia and Andalusia (cf. Anetshofer 2012, 303 and Saltuk-Nâme 1988-1990, 3: 299-302. Slightly different readings: Smith 1982, 219; Akalın 1998, 13; cf. Karamustafa 2012). This obviously fictive tale imagined a spatial expansion of the influence of the veneration of Sarı Saltuk into distant Christian and Muslim, Ottoman and non-Ottoman territories alike. Sites known later for the veneration of Sarı Saltuk in the Western Balkans, such as the monastery of Saint Naum, are missing in this and similar enumerations, however. Yet the compilation mentions the Balkans or south eastern Europe, as it reports on "the Serbs", "Bosnia (Bosna mülkine)", "Kosovo" and "Morea" (i.e. the Peloponnes)" (SaltukNâme 1988-1990, 1: 80, 142f., 2: 144f., 3: 364). Moreover, Anatolia played a role in this compilation-e.g. Amasya (Harcenevan) and Sivas are mentioned (Saltuk-Nâme 19881990, 1: 59, 93)-as well as Syria (Aleppo, Hamah, Damascus), Jerusalem, Mecca and Medina or Egypt (50-52, 94). Besides "infidels (Kâfirler)" or "Nazarenes (Nasrânîler)" (i.e. Christians), "Turks (Türkler)", "Jews (Yahûdî)" and Armenians are mentioned in missionary disputes on the true religion $(64,83)$. The veneration of Constantine the Great "from Rome, the city of Constantine (Rûm'dan Kostantîn şehrınden, Saltuk-Nâme 1988-1990, 1: 92)" is also part of the text as a fictional trip of Sarı Saltuk to France ("Firançe diyârına"), “Milan", Spain (“Espan") or Genoa (Saltuk-Nâme 1988-1990, 1: 99; cf. Aydoğan 2012, 110). The "Frankish stronghold" and later Genoese city of Caffa on Crimea, its closeness to the Rus' and, then, the Khanate of the Tatars were also incorporated into the broad geographical space of the narrative (Saltuk-Nâme 19881990, 1: 156), corroborating the cross-regional relevance of Crimea (Klein 2012).

This wide, imagined space of action gave the hero of the tale a crossregional or-for the late Middle Ages-a universal arena of veneration in a (post-)Byzantine, Ottoman or European setting. Heroic narratives on other fighters for Islam, as known in other Vilayet-Nâme (Anetshofer 2012, 292), contain passages on Sarı Saltuk told with different details-concerning the geographical extension of the mind map, as 
well: for instance, the HaCı Bektaş Velî Vilayet-Nâme explains how Sarı Saltuk went from Mount Arafat near Mecca to Sinope at the Northern Anatolian Black Sea Coast and from there to Georgia and then to Rum, i.e. Keliğra, setting him in the core Muslim region, and expanded into the Caucasus and the Black Sea hinterlands at the Danube (Manâkib-ı Hacı Bektâş-ı Veli 2005, 62-65). Therefore, with the narrative about Sarı Saltuk we arguably have access to descriptions of a very large, transcontinental and interreligious, yet beyond any doubt Muslim-dominated Ottoman mental map, which was reproduced by readers and listeners of the relevant tales.

\section{Sarı Saltuk as a "Christian Ascetic": Sunni Orthodoxy vs the Historicisation of Heterodoxy in the Early Modern Period}

It was not until after 1500 that the notion of Islamic orthodoxy changed in the Ottoman Empire and heresies were defined. According to Krstić, this is embedded in an overarching process of confessional consolidation, which took place in the early modern period both in Christianity and Islam (2011, 20). Krstić does not see any dichotomous division in the discussion of the confessionalisation thesis regarding the rivalling Christian and Islamic conversion narratives. Rather, in her research she found a close proximity and a high degree of interconnection in confessional homogenisation discourses: Ottoman texts of the sixteenth and seventeenth centuries regarding conversions resembled Catholic narratives of the same period, but the polemic rhetoric used in these advocated the supremacy of Islam (Krstić 2011, 166; 2008). Primarily as a direct polemic demarcation from the Shia Islam of the Safavids, the Sunni "orthodoxy was invented" (Dressler 2005, 155). The policy of strengthening Sunni Islam and the "social disciplinary" measures of Süleyman I were represented textually by the harmonisation of the imperial legal system, as was advocated by Ebussuud Efendi, i.e. to conflate the secular common law with Islamic law (Krstić 2011, 168; Imber 2009).

Not least, the practices commemorating Sarı Saltuk can be regarded at the core of this development: Like Sultan Bayezid II before him, Sultan Süleyman visited Babadağ in 1538 (Kaleshi 1971, 827). But unlike Bayezid, who established new endowments and thus institutionalized the veneration practices, Süleyman felt prompted by the tales about Sarı Saltuk to demand an expert opinion by Şeyhülislam Ebussuud, which was supposed to determine the orthodoxy of Sarı Saltuk, now appearing rather doubtful. The elements which appeared to be Christian in the already introduced conversion narratives apparently provoked doubt about this and also about the outcome of the legal opinion by Ebussuud, in which he stated that Sarı Saltuk was to be regarded as a 
"Christian ascetic" ("bir keşişdir", quoted from the fetva as in Okiç 1952, 56). Although it has been argued the fetva was a later forgery (Okiç 1952), the contrary is supported by better arguments (Yörükân 1952). Ebussuud consequently delegitimized the veneration of Sarı Saltuk as not orthodox Sunni but Christian, using the term "keşiş", which was commonly used only for Christian contexts. He denounced the intermingling comparable to the denominational, oldest meaning of 'syncretic': This term was first used in confessional polemic debates to condemn allegedly illegitimate entanglements.

\section{Sarı Saltuk in the Seventeenth Century: Evliya's Rhetoric Insistence on Poland, Bohemia and Russia}

Despite this new demarcation between a consolidated orthodoxy and heresy, Sarı Saltuk remained revered locally, at least as depicted in passages from the extensive, outstanding travelogue by Evliya Çelebi of around 1660. Evliya, who was by far the most important Ottoman travel writer of the seventeenth century (Tezcan, Tezcan, and Dankoff 2012), attempted to put Sarı Saltuk in a Sunni context: According to him, the "spiritual masters" in the convent near "Keliğra" or Kaliakra, where "the wooden sword of the saint" and other relics were kept, were orthodox Sunnis: "All are strict Sunnis, believers and monotheists, who perform the five daily prayers in their mosque" (quoted as in the translation by Dankoff and Kim 2010, 51. Cf. Hammer's English translation: Evliya 1850, 2: 72; original Ottoman text: Evliyâ 1896, 2: 138; modern Turkish translation: Evliyâ 2005, 2, part 1: 162f.). In fact, Evliya tried to revise the judgement by Ebussuud by disclaiming several times that Sarı Saltuk was "a priest named Saltik" (Anetshofer 2012, 293).

Several obviously fictive passages in the tale by Evliya are of central importance, both for a trans-religious interpretation as well as for an interpretation which recognizes an actually missionizing intention and only a pretension of the tale to be interreligious. This also concerns the revised, expanded geographic dimension of the imagination of Sarı Saltuk depicted in the text. Here, the convent in Babadağ was attributed to Sarı Saltuk under the subtitle "explanation of the Tekke of Keliğra Sultan or Sarı Saltık". On this occasion, Sarı Saltuk was introduced and his influence was elaborated directly in the context of successor of Hacı Bektaş Velî and Keliğra Sultan, who was, after having allegedly killed a patriarch of Danzig, identified as Sarı Saltık:

....after the conquest of the country of Rum [i.e. Anatolia],...Hacı Bektaş Velî and Keliğra Sultan went with 70 poor people into Muscovy and Poland, Bohemia and 
Dobruca...Hacı Bektaş gave Keliğra Sultan a wooden sword, a carpet, a drum, a banner, a flag, a kettle-drum and a trumpet.

Keliğra Sultan went, playing these intruments,

from Rum to Crimea, and from there to the people of Heşdek in Muscovy and Libka in Poland. In the port of Danzig (Danıska) in Poland he conversed with the patriarch Saint Nicholas, who was named Sarı Saltuk. Sarı Saltuk [i.e. Keliğra Sultan, S.R.] killed him, hid his body and went out of the church saying: 'I am Sarı Saltuk' and by this undercover means converted many thousands to Islam. Thus he travelled many years under the name of Sarı Saltuk, and being himself yellow-coloured (as Sarı Saltuk was) he obtained from Ahmed Yesevî the name of the yellow one."2 (Translation by S.R., cf. the original Ottoman text: Evliyâ 1998, 71 and Evliyâ 1896, 2: 133f.; the modern Turkish translation: Evliyâ 2005, 2, part 1: 158f.; cf. Hammer's old English translation: Evliya 1850, 2: 70)

Thus, Keliğra Sultan not only seemingly went to Russia, Poland-Lithuania and Bohemia, but also allegedly spoke with St. Nicholas, called Sarı Saltuk, in Danzig and killed him, adopting his name Sarı Saltuk. While this tale is easily recognisable as totally fictitious, the people of Heşdek in Muscovy and Lipka in Poland mentioned in the passage have a background in reality. Since the fourteenth century, Tatars (KulwickaKamińska and Łapicz 2013; cf. Kappeler 1988) had been in the service of Lithuania and, at the latest with the conquest of the Khanates of Kazan and Astrakhan, also partly in the service of Moscow: "Lipka" in Kipchak-Turkish means "Lithuania" (Kołodziejczyk 2011, 9).

But let's return to Evliya's narrative: Through deeds and miracles, Sarı Saltuk then succeeded in making the subjects of the King of the Dobruca convert to Islam. Shortly after this great success, Sarı Saltuk died, according to Evliya (Evliyâ 1998, 72).

Then, the travel writer used the apparently well-established framework of the narrative about Sarı Saltuk and broadened this geographically and fundamentally with respect to religion, even further than before, again obviously as fiction: Accordingly, in his last will Sarı Saltuk "ordered that seven coffins were to be prepared, because seven kings would lay claim to his body". Thus it supposedly happened-the "King of Muscovy" sent a coffin which was then sent back to Moscow with the body of Sarı Saltuk to be venerated in a "great türbe and a tekke". The same happened with the "King of Poland", who sent a coffin which was then sepulchered and venerated as "great 
türbe with a tekke" in Danzig. The "King of Bohemia" did the same and this third coffin was then displayed with the (third) body of Sarı Saltuk "great türbe with a tekke" in Pızovniçe [Pilsen?, S. R.]. More coffins came from the King of Sweden and the "King of Adrianople" as well as from and the "King of Moldova" and the ruler of Dobruca, and all of them brought back the coffin with a body of Sarı Saltuk, who was then venerated in a "great türbe and a tekke" at all these seven places. About the last place, Babadağ, Evliya added the information that this town entirely belonged to the endowments of Sarı Saltuk. Here Evliya constructed a space of religious memory extending far beyond the boundaries of the Ottoman Empire as a network of various coffins and tombs, of which "only three were located in the Empire". He expressly stated, finally, that Sarı Saltuk was revered "by Christians": "in Christian countries he is generally called St. Nicholas. All Christian nations venerate him greatly" (cf. the original Ottoman text: Evliyâ 1998, 73; Evliyâ 1896, 2: 136f.; the modern Turkish translation: Evliyâ 2005, 2, part 1: 161f.; Hammer's old English translation: Evliya 1850, 2: 71f.). Eventually, the author conceded that the conversion of Christians had not been completely successful; he was satisfied with describing an alleged subversion of their faith, which in his view became syncretic and partly Muslim or could be attributed to be under the roof of Islam by means of the veneration of Sarı Saltuk disguised or mistaken for St. Nicholas.

The widening and further elaboration of the older, shorter, already discussed narratives on Muscovy and Poland-Lithuania reflect the densification of the transregional or Transottoman communication of the Ottoman Empire, Poland-Lithuania and Muscovy as well as of the Crimean Khanate: All three major states and the Khanate were competing and intertwined through extensive, mutually claimed borderlands. The emphasis on the "Lipka Tatars" illustrates the awareness of a mutually intertwined history (Rohdewald 2016; Fisher 1998; Klein 2012), even if it is unknown whether Evliya knew about concrete texts, such as the risale-i tatar-i leh written in 1558 (Cf. Połczyński 2015). Frederick Hasluck holds that Nicholas was incorporated into this discourse because of his strong veneration among Bulgars and Russians (1929, II, 431). Moreover, Evliya seems to have adopted heroic narratives on other fighters for Islam as known in other Vilayet-Nâme, while having remained without knowledge of the Saltukname (Anetshofer 2012, 292). 


\section{Sarı Saltuk as St. Naum: Albania and Macedonia as Areas of Expansion of Saltuk's Veneration since the Nineteenth Century}

According to Nathalie Clayer, only the veneration of Sarı Saltuks in Krujë can be dated back to the sixteenth century $(2007,97)$. Already, Evliya mentioned (only) for Gjirokastër/Ergiri that followers of Ali, who all read Persian, venerated the feast of Sarı Saltuk (Evliya Çelebi 2000, 84f.). Thus, it was not until sometime after the spread of the alleged veneration of Sarı Saltuk to Muscovy, Poland-Lithuania, Bohemia and Sweden that the western regions of the "lands of Rum" were also elaborated on more extensively in the narrative.

It was not until reports of travellers in the nineteenth century that concrete names of places were mentioned in present-day Albania or in the historical landscape of Macedonia as well as in Bosnia and in Herzegovina, where alleged tombs of other saints were depicted as combined in their veneration with Sarı Saltuk (Hasluck 1914-1916, 85f.; Smith 1982, 223f.; Osmani 2012). It is this veneration which has been seen by leading researches as "syncretic". ${ }^{3}$ This alledgedly 'bottom up' expansion of transreligious or unconsciously syncretic veneration stated by Machiel Kiel is contrasted by the early interpretation of the same phenomenon as a conscious strategy, even "propaganda" by the Bektaşi to claim the sacral and social space of central Christian places and figures and appropriate them in the long term for Islam (Hasluck 1929, II, 437f.). Grace Smith formulated a compromise, combining both approaches in one sentence as possible options: "He was identified with Christian saints (S. Spyridon, S. Nicholas, S. Naum), the identification forced upon the people, if what Hasluck thinks is true, or else made naturally by the people who perceived strong similiarities between their origial saint and Sarı Saltuk" (Smith 1982, 225).

Unfortunately, we learn more concretely about practices only for the twentieth century, when they were reported about as observed and in use namely by the (Kosovo) Albanian classical Orientalist Hassan Kaleshi. He summarized the rather recent development in 1966 as follows:

The popularity of Sari Saltuk in the Balkans was so great-indeed it spread so intensively-that the number of seven supposed tombs in the original legends has long been surpassed. Besides these seven burial sites that Evliya Čelebi mentions, we must also mention Sari Saltuk's mausoleum in Blagaj, in Herzegovina, as well as a larger number of tombs in Kosovo and Metohija and in Albania, which we have 
already enumerated, as well as those on Corfu and Sveti Naum. One really has the impression that each city wanted to boast about having a mausoleum of Sari Saltuk. $(1971,828)$

Working in an ethnographic manner, too, he recorded and formulated the following information given by a local Muslim interviewee in the 1960s:

About two kilometres from Peć, in Kosovo-Metohija, at a place called 'Fusha e Zejnel Agës', there is a neglected tomb that people say is the tomb of Sarı Saltuk (Vorri $i$ Sari Saltukut). Here there used to be a mausoleum, the tomb itself was obscured. Under the roof of the mausoleum, there had also been a room which visitors came to and which was inhabited by the tomb keeper. Near this tomb there is also a second tomb, in which, about fifty years ago, the tomb keeper Šaih 'Abdī was interred. These tombs are visited by both Christians and Muslims. The Christians call it the tomb of St. Vasilije, and pilgrims come here and light their candles. They come daily, but on Tuesday there is the highest number of visitors. On the feast day of St. Elijah, the 'Ali Günü', the $2^{\text {nd }}$ of August, large numbers of the population undertake a pilgrimage here. The Rifāi-tekye has taken over the maintenance of the tomb. (Kaleshi 1971, 8174)

This quotation may be interpreted as giving evidence of a shared sacred place. But where does the sharing start and end, where does the mixing of religions begin, where is it delimited, and how do the participating people-either the interviewee or the researcher reporting his observation-perceive and contextualise the practices? From the point of view of one of the Christians mentioned, their veneration may probably just be meant for St. Vasilije and his tomb, which possibly would be described by them to be older than Sarı Saltuk and in no way connected to him. On the other hand, from the point of view of a Muslim, their veneration might be meant just for Sarı Saltuk and his tomb, which would probably be seen by them as not really the tomb of St. Vasilije, but only Sarı Saltuk's. The same might apply for St. Eliah (Christian perspective) and Ali (Muslim/Shia/Alevite perspective), respectively. Thus, while the same place is described here as venerated by Christians and Muslims, their reasons to venerate it might by very different, indeed mutually excluding the tale of the other group. The quotation gives actually no hint of a joint, Christian-Muslim faith in a shared narrative, very common to both groups, although both venerated the same grave. Contrariwise, the aim of both competing groups might rather be the appropriation of the sacred place for a

4 Translated from German to English by the author, as the other passages by Kaleshi to come in this contribution 
homogenous and exclusive veneration. Only if we knew more about the mentioned phenomena, such as the (jointly Christian-Muslim?) pilgrimage, could we judge in another way. The contribution to research intended by Kaleshi turns out to be open to manifold interpretations and to leave more questions open then answered. Related questions have been discussed with examples other than the practices of veneration of Sarı Saltuk (on "antagonistic tolerance" or "competitive sharing of religious sites", Hayden 2002, cf. the comments by Bowman 2010; Henig 2015; Albera and Couroucli 2012), who should remain in our focus here: In other passages of the contribution by Kaleshi, too, it is left up to the reader's imagination whether the interviewee reported by Kaleshi meant Christians and Muslims pilgrimaging to these places for the same reasons or for competing causes:

Since it was assumed that he was buried-some say in the Church of Saint Spyridon on Corfu, others say in the monastery of St. Naum in Ochrid-both Christians and Muslims pilgrimage there as if to a pilgrimage site. But since it is not exactly known which tomb is the right one, there are seven such pilgrimage sites to which people go on pilgrimages, convinced that it is precisely this tomb that is the true tomb of Sari Saltuk. $(1971,818)$

According to Kaleshi, tombs of Sarı Saltuk are moreover at

the Church of the Saint Spyridon on Corfu, and also Nahiye-Has, in the Paštrik Mountains (Bustrik); finally there is a tomb (türbe) of Ari Saltuk, and on the day of Ali Günü (i.e. on the feast day of St. Elijah) people undertake pilgrimages from Djakovica, Prizren and the surrounding Nahiyen to go there to be cured of ailments and diseases. Here sacrificial animals are also slaughtered. (Kaleshi 1971, 818)

Besides churches and a monastery, i.e. places claimed by Christians, at least one Muslim tomb called a türbe was mentioned, which initially must have been Muslim but was then secondarily also revered by Christians. The motivation of the visits, however, was to be cured, irrespective of religious affiliation. A known derivation of the name of Sarı Saltuk is associated with a cure from yellow fever, as Kaleshi mentions. What is decisive for the attractiveness of a saint's cult for believers, irrespective of their religion, was and is the prospect of benefitting from its healing power (Hasluck 1929, I, 68f.; cf. Duijzings 1993, 85), its 'sacred capital'. The veneration of grave sites appears to be oriented on the meagre basis of such reports on recovery or relief from everyday problems. 
One of the miracles supposedly wrought by Sarı Saltuk facilitated the plowing of a field, as the legends concerning Sarı Saltuk reveal, which were obtained from interviewees and recorded by Jean Deny around the year 1914. According to him, he was called "Chendaoun" in Albanian (by dissimilation for Chen Naum or Sveti Naoum; Deny 1920, 18f.). Also in this text, religious boundaries were crossed, and his worshippers were described as "everyone": "Tout le monde-chrétiens et musulmans-sont admis à le visiter et reçoivent l'hospitalité du monastère dont les revenus sont assurés par les 'vaqoufs' de Trpezica et Lyobanichta" (Deny, 1920, 18f.). His veneration in this rendering seemed monotheistic, without separating the Christian from the Muslim, as part of a single unified religion under a common roof of Islam and Christianity. This reception by a West European traveller and researcher also took place outside the control and steering of the Sufi fraternities, who acted in their self-perception as missionaries within the framework of the older texts that were still in use.

Ger van Duijzings mentions-initially independently of Sarı Saltuk-examples of religious veneration by Serbs and "Gypsy pilgrims" in the Gračanica monastery during the 1980s and 1990s, which apparently followed a similar, implicitly trans-religious logic (2000, 67-85). In contrast to the interpretation that (all) Muslims deliberately attempted to appropriate Christian sites, an interpretation which Duijzings shares in the context of the veneration of Sarı Saltuk $(2000,81)$, in my opinion the religious and political leaders who thought quite strategically should be highlighted. "Ordinary believers," however, who may not have been familiar with religious matters in detail, put the practical benefits-healing and problem solving as well as sociability-in the foreground (Duijzings 2000, 79). In a general framework, without reference to Sarı Saltuk, Duijzings is actually suggesting this interpretation: "Muslims and Christians of different ethno-religious backgrounds have visited each other's shrines, shared the veneration of certain saints and have often disregarded their priests' objections to the transgression of religious boundaries." (2000, 79, 84f., cf. 79f.)

The reading of the site at the monastery Saint Naum as a shared or mixed sacred place is correct in so far as Christians perceive it as a Christian site and Muslims perceive the same site as a Muslim site. But I did not find immediate or primary sources confirming the mixture of both faiths or a transreligious, monotheistic practice beyond the affirmation of one of them.

The interpretation of a fresque in the Church as showing Sarı Saltuk is common (only) among Muslims, too:

The large number of Muslim visitors to this shrine, especially at the tomb of Saint Naum, is due to their belief that the face of Saint Naum in the painting entitled 'Saint Naum Reins in a Bear Instead of an Ox' actually belongs to the Bektashi saint, 
Sar' Salt'k. The two-wheeled chariot in which St Naum sits is pulled by a deer and a lion, which are traditional Bektashi animal symbols. (Filipova 2014, 7)

Moreover, the closeness of this and other legends on Sarı Saltuk to those about Hızır, a helping immortal personage, are stressed (Filipova 2014, 7; cf. Döğüş 2015).

Yet from a Christian point of view, the cart drawn by an ox and a bear instead of by two oxen, exclusively represents one of the Christian legends about Saint Naum as known from other places in the region, and certainly not Sarı Saltuk, who remains unmentioned in this text ("Predanija" 2017).

Thus, in relation to this and similar examples it is not adequate-and a wrong reading of Babinger's short entry on Sarı Saltuk in the Encyclopedia of Islam, quoted as source of this claim - to pronounce that he was

(...) strongly venerated by the Christians in the region. Especially the Macedonian and the Bulgarian people, being Orthodox Christians, venerated [him] as Saint Nicholas, Saint Spiridon, Saint Naum and later (...) added Saint Georges, Saint Elyah, and [set him] in place of Saint Simeon and Saint Koncolos [?]. ${ }^{5}$ (Hodža 2015,

12)

Although Babinger made the point that one may see Sarı Saltuk as a "one of the most remarkable features in the mingling of Muslim and Christian beliefs", he mentioned just Muslim texts and contexts of veneration, but no Christian examples $(1927,173)$.

The interest in connecting St. Naum's monastery or Clement to Sarı Saltuk and, thus, Islam, was just another expression of the large attraction of their 'sacral capital' in the context of competing discourses on the appropriation of the historical region of Macedonia these sites represented. In Serbian (referring to the region as South Serbia), Bulgarian (describing the region as Western Bulgaria or Bulgarian Macedonia) and later Macedonian national projects, the history of orthodox Christianity and especially these local saints played an absolutely pivotal role as lieux de mémoire used for the consolidation and featuring of nationalised religious and historical narratives (extensively: Rohdewald 2014).

In today's Turkish perspective, Sarı Saltuk is no longer contextualized in a manner encompassing Russia and Poland but much more in a context focusing on and affirming national Turkish Anatolian (Döğüş 2015) or nationalized post-Ottoman contents in the Balkans (Akalın 1998). As part of this development, the inclusion of Christian narrative elements into the tales and their analysis decreased to a large extent. According to an

5 English translation by author. 
anonymous Turkish visitor to the place (with a photograph of the tomb in question) in 2015, visits by Muslims have seemingly decreased today, as he writes on an internet blog, due to their emigration after the breakup of the Ottoman Empire. The sameobviously casual-visitor actually denounced the Muslim perspective and narratives about the grave of Sarı Saltuk being in the Monastery, as the latter is, in his eyes, an exclusively Christian place, without any hints which might possibly be interpreted as Muslim: "If it remains to me to judge, I think the tale that here was a grave of Sar Saltuk is an exemplary legend, as inside the church I could not see anything hinting at something belonging to a Muslim grave." ("Balkanlarda“ 2015) ${ }^{6}$

\section{Conclusion}

Interpretations of texts on Sarı Saltuk may serve as a central example of the entanglement of Muslim and Christian contexts in (south-)eastern Europe, Central Asia and Anatolia: The narratives related to Sarı Saltuk show the extension of a 'Transottoman' context expanding across a vast geographical space encompassing Arabia, Anatolia, Georgia, Poland-Lithuania, Muscovy, Sweden and the Balkans. The identification of Sarı Saltuk with St. Nicholas, which was already observed in the passages by Evliya regarding the veneration in the Danube delta region, was taken up in the context of the Balkans and transferred into new geographic regions.

Setting these examples together as a spacial network, the tales on Sarı Saltuk trace a Transottoman map, clearly expanding beyond the Ottoman Empire itself. The mixing of "Christian elements" into the Muslim texts was read as a contamination of Islam in the sixteenth century, given that the logic of the texts aimed at convincing Christians to converse to Islam - with the fatwa by Ebussuud Efendi, which meant it to be syncretic in the old, denominational sense. Modern researchers, then, described it as religious propaganda (Hasluck 1929) or syncretism from below (Kiel 2000, 283).

With the change of the contents and contexts of reports and more details observed regarding concrete sites since the nineteenth and twentieth centuries, an increasing observation of Christians participating in the veneration of sites connected to Sarı Saltuk, too, can be remarked. Yet available contemporary descriptions of a veneration of these sites in a non-Muslim setting remain firmly embedded in Christian contexts, omitting Sarı Saltuk, not allowing a transreligious interpretation of them. Thus, the reading of the analyzed examples as shared or mixed sacred practices or sites is in so far correct as Muslims (authors and/or other participants) see the presented context 
as Muslim while Christians (authors and/or other participants) see the same context as Christian. The examples about Sarı Saltuk discussed here, however, do not allow or confirm the observation of mixture of both faiths or a transreligious, monotheistic phenomenon beyond the affirmation of one of them.

Finally, a nationalization of Sarı Saltuk can be observed: In today's Turkish perspective, Sarı Saltuk is no longer contextualized in a manner encompassing Russia and Poland, but much more in a context focusing on and affirming national Turkish Anatolian or nationalized post-Ottoman contents in the Balkans.

\section{Bibliography}

\section{Primary Sources}

“Balkanlarda bir inci: Ohrid." 2015. Accessed February 20, 2019. http://kendingez.com/ balkanlarda-bir-inci-ohrid-gezi-yazisi.

Deny, Jean. 1920. Traditions populaires turqes de Salonique et de Florina. Niort: Imprimerie nouvelle G. Clouzot.

Evliyâ Çelebi. 1896. Seyahatnâme, vol. 2. Constantinople.

-—- 1998. Seyahatnâmesi, Evliyâ Çelebi b. Derviş Mehemmed Zıllî. II. Kitap Topkapı Sarayı Kütüphanesi Bağdat 304 Numaralı Yazmanın Transkripsiyonu, edited by Zekeriya Kurşun, Seyit Ali Kahraman, and Yücel Dağlı. İstanbul: YKY.

- - 2000. Evliya Çelebi in Albania and Adjacent Regions (Kosovo, Montenegro, Ohrid). The Relevant Sections of the Seyahatname, edited by Robert Dankoff and Robert Elsie. Leiden: Brill.

_-_. 2005. Günümüz Türkçesiyle Evliyâ Çelebi Seyahatnâmesi, edited by Yücel Yücel Dağlı and Seyit Ali Kahraman. İstanbul: YKY.

-_- 2010. An Ottoman Traveller. Selections from the Book of Travels of Evliya Çelebi. Translation and Commentary by Robert Dankoff and Sooyong Kim. London: Eland.

Evliya Efendi. 1850. Narrative of Travels in Europe, Asia, and Africa, in the Seventeenth Century. Translated from the Turkish by the Ritter Joseph von Hammer. London: Printed by William Nicol.

“Predanija i legendi za Sveti Naum Ohridski Čudotvorec." 2017. http://ohridpress.com. $\mathrm{mk} / \mathrm{p}=70237$.

Saltuk-Nâme. 1988-1990. Edited by Şükrü Halûk Akalın, 3 vols. Ankara: Gençlik Basımevi. 
Manâkib-ı Hacı Bektâş-ı Veli “Velâyetname”. 2005. The Saintly Exploits of Haji Bektash Veli. Translated by Huseyin Abiva. Babagân Press.

Yusuf ibn Isma'îl an-Nabhânî. 1974. Jami Karamat al-Awliya, vol. 2. Cairo.

\section{Secondary Sources}

Akalın, Şükrü Hâlûk. 1998. "Sarı Saltuk'un Türbe ve Makamları Üzerine." In I. Uluslararası Türk dünyası eren ve evliyaları kongresi bildirileri, 9-28. Ankara: Ervak Yayınları. Anetshofer, Helga. 2012. "Legends of Sarı Saltuk in the Seyahatnâme and the Bektashi Oral Tradition." In Evliyâ Çelebi. Studies and Essays Commemorating the 400th Anniversary of his Birth, edited by Nuran Tezcan, Semih Tezcan, and Robert Dankoff, 296-304. Ankara: Republic of Turkey Ministry of Culture and Tourism Publications.

Aydoğan, Zeynep. 2012. "Creating an Ideal Self. Representations of Infidels in the Late Medieval Anatolian Frontier." Osmanlı Araştırmaları/The Journal of Ottoman Studies 40: 101-119.

Albera, Dionigi, and Maria Couroucli, eds. 2012. Sharing Sacred Spaces in the Mediterranean. Christians, Muslims and Jews at Shrines and Sanctuaries. Bloomington: Indiana University Press.

Assmann, Jan. 2002. Das kulturelle Gedächtnis: Schrift, Erinnerung und politische Identität in frühen Hochkulturen. München: Beck.

Babinger, Franz. 1927. "Șari Șalțiḳ Dede." In The Encyclopaedia of Islam, vol. 7, edited by Martijn Theodoor Houtsma, 171f. Leiden: Brill 1927.

Bahlcke, Joachim, Stefan Rohdewald, and Thomas Wünsch, eds. 2013. Religiöse Erinnerungsorte in Ostmitteleuropa: Konstitution und Konkurrenz im nationenund epochenübergreifenden Zugriff. Berlin: Akademie.

Bowman, Glenn. 2010. “Orthodox-Muslim Interactions at 'Mixed Shrines' in Macedonia." In Eastern Christians in Anthropological Perspective, edited by Chris Hann and Hermann Goltz, 195-219. Berkeley: University of California Press.

Çabej, Eqrem. 1935. "Sitten und Gebräuche der Albaner." Revue internationale d'études balkaniques 1: 556-572.

Clayer, Nathalie. 2007. Aux origines du nationalisme albanais. La naissance d'une nation. Paris: Karthala.

Dressler, Markus. 2005. "Inventing Orthodoxy: Competing Claims for Authority and Legitimacy in the Ottoman-Safavid Conflict." In Legitimizing the Order. The Ottoman Rhetoric of State Power, edited by Hakan Karateke and Maurus Reinkowski, 151-176. Leiden: Brill. 
Döğüş, Selahattin. 2015. "Anadolu'da Hızır-ilyas kültü ve Hıdrellez geleneği." Türk Kültürü ve Hacı Bektaş Velî Araştırma Dergisi 74: 77-100.

Duijzings, Ger. 1993. "Pilgrimage, Politics and Ethnicity. Joint Pilgrimages of Muslims and Christian and Conflicts over Ambigious Sanctuaries in Yugoslavia and Albania." In Power and Prayer. Religious and Political Process in Past and Present, edited by Mart Bax and Adrianus Koster, 79-90. Amsterdam: VU University Press.

- - . 2000. Religion and the Politics of Identity in Kosovo. New York: Columbia University Press.

Elger, Ralf. 2010. “Lying, Forging, Plagiarism: Some Narrative Techniques in Ibn Battuta's Travelogue." In Many Ways of Speaking about the Self. Middle Eastern Ego-Documents in Arabic, Persian and Turkish (14th-20th century), edited by Ralf Elger and Yavuz Köse, 71-88. Wiesbaden: Harrassowitz 201.

Elsie, Robert. 2002. Handbuch zur albanischen Volkskultur. Mythologie, Religion, Volksglaube, Sitten, Gebräuche und kulturelle Besonderheiten. Wiesbaden: Harrassowitz.

Fisher, Alan. 1998. Between Russians, Ottomans and Turks. Crimea and Crimean Tatars. Istanbul: The Isis Press.

Filipova, Snežana. 2014. "Notes on the Continuous Multi-Confessional Use of Shrines, Cult Places, Christian Relics and Springs of Holy Water in the Republic of Macedonia." Systasis 25 (1). http://www.systasis.org/pdfs/systasis_25_1.pdf.

François, Etienne, and Hagen Schulze. 2001. "Einleitung." In Deutsche Erinnerungsorte, edited by François Etienne and Hagen Schulze, vol. 1, 9-24. München: Beck.

Hasluck, F[rederick]. W. 1914-1916. "Geographical Distribution of the Bektashi." The Annual of the British School at Athens 21: 84-124.

-_- 1929. Christianity and Islam under the Sultans, 2 vols. Oxford: At The Clarendon Press.

Hayden, Robert. 2002. "Antagonistic Tolerance: Competitive Sharing of Religious Sites in South Asia and the Balkans." Current Anthropology 43 (2): 205-231.

Helmedach, Andreas, Markus Koller, Konrad Petrovszky, and Stefan Rohdewald, eds. 2014. Das osmanische Europa. Methoden und Perspektiven der Frühneuzeitforschung zu Südosteuropa. Leipzig: Eudora.

Henig, David. 2015. "Contested Choreographies of Sacred Spaces in Muslim Bosnia." In Choreographies of Sacred Spaces. Religion and Conflict Resolution, edited by Elazar Barkan and Karen Barkey, 130-160. New York: Columbia University Press.

Hodža, Fadil. 2015. "Važnost na legendite i predanijata vo vrska so Sari Saltik vo istorijata na islamskata kultura na Balkanot." Hikmet 13/26 (2): 8-29. 
Imber, Colin. 2009. Ebu's-su'ud. The Islamic Legal Tradition. Stanford: Stanford University Press.

Kaleshi, Hasan. 1971. "Albanische Legenden um Sari Saltuk." In Actes du Premier Congrès International des Etudes Balkaniques et Sud-Est-Européennes, Sofia 26 août-1 septembre, 1966, vol. 7: Littérature, ethnographie, folklore, edited by Vladimir I. Georgiev, Nikolaj T. Todorov, and Vasilka Tăpkova-Zaimova, 815828. Sofia: Ed. de l'Acad. Bulgare des Sciences.

Kappeler, Andreas. 1988. Rußlands erste Nationalitäten. Das Zarenreich und die Völker der Mittleren Wolga vom 16. bis 19. Jahrhundert. Köln: Böhlau.

Karamustafa, Ahmet T. 2012. "Islamisation through the Lens of the Saltuk-name." In Islam and Christianity in Medieval Anatolia, edited by A.C.S. Peacock, Bruno De Nicola, and Sara Nur Yıldız. Farham, 349-364. Surrey: Ashgate.

Kiel, Machiel. 2000: "Sarı Saltuk: Pionier des Islam auf dem Balkan im 13. Jahrhundert." In: Aleviler / Alewiten. Kimlik ve Tarih / Identität und Geschichte, edited by Ismail Engin and Erhard Franz, 253-286. Hamburg: Deutsches Orient-Institut Hamburg.

- - . 2005. "Ottoman Urban Development and the Cult of a Heterodox Sufi Saint. Sarı Saltuk Dede and Towns of İsakçe and Babadağ in the Northern Dobrudja." In Syncrétismes et hérésies dans l'Orient seldjoukide et ottoman (XIVe-XVIIIe siècle. Actes du Colloque du Collège de France, octobre 2001, edited by Gilles Veinstein, 283-298. Paris: Peeters.

_-_. 2007. "Sarı Saltuk." In: Türkiye Diyanet Vakfı İslâm Ansiklopedisi, vol. 36, edited by Bekir Topaloğlu, 147-150. İstanbul: Türkiye Diyanet Vakfı İslâm Araştırmaları Merkezi.

Klein, Denise, ed. 2012. The Crimean Khanate between East and West (15th-18th Century). Wiesbaden: Harrassowitz.

Kołodziejczyk, Dariusz. 2011. The Crimean Khanate and Poland-Lithuania. International Diplomacy on the European Periphery (15th-18th Century). A Study of Peace Treaties Followed by Annotated Documents. Leiden: Brill.

Krstić, Tijana. 2008. "Illuminated by the Light of Islam and the Glory of the Ottoman Sultanate: Self-Narratives of Conversion to Islam in the Age of Confessionalization." Comparative Studies in Society and History 51: 35-63.

--_. 2011. Contested Conversions to Islam. Narratives of Religious Change in the Early Modern Ottoman Empire. Stanford: Stanford University Press.

Kulwicka-Kamińska, Joanna, and Czesław Łapicz, eds. 2013. Tatarszy Wielkiego Księstwa Litewskiego w historii, języku i kulturze - Tatary Velikogo knjažestva Litovskogo $v$ istorii, jazyke $i$ kul'ture - The Tatars of the Grand Duchy of Lithuania in History, Language, and Culture. Torun. 
Leiser, Gary. n.d. "Șari Șalțūḳ Dede." In Encyclopaedia of Islam. 2nd ed., edited by P. Bearman, Th. Bianquis, C.E. Bosworth, E. van Donzel, and W.P. Heinrichs. Accessed February 18, 2019. http://dx.doi.org/10.1163/1573-3912_islam_ SIM_6646.

Norris, Harry T. 1993. Islam in the Balkans. Religion and Society between Europe and the Arab World. Columbia: University of South Carolina Press.

- - . 2006. Popular Sufism in Eastern Europe. Sufi Brotherhoods and the Dialogue with Christianity and 'Heterodoxy'. London: Routledge.

Norton, John. 2001. "The Bektashis in the Balkans." In Religious Quest and National Identity in the Balkans. Studies in Russia and East Europe, edited by Celia Hawkesworth, Muriel Heppell, and Harry Th. Norris, 168-200. London: Palgrave.

Okiç, M. Tayyib. 1952. "Sarı Saltuk'a ait bir fetva." Ankara Üniversitesi Ilahiyat Fakültesi Dergisi 1 (1): 48-58.

Osmani, Edlira. 2012. “God in the Eagles' Country: The Bektashi Order." Quaderns de la Mediterrània 17: 107-116.

Połczyński, Michael. 2015. "Seljuks on the Baltic: Polish-Lithuanian Muslim Pilgrims in the Court of Ottoman Sultan Süleyman." Journal of Early Modern History 19: 409-437.

Rohdewald, Stefan. 2009. “'Der heilige Sava und unsere Muslime'-Albanische, türkische bzw. muslimische Verehrung christlicher Heiliger aus serbischer und bulgarischer Perspektive (20. Jahrhundert)." In Muslime und Christen. Interethnische Koexistenz in südosteuropäischen Peripheriegebieten. Religionsund Kulturgeschichte in Ostmittel- und Südosteuropa, vol 12, edited by Thede Kahl and Cay Lienau, 155-172. Münster: LIT.

_-_. 2011. "Kyrill und Method, Kliment und Heilige in der neuen 'Zarenstadt' Tărnovo: (Trans)Kulturelle Praktiken der Heiligenverehrung im Wandel von der slawisch-byzantinischen zur slawisch-osmanischen Kontaktzone." Quaestiones Medii Aevi Novae 16, Frontiers and Borders in Medieval Europe, edited by Andrzej Janeczek: 203-234.

--_. 2014. Götter der Nationen. Religiöse Erinnerungsfiguren in Serbien, Bulgarien und Makedonien bis 1944. Visuelle Geschichtskultur. Wien: Böhlau.

_-_. 2016. “'bu sulh u salah mukarrer ve mü'ebbed'/'Pax perpetua.' Polnischlitauische Friedensformeln und Allianzen mit Osmanen und Krimtataren bis 1790." Zeitschrift für Ostmitteleuropaforschung (65) 2, Polnisch-osmanische Verflechtungen in Kommunikation, materieller Kultur, Literatur und Wissenschaft, edited by Hans-Jürgen Bömelburg, Stefan Rohdewald, and Dirk Uffelmann, 167-192. 
_-_. 2017. "Sarı Saltuk im osmanischen Rumelien, der Rus' und Polen-Litauen. Zugänge zu einer transosmanischen religiösen Erinnerungsfigur (14.-20. Jh.)." In Heilig. Transkulturelle Verehrungskulte vom Mittelalter bis in die Gegenwart, edited by Kerstin Jobst, Dietlind Hüchtker, 67-98. Göttingen: Wallstein.

Rohdewald, Stefan, Stephan Conermann, and Albrecht Fuess, eds. 2019. Transottomanica: Osteuropäisch-osmanisch-persische Mobilitätsdynamiken. Perspektiven und Forschungsstand. Göttingen: Vandenhoeck \& Ruprecht Unipress.

Smith, Grace M. 1982. "Some Türbes/Maqāms of Sarı Saltuq. An Early Anatolian Turkish Ġāzī-Saint." Turcica 14: 216-225.

Shukurov, Rustam. 2012. "Harem Christianity. The Byzantine Identity of Seljuk Princes." In: The Seljuks of Anatolia. Court and Society in the Medieval Middle East, edited by Andrew C.S. Peacock and Sara Nur Yıldız, 115-150. London: I.B. Tauris.

Tezcan, Nuran, Semih Tezcan, and Robert Dankoff, eds. 2012. Evliyâ Çelebi. Studies and Essays Commemorating the 400th Anniversary of his Birth. Ankara: Republic of Turkey Ministry of Culture and Tourism Publications.

Yörükân, Yusuf Ziya. 1952. “Bir Fetva Münasebetiyle. Fetva Müessesesi, Ebussuud Efendi ve Sarı Saltuk." Ankara Üniversitesi ilahiyat Fakültesi Dergisi 1/2 (3): 137-150. 


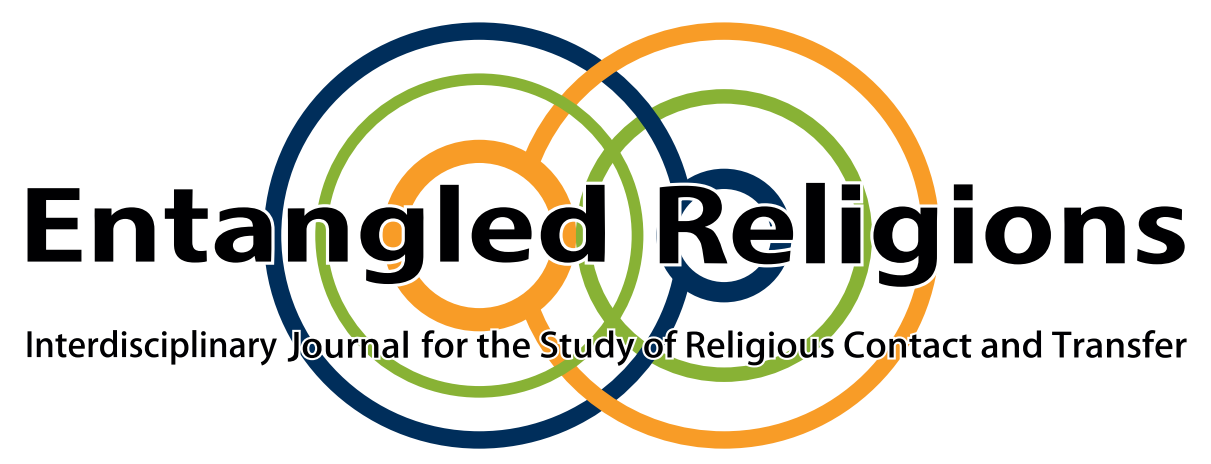

\section{Spirit of Place and Nation Building.}

Kosovo and Bosnia from Imperial to Post-Communist Times

TANJA ZIMMERMANN

Insitute of Art History, Universität Leipzig, Germany

This contribution to Entangled Religions is published under the Creative Commons Attribution 4.0 International Public License (CC BY 4.0 International). The license can be accessed at https://creativecommons.org/licenses/by/4.0/legalcode.

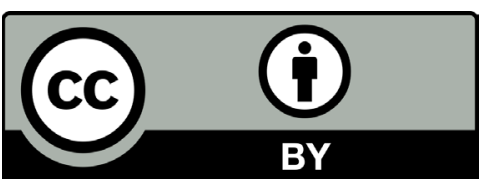

Entangled Religions 9 (2019) http://doi.org/10.13154/er.v9.2019.79-107
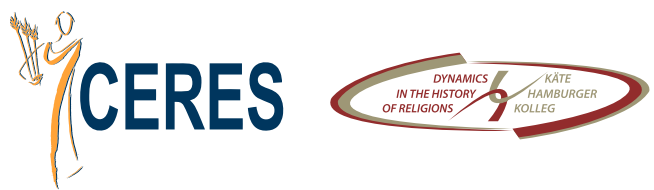

SPONSORED BY THE 


\title{
Spirit of Place and Nation Building.
}

\author{
Kosovo and Bosnia from Imperial to Post-Communist Times
}

\author{
TANJA ZIMMERMANN
}

Universität Leipzig

\begin{abstract}
During the period of nation building, the spirit of place (genius loci), attributing uniqueness to specific locations and ascribing to them close attachment to the nation, became a central vehicle for defending and appropriating territories and even for establishing a diaspora in exile. It was evoked through discursive practices reminiscent of religious rhetoric and around monumental works of art, thereby staging history as mythical sacred theatre. The process of establishing imagined national geographies during the long period of nation building from the nineteenth century to the post-communist period is analysed in comparative perspective in two multi-religious and multi-ethnical regions in southeast EuropeKosovo and Bosnia. The leading question I will try to answer is why the Field of Blackbirds in Kosovo was successfully established as a national holy place in the collective memory of the Serbs, whereas similar efforts in Bosnia did not result in inscribing mythic places into national memory.
\end{abstract}

KEY WORDS Spirit of place; nation building; religion; nationalism; Bosnia; Bogumils; the Field of Blackbirds; Kosovo polje; Kosovo

\section{Introduction: The Spirit of Place and Nation Building}

Since Antiquity, the spirit of place (genius loci) has described the uniqueness of a location, attributing to it a specific atmosphere and character which awakens strong moods and feelings of coherence in people visiting them (Kozljanič 2004, 145-148; Valena 2009). Containing material, visible elements (such as geological formations, flora and fauna, etc.) as well as immaterial, invisible components which evade precise determination (experience of energy, power or mystery), the spirit of place qualifies a landscape and its population as an area marked by a specific geomantic, phenomenological and religious energy. In Roman Antiquity, it described a place inhabited and protected by a family clan and the spirit of its ancestors or a location of some other community (a military camp, a village or a city) protected by specific deities (Kozljanič 2004, 27-148). In the Christian period, the spirit of place was split into its demonic and its sacred aspects (ibid., 271-407). Demonic places were mostly linked to the old pagan cults, whereas locations linked to re-appropriated Jewish or to new Christian events were marked by their sacred spirit: Places known from the Bible 
or where saints had lived and died were inscribed into an imaginary geography marked by new spiritual needs and performative religious practices (Halbwachs 2003, 154-211). The earth touched by their feet as a relic of place was believed to be sacred, although it contained no visible traces of historical events and although these took place at other locations or were simply legend (Koch and Schlie 2016).

During the period of nation building in the nineteenth and early twentieth centuries, the spirit of place was extended from single spots to whole landscapes, incorporating the collective memory of a nation, like famous battlefields, or natural borders between nations, such as forests, rivers and mountains (Warnke 1992; Schama 1995; Lipták 2003; Cronin 2015, 14-21). The first became places of national memory, the second national frontiers. Whereas places of memory were revived by the care for tradition and its social routine, such as remembrance rituals, national frontiers were defined by imaginary close bonds between nature and the people living there (Giesen 2016). ${ }^{1}$ Their relationship was not determined by a memory of the past attached to the place, but by an intensive experience of the space in the present. Nature was believed to inscribe itself into physiognomy, character and habits of people, who in return gave it the imprint of their work and culture. The idea of a close relation between people and nature had its roots in the romantic landscape, which served as a space for the projection of inner emotions and of national character (Hübner 1985, 349-352). It was also formed by Hippolyte Taine's (1828-1893) milieu theory, which postulated an interconnectedness of "race" (understood close to the German "Volksgeist"-genius of the nation), denoting physical, psychological and moral characteristics, of "milieu", describing the physical environment as well as social and political circumstances, and of "moment" (being close to the German "Zeitgeist"), meaning historical processes (Wellek 1959). Taine's and other milieu theories adopted and updated the legacy of theories of climate dating from antiquity and reinvigorated during the eighteenth century. Both places of memory and national frontiers were elevated to the status of natural temples of the nation and became a symbol of its identity. Religious rhetoric and pathos were transposed into a secularized context so that they could express emotional attachment to the homeland through nature. A landscape accommodating the spirit of place was less an idyllic, lovely location (a locus amoenus) than a frontier challenging human power and demanding tribute for regularly renewing close bonds

1 The sociologist Bernhard Giesen calls such collectives, being closely related to nature, primordial. They manifest in processes of nation building but also of nationalism, which aggressively strikes far beyond the love for the homeland. Members of primordial communities naturalize cultural similarities as innate, inscribed in the body, and perceived them as timeless and unchangeable. Such collectives draw sharp, impassable boundaries between their own community and the Other, so they barely allow an inclusion. 
with it $^{2}$-similar to the death toll Christian martyrs had to pay for their loyal attachment to their religious faith.

When milieu and racist theories of the nineteenth century culminated in the "bloodand-soil" ideology of the Nazis, the mythical spirit of place provided the compatriots who believed in the mission of racially purifying with spiritual and physical powers that arose from its telluric depth. One of the leading landscape and portrait photographers of the Third Reich, Erna Lendvai-Dircksen (1883-1962), writes in an introduction to her book of photographs Mountain People (Bergmenschen, 1936) about the mutual penetration of the land and the people manifesting in their physiognomy and habit:

Just look at them: our high mountain dwellers. They are steep: the back of their head, the nose, the chin, the gaze, the posture, the walk....They are all their own landscape: craggy and cracked like the old mountains, grown old by the harsh weather of time; quick-tempered like wild streams of snow water in spring; in their eyes the bright power of mountain flowers. Here it is: the face of the landscape in the landscape of the face. ${ }^{3}$ (Lendvai-Dircksen 1936, unpaginated) ${ }^{4}$

In her photo book The Face of the German East (Das Gesicht des deutschen Ostens, 1937) she compares the power of natural forces in Saxony with the conquest of the German settlers, whose 'urge to the east' is depicted as an almost cultic approach to the rising sun:

Dark harmony in minor is sprinkled by the light of the northern face; the violence of the rhythms of feeling, fresh natural forces form and shape the face of the German East. Blood flows of all tribes of the empire surged in the waves of the centuries against the strangeness that crowds out of the giant eastern areas. Good, best

2 Mountains, which were especially glorified in German films of the 1920s and 1930s, such as Arnold Fanck's The Holy Mountain (1926) or Leni Riefenstahl's The Blue Light (1932), merged with the elementary spirit of its people who died in their gorges.

3 Unless indicated otherwise, all translations from German to English throughout the article are by the author.

4 “Man sehe sie an: unsere Hochgebirgler. Sie sind steil. Der Hinterkopf, die Nase, das Kinn, der Blick, die Haltung, der Gang....Sie waren alle ihre Landschaft selbst. Schroffschrundig, wie die alten Berge, alt geworden in den Wettern der Zeit. Aufbrausend, wie der Wildbach im Schmelzwasser des Frühlings. In den Augen die Leuchtkraft der Bergblumen. Hier ist es: das Gesicht der Landschaft in der Landschaft des Gesichts.“ 
people's force of German lands searched and found their living space in the open East, towards the rising sun. (Lendvai-Dircksen 1937, unpaginated). ${ }^{5}$

In her later photographic book Migrating Dunes (Wanderdünen, around 1940), dedicated to the region of the North and the Baltic Seas, she replaced mountain peasants by fishermen, who fight like the sand dunes with the stormy sea. In a comparison of land and people, wavy patterns of migrating dunes are parallelized with fishermen's forehead wrinkles. Their struggle with the open sea announces the Second World War, which is thereby elevated to a natural event like the tides. Two years later, the jurist and Nazi-sympathizer Carl Schmitt, in his writing Land and Sea (Land und Meer), defined a man as determined by land, although life came out of water and planet Earth consists to two-thirds of water:

Man is a landowner, a land recruiter. He stands and walks and moves on the firmly established earth. That is his point of view and his ground; this gives him his point of view; this determines his impressions and his way of seeing the world. He receives not only his vision but also the form of his walking and movement, his figure as a living being, born on earth and moving on the earth. (Schmitt [1942] 2018, 7) ${ }^{6}$

However, the space revolution (Raumrevolution), which started with overseas expeditions, attached great importance to the water as a field of domination and transformed peasants into pirates. Schmitt observes that a new space revolution is taking place through the conquest of the element of air, which suspends the old division between land and sea and makes them equal to the "nomos of the Earth"-the space of conquest, of division and of utilization (ibid., 71).

Franz Strunz (1875-1953), professor of history of natural sciences in Vienna and member of the NSDAP, even claimed that "landscape, especially the extreme landscape (not the easy comprehensible geometric one) forms the human. Man carries it with him, ill-humoured, when it is dark, plain and heavy, relieved and elevated, when he sees the

5 “Dunkle Harmonie im Moll wird gesprengt durch helles des nordischen Antlitzes, Gewalt der Gefühlshhythmen, unverbrauchte Naturkräfte bilden und formen das Gesicht des deutschen Ostens. Blutströme aller Stämme des Reiches brandeten im Wellenschlag der Jahrhunderte gegen die Fremdheit, die aus den östlichen Riesenräumen herandrängt. Gute, beste Volkskraft deutscher Lande suchte und fand Lebensraum im offenen Osten, gegen die aufgehende Sonne.“

6 “Der Mensch ist ein Landwesen, ein Landtreter. Er steht und geht und bewegt sich auf der fest gegründeten Erde. Das ist sein Standpunkt und sein Boden; dadurch erhält er seinen Blickpunkt; das bestimmt seine Eindrücke und seine Art, die Welt zu sehen. Nicht nur seinen Gesichtskreis, sondern auch die Form seines Gehens und seiner Bewegung, seine Gestalt erhält er als ein erdgeborenes und auf der Erde sich bewegendes Lebewesen." 
bright heaven over himself" (Strunz 1939, 144). ${ }^{7}$ He attributed to Germans a special relationship to nature und named German medieval mystics, romantic and symbolist poets, and writers as examples:

We Germans see the landscape as the most humane among all peoples of the earth. Landscape, folk character and homesickness are German destinies. We Germans have discovered it as a subjective experience: as a space experience and a mental-spiritual reproduction of this existence. Landscape is made up of landspace, spirit and sentiment. (Strunz 1939, 146)

According to Strunz, landscape has a power which can be compared to the transforming forces of historical events. At the same time, he declares homesickness to be a geo-psychical illness especially affecting the German nation (Volksgemeinschaft), understood as a community based on blood ties, due to its close relatedness to the soil and environment (Umwelt). This painful desire finally transgresses geography and becomes a form of biological self-preservation. Homeland therefore means, as Strunz concludes, "a paradigm of all reality and experience, just as man is the image of the world." ${ }^{9}$ Therefore, he declares homesickness closely related to wanderlust (Fernweh) and home as "a bridge to the world" (ibid., 151). Such understanding of home and homesickness has not excluded expansion. The conquest of new space for living was at the same time considered the natural right of a superior race: where it did not have it, it was doomed to conquer it-as "the nation without space" (Volk ohne Raum), propagated as a complementary ideology by the publicist Hans Grimm (1875-1959) in his eponymous book from 1926. The new territories in the East should provide space for future German generations longing for "freedom": in an eternal struggle for life, they had to extend their territory not only in a romantic-religious vertical direction to heaven, but also in a horizontal, expansive direction eastwards into the neighbouring, racially "inferior" countries (Grimm [1926] 1936, 9-11).

In the course of nineteenth- and twentieth-century nation building, the Janusfaced longing for the spirit of place was thus destined to become a central vehicle

7 “Landschaft und besonders die extreme Landschaft (nicht so sehr die geometrisch leicht fassbare) ändert den Menschen. Er trägt sie mit sich herum, verstimmt durch sie, wenn sie düster, niedrig und schwer ist, erleichtert und erhöht, wenn der Mensch den Himmel über sich erhellt sieht.“

8 “Wir Deutschen sehen die Landschaft am menschlichsten unter allen Völkern der Erde. Landschaft, Volkscharakter und Heimweh sind deutsche Schicksale. Als subjektives Ereignis haben wir Deutsche sie entdeckt: als Raum-Erlebnis und eine geistig-seelische Nacherzeugung dieses Daseins. Landschaft setzt sich zusammen aus Landraum, Geist und Gemüt.“

9 „Die Heimat wird zum Paradigma aller Wirklichkeit und Erlebnismöglichkeit, so wie der Mensch das Bild der ganzen Welt ist.“ 
for patriotic defence of the homeland, on the one hand, or a means for the expansive appropriation of new territories, underpinned by milieu and racial theories, on the other hand. The process of evoking the spirit of place went hand in hand with sacralisation of the homeland and its compatriots, and the demonization of all those excluded from the primordial bond of community and nature, considered to be "foreigners" or "homeless nomads" as Jews (Darré 1942, 5-6).

In the following, I want to outline the process of a growing spirit of place in two multi-religious, multi-ethnical regions in southeast Europe during the long period of nation building from the nineteenth century to the post-communist period after the Yugoslav disintegration wars in the 1990s: Kosovo and Bosnia. First, I would like to demonstrate the role of discursive practices for reviving and re-enacting historical events of (imaginary) national or even transnational importance at a specific locationin order to evoke the spirit of place and to sacralise the sacrifice of the nation. Further, I will analyse the role of art and architecture to resituate the traces of the past or even to transfer the spirit of place from one location to another for the period when the place was occupied by enemies and thus not accessible. Finally, I will suggest some reasons to explain why the Field of Blackbird was inscribed, with long-lasting effects, as a holy place into the collective memory of the Serbs, whereas in Bosnia, similar efforts at the foundation of a common Bosnian identity reminded unsuccessful.

\section{The Genius Loci on the Field of Blackbirds in Kosovo}

The battle on the Field of Blackbirds (Kosovo polje), in which the Serbian knights were defeated together with their Bosnian allies by the Ottoman army on 15 June (according to the Gregorian calendar) respectively 28 June (according to the Julian calendar) in 1389, became an increasingly important historical event during the middle of the nineteenth century, not only for Serbian but also for international European politics. The Serbian struggle for liberation, although less supported by the Europeans than the battles in Greece, and the "Turkish question," concerning the division of the Ottoman legacy among new national states, raised the issue of the forgotten medieval battle (Zirojević 1998; Sundhaussen 1999; 2000). It soon took on a fateful dimension for Western Christian civilization and was reinterpreted as a moral victory of the Serbs, who finally chose the heavenly instead of the earthly kingdom, European democracy instead of oriental despotism. The English consul general in Serbia, Andrew Archibald Paton (1811-1874), was the first to include the most important episodes from the legendary battle in his travelogue Servia, the youngest member of the European family (1845). Among the glorified historical events was the decision of the pious 
but militarily unsuccessful Prince or Knez Lazar for the kingdom of God by the heroic sacrifice of the knight in his service, Miloš Obilić, who rode alone into the enemy camp and stabbed to death the leader of the Ottoman army, Sultan Murad, ${ }^{10}$ and finally by the betrayal of Lazar's brother-in-law, Vuk Branković, who did not rush to aid in the decisive battle (Paton 1845, 219-228). These topics were celebrated during the Serbian struggle for liberation in the early nineteenth century in folk ballads accompanied by a traditional music instrument, gusle, and published by the Serbian philologist Vuk Stefanović Karadžić (1787-1864). As excerpts from them were soon translated into several European languages and discussed by Jacob Grimm, Goethe and the historian Leopold von Ranke, they became very well known all over Europe (Heimstedt-Vaid 2004; Zimmermann 2012). Paton, who was not able to travel to the Field of Blackbirds on Ottoman territory and therefore only visited the mummy of the prince kept at the monastery Vrdnik (resp. Nova Ravanica), on Fruška gora in North Serbia, perceived the medieval battle as the beginning of the continuing fight of the Serbs for their place in the European family of nations. In Russia, which legitimized its imperial claims on the Balkans with the protection of all Orthodox believers, there was no place for the Serbian national heroic myth. ${ }^{11}$ Instead, the Russian army was to be praised as the liberator of the southern Slavs (Zimmermann 2014c).

In the following decades, British writers, or those based in Great Britain, increasingly presented the mythical battle as a struggle of European significance. In travelogues from the end of the nineteenth century, when new nation states were founded after the Berlin Congress in 1878, the process of sacralisation of the Fields of Blackbirds in Kosovo intensified (Zimmermann 2014a, 305-314). Whereas early reports, published around the middle of the nineteenth century, described the landscape in a distant manner through the eyes of a historian and geographer, towards the end of the nineteenth century the events of the past became animated and re-enacted as a sacred theatre within their landscape. Nature took part in the fate of the nation. In her report Travels in the Slavonic Provinces of Turkey-in-Europe, written in 1867 and published together with the suffragist Paulina Irby (1831-1911), Georgina Muir

10 Paton calls him Amurath.

11 Reports from Slavonic Lands (1844-1847) was published by the Russian Slavicist Victor I. Grigorovich, who does not mention the famous battle at all (Grigorovich 1916). Slavicist and Russian consul in Sarajevo Alexander F. Gil'ferding (Hilferding) describes how the Field of Blackbirds became an important sacred place for the Serbian national identity in his Travel through Bosnia, Hercegovina and Old Serbia (1858), but perceives it only as an unfavorable territory for military confrontation (Kožančikov 1873, 167-198). He considers Knez Lazar's decision to confront the Ottomans on an open field strategically unwise and a tragic result of his bad military experience. For the Russian diplomat, the battle is less a heroic deed of the Serbs than a common effort of all South Slavs as well as Hungarians and Albanians to defy the Ottoman invasion. 
Mackenzie (1833-1874) empathetically describes the empty scenery of the great battle in which Eastern despotism conquered European civilisation. Regretting that no traces remained from the times when Serbia still belonged to Europe, she compensates for the loss by insightfully reviving the plain field in the detailed weather description that evokes the tragic-melancholic spirit of this place:

The morning, on which we entered Kóssovo was chequered by those alternations of cloud and gleam which usually herald a showery day. The wind blew fresh from the snow-wreaths on Liubatern, and swung aloft the boughs of the oak-copse, showing bright little lawns and dewy pastures, to which the grazing horses and cattle pushed their way through brushwood and fern: we felt that we had exchanged the yellow plains of the East for the green mountains and watered valleys of Europe. Unhappily, the verdure and the breeze are all that now testify of Europe on the field of Kóssovo. Old chronicles tell that at the time when a Turkish army first appeared on it the country was well cultivated and peopled with villages....Yeas, in those days Kóssovo belonged to Europe-to a society, though rude, of activity and progress; but it was conquered to be a pasture-ground for Turkish horses, on just such a showery morning as this, some five hundred years ago. (Mackenzie and Irby 1877, 182-183)

However, the local Serbs would compensate for the lack of historical traces by reciting folk ballads and by vivid, colourful descriptions of the battle-as if they had themselves participated in it.

....and so fresh remains its memory that to this day it is scarcely possible for a traveller to converse from more than a few minutes with a genuine Serbian without hearing the name of Kóssovo....As for any one who has been much in Serbia, and has studied the national traditions and songs, he will at last come to feel almost as if he had been at the battle of Kóssovo himself, so minutely is every detail enumerated, so vividly are the motives and actions realised, so deep the lines, so strong the colours, in which the principal characters are drawn. (ibid., 183-184)

The writer and artist Mary Edith Durham (1863-1944) reports in her travel journey Through the Land of Serbs, published in 1904, how strongly the memory of the past dominates present life: "They sang me snatches of Servian ballads-all monotonous wails over the slaying of someone by the Turks, ending in a cry for vengeance" (1904, 202). A year later, in the travel report The Burden of the Balkans (1905), the author warns in the preface that the contemporary revolts in the Balkans are no longer only 
of religious origin, but have racial motives, asserting that the revolutionary party in Bulgaria would also murder Christians of all other Balkan nations when the opportunity occurred (1905, vii, viii). She describes the Balkan people as living "in their past to an extent which is hard for us in the West to realize" (ibid., 4). In her 1909 report High Albania, which includes Kosovo, she realises that the region was populated at that time mainly by Albanian-speaking people $(1909,278)$. Nevertheless, the Serbian population used to regard the region as its own and to appropriate it by comparing the historical battle with catastrophes of biblical proportions and by interpreting natural phenomena as divine miracles:

There spread out, burnt, and parched before us for miles and miles, was Kosovopolje, the fatal field on which the Turks gained the victory that established them, even to this day, in Europe-the Armageddon of the Servian people. "Kosovopolje", said the Serb briefly. It summed up all the fate of his race. In the spring every year, he added, all the unploughed land is covered with blood-red flowers that grow in memory of the fight; they are sent by God. We struck across the great plain, uncultivated, desolate, and undulating; the parched turf was slit into yawning cracks by the drought, the scrub hawthorn burnt brown, the track dusty, and we reached the Sirnitza, crawling shrivelled between banks of cracked mud-the river that once ran red with the blood of heroes. (ibid., 278-279)

A few years later, in the course of the Balkan wars (1912-1913), the Kingdom of Serbia conquered the Ottoman territory of Kosovo, only to lose it a few years later, when the Serbian army led by King Peter I had to escape into exile on the island Corfu in 1915. During the First World War, the Kosovo myth was again popularised not only by Serbs but also by the British and Scots. It was used not only as a propaganda means for the fight of the British allies against Germany and Austria-Hungary, but also for the foundation of a future common south Slavic state under Serbian supremacy on the territory of the dissolved Habsburg and Ottoman Empires. In London, a "Kosovo Day Committee" was founded by several prominent intellectuals and artists who supported the foundation of a pan-Slavic state, among them the historian Robert William SetonWatson (1879-1951), the archaeologist Arthur Evans, the French sculptor Auguste Rodin, the American painter John Singer Sargent, the Belgian poet Emile Verhaeren and other representatives of society (Zimmermann 2014a, 314-330; 2014c). Seton-Watson, who held a leading position in the committee, and Sir Cecil Smith (1859-1944), director of the Victoria \& Albert Museums, enabled the Serbs to celebrate the anniversary of the battle in exile in London, accompanied by a large exhibition of heroic sculptures and a model of a future Kosovo temple, which was to be erected on the Field of 
Blackbirds after the foundation of the new multi-national South Slavic state (Interview memorandum from 29 May 1915, Archive of the Victoria \& Albert Museum, Blythe House). Monumental, temple-like architecture and memorial sculptures in antiquated forms with caryatids, muscled fighters, mourning women and a sphinx, by the panSlavic Croatian sculptor Ivan Meštrović (1883-1962), were arranged as a sacred place (Wachtel 1998, 63ss; Clegg 2002; Zimmermann 2014a, 314-326; 2014b; 2014c; see Fig. 1 and 2). The ensemble, reminiscent of an antique temple, was probably inspired by the myth about the antique origin of the Slavs, which had been spread some decades earlier already by the pan-Slavic linguists Cyprien Robert (1807-ca. 1865) at the Collège de France in Paris as well as Ján Kollár (1793-1852) and Martin Žunkovič (1858-1940) in the Habsburg monarchy (Zimmermann 2016a; 2016b). On the basis of topographical names, they tried to derive the mythical origin of the Slavs from several old cultures, such as Old Macedonians (also identified as Illyrians) and Etruscans. By presenting the South Slavs as heirs of ancient cultures, they raised a claim of a close attachment with the spirit of a place, which was ultimately also important for the foundation of European culture. Meštrović, who also tried to omit the style of conflicting national religious traditions-the warriors do not wear medieval suites of armours or any kind of clothing, thereby imitating antique heroes-created a common temple capable of celebrating the unity of all South Slavs. As the place was not accessible, he anticipated the erection of a pan-Slavistic temple in London. The detachment from the sacred soil was outbalanced by the monumentality of the art work, which established a sacred environment. It was clear that it would have a convincing place on the Kosovo field, which Great Britain and its allies were about to re-conquer.
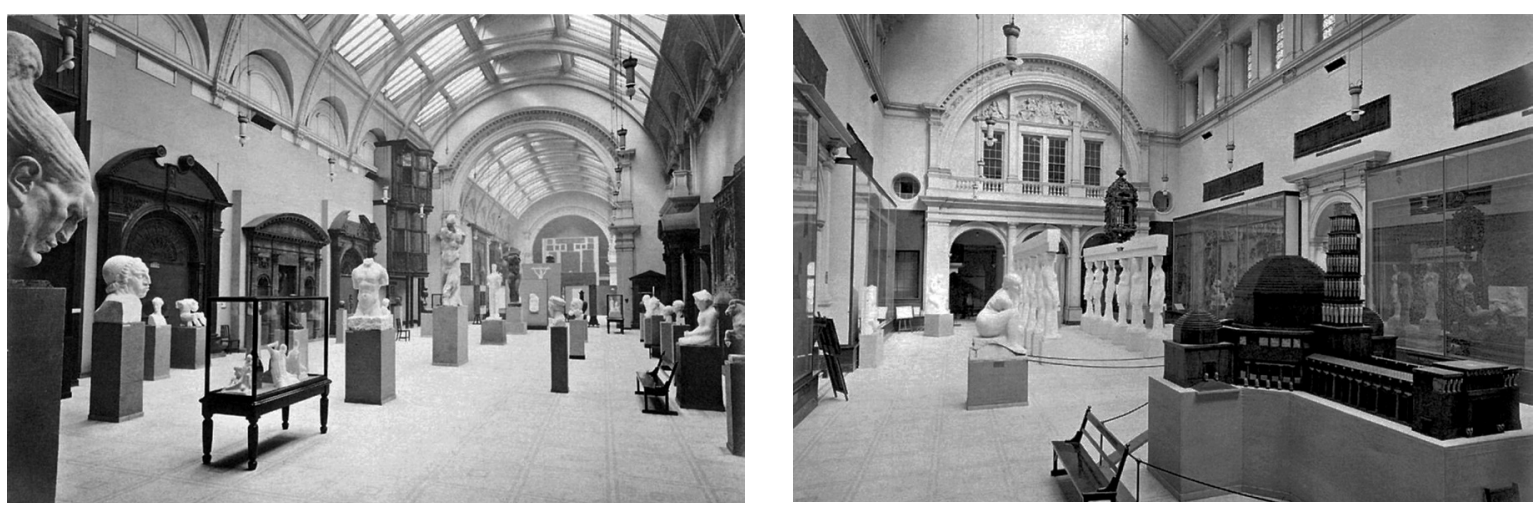

FIGURE 1+2 Meštrović exhibition at the Victoria \& Albert Museum, London, 1915, from: Clegg, Elisbeth. 2002. "Meštrović, England and the Great War." The Burlington Magazine 144 (2002), 740, Fig. 29, 30. 
In his contribution to the exhibition catalogue, James Bone (1872-1962) describes the suggestive effect of the temple construction with its monumental, expressive sculptures:

You entered a loggia formed of mourning caryatids, down which a sphinx, human save in the wings, stared watchfully and expectantly. Looking between the figures of the loggia, you saw groups of widows whose mourning and hopelessness were expressed in gestures with a primitive directness and force that came as a shock to the visitors. The loggia led to a small doomed hall, in which was a gigantic statue of the hero Marko Kraljević, the Serbian Siegfried, on his snorting horse. Round the walls in tall panels were torsos of Turks, and above was a rhythmic frieze of mingled figures of Serbs and Turks fighting. On either side of the hall were arched gateways and inside the arches were grotesque heads of Turks set in panels, two deep all the way round. You descended steps supported by crouching figures that symbolized the Serbs in captivity_-gaunt, worn men with beards, their hands, palm downward, extended flat, a sign of subjection and insufferable strain. There was an extraordinary fury and purpose in every part of this strange building that moved one like the sight of blood or the call of trumpets. It was described as 'fragments of the Temple of Kosovo', the name of the fatal field where the Serbian nation went down, to remain in subjection for five hundred years.... It had a burning spirit within it that seem to throb gesture through these forms as a tempest speaks through the new and fantastic shapes it gives to the trees in its grasp, or the announcements of the tongues and crowns of flame in a forest conflagration....Its beauty comes like the beauty of the flames, which is fire itself. (Bone 1915, unpaginated)

The artist received inspiration from "vivid folk-songs of his country, and something of the starkness and grandeur and terrible silhouettes of the wild hills seems to remain in his work," argues Bone. Such an expressive sort of art, bearing the militant past of the Balkan landscape in it, could be understood in times of war by British citizens as well:

“In ordinary times the art of Meštrović might be too alien to England with our tradition of decorum and comfort, but in these times of stress the mood has been impelled upon us through which we can see and feel the message of his terrible images and the deep pitifulness, too, that lies within them. His heroic art, indeed, is almost the only art that does not seem alien to these mighty days." (Bone 1915, unpaginated) 
The exhibition was accompanied by numerous meetings, lectures and propaganda booklets (Zimmmermann 2014a, 326-330). At the same time, on 15 October 1915, the Czech philosopher and later president of the pan-Slavic state Czechoslovakia, Tomáš Garrigue Masaryk (1850-1937), who emigrated to Great Britain and became a professor of Slavonic Studies at King's College in London, held his inaugural lecture on small, stateless nations at the very moment when Serbia was about to be attacked by Germany, Austria-Hungary and Bulgaria. He emphasised the importance of heroism and cultural heritage for the survival of small nations and gave the living memory of the Field of Blackbirds in Kosovo, sung in Serbian ballades, as an example. A befriended Serbian lieutenant had told him about it:

When at the head of his regiment of peasant soldiers he reached the plain of Kosovo, the famous 'Field of Blackbirds', a death-like silence seized the whole detachment; men and officers, without any command, uncovered their heads, crossed themselves, and each of them tried to thread softly, so as not to disturb the eternal sleep of their heroic ancestors. (Here, my friend, quite lost in the remembrance of that great experience, unconsciously imitated their gait, and his voice fell to a whisper as he recalled the silence of his soldiers.) Many of the weather-beaten faces were bedewed with unconscious tears, as was my friend's face while he spoke. I, too, was deeply affected by the recital of his experience. (Masaryk [1917?], 21)

The simple Serbian peasant soldiers, impressed by the imaginary spirit of place, moved on the battlefield as if participating in a sacred ritual or playing in a sacral theatre. The location inhabited by the spirit of place has an impact on the performance of its visitors.

For the anniversary of the battle in 1916-1917, 85,000 copies of the booklet The Lay of Kossovo: Serbia's past and present were published. The authors, among them the British writers Alice (1874-1917) and Claude (1865-1917) Askew, even tried to conjure up the medieval dead warrior in their appeal. A cult of the dead was supposed to capture the spirit of place:

If only the dead could rise! Ah, if only our dead heroes could rise from their graves on this plain and lead back into battle! Lazar, Milosh Obilitch, Kosanchich Ivan, why do you slumber? Is Serbia to be lost a second time?... Hail to Kossovo Day, for it will be followed by the day of victory! (Askew 1917, 31)

Although five hundred years had passed since the battle, the medieval warriors were revived and their presence was invoked for revenge. The publicist Gilbert Keith 
Chesterton (1874-1936) compares them with the "living dead", who enjoy eternal life in the memory and identity of the nation:

Five hundred years ago our Allies the Serbians went down in the great Battle of Kossovo, which was the end of their triumph and the beginning of their glory. For if the Serbian Empire was mortally wounded, the Serbian nation had a chance to prove itself immortal; since it is only in death that we can discover immortality. So awfully alive is that Christian thing called a nation that its death is a living death. It is a living death which lasts a hundred years longer than any life of man. (Chesterton 1917, 31)

At the same time, Chesterton legitimates Serbian claims to Kosovo, as if the death of Serbia's ancestors on the Field of Blackbirds-like the death of Christian martyrs-had transfigured the territory into a holy place, almost sacramental, consecrated by the blood that was shed on it. Pointing to the close relationship between Christian culture and its holy places, he declares it a sedentary one and contrasts it with the nomadic, Islamic mentality formed in the desert and therefore lacking any relation to a placeand also any legitimacy to claim it:

And the chief fruit of this philosophy is the national idea itself, the sacramental sense of boundary, the basis, in an almost religious sense, of agriculture, the idea of having a home upon this earth, which the Arab armies out of the deserts can hardly even be said to have violated, having never even begun to understand. (ibid., 34)

Chesterton thus denies Muslims-supposedly nomads by nature-any claim to the spirit of place and any possibility of marking a place or being primordially linked with it; with their blood bond, the Serbs had laid the boundary of the Christian frontier and became the preservers of the holy place.

Due to the foreseeable expenses and the dominant role of the Serbs in the myth, Mestrović's temple was never realised. Instead of the Kosovo temple, the sculptor built a monumental tomb of the Unknown Soldier in Avala, near Belgrade, decorated with the titanic women personifications of various Yugoslav regions, significantly not of the ethnic nations. Only the destroyed church of St. John the Baptist, in Samodreža on the Kosovo field, which was believed to be the sacred place where medieval warriors had attended divine service and obtained sacrament for the last time before going to battle $e^{12}$, was rebuilt in 1932 by the architects Petar Popović (1873-1945) and

12 The Russian consul in Sarajevo, Alexander Gil'ferding, reports in his travelogue that he was not able to visit the ruins of the church Samodreža because nobody informed him about such a place 
Aleksandar Deroko (1894-1988) (Cultural Monuments in Serbia 2018). Only in 1953, in the communist period, a non-religious memory tower was erected, designed by sculptor Aleksandar Deroko, at the memorial place Gazimestan (Ubiparip 2017, 251). The Kosovo battle, together with the peasant uprisings in the sixteenth century, was interpreted at that time as the anticipation of the partisan struggle against fascism (Zimmermann 2010a). In 1989, when the $600^{\text {th }}$ anniversary of the battle was celebrated under Slobodan Milošević's rule (1987-2000), religious rituals were reanimated in the Serbian nationalist context (Zimmermann 2014a, 330-355; 2014b; 2014d). The images of sacred warriors were resurrected in ethno pop songs, in radio re-enactments of the battle, on the front pages of the press, in radio and film. The remains of the fallen prince Lazar, which rested in the monastery Vrdnik resp. Nova Ravanica for centuries, were brought to the Kosovo field for the festivities (Perica 2002, 128). The religious national myth appropriated the genius loci, evoking its spirits in modern media and mobilizing it for the new war, which ended with its loss, depicted as yet another martyrdom of orthodox religion.

Today, the spirit of place on the Field of Blackbirds again attracts foreign travellers. In 2016, an anonymous British tourist confessed in the Bohemian Blog, an alternative online travel journal, that he or she visited the Field of Blackbirds due to its war-time past:

It was war that attracted me to Kosovo. I don't like writing that, but it's the truth.... Back then though, all I knew about the place was the Kosovo War. I remember a year when it seemed to be all that was ever on the news; when I was growing up, Yugoslavia was never far from the headlines and by the time I was old enough to start paying attention, suddenly it wasn't there anymore. Watching a country disappear from maps like that changed my understanding of the world. Borders weren't static, just because they were printed in books. I realised history was still alive, and later, in 2008, Kosovo was the first time I followed the birth of a new nation.... may be no stranger to 'dark tourism,' but somehow this felt more provocative than any place I'd been before; it wasn't like Auschwitz or Chernobyl, with their guided tours and guest books. There was no tourist trail connecting the Kosovo massacre sites, no English signposts to the places where bloody war had raged only 15 years before. Exploring Kosovo, it felt like the dust had barely had

during his sojourn in Kosovo. He was only able to visit the tomb of the fallen Ottoman Sultan Murad I., with a cenotaph in Arabic supposedly erected by his follower Bayezid I, where the inner organs of the sultan were buried (Kožančikov 1783, 200). In their travelogue The Stricken Land $(1916,58)$, Alice and Claude Askew do not name Samodreža as the place where the Serbian soldiers obtained the sacrament, but rather the monastery church of Gračanica. 
time to settle and at times, I would find myself wondering How soon is too soon? (Bohemian Blog 2016)

Although Kosovo has not been a part of Serbia since 2008, but belongs to the autonomous Republic of Kosovo, the spirit of place on the Field of Blackbirds is still alive. The latest war, of 1999, called it to mind and transformed it into a location for 'dark tourism'. The Serbian memorial at Gazimestan is fenced and monitored by cameras to prevent it from being destroyed by Albanians:

Arriving at the gates by taxi, a lone guard came out to meet me. It felt very much as though I were crossing a border; showing my passport before being ushered through a security gate into the political limbo beyond. I was alone at the monument that day. Alone, that is, save for the scattering of CCTV cameras that watched my every step on the windy hillside. (Bohemian Blog 2016)

Gazimestan, the memorial place in the heart of the Field of Blackbirds, where the heroes of the medieval battle are supposed to have died, became a place difficult to access. It is protected like holy places, where non-believers or believers of other religions are allowed to approach only for a short time and under surveillance.

\section{Absence of the Spirit of Place in Bosnia}

A different pattern of appropriating the spirit of place occurred in Bosnia, which became a protectorate of the Habsburg monarchy in 1878. As early as the 1870s, the Ottoman Empire, while attempting to reform its administrative structures, permitted the previously prohibited construction of sacred places of non-Muslim religions (Sundhaussen 2014, 136). Amid the spread of national ideas, religious communities increasingly felt united by ethnic collectives. After the withdrawal of the Ottoman administration and of a part of the Muslim population from Bosnia, newcomers from the Habsburg Empire and the Principality of Serbia started to settle there: Serbs, Croats and Ashkenazy Jews (Sephardic Jews from Spain had migrated to Bosnia during the Reconquista in the fifteenth and sixteenth centuries already [ibid., 81-85, 192-197]). In 1882, the Austro-Hungarian politician and historian Benjamin Kállay (1839-1903), who had been appointed first consul-general in Serbia from 1868 to 1875, became governor and started to modernise the province according to Western models (MilojkovićDjurić 2000; Okey 2007, 55-144; Sundhaussen 2014, 205-213). His aim was to awaken a common Bosnian national sentiment in order to prevent the spread of diverging 
nationalisms and to remove the Orthodox population from Serbian and Russian influence. In his book Russia's Oriental Politics, written in 1878, he already expressed his concern about Russia's new strategy to reinforce its influence in the Balkans by means of pan-Slavic propaganda (Kalaj 1885, 101-103). While the Russian empire protected all the Orthodox nations-the Greeks, the Romanians and various Slavic nations - at the beginning of the nineteenth century, it started to support particularly the Slavic "brothers" amongst Orthodox believers around the middle of the nineteenth century (Zimmermann 2014a, 103-107). Together with the enlightened local Bosnian authorities, particularly the major of Sarajevo Mehmed beg-Kapetanović (1839-1902) (Lindemann 2015, 64-68), Kállay therefore tried to diminish religious bonds and to intensify the ties to the region of Bosnia without, however, recurring to mythopoetic strategies of evoking the spirit of place. Unlike in Kosovo, this process coincided with a form of sacralisation of the entire territory. For this purpose, a common ancestor of all Bosnian religious communities was found: the Manichaean heresy of the Bogumils, which, at the end of the tenth century, had spread from Bulgaria to the Bosnian territory and became a dominant religion. Croatian professor of theology, historian and first president of the South Slavic Academy of Sciences and Arts Franjo Rački (1828-1894), in his book The Bogumils and the Patarens, published in 1870, convincingly interpreted the rapid conversion of a broader population to the Muslim religion, after the conquest by the Ottomans in 1463, as resulting from the pre-existing heretic religious inclinations persecuted by the Eastern as well as by the Western Church (Zimmermann 2014a, 240). Under Kállay, this view was turned from a negative historical identity based on religious demarcation into a positive myth. The Hungarian writer Johann (János) von Asbóth (1845-1911), who for several years accompanied Kállay on his travels through Bosnia and Hercegovina, published a travelogue in 1888. He presents the Bogumils as the melting and uniting power of Bosnian history (1888, 27-35). As the third component between East and West, the sect represents the central "principle of Bosnian history" (ibid., 28). He starts by referring to one of the rare monumental reminders of Bogumil culture:

They are called the Bogumil tombs. And that those in fact belonged to some specific sect can be hardly doubted, as it can be observed that the tomb monuments are ornate neither with a cross nor with a turban; they also show no symbols of any other contemporary existing confession, whose adherents in this country, where religious life is deeply rooted, would certainly have never forgotten the signs of piety. (...) Who and what were these Bogumils? Interesting question. It will be demonstrated that the Bogumilian principle is, so to speak, the principle of Bosnian history. This is the axis around which everything revolves, so much that everything 
that is not related to it is limited to simple rivalries for personal power. This goes so far as to say that we can raise the question whether the Bogumils founded as well as ruined the Bosnian state. The question is important, important for Bosnia, since the Bogumils actually quite rightly called their religion the Bosnian, important in relation to the Hungarian empire, since the Bogumilian period coincided with the era of Hungarian supremacy and the sect played a major role in all Bosnian undertakings of the Arpads, Anjous and Hunyadys. Finally, the Catholic Church and Hungary lost Bosnia because they were not prepared to tolerate the Bogumils. But the question is also important from a wider European point of view. (...) It is certain, however, that especially Manichaeanism and the Bogumils belonged to the first sects who arose in the first centuries of Christianity; there is also an organic connection between them and the Western European Reformation. It is undoubted that Bosnian Bogumilism has given a powerful stimulus to the Western European Reformation. Although not identical with it, it was in a sense the father of the same. (ibid., 27-28) ${ }^{13}$

Asbóth subscribes to Rački's theory that the Bogumils later converted to Islam, which advanced Bosnian Muslims, in the eyes of the Austro-Hungarian occupant, from residual residents of the Ottoman period to the status of forming the core of the Bosnian nation:

13 "Man nennt sie Bogumilen-Gräber. Und das dieselben in der That irgend einer besonderen Secte sind, läßt sich kaum bezweifeln, wenn man wahrnimmt, das die Grabmonumente im Allgemeinen weder ein Kreuz, noch einen Turban zeigen, also keinerlei Symbol der gegenwärtigen bestehenden Konfessionen, deren Anhänger in diesem Lande, wo das religiöse Leben jeder Zeit ein tiefgewurzeltes war, jene Zeichen der Pietät gewiß nicht vergessen hätten. (...) Wer und was waren diese Bogumilen? Eine interessante Frage. Denn es wird sich zeigen, daß das bogumilische Princip sozusagen das Princip der bosnischen Geschichte ist. Das ist die Achse, um die sich alles dreht, so sehr, das Alles, was nicht mir ihr zusammenhängt, sich auf einfache Rivalitäten um die persönliche macht beschränkt. Es geht dies so weit, das man fragen darf, die Bogumilen gründen den bosnischen Staat und durch sie geht es zu Grunde. Die Frage ist wichtig, hochwichtig bezüglich Bosniens, da die Bogumilen ihre Religion thatsächlich mit Fug und Recht die bosnische nannten, hochwichtig in Bezug auf das ungarische Reich, da das bogumilische Zeitalter mit der Ära der ungarischen Oberherrschaft zusammenfällt und die Secte in allen bosnischen Unternehmungen der Apaden, Anjous und Hunyadys eine Hauptrolle spielt. Schließlich verlieren die katholische Kirche und Ungarn Bosnien, weil sie die Bogumilen nicht dulden wollen." Die Frage ist aber auch vom weiteren europäischen Gesichtspunkte wichtig. (...) Gewiß ist jedoch, daß ebenso wie zwischen den ersten Secten und namentlich dem in den ersten Jahrhunderten des Christenthums entstandenen Manichäismus und den Bogumilen, auch zwischen diesen und der westeuropäischen Reformation ein organischer Zusammenhang besteht, und es ist zweifellos, daß der bosnische Bogumilismus eine mächtige Anregung zur westeuropäischen Reformation gegeben hat. Wenn auch nicht identisch mit ihr, war er doch in gewissem Sinne der Vater derselben." 
There can be no doubt that the Bogumilians initially converted massively to Islam, while the rest later gradually seemed to follow. A great part did this, especially at the beginning, certainly with the reservation of returning to the old faith in a favourable moment. Always persecuted, they may have learned to deny their beliefs for a time. But since the favourable moment did not come, this intention had to be gradually and completely forgotten by the later descendants. (ibid., 90) ${ }^{14}$

The Bogumils were now praised as having founded a pre-Ottoman, trans-religious common identity, thereby unifying various ethnic groups. The new common Bosnian identity, Bošnjaštvo, invoking an old, extinct religion that had not left any living cult practices, was supposed to be able to bridge ethnic and religious differences once again. Whereas the Kosovo myth was directed against the Muslim religion and never tried to integrate the Albanian population, the myth of the Bogumils was, on the contrary, destined not only to integrate them but to attribute to them the leading role in the process of the new Bosnian nation building.

The collection of the National Museum (Landesmuseum resp. Zemaljski muzej) in Sarajevo, founded in 1888 and destined to contribute to the formation of a common Bosnian identity, was focused on the pre-Ottoman history of medieval Bosnia (Bagarić 2008). In 1913, a monumental new edifice in a neo-renaissance style was built by a Viennese architect of Czech origin, Karl Pařik (1857-1942), a pupil of Theophil von Hansen (1813-1891). In the garden, a large collection of Bogumilian grave steles (stećci), brought from different scattered places in Bosnia, was displayed (see Fig. 3). Rather than a sacred place, the museum, as an enlightened scientific institution preserving and studying the traces of the past, was supposed to become an institutional centre of a nation deprived of ethnic affiliations and religious conflicts.

Kállay's concept of uniting all Bosnians was deemed to fail. In the all-too-enlightened museum, the secularisation of religion went along with the alienation from the spirit of place. The Habsburg authorities and their local supporters upheld the Bogumilian myth in order to introduce a model of historical identity allowing for an equal participation of all ethnic groups in Bosnia. However, none of them engaged in the revival of the myth with energy comparable to that of the Serbs projecting their national mission onto the Field of Blackbirds. The Austro-Hungarian administration failed when it proposed an

14 „Es kann kein Zweifel darüber bestehen, dass die Bogumilen gleich anfänglich in Massen zum Islam übertraten, während der Rest später allmählich nachgefolgt zu sein scheint. Ein großer Teil that dies, namentlich in der ersten Zeit, gewiß mit dem Vorbehalte, in einem günstigen Augenblicke wieder zum alten Glauben zurückzukehren. Stets verfolgt, mochten sie wohl gelernt haben, ihren Glauben zeitweilig zu verleugnen. Nachdem aber der günstige Zeitpunkt nicht kommen wollte, mußte diese Absicht allmälig und bei den späteren Nachkommen umsomehr ganz und gar in Vergessenheit geraten.“ 
imaginary common history to the Bosnians of different ethnic groups and religions they governed.

Several large exhibitions accompanying the enlightened Austro-Hungarian project did not provide sacred environments that mythically evoked the spirit of a multinational place, but rather invited people to cosy, profane buildings. The so-called "Bosnian House" at the Millennium Exhibition in Budapest in 1886, another house at the Emperor's jubilee exposition in Vienna in 1898 and the Bosnian-Herzegovinian pavilion erected in the Rue des Nations for the Paris World's Fair in 1900 were hybrids of a Bosnian architecture and invented pseudo-Moorish stylistic elements (Reynolds 2014, 106-108; Hajdarpasic 2015, 192-196; see Fig. 3). They were all designed by foreign architects and engineers-for instance, the Bosnian-Herzegovinian pavilion in Paris by the Czech artist-architect Carl Panek and the painter of advertising posters Alfons Mucha (1860-1939), who transformed Bosnian oriental style into fashionable orientalism of Art Nouveau, adapted to the European taste (see Fig. 4).

The spirit of place was substituted with a commercialised orientalist environment, adapted to European spectators. The exhibition, resembling ethnographic shows, presented Bosnia as a symbiosis of exotic costumes and traditional way of life, on the one hand, and modernist achievements of the "wise empire" in education, in the construction of factories, mining, road and rail network, in agriculture and forestry, in the press and culture, on the other hand.

Already the exterior of the pavilion, above all the defiantly towering tower, is reminiscent of the struggles from which the double province came to the blessings of peace, and the oriental façades with their wooden architecture and the women's oriel point to the time when Bosnia was ruled by the Half Moon. On the other hand, in the interior of the building visitors encounter Austro-Hungarian Bosnia. The entrance hall, a lounge coquettishly decorated with Bosnian oriental carpets, makes a friendly, comfortable impression. On the right, we find a Bosnian-Mohammedan women's chamber with its beautiful inhabitants, a view to an impressing panorama of the city of Sarajevo with its mosques, its fountain and the large bazaar by the painter Adolf Kaufmann. Continuing on the right, a hall equipped with mythical pictures from Bosnian history by Alfons Mucha opens up, in which there are also two interesting equestrian models ('Bosnian Boys'). While the ground floor gives a picture of the Bosnian artistic life, the country products, artisan products and outstanding buildings, especially educational institutions, are presented to us in models and prospects on an upstage. (Fromm 1900, 448) ${ }^{15}$

15 "Schon das Aeussere des Pavillons, vor allem der trotzig emporragende Turm, gemahnt an die Kämpfe, aus denen heraus die Doppelprovinz zu den Segnungen des Friedens gelangte, 
After numerous orientalist travel reports that had been published since the occupation of Bosnia in the annexation year 1908, the first travel guide with practical tourist information about the duration of trips, quality of hotels, shops selling souvenirs and prizes, The Bosnian Eastern Railway (Die bosnische Ostbahn), appeared. It was written by
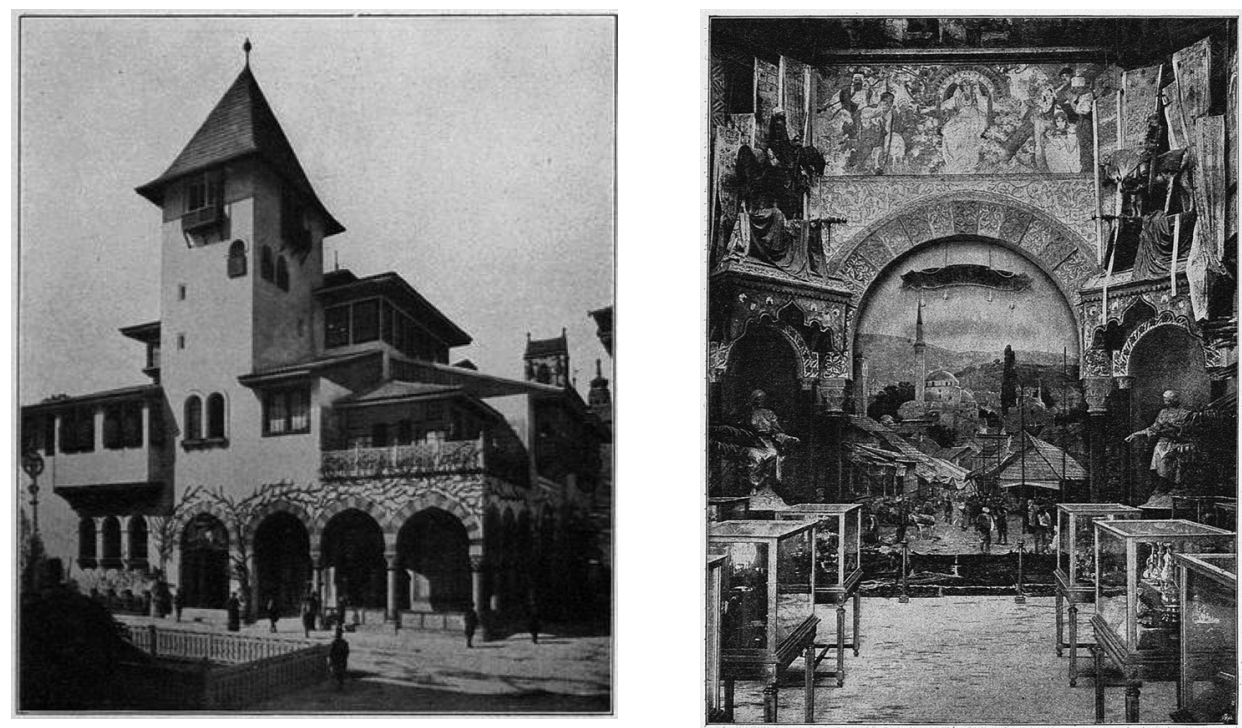

FIGURE 3 (left) Bosnian-Herzegovinian pavilion, World's Fair in Paris, 1900, exterior, from: Die Weltausstellung in Paris, edited by A. J. MeierGraefe. Paris: F. Krüger 1900, 30.

FIGURE 4 (right) Bosnian-Herzegovinian pavilion, World's Fair in Paris, 1900, interior, from: Fromm, Carl Jos. 1900. "Bosnien und die Hercegowina auf der Pariser Weltausstellung." In Die Pariser Weltausstellung in Wort und Bild, edited by Georg Malkowsky, Berlin: Verlag Kirhhoff \& Co. $1900,450$.

und die orientalischen Fassaden mit ihrer Holzarchitektur und den Frauenerkern weisen auf die Zeit hin, in der Bosnien noch unter dem Halbmond stand. Dagegen tritt dem Besucher aus dem Inneren des Gebäudes das österreichisch-ungarische Bosnien entgegen. Der Vorraum, ein mit bosnisch-orientalischen Teppichen kokett ausgestattete Salon, macht einen freundlichen, behaglichen Eindruck. Wir finden da rechts ein bosnisch-mohammedanisches Frauengemach samt seinen schönen Bewohnerinnen, im Prospekte ein von dem Maler Adolf Kaufmann herrührendes gelungenes Panorama der Stadt Sarajevo mit ihren Moscheen, ihren Brunnen und dem grossen Bazar. Weitergehend eröffnet sich uns rechts eine mit Muchaschen Bildern aus der bosnischen Geschichte ausgestattete Halle, in der sich auch zwei interessante Reitermodelle (, bosnische Boys') befinden. Während so das Erdgeschoss ein Bild des bosnischen Kunstlebens giebt [sic], werden uns auf einer Emporbühne die Landesprodukte, kunstgewerbliche Erzeugnisse und in Modellen und Ansichten auch hervorragende Bauten, besonders Unterrichtsanstalten, Bosniens vorgeführt." 
Vienna-born writer and journalist of Croatian origin, Milena von Preindlsberger-Mrazović (1863-1927), an influential mediator between cultures. The guide, which also provides information on the "Bosnian-Herzegovinian Tourist Club", founded in 1892, as well as other publications of this kind testify that Bosnia-Herzegovina became a popular tourist destination in Austria-Hungary at the time. The spirit of place became a part of a tourist offer, of a landscape with standardised routes and sights for experiencing a European Orient.

In socialist Yugoslavia, after the break with the Soviet Union in 1948, the Bogumilian myth was again used, this time in order to propagate Tito's "third way" between East and West (Zimmermann 2010a; 2010b; 2014a, 232-246). The heresy based on the double refusal of Western and Eastern Orthodoxies was perceived as the anticipation of a specific form of Yugoslav socialism, resembling neither Soviet communism nor Western capitalism. Its leader, President Tito (1892-1980), was compared with the founder of the sect, Bogumil. The most important propagators of the communist Bogumilian myth were the Croatian writer Miroslav Krleža (1893-1981) and the Serbian art historian Oto Bihalji-Merin (1904-1993). As was the case with the period of Kállay's leadership as Austro-Hungarian governor in Bosnia, the myth was again imposed from the outside. In 1950, Krleža organized an exhibition of Yugoslav medieval art in the Palais de Chaillot in Paris, transforming a huge hall into a temple where various religious ancestors were brought up as historical anticipations of the "third path": along with the Bogumils, visitors were introduced to the Serbian autocephalic church and the Glagolith writing and culture in Dalmatia following the spread of Slav liturgy in the ninth century by the apostles Cyril and Methodius. The religious message of the monuments was neutralised by interpreting them as manifestations of folk culture anticipating a common Yugoslav history. One of the famous partisan films nominated for an Oscar, Battle on Neretva (1969), in which international stars, together with Yugoslav actors, played heroes of the partisan resistance against fascism, established a connection between Tito's partisans and the Bogumilian sect. In the film, the partisans, who unified various South Slavic nations, heroically fight until the end behind the Bogumilian grave steles in the Bosnian mountains.

After the Yugoslav dissolution wars in the 1990s, some Bosnian intellectuals tried to use the remembrance of the Bogumils to create a new variant of Bosnian identity, now excluding the Serbs and the Croats and comparing, instead, the extinction of the Bogumils in the fifteenth century with the contemporary genocide (Lovrenović 2008). 


\section{Conclusion}

Kosovo and Bosnia are the scenarios of two different patterns of appropriating the spirit of place, but not equally successfully. In the former, the spirit of place was evoked over decades through intense discursive practices. It drew from monumental art and media, using them in an analogous manner to religious rituals in order to stage the events of the past as a sacred theatre. The spirit of place of the latter was based on rational, enlightened adaptations of history as displayed in museums or in commercialised ethnographic exhibitions, adapted to the taste of European spectators and designed by leaders coming from areas outside of the region. Kosovo polje was established as a national sacred place, whereas Bosnia, as a multi-ethnic territory, was promoted as a trans-religious or secular space, uniting different ethnicities and religions by way of the Bogumil identity-without, however, constituting a living religious cult. They both demonstrate how pathetic religious concepts of a holy place, based on the idea of the spirit of place, were recoded-in order to animate and legitimate the establishment of modern nations. Secularised, intellectual attempts at constructing a common memorial culture and myths of a common spirit of place uniting different ethnic and religious groups seem to be much weaker than emotionally charged myths claiming the exclusive right of one nation to inscribe itself into a given place and to forge a bond with the territory. The appropriation of a geographic area in the name of a sacred national history could succeed only if the spirit of place was kept alive within what a nation believed to be its identity and its mission.

\section{Reference List}

Asbóth, Johann von. 1888. Bosnien und die Herzegowina: Reisebilder und Studien [Bosnia and Hercegovina: Travel Pictures and Studies]. Wien: Alfred Hölder.

Askew, Alice, and Claude. 1916. The Stricken Land: Serbia as We Saw it. London: Eveleigh Nash Company.

- - . 1917. "Kossovo Day Heroes whose memory will never fade." In The Lay of Kossovo: Serbia's Past and Present (1389-1917): For the Anniversary of the Kossovo Day Celebration in Great Britain on the $28^{\text {th }}$ of June 1916, edited by Kossovo Day Committee, 29-31. London: Vacher \& Sons.

Bagarić, Oliver. 2008. “Museum und nationale Identitäten: Eine Geschichte des Landesmuseum Sarajevo [Museum and National Identities: A History of the Regional Museum in Sarajevo]." Südost-Forschungen 67: 144-167. 
Bohemian Blog. 2016. “A Field of Blackbirds: Dark Tourism in Kosovo's Former Conflict Zones." The Bohemian Blog. January 31, 2016. http://www.thebohemianblog. com/2016/01/a-field-of-blackbirds-dark-tourism-in-kosovos-former-conflictzones.html.

Bone, James. 1915. "Meštrović and his art." In Exhibition of the Works of Ivan Meštrović. London: Victoria \& Albert Museum.

Chesterton. G.K. 1917. "A thing called a nation: The spiritual issue of the war." In The Lay of Kossovo. Serbia's Past and Present (1389-1917), edited by F.W. Harvay, C. Oman, Sir Arthur Evans, T.R. Djordjevitch, Alice and Claude Askew, G.K. Chesterton, and The Three Ballads. For the Anniversary of the Kossovo Day Celebration in Great Britain on the 28th of June, 1916, published by the Kossovo Day Committee, 32-35. London: Kossovo Day Kommittee.

Cronin, Elisabeth. 2015. Heimatfotografie in Österreich. Eine politisierte Sicht von Bauern und Skifahrern (Heimat Photography in Austria. A Politicized View of Farmers and Skiers). Wien: Fotohofedition.

Cultural monuments in Serbia: National Center for Digitalization. Church St. Lasarus, http://spomenicikulture.mi.sanu.ac.rs/spomenik.php?id=27. Accessed January 20, 2018.

Clegg, Elisabeth. 2002. "Meštrović, England, and the Great War." The Burlington Magazine 144: 740-751.

Darré, Walther R. [1929] 1942. Das Bauerntum als Lebensquell der nordischen Rasse [The Paesantry as a Source of Life for the Nordic Race]. München: J.F. Lehemanns Verlag.

Durham, Mary Edith. 1904. Through the Land of Serbs. London: Edward Arnold.

- - - 1905. The Burden of the Balkans. London: Edward Arnold.

- - . 1909. High Albania. London: Edward Arnold.

Fromm, Carl Jos. 1900. "Bosnien und die Hercegowina auf der Pariser Weltausstellung [Bosnia and Hercegovina at the Paris World's Fair]." In Die Pariser Weltausstellung in Wort und Bild, edited by Georg Malkowsky, 448-455. Berlin: Verlag Kirchhoff $\&$ Co.

Giesen, Bernhard. ${ }^{32} 2016$. Kollektive Identität. Die Intellektuellen und die Nation 2. Frankfurt am Main: Suhrkamp.

Grigorovich, V.I. 1916. Donesenia V.I. Grigorovicha ob ego puteshestvii po slavjanskim zemljam [Reports V.I. Grigorovich's on his Journey through the Slavic lands]. Kazan': Izdanie otdelenija russkago jazyka i slovesnosti Impertorskoj akademii nauk.

Grimm, Hans. 1934 [1926]. Volk ohne Raum [People Without Space]. München: Albert Langen/Robert Müller. 
Hajdarpasic, Edin. 2015. Whose Bosnia? Nationalism and Political Imagination in the Balkans, 1840-1914. Cornell University Press.

Halbwachs, Maurice. 2003. Stätten der Verkündigung im Heiligen Land [Places of Annunciation in the Holy Land]. Konstanz: UVK Verlagsgesellschaft.

Heimstedt-Vaid, Petra. 2004. "Rezeption der serbischen Volkslieder und ihrer Übersetzungen in der deutschen Presse in der ersten Hälfte des 19. Jahrhunderts [Reception of Serbian Folk Songs and their Translations in the German Press in the First Half of the 19th Century]." Zeitschrift für Balkanologie 40: 121-139. Hübner, Kurt. 1985. Die Wahrheit des Mythos, München: C.H. Beck.

Interview Memorandum from 29th Mai 1915. Recorded by Mr. Maclagan. Archive of Victoria \& Albert Museum (Blythe House), London.

Kalaj [Kállay], Benjamin. 1885. Rusija na Istoku: Istorichka crta [Russia in the East: Historical Sketch]. Novi Sad.

Koch, Elke, and Heike Schlie. 2016. "Einleitung [Introduction]." In: Orte der Imagination - Räume des Affekts: Die mediale Formierung des Sakralen [Places of Imagination - Spaces of Affect: The Medial Formation of the Sacral], edited by Elke Koch and Heike Schlie, 9-18. Paderborn: Wilhelm Fink.

Kozljanič, Robert Josef. 2004. Der Geist des Ortes. Kulturgeschichte und Phänomenologie des Genius Loci. 1. Bd.: Antike - Mittelalter [The Spirit of the Place: Cultural History and Phenomenology of the genius loci. vol 1: Antiquity - Middle Ages]. München: Albunea.

Kožančikov, D.E., ed. 1873. Sobranie sočinenij A. Gil'ferdinga, tom tretij: Bosnija, Gercegovina i Staraja Serbija [Collected works by A. Gil'ferding, vol 3: Bosnia, Hercegovina and Old Serbia]. St. Petersburg.

Lendvai-Dircksen, Erna. 1936. Bergmenschen [Mountain People]. München: Verlag F. Bruckmann AG.

-_- 1937. Das Gesicht des deutschen Ostens (The Face of the German East). Berlin: Zeitgeschichte, Verl. und Vertriebs-GmbH.

-_- [1940?]. Wanderdünen. Bilder einer Urlandschaft [Shifting Dunes: Pictures of Primeval Nature]. Bayreuth: Gau-Verlag Bayerische Ostmark.

Lindemann, Kristin. 2015. “Literatur im Dienste der Modernisierung: BosnienHerzegowina im Kontext des islamischen Aufklärungsdiskurses [Literature in the Service of Modernization: Bosnia-Herzegovina in the Context of the Islamic Enlightenment Discourse].“ PhD diss. University of Konstanz. https://d-nb. info/1115727125/34. 
Lipták, Lubomír. 2003. “Die Tatra im slowakischen Bewusstsein [The Tatra in the Slovak consciousness]". In Heroen, Mythen, Identitäten. Die Slowakei und Österreich im Vergleich [Heroes, Myths, Identities: Slovakia and Austria in Comparison], edited by Hannes Stekl and Elena Mannová, 261-288. Wien: Facultas.

Lovrenović, Dubravko. 2008. Povijest est magistra vitae: O vladavini prostora nad vremenom [History is magistra vitae: About the Domination of Space over Time]. Sarajevo: Rabic.

Mackenzie, Giorgina Muir, and Adelina Paulina Irby. 1877. Travels in the Slavonic Provinces of Turkey-in-Europe. With a Preface by the Right Hon. W.E. Gladstone, M.P. London.

Masaryk, T.G. [1917?]. "The Problem of Small Nations." In The Voice of an Oppressed People, edited by Bohemian National Alliance, 5-23. Chicago: Bohemian National Alliance.

Milojković-Djurić, Jelena. 2000. “Benjamin von Kállay's Role in Bosnia-Herzegovina 1882-1903: Habsburg's Policies in an Occupied Territory." Journal of the North American Society for Serbian Studies 14 (2): 211-220.

Okey, Robin. 2007. Taming Balkan Nationalism: The Habsburg 'Civilizing Mission' in Bosnia, 1878-1914. Oxford: Oxford University Press.

Paton, Andrew Archibald. 1845. Servia, the Youngest Member of the European Family: or, a Residence in Belgrade, and Travels in the Highlands and Woodlands of the Interior, During the Years 1843-1844. London: Longman, Brown, Green, and Longmans.

Perica, Vjekoslav. 2002. Balkan Idols. Religion and Nationalism in Yugoslav States. Oxford: Oxford University Press.

Preindlsberger-Mrazović, Milena. 1908. Die bosnische Ostbahn. Illustrierter Führer auf den bosnisch-hercegovischen Staatsbahnlinien Sarajevo-Uvac u. MegjegjeVardište. Wien: A. Hartleben's Verlag.

Reynolds, Diana. 2014. "Zentrum und Peripherie: Hegemonialer Diskurs oder kreativer Dialog [Center and Periphery: Hegemonic Discourse or Creative Dialogue]." In: Vernakulare Moderne: Grenzüberschreitungen in der Architektur um 1900: Das Bauernhaus und seine Aneignung (Vernacular Modernity: Crossing Boundaries in Architecture Around 1900: The Farmhouse and its Appropriation), edited by Anita Aigner, 85-116. Bielefeld: Transcript.

Schama, Simon. 1995. Landscape and Memory. New York: Knopf.

Schmitt, Carl. [1942] 2018. Land und Meer. Eine weltgeschichtliche Betrachtung [Land and see: A world-historical consideration]. Stuttgart: Klett-Cotta. 
Strunz, Franz. 1939. “Das Heimweh: Zur Psychologie und Geschichte des germanischen Naturgefühls [Homesickness: On the psychology and history of the Germanic sense of nature]." Sudhoffs Archiv für Geschichte der Medizin und der Naturwissenschaften 32: 137-154.

Sundhaussen, Holm. 1999. “Kosovo: ‘Himmlisches Reich' und irdischer Kriegsschauplatz: Kontroversen über Recht, Unrecht und Gerechtigkeit [Kosovo: 'Heavenly Kingdom' and earthly theater of war: Controversies about law, injustice and justice]." Südosteuropa. Zeitschrift für Gegenwartsforschung 48: 237-257.

-_-. 2000. "Kosovo - Eine Konfliktgeschichte [Kosovo-a conflict history]." In Der Kosovo-Konflikt: Ursachen, Verlauf, Perspektiven [The Kosovo conflict: Causes, course, perspectives], edited by Konrad Clewing and Jens Reuter, 65-88. Klagenfurt: Wieser.

-_- 2014. Sarajevo: Die Geschichte einer Stadt [Sarajevo: The story of a city]. Wien: Böhlau.

Ubiparip, Milanka. 2017. "Miscellany: Inscription on the marbele pillar in Kosovo." In: Serbian Artistic Heritage in Kosovo and Metohija: Identity, Significance, Vulnerability, edited by Dušan Otašević, Miodrag Marković, and Dragan Vojvodić, 248-251. Belgrade: Academy of Sciences and Arts.

Valena, Tomáš. 2009. "Zu einer Phänomenologie des Genius Loci [To a phenomenology of the genius loci]." In Genius Loci: Der Geist von Orten und Landschaften in Geomantie und Architektur [Genius loci: The Spirit of Places and Landscapes in Geomancy and Architecture], edited by Lara Mallien and Marco Bischof, 148205. Klein Jasedow: Drachen.

Wachtel, Andrew Baruch. 1998. Making a Nation, Breaking a Nation: Literature and Cultural Politics in Yugoslavia. Stanford: Stanford Univ. Press.

Warnke, Martin. 1992. Politische Landschaft: Zur Kunstgeschichte der Natur [Political Landscape: The Art History of Nature]. München: Hanser.

Wellek, René. 1959. “Hyppolite Taine's Literary Theory and Criticism.” Criticism 1 (1): $1-18$.

Zimmermann, Tanja. 2010a. "Titoistische Ketzerei: Die Bogomilen als Antizipation des ,dritten Weges' Jugoslawiens [Titoist heresy: The Bogomils as Anticipation of the 'Third Way' of Yugoslavia]." Zeitschrift für Slawistik 55 (4): 445-463.

- - . 2010b. "From the Haiducks to the Bogomils: Transformation of the Partisan Myth after World War II." Kino! Partizanski film 10: 62-70.

- - - 2012. "The Voice of Gusle and its Resistence against Electrification." In Electrified Voices: Medial, Socio-Historical, and Cultural Aspects of Voice Transfer, edited by Nils Meise and Dmitri Zakharine, 403-410. Göttingen: Vandenhoeck \& Ruprecht. 
--_. 2014a. Der Balkan zwischen Ost und West. Mediale Bilder und kulturpolitische Prägungen [The Balkans between East and West. Media Images and CulturalPolitical Imprints]. Köln: Böhlau.

- - . 2014b. "Ausstellungswesen und transnationales nation building im Ersten und Zweiten Jugoslawien [Exhibiting and Transnational Nation Building in the First and Second Yugoslavia]." In Brüderlichkeit und Bruderzwist: Mediale Inszenierungen des Aufbaus und des Niedergangs der multinationalen Staaten in Ost- und Südosteuropa [,Brotherliness' and ,Fraternal Strife': Media Enactments of the Rise and Fall of Political Communities in Eastern and South-Eastern Europe], edited by Tanja Zimmermann, 231-246. Göttingen: Vandenhoeck \& Ruprecht

-_-. 2014c. “Die Schlacht auf dem Amselfeld im Spiegel der internationalen Politik: Permutationen eines panslawistischen Mythos vom 19. bis ins 21. Jahrhundert [The Battle of the Blackbird Field in the Mirror of International Politics: Permutations of a Pan-Slavic Myth from the 19th to the 21st Century]." In Post-Panslawismus: Slavizität, Slavische Idee und Antislavismus im 20. und 21. Jahrhundert? [Post-pan-slavism: Slavicity, Slavic Idea and Anti-slavism in the $20^{\text {th }}$ and $21^{\text {st }}$ Centuries?], edited by Agnieszka Gąsior, Lars Karl, and Stefan Troebst, 289-305. Göttingen: Wallstein.

-_- 2014d. "Mediatized Prayer and the Politicized Nation." In Historia artis magistra: amicorum discipulorumque munuscula Johanni Höfler septuagenario dicata, edited by Renata Novak Klemenčič, 413-418. Ljubljana: Filozofska fakulteta.

_-_. 2016a. “Antimodernismus oder modernistische Retroavantgarde? Paradoxien der Moderne in Südosteuropa [Antimodernism or Modernist Retro AvantGarde? Paradoxes of Modernism in Southeastern Europe]." In Laboratorien der Moderne. Orte und Räume des Wissens in Mittel- und Osteuropa, edited by Bernd Stiegler and Sylvia Werner, 289-310. München: Wilhelm Fink.

- - . 2016b. “'Wenn noch irgendein 'Balkan' im früheren Sinne dieses Wortes existiert, dann bestimmt nicht hier auf dem Balkan': Archaisierung und Antikisierung im Kampf gegen den Orientalismus ["If any 'Balkans' still exist in the earlier sense of the word, then certainly not here in the Balkans": Archaization and Antiquization in the fight against the Orientalismus]." In: "Den Balkan gibt es nicht": Erbschaften im Südosten Europas ["The Balkans do not exist": Inheritance in the Southeast of Europe], edited by Martina Baleva and Boris Previšić, 121-141. Wien: Böhlau. 
Zirojević, Olga. 1998. “Das Amselfeld im kollektiven Gedächtnis [The Fiel of Blackbirds in The Field of Blackbirds in the collective memory]." In Serbiens Weg in den Krieg. Kollektive Erinnerung, nationale Formierung und ideologische Aufrüstung [Serbia's Way to War: Collective Memory, National Formation and Ideological Rearmament], edited by Thomas Bremer, Nebojša Popov, and Heinz-Günther Tobbe, 45-61. Berlin: Berliner Wissenschafts-Verlag. 


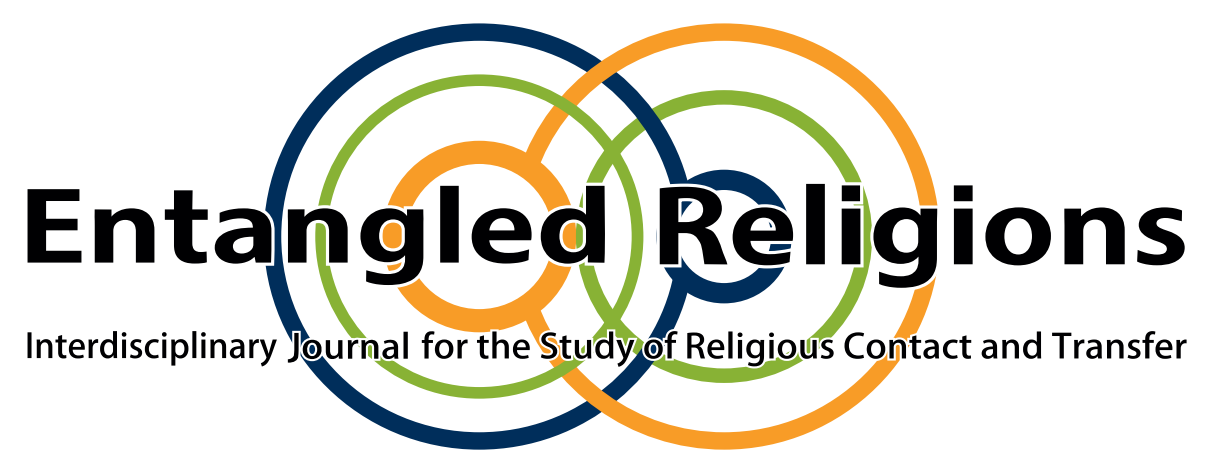

\section{Shared Shrines and the Discourse of Clashing Civilisations}

\section{GLENN BOWMAN}

Emeritus Professor of Socio-Historical Anthropology, School of Politics and International Relations, University of Kent, England

This contribution to Entangled Religions is published under the Creative Commons Attribution 4.0 International Public License (CC BY 4.0 International). The license can be accessed at https://creativecommons.org/licenses/by/4.0/legalcode.

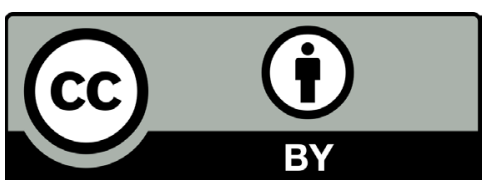

Entangled Religions 9 (2019) http://doi.org/10.13154/er.v9.2019.108-138

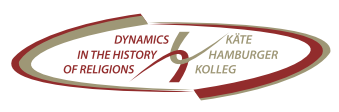




\title{
Shared Shrines and the Discourse of Clashing Civilisations
}

\author{
GLENN BOWMAN
}

University of Kent

\begin{abstract}
Since I began, in the early 1980s, to research Muslim-Christian cohabitation of religious sites, I have been convinced of the political importance of making practices of intercommunal 'sharing' ethnographically visible. Thirty-five years of that work, spread across the Eastern Mediterranean (Israel/ Palestine, Yugoslavia and its successor states, and both sides of the Cyprus divide), have not only revealed contemporary and historical choreographies of cohabitation but also their disintegration and the forces which bring it about. While I was carrying out this research, an accelerating resurgence of ethnic, religious and nationalistic politics was taking place not only throughout the areas I was studying but also in the global arena. This 'identitarian' politics, its philosophical grounding, and its shaping of academic and popular thought and practice is the focus of the first half of this paper; in the second part I look theoretically and empirically into examples of sharing and its refusal so as to show not only how cohabitation with alterity works but also to make visible the processes which sabotage it.
\end{abstract}

KEY WORDS Intercommunal relations; shrines; identity; space; place; clash

of civilisations; discourse; commensality; antagonism

\section{Introduction ${ }^{1}$}

Over the past couple of years, events have taken place that foreground the importance of the material addressed in this article. The referendum on the U.K.'s membership in the European Union, called in order to protect David Cameron's prime ministership from the right wing of the Tory party, gave rise to a heated debate about the place of 'foreigners' in Great Britain, culminating in a contentious decision to avoid the immigration of others, regardless of what such avoidance might cost. Across the Atlantic, the vitriolic rhetoric of Donald Trump and his fellow travellers, again focussing on the need to protect an ill-defined 'us' from a threatening 'them', gave the presidency of the most powerful state in the world to a man promising to exclude Muslims, expel immigrants, and build walls against territorial neighbours. In France, Holland, Hungary, and elsewhere in Europe a populist nationalism has burgeoned, threatening to erode, if

1 A section of this paper is drawn from an earlier text, Bowman 2016, published by Berghahn Books. 
not eradicate, the progressive gains that the West, and with it much of the world, has enjoyed since the end of the Second World War.

\section{Constructing Others}

One of the more troubling aspects of these events is that the 'Other' against which people turn is not simply that of a territorial outside deemed antagonistic but is as well made up of people and communities living in contiguity with those who have come to see them as threatening and unwelcome. Trump's proposed deportation orders refer to 'illicit' residents who, in many cases, have been born and raised to adulthood in the USA, while in the UK, as in France, Holland, and elsewhere in contemporary Europe, people who have been long integrated into those countries and their local communities are targeted by politicians and governmental agencies that question, and often delegitimate, their rights to be there. Undeniably, there are people who repeat and amplify the antagonistic messages accompanying and promoting these events. Some of these have always been around, nursing their antipathies in silence or manifesting them under the cover of media darkness, but, as recent surges of racialist and sectarian attacks have shown, the normalisation of discourses of intolerance and hatred gives legitimacy to their rage and encourages them to emerge from the shadows to call on others to take up their crusade. As those discourses proliferate and are subtly or not so subtly legitimated by governmental, academic, and media dissemination, calls to neighbour hatred come to seem increasingly commonsensical and anything but marginal.

Outbreaks of intolerance and hatred are not simple expressions of primordial antagonisms, despite what Robert Kaplan (1993) has suggested with reference to the wars in Yugoslavia. In the case of most if not all of the countries mentioned above, contemporary nationalisms are recent constructions produced by discursively amalgamating a number of different communities (and excluding others). However, even where the sectarian and religious identifications that morph into nationalist identities are historically well established-as may arguably have been the case in now Former Yugoslavia-it is quite evident that those histories are marked by long-term commensality with ethnic or sectarian Others, operating with a range of intensities (Baskar 2012; Henig 2012; Sorabji 2008).

Commensality can nonetheless, in certain contexts, disintegrate into intercommunal antagonism. ${ }^{2}$ What is vital to consider in investigating such outbreaks is what it is

2 See, for powerful illustrations of this, Tone Bringa's film “We Are All Neighbours" directed by Debbie Christie for ITV's Disappearing World (Bringa 1993) as well as Pretty Village, Pretty Flame (Lepa sela 
that disrupts everyday interaction and brings about intercommunal antipathies and violence. I have argued with reference to Yugoslavia and Israel/Palestine (Bowman 2003) that such eruptions are discursively prepared and, once effected, maintained in a feedback loop through which images of the dangerous Other are amplified and circulated by narratives rendering those images verisimilitudinous. Certainly, gruesome reports of ISIS violence as well as images of waves of Islamic refugees crashing against the borders of the nation state (even if, in the case of the most powerful picture in the bank of UKIP propaganda, those borders belonged to Slovenia and Croatia rather than the U.K.) made visceral the threat many had come to feel in the face of what they were told to see as encroaching Islam. These images, moreover, served for many simply to confirm pre-existing opinions about the danger not only of Islam but of cultural alterity full stop (blacks, Mexicans, Eastern Europeans, etc.). These opinions, I contend, were fomented by two decades or more of intellectual debate and media dissemination of identitarian arguments about the impossibility of living with 'others'.

\section{The Clash of Civilisations}

The extensibility of the image of the threatening Other testifies to a paradigm shift which, for illustrative reasons, I will trace back to the impact of Samuel Huntington's hypothesis of a 'clash of civilisations' (Huntington 1993, 1996), although it must be acknowledged not only that Huntington's argument was not original, having precursors in the work of orientalists such as Bernard Lewis (Lewis 1990), but also that other forms of identitarianism were simultaneously gaining in popularity. ${ }^{3}$ Huntington's thesis is too well known to need reiterating at length, but it can be summed up in a selection of quotes from his original Foreign Affairs article:

lepo gore) 1996, director Srdan Dragojevic, a fiction film produced in Belgrade soon after the end of the War of Yugoslav Seccession.

3 Consider here Alain Badiou's argument that the advent of the 1980s marks the end of a short century of a multitude of radical collective wills to transformation that is followed by the decades in which he writes (and in which we continue to live) marked by "the dominance of an artificial individualism" (Badiou 2007, 98). Badiou writes that "if you think the world can and must change absolutely; that there is neither a nature of things to be respected nor pre-formed subjects to be maintained, you thereby admit that the individual may be sacrificable....The individual is not independently endowed with any intrinsic nature that would deserve our striving to perpetuate it" (ibid., 99). The contemporary alternative sanctifies the will of the individual encased in its identity and thus-despite the individuality of its apparent narcissism-locks the individual into the collectivity of cultural being. This is an ontological conservatism: "there is a 'nature of things' and violence must not be done to it" (ibid.). 
The fault lines between civilizations will be the battle lines of the future... differences among civilizations are not only real; they are basic. Civilizations are differentiated from each other by history, language, culture, tradition and, most important, religion. The people of different civilizations have different views on the relations between God and man, the individual and the group, the citizen and the state, parents and children, husband and wife, as well as differing views of the relative importance of rights and responsibilities, liberty and authority, equality and hierarchy. These differences are the product of centuries. They will not soon disappear. They are far more fundamental than differences among political ideologies and political regimes. (Huntington 1993, 23 and 25)

Huntington's argument for conflictual civilizational difference is primarily territorialist, positing spatial differentiation between 'civilisations' entailing “bloody borders" (1993, 35) as well as "fault lines between civilizations" (1993, 29ff). This not only makes for conceptual problems in areas where 'civilisations' are mixed without conspicuous bloodshed but also in understanding displacements, diasporas, and migrations that 'mix' civilisations in the same territories. Furthermore, the clash of civilisations argument is simultaneously profoundly essentialist and deeply 'groupist' (see Brubaker 2002 , 164ff). Referring to the core example he poses of inter-civilisational antagonism, Huntington writes that "conflict along the fault line between Western and Islamic civilizations has been going on for 1,300 years" (1993, 31). This temporal continuum from the defeat of Justinian II at Sebastopolis (692 C.E.) to the emergence of political Islam in Algeria and Central Asia (Kazakhstan, Kyrgyzstan, Tajikistan, Turkmenistan, and Uzbekistan) in the early $1990 \mathrm{~s}^{4}$ erases social and political processes (and with them history per se) while at the same time downplaying diversity and antagonism within 'civilisational groups'.

'Groupism', which Brubaker defines as a "tendency to take bounded groups as fundamental units of analysis (and basic constituents of the social world)" (2004, 2), results, in Huntington's analysis, in constituting civilisational 'communities' as transhistorical entities melding together all those who identify with what we can finally only see as a name. Hence a civilisation is

the highest cultural grouping of people and the broadest level of cultural identity people have short of that which distinguishes humans from other species. It is defined both by common objective elements, such as language, history, religion,

4 See Robin Wright's "Islam, Democracy and the West”, published a year earlier than Huntington's article in the same journal, for a far more nuanced and less confrontational take on Islam and the West at that historical moment (Wright 1992). 
customs, institutions, and by the subjective self-identification of people. People have levels of identity: a resident of Rome may define himself with varying degrees of intensity as a Roman, an Italian, a Catholic, a Christian, a European, a Westerner. The civilization to which he belongs is the broadest level of identification with which he intensely identifies. (Huntington 1993, 24)

For Huntington that 'intense identification' is at the core of civilisational identity, but investigation shows that the object of such identification (say 'Islam') will, while retaining its nominal identity, vary its meaning depending on which community (or even individual) is identifying with it in what historical period. Huntington's Islam, for instance, effaces the distinctions between and within communities (not to mention individuals) of Shi'a and Sunni Muslims while simultaneously discounting differences between Salafists, the many Sufi orders, and diverse other forms of Islam (cf. Gilsenan, 1982). Here the object of identification — the name 'Islam' - is what Kripke, Peirce, and others have termed a 'rigid designator'. Peirce describes its construction in personal terms: "I believe in mooring our words by certain applications and letting them change their meaning as our conceptions of the things to which we have applied them progress" (Charles S. Peirce, A Treatise on Metaphysics, 1861-1862, quoted in Short 2007, 264). ${ }^{5}$ Peirce's idea that nominatives might retain their form while shifting their meanings as changing experience so necessitates can easily be extended beyond personal histories to those of communities scattered in their diversity and developing over time while retaining nominal allegiance to a term of identification, such as Islam. As, obviously, that locus of identification mutates, so, too, do the antagonisms posited as fixed by identitarian essentialists such as Huntington. One Muslim, living in the same community as another, may feel an abiding hatred for all things 'Western' based on her interpretation of 'Islam', while a neighbour, similarly attesting full identification with Islam, might find Western lifestyles and Western neighbours attractive and compatible. ${ }^{6}$

5 What Peirce describes is an "initial baptism" (Kripke 1980, 96-97 and passim) whereby a word is linked to a reference prior to being passed on to different contexts along a chain of communication, in the course of which the reference shifts yet is still indicated by the same word. Žižek, parsing Kripke, writes that "it is the word which, as a word, on the level of the signifier itself, unifies a given field, constitutes its identity. It is, so to speak, the word to which 'things' themselves refer to recognize themselves in their unity.... It is not the real object which guarantees as the point of reference the unity and identity of a certain ideological experience-on the contrary it is the reference to a 'pure' signifier which gives unity and identity to our experience of historical reality itself" (Žižek 1989, 95-96 and 97, see also Kripke 1980 and Vološinov [1929] 1973, 79-80).

6 A dramatic example of this is the BBC2 series Muslims Like Us (directed by Fatima Salaria), screened on 5 and 12 January 2017. 
Such contemporary responses will differ substantially from earlier manifestations of Islamic belief and practice.

\section{Promoting Identitarianism}

Despite Huntington's model's conceptual weaknesses, it has proved highly influential in shaping both political and popular thinking about Islam in particular and alterity in general: Richard Bonney $(2008,35)$ asserts that "no thesis has had a comparable influence on Western, especially American, strategic thinking since the end of the cold war." It has certainly become an academic and popular touchstone for discussions on cultural identities and antagonisms. From what does such influence devolve?

Jane Mayer, an investigative journalist associated with The New Yorker, published Dark Money in 2016 (Mayer 2016a). Here, she argues that John M. Olin, through his Olin Foundation and with the cooperation of a number of other private foundations, "funded the creation of a conservative counter-intelligentsia...to reorient the slant of American higher education to the right" (Mayer 2016a, 94 and 93, see also Spring 2010, 121150). The Olin Foundation funded professors at influential universities throughout the country, among them Milton Friedman (Free to Choose, 1980), Charles Murray (Losing Ground: American Social Policy 1950-1980, 1984; and, with Richard Herrnstein, The Bell Curve: Intelligence and Class Structure in American Life, 1994), Allan Bloom (The Closing of the American Mind, 1987), Dinesh D'Souza (Illiberal Education, 1991), and John R. Lott Jr. (More Guns, Less Crime, 1998). The resultant (often disputed) scholarship was not only disseminated via academic channels but also massively amplified by the attention given to its media and political promotion. Thomas Medvetz, in his Think Tanks in America, examines the extensive promotional efforts invested in Charles Murray's Losing Ground to exemplify the ways that right wing institutes promote the work they have funded (Medvetz 2012, 1-5). Murray, commenting on the way his book went from being a radical outlier assault on welfare to being the "compulsory point of reference" (quoted in ibid., 5) in political discussions, noted that "it took ten years for Losing Ground to go from being controversial to conventional wisdom. And by the way there is very little in Losing Ground right now that's not conventional wisdom" (quoted in ibid.). ${ }^{7}$

7 Lawrence Mone, director of the Olin-funded Manhattan Institute for Policy Research, commented that Losing Ground "captured the strategic audience,...journalists who could reframe the terms of the debate. Charles targeted this audience and his book hit the bull's eye.... Slowly but surely over the course of the next ten years, it totally flipped the conventional wisdom on welfare. And that flip led ultimately to the welfare reform bill of 1996" (Interview, 14 June 2004 in Medvetz 2012, 241). 
In 2005, Lawrence Mone told Lizzy Ratner of The Observer that "the Olin Foundation was one of the two or three major conservative foundations that laid the intellectual infrastructure of what we see today" (Ratner 2005, unpaginated). One of the primary beneficiaries of the Olin Foundation's programme of "taking the liberal out of liberal arts education" (Mayer 2016, 104) was Samuel Huntington, who received 8.4 million dollars from the Foundation to establish and run his "hawkish" (Mayer 2016b, unpaginated). John M. Olin Institute for Strategic Studies at Harvard that sponsored 88 fellows between 1990 and 2001, 56 of whom took up professional academic careers at prestigious and Ivy League universities while others "became public figures in government, think tanks, and the media" (Mayer 2016b, unpaginated). ${ }^{8}$ Huntington and the Olin Foundation generated what I would argue was a significant shift in how identities and communities were conceptualised in both popular and academic discourses, and that influence spread far beyond the direct reach of both funding and patronage.

\section{Civilisations Clashing on Shared Religious Space}

The 'clash of civilisations' discourse promoted by Huntington and the Olin Foundation impacted powerfully_directly and indirectly-on scholarship, particularly in the United States. One of the significant sites of this impact was the debate on the 'sharing' of religious space. Ron Hassner argues in War on Sacred Grounds (2009) as well as in “The Pessimist's Guide to Religious Coexistence" (2010) that "sacred places cannot be shared" (Hassner 2009, 3):

The very same motivations that lead religious groups to attribute importance to sacred sites also lead these groups into conflict with religious rivals at these sites.... [T] he key to resolving religious conflict at sacred sites lies not in managing tensions between rival groups but in separating those groups from one another. (Hassner 2010, 146-147)

Hassner claims to find "the optimistic attitude that characterizes current research on inter-religious strife...nothing short of baffling" (ibid., 146) but writes it off as "part of a larger backlash against the pessimistic stance that has dominated the study of religion and politics since the publication of Samuel Huntington's Clash of Civilizations" (ibid.). Intriguingly, Hassner was, in 2003 and 2004, a Harvard post-doctoral fellow at 
Huntington's Olin Institute for Strategic Studies. ${ }^{9}$ His arguments for the centrality of religious identity in both the sharing of place and mobilisation for war (see his 2016 Religion on the Battlefield, Cornell) are profoundly civilisational.

Robert Hayden diverges significantly from the position put forward by Hassner, arguing that while for Hassner centrality refers to a site's "space in the spiritual landscape' of the religious community concerned" (Hayden 2016, 81) for him a holy place's "centrality refers to [its] location within a settlement or perhaps proximity to locations of important economic or political activity" (ibid., 720). What is signal for Hayden is the 'perceptibility' of the markers of another's presence in the holy place; a relatively low profile does not pose a threat to the community which holds the site, and the presence can be tolerated whilst a more eminent presence threatens and demands expulsion. Antagonism for Hayden depends on a notable threat to hegemony rather than one to sanctity; violence is "likely only when dominance is under contention and must be either acquired or (re)inforced" (Hayden 2015, 70).

Hayden has been critical of the clash of civilisations model, arguing that it "exemplif[ies] the 'cultural fundamentalism' that seems to be replacing classical racism as a rhetoric of exclusion" (Hayden 2000, 118 n3). Furthermore, the funding for his work on shared shrines has come not from Olin Foundation or other right-wing think tanks but from the National Science Foundation and the Wenner-Gren Foundation. ${ }^{10}$ Nonetheless, significant aspects of identitarian argumentation are present in his readings of intercommunal interactions around holy places, and these, I feel, have shaped his interpretations of shrine contestation. The association depends less on the 'civilisational' matter central to the Huntingtonian approach than in the groupism Brubaker has shown to be an essential element of identitarian arguments. Contesting my point that "religious sites and practices [are] maintained by and closely articulated with local populations [and]...such local sites can...be seen to reflect and amplify images of the consociality of the communities that surround, or had surrounded, them" (Bowman 2012c, 5), Hayden and his colleagues argue that

analyzing specific sites as if they were at least semi-isolated from larger religious, social, and political networks is inherently misleading. No matter how syncretic a site may seem at some moment, the people going there...are still connected to larger, non-local religious communities and their associated identities, and may

See his CV at http://polisci.berkeley.edu/people/person/ron-hassner (last accessed 2 February 2019).

10 Reputable institutions that, despite their probity, are vulnerable to influence from the encompassing intellectual milieu through peer refereeing and other determinants of selection. 
draw on these wider connections. In fact, much of our work is oriented towards analyzing how and when such extra-local ties are invoked. (Hayden et. al. 2016, 42)

Neither I nor others criticised by Hayden as naïve advocates of intercommunal sharing have denied that contests may come up between representatives of the varied groups 'sharing' shrines and that, in these contests, advocates of either group's hegemonic claims are likely to call on the support of co-religionists in the wider context. We have, however, made it clear that the groups sharing sites are not themselves unitary and that members sharing nominal allegiance are themselves very likely to dispute amongst themselves whether local ties with neighbours should be maintained or whether outside powers should be drawn in to reject them. The issue of who invokes extra-local ties and how that invocation is received seems a salient part of ethnographic description and raises the very central question of the relative autonomy of neighbourhoods and the associations they generate. This 'interference' is one salient way in which local (or 'micro' level) events are impacted by developments and discourses on the 'macro' level of national and global politics or institutional debates.

The antagonistic tolerance argument seems, however, to ignore such 'minutiae,' asserting that when dominance is seen to be challenged, the 'community' mobilises as a unitary entity: "religion may be the key identifying factor associated with a community and thus accepted as defining that group as opposed to others" (Hayden 2015, 70). Regardless of whether the members of a community engaging in intercommunal sharing choose, against the wider context, to continue to identify themselves with the diversity of their community (see Bigelow 2010), whether, as in the examples developed by Hayden and his colleagues in their works $(2002,2015,2016)$, they group as unitary communities to struggle against their neighbours for ownership of the sites, or whether, as in the case studied by Rohan Bastin (2012), religious authorities intervene to expunge signs of sharing despite the resistance of the mixed communities, what is important to discern, describe, and analyse is the politics of antagonism or accommodation. An identitarian approach which takes communal identity as a given, waiting latently to be 'switched on' by a change in the balance of power, prevents examination of the real play of politics in the same way that, in the clash of civilisations approach, the diversity of communities and their historical interactions within a 'civilisation' are rendered insignificant. 


\section{Choreographies of Cohabitation}

Investigations of cohabitation of shrines that are not based on identitarian models tend, for the most part, to be anthropological and/or historical and to be empirically based around case studies. ${ }^{11}$ To date a model has not emerged from this work, but that is perhaps for the better insofar as one of the chief findings of this research is that identity cannot be approached as fixed or groupist. These studies have demonstrated that peaceful intercommunal cohabitation around sacred sites exists, or has existed, although none have asserted that the willingness to share with others is an essential, necessarily durable, human characteristic. However, insofar as the focus of these studies has, in most of these cases, been limited to moments or periods of intercommunal interactions in and around the sites themselves, they might be seen, in their concern with amenable sharing, as being similar in their supposed essentialism to those that argue for an inbuilt competitive antagonism.

Hayden, for instance, criticises "inherently static and essentialist forms of analysis" (Hayden 2016, 84) that focus "on a particular combination of circumstances at a particular moment in time" (ibid., 83) as being, in effect, "structural-functional...and unable to handle social change" (ibid.). He faults the critics of his AT (antagonistic tolerance) model for failing to see that sacred sites are "inherently linked to social processes that are larger than the purely local" (ibid., 84) and asserts that

ethnography alone is inadequate to explain the relations between local groups even at the time when observations were made, unless the events analysed are contextualized in a trajectory of interactions between the religious communities concerned-communities not only at the local level but more widely as well. (ibid., 84-85)

11 For a partial listing in English of the anthropological material see Albera and Couroucli 2012; Barkan and Barkey 2014; Bigelow 2003, 2010, and 2012; Bowman 1993, 2012a, 2012b, 2012c, 2013a and 2013b; Cormack 2013; Couroucli 2009 and 2010; Driessen 2012; Koneska 2013; Lubańska 2013 and 2015; and Valtchinova 2012 and for the historical Barkey 2008: 109-153; Cuffel 2003, Fowden 1999 and 2002; and Meri 1999 and 2002. Also Lieux Saints Partagés (Albera, Penicaud and Marquette 2015), the catalogue of an exhibition on shared sites hosted by the Marseille's Mucem (Musée des civilisations de l'Europe et de la Méditerranée) and http://sharedsacredsites.net/sharedsacredsites. net, "a collaborative project that seeks to develop a rubric for the description, classification, analysis, and publication of work relating to spaces and locations used by multiple, disparate communities for religious purposes" (no pagination). Hassner and Hayden do, of course, mobilise specific site studies drawn from both ethnographic observation and historical research, but these serve to exemplify the tenets of general models rather than as starting points for processes of inductive reasoning. 
Although sophisticated work bringing together ethnographic and historical research, such as that of Anna Bigelow, ${ }^{12}$ certainly cannot be charged with either not handling social change or failing to link up with processes larger than the local, it is true that emphasis on the 'local' and the 'ethnographic present' within the specific context of sacred places enables the advocates of the AT position to charge the 'sharers' with a degree of political naivety. That focus, however, and the attention to the details of interpersonal and intercommunal interaction it enables, serves to highlight the dynamics of relations in and around a site, to interrogate the changing discourses operative in those situations, and to investigate what enables and what disrupts 'mixing' (cf. Bowman 2012 and Lubańska 2015). It also avoids the de-differentiation central to arguments such as Hayden's, for instance, which talks of "interactions between the religious communities...not only at the local level, but more widely as well" (Hayden 2016, 85) as though all the members of a nominal religious groupfrom, in Christian cases, laypersons through to priests and patriarchs-can be seen as an agentive unit. There are substantial divergences, and even clashes, between the activities and aims of persons nominally of the same community, and these dissensions are evidence of substantial resistance to movements analogous to what Huntington terms "civilisational rallying" (1993, 39-41). Intra-communal antagonisms, such as those between religious officiants and a diversity of local practitioners, make evident the distinct interest groups involved in pushing, and resisting, rallying. The intervention of state agencies in cases where rallying is effected suggests that power, and state violence, rather than civilisational identification, is the driving force.

At the close of my "Nationalising and Denationalising the Sacred" I argued for more research on intercommunal interactions around holy sites as a means of promulgating "counter-images...allowing for and prompting the imagining of forms of community other than those alienated and isolate forms characteristic of the present" (Bowman 2012a, 219). Citing Walter Benjamin, I suggested that the images of intercommunal conviviality discussed above might be seen as "chips of Messianic time" (Benjamin 1969, 263)-moments of history, buried in the detritus of subsequent and surrounding events, that can be recuperated to show ways in which the present might be seen and experienced differently. Certainly, my investigation into the shaping of discourse by cultural conflict agents and agencies strengthens my sense of the importance of disseminating such studies so as to undermine simplistic arguments about 'clashing civilisations'. 


\section{The Social Contexts of Cohabitation and Antagonism}

When we discuss the social aspects of cohabitation and/or antagonism, it is important to delineate carefully what terrains are being occupied or contested. I would argue that here we are discussing places rather than spaces; places, in this context, are lived-in spaces or, in more academic terms, sites of inhabitance, while space denotes an area, of general or unlimited extent, indifferently providing the physical setting for such places. The Oxford English Dictionary notes that "place" is "a space that can be occupied... a particular spot or area inhabited or frequented by people; a city, a town, a village."13 Spaces are far more easily 'shared' than places, if sharing is the correct term to use when referring to coexisting in contiguous space. When suitably organised, entities can move past and around each other in space without effecting significant contact. Movement in shared places, however, entails negotiation, commensality, and, at times, conflict insofar as persons occupying place not only coexist with each other but are very much aware of the fact of that coexistence.

In Michael Sorkin's fascinating discussion of traffic in Giving Ground: The Politics of Propinquity we see, on the one hand, a modernist mode of organisation that channels persons and vehicles into non-intersecting pathways in order to give priority to unimpeded flow at the expense of relations between entities moving across the same terrain. On the other, Sorkin shows us a more traditional setting in which flow is impeded by repeated intersection and the necessary and mutually aware sharing of place:

Modern city planning is structured around an armature of...conflict avoidance. Elevated highways, pedestrian skyways, subway systems and other movement technologies clarify relations between classes of vehicles for the sake of efficient flow....The result is a city altogether different from the older Indian cities with their indigenous styles of motion....Typically Indian traffic is completely mixed up, a slowmoving mass of cows and pedicabs, motor-rickshaws, trucks and buses, camels and people on foot, the antithesis of "efficient" separation. Motion through this sluggish maelstrom does not proceed so much by absolute right as through a continuing process of local negotiation for the right of passage. (Sorkin 1999, 2)

In the latter case we are shown not only a space occupied by persons and entities but a place in which those inhabiting the terrain are linked together by what he terms "a primal rite of giving ground...the deference to one's neighbour that urban existence

13 Place, n.1. OED Online. March 2013. Oxford University Press (accessed 19 April 2013), see also Casey 1997, Casey 2002, and Massey 2005. 
daily demands" (ibid.). Here, rather than a skein of distinct and mutually disengaged pathways encompassed within a common space, we see a place inhabited by a diversity of persons and objects, shared through processes of mutual recognition and accommodation.

I would like to look further at this issue of "giving ground" in the particular context of shared holy places in the post-Ottoman Eastern Mediterranean ${ }^{14}$ so as to evaluate how such places are shared, what sorts of situations support that sharing, and what sorts of events or developments disrupt it. In a neighbourhood a multitude of different groups of people are tied together into a community by networks that variously engage them as individuals and groups. Shared practices of being in a neighbourhood enable both the recognition of the difference of others and the framing of that difference as something beneficial rather than problematic. Foregrounded here is the issue of whether we can see local communities, and the set of relations that constitute them, as forms of what Bourdieu called habitus. ${ }^{15}$ Bourdieu, in the rather dense terminology of his Logic of Practice, writes that

[t]he conditionings associated with a particular class of conditions of existence produce habitus, systems of durable, transposable dispositions, structured structures predisposed to function as structuring structures, that is, as principles which generate and organize practices and representations that can be objectively adapted to their outcomes without presupposing a conscious aiming at ends or an express mastery of the operations necessary to attain them. (Bourdieu [1980] $1990,53)$

Practices of interaction and negotiation of place experienced through living in a community imprint themselves in individuals as preconscious dispositions to act, and interpret, in the future in accordance with those earlier experiences. A person's dispositions are neither habits nor consciously applied rules but tacit knowledge, often embodied, learned through the "prestigious imitation...[of] actions which have succeeded and which he has seen successfully performed by people in whom he has confidence and who have authority over him" (Mauss [1935] 1979, 101). As Mauss, and Bourdieu after him, make clear, it is this process of internalising social practices (actions, interpretations, self-presentations) that imposes the social on the individual and that,

14 This terrain being that of my ethnographic field research between 1983 and the present.

15 The concept of habitus, itself a Latin translation of the Greek hexis, has a long genealogy stretching back nearly two-and-a-half millennia from Bourdieu's Outline of a Theory of Practice ([1972] 1977) and Logic of Practice ([1980] 1990) via Mauss' Les Techniques du Corps (1935) and Aquinas's Summa Theologica (la2ae, 49-54) to Aristotle's Nichomachean Ethics (1098b33). 
in effect, maps the neighbourhood-and its modes of incorporating and negotiating with internal difference-onto the selves who traverse it. "Giving ground," recognising the right of the other to be in the same place as oneself as well as committing to the rites of negotiating her presence, is a core element of the habitus of neighbourhood.

Two ethnographic studies, one on southern and the other on northern India, exemplify the ways neighbourhoods constituted by nominally distinct religious communities (communities that are elsewhere mutually antagonistic) are able to share place peacefully. The first text, Jackie Assayag's At the Confluence of Two RiversMuslims and Hindus in South India (2004), discusses what might be called a situational syncretism whereby Muslims and Hindus are able to celebrate at each other's religious festivals because, in the course of the communities living together for nearly a millennium, cultural elements that in the past might have been the exclusive properties of distinct communities have become part of an annual cycle of neighbourhood practices and thus, in effect, common property:

The religion of Mohammed insinuated itself very gradually in a Hindu environment already segmented by numerous castes, sects and local traditions. This mixture of discreet elements gave rise to many subtle and complex forms of acculturation caused by alteration, addition, superimposition and innovation, which vary from region to region. So by absorbing elements that were no longer either strictly Hindu or Muslim, but may have been the result of an earlier assimilation, these cultural forms allowed movement between systems of action and representation that seemed to be mutually exclusive. (Assayag 2004, 41)

Anna Bigelow's Sharing the Sacred: Practicing Pluralism in Muslim North India (2010) treats a seemingly more conscious process of intercommunal cohabitation in the town of Malerkotla, located in the Punjab, a far more conflicted region than Assayag's Karnataka. Bigelow notes that the town's cultivated tolerance might be seen as a response to Malerkotlan residents' horror of the sectarian cleansing that afflicted the Punjab during Partition (as well as of the violence of subsequent sectarian riots that have taken place in the region over the past few decades) leading to their recognition that "all religious groups are in some regard vulnerable...[making them] cognizant that their wellbeing depends on their positive relations with others" (Bigelow 2010, 10). However, she demonstrates fulsomely that overt intercommunalism is very much grounded on the town's "practice of everyday pluralism" (ibid., 217) and is a projection of "the vibrant community life in the streets and homes and shrines of a locale" (ibid., 223). In each case the 'cultural property' of one sectarian community is seen by members of adjacent communities as theirs as well, not because they wish to appropriate it 
but because, via a process of living with the 'owners' of the property and engaging with them in their quotidian lives, that property and the practices surrounding it have come to be seen as common. Whereas in some cases, such as those described by Assayag, sharing is unconscious for the most part because the traces of the ownership of significant elements of cultural property have been effaced by time, in others, as in Bigelow's Malerkotla, practices of mutual engagement in religious festivals and shrine worship are conscious moves to affirm community solidarities across sectarian borders. In both instances, however, sharing in religious celebrations and festivities is an extension of the habitus of a shared communal life. ${ }^{16}$

This is not, of course, to say that an identical 'script' of community response is instilled in all the community's members by their participation in a neighbourhood. While the term "disposition" suggests a tendency to interpret situations and act in response to them in certain ways familiar from past engagements with similar events, Bourdieu's work, like Mauss' before it, makes clear that there is "play" in the system of application allowing for accommodating specificities of context, of individuality, and of intention. A disposition is a proclivity rather than an imperative. Part of what accounts for the lability of persons' responses in communities in general and mixed communities in particular is the multitude of identities at play in any individual's experience of everyday life. The concept of "situational identities"17 enables us to recognise that a multitude of identity contexts exists in even the least complex of societies, and that when a community creates complexity to the extent of encompassing multiple ethnic and/or religious identities, the opportunities for a proliferation of identity strategies expands commensurately. At different moments of interaction within the community, different dispositions will be called to the fore. Thus in one instance you might be working with someone as a co-worker or in an employee-employer relation whereas, in another, sometimes even contiguous with the first, you might be called on to represent a family or a religious denomination. Each of these situations will call on distinct dispositions and may in fact call for enunciating those dispositions

16 See also the essays collected in Albera and Couroucli (2009 and 2012) and Bowman (2012).

17 "Situational identity" is a concept generally assumed to have been generated by, but not specifically used in, Erving Goffman's theory of the dramaturgical construction of social identity developed in The Presentation of Self in Everyday Life (1959). Max Gluckman had, however, elaborated the concept of "situational selection" in 1940 as individuals shaping their behaviour, in different social contexts, so as to conform to the values and practices of groups they there associate with: "the shifting membership of groups in different situations is the functioning of the structure, for an individual's membership of a particular group in a particular situation is determined by the motives and values influencing him in that situation. Individuals can thus live coherent lives by situational selection from a medley of contradictory values, ill-assorted beliefs, and varied interests and techniques" (Gluckman [1940] 1958, 26). 
in ways that improvise on previous enactments. What is important to stress is that none of these enacted identities are primary other than in situations-some of which will be elaborated below-in which the primacy of one of those identities is staged as more important than, and either subsuming or obviating, others. Recognition of the situatedness of identity articulations allows us to understand the ways numerous linkages can be made between diverse persons within a community, but also to see that certain events or developments might render previously amenable identities incommensurate and thus conflictual.

Nonetheless, investigation of the character of neighbourhood bonds resonates with Bigelow's $(2010,122)$ examination of Malerkotla's “daily work of community maintenance" and indicates that in most instances communities will seek to perpetuate communal cohesion. The concept of habitus makes clear that the degree to which people are who they are is a consequence of the appropriateness of their learned dispositions to settings the same as, or not unlike, those in which they internalized those dispositions. Radical reworkings of those settings-either through intercommunal conflict and separation or through migration or exile-threaten selfhood. There are, of course, circumstances that bring about the fragmentation of communities, but these often come about through external influences that, through direct action or the indirect impact of rumours or propaganda, create distrust and antagonism between elements of the community (compare again Tone Bringa's film We Are All Neighbours, 1993).

\section{Muslims and Christians in the Monastery of Sveti Bogoroditsa Prechista}

The powers people imagine as working in their world are social powers, conceived of in the image of their own experience of the world. Let me expand on this using an ethnographic encounter I had in Kicevo, Macedonia, in April 2006. I had been researching, with the help of Elizabeta Koneska of the National Museum of Macedonia, Muslim and Orthodox Christian uses of Sveti Bogoroditsa Prechista (the church of the Holy Mother of God Most Innocent) outside of Kicevo, itself a mixed Muslim and Christian town. In the course of examining the context of shared shrine practices, we interviewed the imam of the local Sunni mosque. Trained in the renowned Faculty of Islamic Studies in Sarajevo, he responded to our queries about Muslims attending the nearby Sveti Bogoroditsa monastery by asserting that he had never gone there and

never would. He nonetheless went on to explain that he would advise members of his congregation to go to the monastery for help with particular problems because 
the world of demons, like our world, is made up of Christians and Muslims. When someone is afflicted by a Muslim demon I can deal with the problem, but when someone is troubled by a Christian demon there is nothing I can do, so I send them to the church. (Interview, Kicevo, 30 April 2006)

What is of interest here, besides the concept of a mirror world of demons that replicates the demography of the lived world, is that-in this local context-the imam seems to see no incommensurability between this vision of the interaction of the demonic and the human worlds and that of a more Orthodox Sunni theology with its considerably stricter definition of domains, borders, and pollutions. ${ }^{18}$ Here, relations between the human and the demonic world are analogous to those occurring in the quotidian world of social interaction, and rites and obeisance made in the human world engage an economy of reciprocity with the demonic.

Just as the demonic world mirrors the intermixing of Muslim and Christian while maintaining the difference between the two, so, too, do movements within the ritual space of the church maintain that differentiation, even as Muslims "tap into" Christian rituals to ward off Christian demons. Sharing the space of the Sveti Bogoroditsa monastery's chapel does not entail a syncretic blending of identities, just as interacting on the streets and in the markets of Kicevo and its satellite villages does not effect an effacement of sectarian identities (compare Lockwood 1975, especially 195-211). Muslims within the walls of the church seem, on initial observation, to go through the same procedures of reverencing the saints and the sites of power as do Christians: they circulate through the church, they light candles in front of the icons (particularly those of the iconostasis, before which they lay gifts of clothing, towels, and sometimes money), and they proceed to the rear left of the church where, like the Christians, they pass a string of cross-inscribed beads over their bodies three times before crawling three times through a passageway beneath a pair of healing icons toward a well from which, in leaving, they take water to splash on their faces and carry home in bottles for healing (see Bowman 2010, 206-209, for a more detailed description). Closer observation reveals that this apparent mimicry is subtly but significantly differentiated. Muslims, holding back from Christian groups, introduce small but important differences of deportment. They do not cross themselves; they bow their heads before but do not kiss the icons; and, in praying, they silently mouth Muslim prayers while holding their hands close to their chests in front of them with their palms up. Muslims here 'work' an environment they know through the social world they share with their Christian neighbours and, in so doing, both engage in ritual acts that they have learned are

18 As I will show below, when the world of religious orthodoxy impinges upon local practices, it disrupts this intercommunalism, asserting property and propriety issues at the expense of sharing. 
efficacious from their neighbours (and their imam) and render appropriate obeisance to the powers resident in the place (the Virgin Mary, the saints, the Mother Superior, and the nuns). At the same time they refuse to violate their own identities by sacrilegiously adopting the signifiers of Christians as though they were their own. Here, in a religious setting, we have an interaction analogous to what Sorkin describes in the dense streets of Indian cities- "the continuing process of local negotiation for the right of passage". (Sorkin 1999, 2)

\section{Property and Propriety in Jerusalem's Church of the Holy Sepulchre}

The 'sharing' described above-a sharing extending into religious places the same modes of intercommunal mixing one sees in the everyday interactions of neighbours in the streets and workplaces of the region-differs substantially from the types of interactions one sees between strangers in sites they commonly revere, but not 'in common'. I will try to resolve this seeming contradiction between 'commonly revering' but not 'in common' through again referring to the "rigid designator" discussed by Kripke and Žižek (see also Vološinov [1929] 1973, 79-80). Generally, in a world of shared experience, "rigid designators" suffice to indicate objects and experiences common to those sharing that world, subsuming idiosyncrasies of personal experience or contextual application. However, where quotidian experience is not shared, identical signifiers may conjure up very different signifieds for the communities using them, and the differences may, in fact, prove to be incommensurabilities. In earlier examinations of the politics of Palestinian identity before and after Oslo (Bowman 1988, 1994), I wrote of the different ways the name "Palestine" signified both a future homeland and a reunified people to communities in different locales of exile, both outside and inside the borders of historic Palestine. So long as those populations remained isolated from each other, these disparities of understanding remained relatively unproblematic, but once Oslo effected a regathering of the Palestinians from the various sites of their dispersion serious conflicts erupted between groups over what Palestine should be, what Palestinians should be like, and who was, in fact, even truly Palestinian.

Something very similar happens at holy places with constituencies that gather from dispersed locales. Rather than neighbours sharing a sacred place, here we are talking of strangers coming together in the same space. The Holy Sepulchre in Jerusalem, known to Orthodox Christians as the Anastasis, lies at the centre of an extended web 
of narratives dealing with the death and resurrection of Jesus. ${ }^{19}$ When I carried out field research on Jerusalem pilgrimage in the early 1980s, the Holy Sepulchre, like other sites throughout the 'holy city' of Jerusalem, was visited by pilgrims from twenty-seven distinct Christian denominations (these, for the most part, further divided into distinct regional, national, and linguistic communities) as well as by a multitude of tourists, many from Christian backgrounds, but also many non-Christians. Five sects had places within the church-the Greek Orthodox, Catholics, and Armenians occupying the most territory, with the Coptic and Syrian Orthodox holding tiny chapels-while a sixth, the Ethiopians, held two external chapels and a rooftop. Despite this sectarian topography, the church was swept daily with pilgrims and tourists, the crowds flowing indiscriminately through the corridors and chapels. ${ }^{20}$ Such heterodoxy within a limited space could give rise to 'traffic problems' (pushing, expressions of hostility, and occasionally fights, usually between individuals not travelling in organised groups) but, for the most part, conflicts were avoided by what appeared to be spontaneous traffic management. This took place not through "local negotiation" but because groups moving through the church effectively 'enclaved' themselves into mobile units flowing past and alongside each other without either engagement or significant mutual recognition (see Bowman $2011,376-77)$. These groups, often made up of people coming from the same locale or brought together prior to the visit by an institution or a leader, constituted 'ingroups' able not only to insulate themselves from others but also, under the authority of spiritual or secular guides associated with the respective groups, to ensure that their perceptions of the sites and events they encountered confirmed and built upon their expectations. Such a mode of engaging with holy sites protected the integrity of the connection between rigid designators and the experiences they signified, while preventing the cognitive dissonance of others' readings of those shared designators from disrupting that alignment. ${ }^{21}$ While individuals within these groups shared with each other an experience of place, they simultaneously related to members of other groups like bodies in space, moving past and around them without effecting significant contact. Thus, while this site might nominally be termed a "shared site," the character of this interaction throws doubt on the applicability of the phrase "shared."

19 Despite the difference in name, the "place' of the crucifixion, tomb ("sepulchre"), and resurrection ("anastasis") of Jesus is established at the heart of New Testament biblical narratives, so that this nominal place can function as a rigid designator, even when ideas of its actual location can differ by several hundred meters (including the Anglican Garden Tomb, which lies outside the walls of the Old City).

20 The Greek Orthodox Katholicon was, however, normally closed to all but the Greek Orthodox.

21 These strategies were carried out throughout Holy Land pilgrimages and, one suspects, across other forms of organised travel-see Schmidt 1979. 
The relations described above rarely become conflictual because while those involved share the same space they rarely share the same place. For the majority of pilgrims travelling in mobile enclaves, the experience of holy places provides an intimate confirmation of the 'reality' of those sites and of the pilgrims' personal relations to that 'reality'; seeing the 'real' place, without being forced to acknowledge the dissonance of others' interpretations of its reality, provides a sense of spiritual ownership that visitors take back to their places of origin. ${ }^{22}$ "Strangers" do not need to literally own the place because they do not live there. For them it is enough to experience the place and possess the knowledge of its reality.

Relation to place is very different for the monks and priests who move through and live in the immediate vicinity of the church. Here we see institutionally shaped situations which resonate with the scenarios sketched, respectively, by Hassner and Hayden. These religious officiants see themselves as 'owning' the holy sites in a much more literal way, and their conception of property-and of propriety (an etymologically related term) - can but be conflictual when others who are not of the same community have similar claims on the sites and different conceptions of the modes of deportment proper to them. The Franciscan, Armenian, and Greek Orthodox brotherhoods that care for their respective chapels within the building ${ }^{23}$ are brought into daily, often conflictual, contact with others whose sense of the site's significance, the legitimacy of its possession, and the appropriateness of ritual activities carried out therein differ on numerous points. Although these men cohabit in the Holy Sepulchre and its neighbourhood, they do not share locale and dispositions in the ways set out earlier. Jeff Halper describes the monasteries of the Christian Quarter in the late Ottoman period as each enclosing radically different lifeworlds, redolent of the nations of the monks' origins (Greece, France, Armenia) rather than of Jerusalem (Halper 1984). In many ways, at least in terms of self-sufficiency and ideological closure, the situations in the monasteries have not changed much. These insulated habitus produce literal neighbours who are, in effect, strangers. Unlike pilgrims, who move past each other in the holy sites as migratory strangers, these hierophants are continuously forced to deal, in "their" holy places, with the presence of others who see those places as their own. For the monks and priests the holy sites in the 'shared' space of the Anastasis or Holy

22 Those whose experiences do not live up to their expectations, or in fact seem to refute them, may be impelled to deny that the sites are the "real" sites (either because the 'real' sites are elsewhere or because they have been effaced by time) or may be forced to question their previous assumptions and beliefs.

23 The Coptic, Syrian, and Ethiopian Orthodox, who possess chapels because of historic precedent, are small communities with little political or economic power, and their presence in the church is rarely challenged by the dominant religious communities (although they fight among themselves over the territories they do control; see Bowman 2011, 389-391). 
Sepulchre are organically connected to the 'pure' cultural spaces of the monasteries, and the presence of others in 'their' spaces, much less the attempt of those others to claim the spaces as 'their own', is anathema. Whereas in the above-cited situations of urban Indian traffic and Macedonian shrine sharing mutual investment in 'common ground' gives rise to generally amenable and decorous ritual processes of negotiation over co-presence, in the Holy Sepulchre quotidian encounters between representatives of the respective churches are only prevented from breaking into open violence by the regimen of the Status Quo, a system of spatial and temporal regulations initially imposed by the Ottoman state and currently maintained through fear of the open intercommunal warfare and state side-taking that its rejection would provoke. ${ }^{24}$

At the core of this conflict is not a simple issue of property ownership; actual property can-as the tenets of the Status Quo themselves assert-be shared, albeit through complex ritual regimes. Instead we are looking at issues more closely tied to propriety and, through that, to identity. Monks and priests associated with the Holy Sepulchre are able, when outside of domains demarcated as sacred, to relate to secular locals and even to members of other fraternities in non-conflictual-sometimes even amenable-ways (Tsourous 2017, 251-287). In contexts where religious identities are foregrounded, however, particularly in the choreographies of movements through the spaces of holy sites, they become representatives of their particular religious community or "defenders of the holy places," as members of the Greek Orthodox Brotherhood of the Holy Sepulchre called themselves in the wake of a fight with Armenian monks over contested space in Bethlehem's Church of the Nativity (fieldnotes, 31 December 1984). In these contexts, they and the places they 'protect' manifest the truth value of their church and its theology; their presence in the places and the rituals they carry out there are seen to 'suture' their dogma and their orthopraxy with Christian revelation. The presence of others carrying out their apostate rituals and asserting their authority in those places constitutes what Laclau and Mouffe term an "antagonism" (Laclau and Mouffe 1985, 93-148)-literally a radical denial of their own assertions of identity as the sole vehicles of the true church. ${ }^{25}$

It is in this context that property, and the propriety of liturgical demeanour therein, becomes an issue of overarching concern. Concern with overcoming the antagonism presented by the presence of other belief communities is what motivates

24 See Fisher-Ilan 2004 for one of many examples. Cohen 2008 and Bowman 2011, 2014 address different interpretations of how and why the Status Quo is maintained.

25 "In the case of antagonism...the presence of the 'Other' prevents me from being totally myself. ...(it is because a peasant cannot be a peasant that an antagonism exists with the landowner who is expelling him from his land). Insofar as there is antagonism, I cannot be a full presence for myself" (Laclau and Mouffe 1985, 125). 
the insistence of the various religious communities that they 'own' holy places and drives the demands of religious authorities worldwide that shrines and holy places be purged of heterodox practices and persons. The politics of the "rigid designator" is the insistence that there is but one signified for the signifier. While this may appear to take the shape of straightforward demands for sole possession and inhabitance of a holy place, beneath that demand is the assertion of the truth-value of a core identity and the insistence that no other representation can lay claim to the place where that identity manifests and celebrates itself. As a Greek monk told Nikos Kazantzakis when he visited the Anastasis in 1927:

This entire church belongs to us, the Orthodox. All the sacred shrines are ours. ...[W]e're going to throw the Armenians out....Whatever the Latins tell you is a lie. All their shrines are fakes. I hope to God the day comes when we can throw them out." (Kazantzakis 1973, 153)

\section{Sveti Nikola/Hadir Bābā: Simultaneity of Place}

The concept of 'property' functions in various ways in sites we refer to as 'shared'. In the case of Sveti Bogoroditsa Prechista, Muslims attending the monastery's church do not in any way dispute the Macedonian Orthodox Church's ownership of the site, visiting and using it with due deference to the nuns who live there. The Mother Superior and the majority of the nuns are in no way threatened by the presence of Muslims in the church, appreciating their generosity ("they give more than the Christians") and recognizing coexistence within the site as a welcome consequence of the long-term good relations of Muslims and Christians in the nearby town and surrounding countryside ${ }^{26}$ (see Bowman 2010, 209-212).

In another Macedonian site I have written on, Sveti Nikola, in Makedonski Brod, Sufi and Sunni Muslims praying in the church recognise the authority of the Orthodox caretakers, yet simultaneously associate the edifice and the tomb within it with the Bektashi saint Hadir Bābā. Relations between the Christian visitors from the town and the Muslim visitors from neighbouring settlements are cordial, and lubricated-as at Sveti Bogoroditsa-by the generosity of Muslims, whose copious gifts are auctioned off to support the town's main church. Intriguingly, in the case of Sveti Nikola/Hadir Bābā, mutual commitment by both communities to the continued sharing of the site

26 Although one university-trained novice, recently relocated to the monastery from Skopje, expressed hostility toward Muslim visitors, refusing to give them holy water and claiming they were planning to "steal" the church (Bowman 2010, 209). 
is manifest in the simultaneous display of Sufi and Christian iconography within the church although, as I describe in my study of the site, perceived imbalances of display are able to give rise to aggrievement and potential hostility (Bowman 2010, 203-206).

In both instances, as at the shrine of Haider Shaikh in Malerkotla described by Anna Bigelow, the local communities as well as the officiants at the religious sites commit themselves to maintaining, within the shrines, forms of intercommunal cooperation cognate with those taking place beyond their perimeters. Changes in that wider context of social relations, resulting in a breakdown of conviviality, can fracture that commitment, making way for one community to attempt to force the other from the shrine; such an expulsion would mirror that affected in the surrounding social world. In other instances, religious authorities, often backed by individuals of influence over local members of one or the other local religious community, may exploit frictions or fissures in the local community to push for the 'purification' of a shrine. Even in such instances, however, the perceived sanctity of a site may be retained by the general population so that not only members of the religious and ethnic communities banished from the site might return, covertly and sometimes overtly, but also, as relatively amicable intercommunal relations in the surrounding locale are re-established, the site may again begin to be shared (see Bowman 2012, 215-17).

Shrines such as the Anastasis or Holy Sepulchre are very different from those such as Sveti Nikola/Hadir Bābā and Sveti Bogoroditsa Prechista insofar as, rather than being perceived as property of the local community (in both the sense of belonging to the local milieu and being characteristic of that social formation), they are presented as standing outside of their immediate context, belonging instead to ideologically constituted communities that may originate, and even reside, at a substantial physical and cultural distance from their literal site. For pilgrims visiting such sites from afar, the holy places 'belong' to them in a spiritual or devotional sense. They ideologically imagine the place as a spiritual possession that, once witnessed, can be 'taken home' for meditation and validation, but their desire to literally possess the place rarely extends further than their wish to collect relics (oil, candles, carved olive wood crosses) that metonymically connect them with the place. For resident clergy, however, such holy places not only 'belong' to their sects in a spiritual sense but must literally belong to their churches, since possession of the site both confirms their core identities as guardians of the holy places and authorises and amplifies the sanctity of the site through their provision of appropriate liturgical practices (and their blockage of heterodox practices). Here, the presence of others not only presents an integral challenge to their identities but also desecrates the sanctity of that central site (see Hassner 2009). "Tolerance" is anything but toleration in this context as it is in effect no more than enforced cohabitation. 


\section{Strangers and Neighbours}

The distinction between 'space' and 'place' set out earlier is key to understanding the emergence of antagonism in shared sites. Space, as an encompassing container, is able to hold a number of entities without their having any relation aside from that of contiguity. Place, as a site of inhabitance, can contain differentiated bodies, but these, by sharing place, enter into relations with each other. Thus, on the one hand, pilgrim groups, converging on the same holy sites from different places of origin, are able to flow around and past each other, each pursuing their own realisations of their own envisionings of the significance of the sites they temporarily occupy. The 'place' each group inhabits is effectively rendered discontinuous with the 'places' of others, and interaction is kept minimal and impersonal. On the other hand, neighbours of different sectarian affiliations can meet in local holy places, engaging with each other through media of negotiation and mutual recognition analogous to those they use in their everyday interactions outside of holy ground. Here, each group simultaneously occupies the same place and must engage modes of mutual accommodation, rendering this coexistence as non-conflictual and as mutually beneficial as possible. In the instance of the Holy Sepulchre or Anastasis, a situation not unlike others worldwide in which religious powers work to present a site as a pure signifier of an exclusive identity that must be defended from the pollution of other forms of worship, ${ }^{27}$ two or more communities attempt to construct, and inhabit (literally and ritually), exclusive places at the same time in coterminous spaces. Such cohabitation is, in terms of the communities' respective discourses, an impossibility, and thus the presence of the other presents a literal antagonism that must either be overcome through expulsion or succumbed to by withdrawal; the structure of this particular relation is that of both Hassner's and Hayden's conceptions of the impossibility of sharing. The 'stand-off' that is the current status quo effected by the Status Quo is an ideological impossibility, and the Holy Sepulchre/Anastasis will remain a flashpoint, surrounded by the tinder of cadres of ideologically motivated monks, until either a discursive shift in the respective theologies replaces antagonism with fraternity or one group successfully expropriates and 'cleanses' the site.

In the post-Ottoman sphere, where conceptions of 'nationalist' identity increasingly impose themselves on domains where 'national' identities had served as markers of

27 A salient example is the 1992 destruction by Hindu activists of the Babri Mosque at Ayodhya in order to clear the site for the construction of the Sri Ram Janam Bhumi Temple commemorating the birthplace of Lord Rama (an avatar of Vishnu). 
nominal difference within mixed communities, ${ }^{28}$ places that had been shared-whether secular or sacred-are transformed into the exclusive properties of ethno-national groupings. Sharing, or even mixing, is there rendered contentious, and local events in which individuals with different allegiances clash come to be read more widely as indubitable signifiers of irresolvable antagonisms. Once such a discursive shift has taken place, and shared sites have been transformed into terrains on which struggles for possession take place, it becomes increasingly impossible to imagine contemporary cohabitation and sharing, and the image of coexistence fades into a utopian fantasy of a distant 'Ottoman' past (see Kamel 2019). Such a process of dissolution, to which Susan Woodward refers with reference to Former Yugoslavia as the "Balkan Tragedy" (Woodward 1995), appears to be the course onto which the clash of civilisations discourse is routing us, and at its terminus we, too, may sadly look back on the project of secular enlightenment as no more than a utopian fantasy.

As Benjamin knew, one cannot be so intellectually naïve as to believe that works such as his own and those cited in support of intercommunalism can change history; history-intellectual and political-is shaped by discourse, and discursive power relies on far more than words. Nonetheless, good scholarship can put into question the 'common sense' produced by those behind identitarian and clash of civilisations discourses, and offer alternative understandings resisting that ideology and the politics that inform it. Showing that difference can cohabit is important, but demonstrating how it does so, the socio-historical field in which it occurs, and what works against cohabitation, grounds and empowers a counter-discourse.

\section{Bibliography}

Albera, Dionigi, and Maria Couroucli, eds. 2009. Religions traversées; Lieux saints partagés entre chrétiens, musulmans et juifs en Mediterranée. Arles: Actes Sud.

- - - eds. 2012. Sharing Sacred Spaces in the Mediterranean: Christians, Muslims, and Jews at Shrines and Sanctuaries. Bloomington: Indiana University Press.

Albera, Dionigi, Manuel Penicaud and Isabelle Marquette, eds. 2015. Lieux Saints Partagés. Catalogue of MuCEM exhibition. Marseilles/Arles: MuCEM/Acts Sud.

Assayag, Jackie. 2004. At the Confluence of Two Rivers: Muslims and Hindus in South India. New Delhi: Manohar.

28 See Bowman 2015 as well as my discussion of the Titoist treatment of 'national' versus 'nationalist' identities in Bowman (2003, 229-30). 
Badiou, Alain. 200. The Century, translated by Alberto Toscano. Cambridge: Polity Press.

Barkan, Elazar, and Karen Barkey. 2014. Choreographies of Shared Sacred Sites. Religion, Politics and Conflict Resolution. New York: Columbia University Press.

Barkey, Karen. 2008. Empire of Difference. The Ottomans in Comparative Perspective. Cambridge: Cambridge University Press.

Baskar, Bojan. 2012. "Komšiluk and Taking Care of the Neighbor's Shrine in BosniaHerzegovina." In Albera and Couroucli 2012, 51-68.

Bastin, Rohan. 2012. "Saints, Sites and Religious Accommodation in Sri Lanka." In Bowman 2012c, 97-117.

Benjamin, Walter. (1950) 1969. "Theses on the Philosophy of History." In Illuminations, edited by Hannah Arendt, translated by Harry Zohn, 253-264. New York: Schocken.

Bigelow, Anna. 2003. "Places of Peace, Places of Power." Presentation at the Center for South Asian Studies. University of Virginia, Charlottesville, VA, January 31, 2003.

-_- 2010. Sharing the Sacred: Practicing Pluralism in Muslim North India. Oxford: Oxford University Press.

-_-. 2012. "Everybody's Baba: Making Space for the Other." In Bowman 2012c, 2543.

Bonney, Richard. 2008. False Prophets: The 'Clash of Civilizations' and the Global War on Terror. Oxford: Peter Lang.

Bourdieu, Pierre. (1972) 1977. Outline of a Theory of Practice, translated by Richard Nice. Cambridge: Cambridge University Press.

-_-. (1980) 1990. The Logic of Practice, translated by Richard Nice. London: Polity Press.

Bowman, Glenn. 1988. "Tales of the Lost Land: Palestinian Identity and the Formation of Nationalist Consciousness." New Formations 4: 31-52.

- - 1993 "Nationalizing the sacred: shrines and shifting identities in the Israelioccupied territories." Man: The Journal of the Royal Anthropological Institute XXVIII (3): 431-60.

- - . 2003. "Constitutive Violence and the Nationalist Imaginary: Antagonism and Defensive Solidarity in 'Palestine' and 'Former Yugoslavia'." Social Anthropology XI (3): 319-340.

- - . 2010. "Orthodox-Muslim Interactions at 'Mixed Shrines' in Macedonia." In Eastern Christians in Anthropological Perspective, edited by C. Hann and $\mathrm{H}$. Goltz, 195-219. Berkeley: University of California Press. 
- - . 2011. “'In Dubious Battle on the Plains of Heav'n': The Politics of Possession in Jerusalem's Holy Sepulchre." History and Anthropology XXII: 371-99.

- - . 2012a. "Nationalizing and Denationalizing the Sacred: Shrines and Shifting Identities in the Israeli-Occupied Territories." In Sacred Space in Israel and Palestine: Religion and Politics, edited by Yitzhak Reiter, Marshall Breger and Leonard Hammer, 195-227. London and New York: Routledge.

- - . 2012b. "Identification and Identity Formations around Shared Shrines in West Bank Palestine and Western Macedonia." In Albera and Couroucli 2012, 11-30.

- - , ed. 2012c. Sharing the Sacra. The Politics and Pragmatics of Intercommunal Relations around Holy Place. New York and Oxford: Berghahn.

- - . 2013a. "Popular Palestinian Practices around Holy Places and Those Who Oppose Them: An Historical Introduction." Religion Compass 7 (3): 69-78.

-_-. 2013b. "A Weeping on the Road to Bethlehem: Contestation over the Uses of Rachel's Tomb." Religion Compass 7 (3): 79-92.

- - 2013c. "Review of Anna Bigelow, Sharing the Sacred: Practicing Pluralism in Muslim North India." Comparative Studies in Society and History 55: 507-509.

- - - 2014. "The Politics of Ownership: State, Governance and the Status Quo in the Anastasis (Holy Sepulchre)." In Barkan and Barkey 2014, 202-240.

-_- 2016. "Grounds for Sharing-Occasions for Conflict: An Inquiry into the Social Foundations of Cohabitation and Antagonism." In Post-Ottoman Coexistence: Sharing Space in the Shadow of Conflict, edited by Rebecca Bryant, 258-275. New York and Oxford: Berghahn.

Bringa, Tone (anthropological advisor). 1993. "We Are All Neighbours.". Disappearing World. Directed by Debbie Christie. Granada Television.

Brubaker, Rogers. 2002 “Ethnicity Without Groups." Archives Européenes de Sociologie: European Journal of Sociology XLIII (2): 163-189.

-_- 2004. Ethnicity Without Groups. Cambridge: Harvard University Press.

Casey, Edward S. 1997. The Fate of Place: A Philosophical History. Berkeley: University of California Press.

-_- 2002. Representing Place: Landscape Painting and Maps. Minneapolis: University of Minnesota Press.

Cohen, Raymond. 2008. Saving the Holy Sepulchre: How Rival Christians Came Together to Rescue Their Holiest Shrine. New York: Oxford University Press.

Cormack, Margaret, ed. 2013. Muslims and Others in Sacred Space. Oxford: Oxford University Press.

Couroucli, Maria. 2009. "Saint Georges l'Anatolien, maître des frontièeres." In Albera and Couroucli 2009, 175-208 
- - . 2010. "Empire Dust: The Web of Relations in Saint George's Festival on Princes Island in Istanbul." In Eastern Christians in Anthropological Perspective, edited by Chris Hann and Hermann Goltz, 220-239. Berkeley: University of California Press.

Cuffel, Alexandra. 2003. “'Henceforth All Generations Will Call Me Blessed': Medieval Christian Tales of Non-Christian Marian Veneration." Mediterranean Studies XII, 37-59.

Driessen, Henk 2012. "A Jewish Muslim Shrine in North Morocco: Echoes of an Ambiguous Past." In Albera and Couroucli 2012, 141-147.

Fisher-Ilan, Allyn. 2004. "Dozens Hurt as Clerics Clash in Jerusalem Church." In AlertNet: Reuters Foundation.

Fowden, Elizabeth Key. 1999. The Barbarian Plain: Saint Sergius between Rome and Iran. (The Transformation of the Classical Heritage XXVIII). Berkeley: University of California Press.

-- - 2002. "Sharing Holy Places". Common Knowledge VIII (1): 124-146.

Gilsenan, Michael. 1982. Recognizing Islam. London: Croom Helm.

Gluckman, Max. (1940) 1958. The Analysis of a Social Situation in Modern Zululand. Rhodes Livingston Paper No. 28). Manchester: Manchester University Press.

Goffman, Erving. 1959. The Presentation of Self in Everyday Life. Garden City, NJ: Doubleday Anchor.

Halper, Jeff. 1984. "On the Way: The Transition of Jerusalem from a Ritual to a Colonial City (1800-1917)." Urban Anthropology XIII: 1-32.

Hassner, Ron. 2009. War on Sacred Grounds. Ithaca: Cornell University Press.

- - . 2010. "The Pessimist's Guide to Religious Coexistence." In Holy Places in the Israeli-Palestinian Conflict: Confrontation and Co-existence, edited by Yitzhak Reiter, Marshall Breger and Leonard Hammer, 145-157. London: Routledge.

Hayden, Robert. 2002. "Antagonistic Tolerance: Competitive Sharing of Religious Sites in South Asia and the Balkans." Current Anthropology 43 (2): 205-231.

- - . 2000. "Muslims as 'Others' in Serbian and Croatian Political Discourse." In Neighbors at War: Anthropological Perspectives on Yugoslav Ethnicity, Culture and History, edited by Joel Halpern and David Kideckel, 116-124. Philadelphia: University of Pennsylvania Press.

- - . 2015. "Intersecting Religioscapes in Post-Ottoman Spaces: Trajectories of Change, Competition and Sharing of Religious Spaces." In Shared Spaces and their Dissolution: Practices of Coexistence in Cyprus and Elsewhere, edited by Rebecca Bryant, 59-85. New York and Oxford: Berghahn. 
Hayden, Robert, Tuğba Tanyeri-Erdemir, Timothy D. Walker, Aykan Erdemir, Devika Rangachari, Manuel Aguilar-Moreno, Enrique López-Hurtado, and Milica BakićHayden. 2016. Antagonistic Tolerance: Competitive Sharing of Religious Sites and Spaces. London and New York: Routledge.

Henig, David. 2012 “'Knocking on my neighbour's door': On metamorphoses of sociality in rural Bosnia." Critique of Anthropology 32 (1): 3-19.

Huntington, Samuel. 1993 “The Clash of Civilizations?" Foreign Affairs LXXII (3): 22-49.

- - - 1996. The Clash of Civilizations and the Remaking of World Order. New York: Simon and Schuster.

Kamel, Lorenzo. 2019. The Middle East from Empire to Sealed Identities. Edinburgh: Edinburgh University Press.

Kaplan, Robert 1993. Balkan Ghosts: A Journey through History. New York: St. Martin's Press.

Kazantzakis, Nikos. 1973. Journeying: Travels in Italy, Egypt, Sinai, Jerusalem and Cyprus, translated by Themi Vasils and Theodora Vasils. Boston: Little, Brown and Company.

Koneska, Elizabeta. 2013. "Shared Shrines in Macedonia". In Forum Folkloristika 2. https://eefc.org/post-folklorista/shared-shrines-in-macedonia/.

Kripke, Saul. 1980. Naming and Necessity. Oxford: Blackwell.

Laclau, Ernesto, and Chantal Mouffe. 1985. Hegemony and Socialist Strategy: Towards a Radical Democratic Politics, translated by Winston Moore and Paul Cammack. London: Verso.

Lewis, Bernard. 1990. "The Roots of Muslim Rage." The Atlantic Monthly CCLXVI (3): 47-60.

Lockwood, William. 1975. European Moslems: Economy and Ethnicity in Western Bosnia. (Studies in Anthropology). New York: Academic Press.

Lubańska, Magdalena. 2013 “Muslim Pilgrims at the Orthodox Christian Monastery in Hadzhidimovo: Studies on Religious Anti-syncretism in the Western Rhodopes, Bulgaria." Anthropological Journal of European Cultures 22 (2): 91-110.

- - - 2015. Muslims and Christians in the Bulgarian Rhodopes. Studies on Religious (Anti)Syncretism. Berlin: De Gruyter.

Massey, Doreen. 2005. For Space. London: Sage Publications.

Mauss, Marcel. 1935. "Les Techniques du corps." Journal de psychologie normale et pathologique XXXII: 271-93.

_-_. (1935) 1979. "Body Techniques." In Sociology and Psychology: Essays, trans. Ben Brewster, 95-123. London: Routledge and Kegan Paul.

Mayer, Jane. 2016a. Dark Money. London: Scribe. 
- - . 2016b. "How Right-Wing Billionaires Infiltrated Higher Education." In The Chronicle of Higher Education. February 12, 2016. http://www.chronicle.com/ article/How-Right-Wing-Billionaires-/235286.

Medvetz, Thomas. 2012. Think Tanks in America. Chicago: University of Chicago Press. Meri, Josef W. 1999. "Aspects of Baraka (Blessings) and Ritual Devotion Among Medieval Muslims and Jews." Medieval Encounters 5: 46-69.

- - . 2002. The Cult of Saints Among Muslims and Jews in Medieval Syria. (Oxford Oriental Monographs). Oxford: Oxford University Press.

Ratner, Lizzy. 2005. "Olin Foundation, Right Wing Tank, Snuffing Itself ." In The Observer. May 9, 2005 http://observer.com/2005/05/olin-foundation-rightwingtank-snuffing-itself/.

Schmidt, Catherine. 1979. "The Guided Tour: Insulated Adventure." Urban Life 7: 44168.

Short, Thomas. 2007. Peirce's Theory of Signs. Cambridge: Cambridge University Press.

Sorabji, Cornelia. 2008. "Bosnian neighbourhoods revisited: tolerance, commitment and komšiluk in Sarajevo." In On the Margins of Religion, edited by Francis Pine and Joao Pina-Cabral, 97-112. Oxford: Berghahn.

Sorkin, Michael. 1999. "Introduction: Traffic in Democracy." In Giving Ground: The Politics of Propinquity, edited by Joan Copjec and Michael Sorkin, 1-15. London: Verso.

Spring, Joel. 2010. Political Agendas for Education. (Sociocultural, Politics and Historical Studies in Education). New York and Abingdon: Routledge.

Tsourous, Georgios. 2017. "Boundaries and Borders: Choreographies among the Rum Orthodox of Old City Jerusalem." PhD diss., University of Kent.

Valtchinova, Galia. 2012. "The Mount of a Cross. Sharing and Contesting Barriers on a Balkan Pilgrimage Site." In Albera and Coucoucli 2012, 69-93.

Vološinov, Valentin N. (1929) 1973. Marxism and the Philosophy of Language, trans. Ladislav Matejka and I. R. Titunik. Cambridge, Massachusetts: Harvard University Press.

Woodward, Susan. 1995. Balkan Tragedy: Chaos and Dissolution After the Cold War. Washington, D.C.: The Brookings Institute

Wright, Robin. 1992. "Islam, Democracy and the West." Foreign Affairs 71 (3): 131-145. Žižek, Slavoj. 1989. The Sublime Object of Ideology. (Phronesis). London: Verso. 


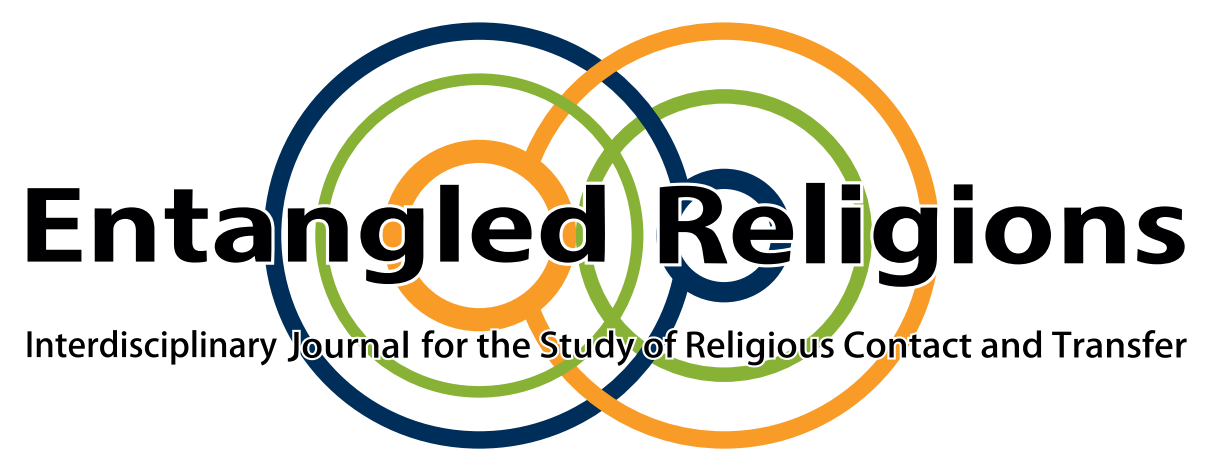

\section{Digressions on Polytropy: An Exploration of Religious Eclecticism in Eurasia}

DIONIGI ALBERA

National Center for Scientific Research, Aix-Marseille University, France

This contribution to Entangled Religions is published under the Creative Commons Attribution 4.0 International Public License (CC BY 4.0 International). The license can be accessed at https://creativecommons.org/licenses/by/4.0/legalcode.

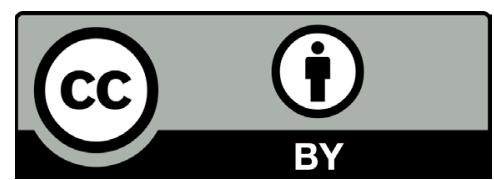

Entangled Religions 9 (2019) http://doi.org/10.13154/er.v9.2019.139-164
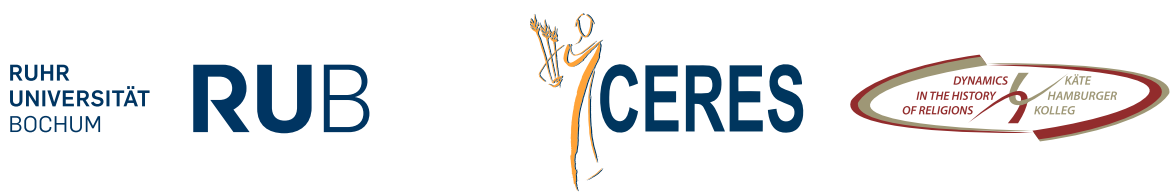

SPONSORED BY THE 


\title{
Digressions on Polytropy: An Exploration of Religious Eclecticism in Eurasia
}

\author{
DIONIGI ALBERA \\ CNRS-Aix-Marseille University
}

\begin{abstract}
The anthropologist Michael Carrithers introduced the notion of polytropy in the field of the study of religion, proposing that this notion (deriving from the Greek poly, 'many', and tropos, 'turning') may account for the eclecticism and fluidity of South Asian religious life. The exploration effectuated in the article suggests that the notion of polytropy could offer a promising tool for capturing some important features of religiosity in other Asiatic contexts, too, as well as in the Mediterranean. Polytropic trends appear in different religious contexts, from the fuzzy Chinese situation, where religious affiliations are very limited in their scope and relevance, to the South Asian contexts, in which religious orientations coalesce around the multivocal concept of dharma, to the tightly structured Abrahamic religions in the Mediterranean with their strong confessionalism. Polytropy is associated with a practical mode of religiosity and is linked to a particular conception of believing in which the believer tends to multiply the transactions with different supra-mundane partners. This orientation is distinct from religious styles that are based on a discursive and scriptural approach and/or on the cultivation of oneself, which often display a tendency towards unity, coherence and continuity. This permits identifying an opposite pole with respect to polytropy, which I define as monotropy.
\end{abstract}

KEY WORDS polytropy; monotropy; ambiguity; religious contact; syncretism; cosmopolitanism; Asia; Mediterranean

\section{Introduction}

During the last years, there has been a growing academic interest in the study of multireligious attendance at the same sacred places. This phenomenon has been studied in various geographical contexts and through multiple lenses, for example paying attention to the relations between groups or to the interference of social solidarities and cultural connivances at a local scale, across religious divides. This common attendance also offers a fruitful field to investigate the dimension of religious action and its articulation of beliefs and values. From this point of view, the behaviour recorded at shared shrines seems to challenge several assumptions concerning congruence in individual religiosity. 
The issue of religious congruence has been authoritatively raised, on a general level, by Mark Chaves. In his presidential address delivered at the 2009 annual meeting of the Society for the Scientific Study of Religion, he drew the attention to a pervasive problem in the scientific study of religion that he defined as the "religious congruence fallacy". Chaves gives a precise definition of three main related senses of the "religious congruence" that are currently postulated in the study of religion:

(1) individuals' religious ideas constitute a tight, logically connected, integrated network of internally consistent beliefs and values; (2) religious and other practices and actions follow directly from those beliefs and values; and (3) the religious beliefs and values that individuals express in certain, mainly religious, contexts are consistently held and chronically accessible across contexts, situations, and life domains. (Chaves 2010, 2)

In other words, conventional thinking presumes that religious congruence is common, that one can expect a consistency both among individuals' beliefs and attitudes, and between their ideas and behaviour. Moreover, these ideas and dispositions are thought of as stable and with a chronological continuity across contexts and circumstances. Chaves suggests that this line of thinking is wrong, since a great amount of research in several domains (anthropology, psychology, sociology) has shown that this kind of congruence is, on the contrary, rare. Nevertheless, the assumption of congruence is still extremely widespread. It is a sort of reflex that goes against the results of scientific research. This is precisely the "religious congruence fallacy" pointed out by Chaves.

The literature on shared sacred places suggests some possible ways to expand Chaves' argument, which is mainly concerned with contradictions within a particular religious system. As a whole, these findings challenge conventional wisdom, which frequently postulates that individuals inscribed in a religious culture comply only with the individual and collective, private and public rites that are prescribed in order to substantiate a particular creed. Furthermore, they also defy widespread viewpoints concerning membership in one religion that imply, for example, (1) that individuals belong to a religion, (2) that they belong to only one religion, and (3) that their membership is stable during the time. In this article, I will propose some preliminary considerations with the aim of enlarging the scope of the discussion of religious congruence. I will concentrate the attention on the frontiers of religious systems, and this by following the thread of the notion of polytropy, which expresses the propensity to worship a variety of holy figures without restraining the choice to a particular religious tradition. I will pursue two main objectives: on the one hand, expanding the 
comparative perspective across Eurasia; on the other hand, positioning the issue of the sharing of sacred sites in the general framework of a discussion of religious action.

\section{From India to China}

The British anthropologist Michael Carrithers has introduced the notion of polytropy in the field of the study of religion. In a seminal article, he proposed that this notion (deriving from the Greek poly, 'many', and tropos, 'turning') may account for the eclecticism and fluidity of South Asian religious life "in which people turn toward many sources for their spiritual sustenance, hope, relief, or defence", without confining themselves to a particular religious tradition (Carrithers 2000,834). The ethnographic focus of the article is restricted to the case of the Digambar Jains in India, but as the author makes clear, the notion of polytropy fits with religious practices that are present in a vast area of South Asia, from the Himalayas to Sri Lanka, characterized by the pervasiveness of religious pluralism (ibid., 832). Carrithers refers to scholarly works such as Susan Bayly's (1989), Paul Dundas' (1992) and David Gellner's (1992), which have illustrated the fluidity and the eclecticism of Indic religious life in different regional settings. Living in a religiously plural situation, people develop a reverential attitude towards holy figures related to different religious traditions, and often manifest devotion towards them. As a matter of fact, there is a huge literature that shows this propensity, both before and after the publication of Carrithers' article (see for example Assayag 1995; Assayag and Tarabout 1997; Bellamy 2011; Bigelow 2010; Boivin 2005; Mosse 1994; Sébastia 2002; 2007; Sikand 2002; 2003; Younger 1992).

Let us examine how Carrithers defines the range of meanings covered by the term polytropy. First, for him polytropy denotes that

the consumers of religion actively turn to persons, not to impersonal or natural powers. Such persons may be straightforwardly divine, such as gods and goddesses, or living divine persons such as gurus, or even living persons such as priests or mediums who may intercede with a divine person on your behalf. (Carrithers 2000, 834)

This diversity also reverberates in the modalities of the relationship to these entities. As a consequence, the second aspect of polytropy is that it covers many forms of religious relationship, "from the occasional request for relief or a favour from a distant god, through the god visited occasionally or on festival occasions, to the god whom one visits daily" (ibid., 835). Third, for Carrithers polytropy has a particular Indic quality and 
is strictly associated with puja, the typical act of devotion and respect, often including a material offering which is reserved to a divinity (and its images), but also, on a purely human plan, to a highly honoured guest. Such an association with puja highlights the fourth feature of polytropy, namely the fact that it "is a dynamic process". Puja tends "to be applied widely and promiscuously to objects, persons and relationships". Moreover, "the thought which goes with puja is not scholastic or finely discriminating, but practical and interactive, arising from deeply felt corporeal attitudes"(ibid., 835836).

On the basis of an analysis of some Jain examples, Carrithers shows that puja has an exuberant character: a great creative effort has resulted in elaboration and complication in the practices, which may often attain a rather baroque complexity. The main aim of the worshiper, when he or she addresses a holy person through an elaborate series of performances and offerings, is to obtain worldly well-being in exchange, to be blessed with good fortune (ibid., 846-47). This material orientation of the devotion (both in its aim and in its enactment) has provoked the criticism of the austere purists, who nevertheless only represent a tiny, cultivated minority within Jainism. As a whole, Carrithers suggests that the notion of polytropy may be seen "as the label of a pervasive social process, a sort of religious Brownian motion or better, vigorous vegetative growth" (ibid., 836), which captures what the title of the article defines as "the natural condition of spiritual cosmopolitanism in India."

The pertinence of the notion of polytropy has been recognised in some works consecrated to the study of religion in South Asia (Gellner 2005; Frøystad 2012; Tuladhar-Douglas 201212). Moreover, David Gellner $(2005,756)$ has suggested that this "felicitous term" may be used for other areas, since polytropic religious situations, "far from being unique to South Asia, are common in Asia as a whole". This direction has been followed by Adam Chau (2011; 2012), who has retained the notion of polytropy to describe the religiosity that characterised late imperial China, where the majority of the population lacked confessional distinctions. Here, commoners did not define themselves as Daoists, Buddhists, or Confucians. A collective religious identity of this type only developed among small groups of specialists and virtuosi who relied on canonical texts and practiced self-cultivation. Also at this level, which only concerned very restricted

1 Studying the Newars in Nepal, Tuladhar-Douglas (2012) raises some important issues. He puts polytropy in relation to what he defines as polynomy, so designating the multivocality of shrine images. Moreover, he stresses the local character of polytropy and the centrality of the dimension of place: "For Newars polytropies are local, and it is possibly because individuals are grounded in the ritual construction of a shared locality that each participant feels a profound sense of place" $(2012,72)$. His fieldwork in the town of Pharping shows that exclusivist behaviour, asserting a single religious identity, "tends to be disavowed or resisted by those who practice polytropic inclusivism" $(2012,73)$. 
minorities, the traditions were not hermetically closed and self-contained. A reciprocal attraction to texts and philosophical reflections generated "frequent and serious trafficking of people and ideas between these three Great Traditions" (Chau 2012, 80). Moreover, even among elites, identities were not comparable to the confessional identities in monotheistic religions but were more akin to professional identities: "So a Confucian scholar-ritualist could learn to become a Daoist priest in a process culminating in the Daoist ordination ritual, which was more like additional professional accreditation than a statement of religious conversion" (Chau 2011, 557). Among the majority of the population, which was without any religious affiliation, the circulation of people and symbols was extremely widespread and the persons resorted easily to whichever ritual specialist or deities were available to them. As a consequence, "in their everyday life the Chinese are not dissimilar to the paradigmatically polytropic Indians characterized by Carrithers". Their domestic altars hosted Daoist, Buddhist, and other kinds of deities alongside the tablets for their ancestors pertaining to a Confucian tradition. Like their South Asian counterparts, Chinese approached deities or religious specialists in an opportunistic manner, without worrying about their association with this or that religious tradition, in order to receive supernatural help and assistance for a vast array of material issues (Chau 2012, 80). Thus, the majority of Chinese were involved in an "efficacy-based religiosity" in which what mattered above all was the effectiveness of rituals.

In particular, Chau concentrates his analysis on the example of Chinese funerals. In China, either Daoist priests or Buddhist monks were able to perform the burial rituals. People of the lower and middle classes could engage either the one or the other kind of monks, according to their availability and to local traditions. In contrast, rich families hired several groups of religious specialists in order to accrue spiritual benefit for the deceased and to affirm the social prestige of the household. A case that Chau examined in detail shows that the funeral choreography of a Chinese general, who died in Beijing in 1939, included substantial groups of Buddhist monks, Buddhist nuns, Daoist priests, and Tibetan Buddhist lamas, not to mention several lay sectarian practitioners. All these groups operated in a complex ritual sequence spread over at least a year, which implied the contemporaneous involvement of more than one hundred ritualists at different moments (Chau 2012, 87-88). To qualify this form of mixing, in which groups of specialists belonging to different religious traditions intervene in the same ritual event, Chau $(2011,558)$ proposes to modify the notion of polytropy as defined by Carrithers, speaking instead of "ritual polytropy". For him, the notion of "ritual polytropy" is the key for grasping the central nature of Chinese religiosity.

If Chau $(2012,89)$ underlines that "the Chinese lived in a Confucian-BuddhistDaoist polytropy," he also emphasizes "a significant qualitative difference between 
Chinese 'ritual polytropy' and the traditional 'religious polytropies' found in India and other South Asian countries such as Nepal." In South Asia, polytropy was associated with a situation in which people possessed "relatively unambiguous religiocultural identities." Thus, if "a Hindu might do puja to all figures of authority and deities of any tradition", nevertheless "he was still a Hindu." Analogously, "a Newar Buddhist might fully participate in a Hindu festival but he was still a Buddhist" (ibid.). On the contrary, in China it was only "the efficacy of the rituals (and the ritualists) that mattered, not the religious identity of the people," which was in fact almost completely indiscernible (ibid.). In this way, Chau draws a contrast between an "efficacy-based religiosity", typical of China, and a dharma-based (or path-based) religiosity that dominated in South Asia. Here, "being a Hindu, a Jain or a Buddhist was following a path, embodied in the teaching (dharma)", and this would concern all the social strata, without being confined to the narrow circles of the specialists and the virtuosi. Consequently, a dharma-based religiosity would correspond to a form of confessionality, even if Chau admits that in these contexts the latter was less strong than in the Abrahamic religions (ibid.).

As a whole, Chau's contribution is extremely stimulating and opens challenging comparative perspectives. Yet certain points of his argument arouses some perplexity. First, his analysis of Chinese ritual polytropy seems to rely almost uniquely on the scrutiny of funerals (and above all of rich people's funerals). This is undoubtedly a significant entry point to understand Chinese attitudes in religious matters, but it cannot be considered as representative of all forms of piety. On the whole, the miscellaneous hiring of a heterogeneous set of religious specialists seems confined to fairly rare events, while in their common polytropic activities, the great majority of Chinese interacted separately with the representatives of different religious traditions, like their South Asians counterparts were accustomed to doing.

Second, the opposition between Chinese and South Asian religious propensities seems to be based on too rigid a vision of religious identities of the latter. Undoubtedly, the fuzziness of religious identities was more pronounced in China, but decades of historical and ethnographic work on the Indian subcontinent suggest a more nuanced image of religiosity, marked by fluid religious categories and the lack of mutually exclusive religious groups. It seems rather problematic to put this variegated situation under the umbrella of an immemorial dharma-based religiosity. The contemporary situation, where clearly defined identities prevail, is the result of a complex history and cannot be projected indiscriminately on the past, even on a recent past. For instance, what is now called "Hinduism" is, in many respects, the result of the joint efforts of the British colonial administration, local Brahmins, Christian missionaries, European Orientalists and local reformists. A conglomerate of castes, cults, practices and beliefs 
was thus subsumed under a unified religious community through a definition largely "reinvented" on the basis of the learned tradition of the Vedas, collated by Indian scholars, legitimized by the British administrative apparatus, canonized by European scholarship, and reinforced by the missionary activity of reformist movements (Assayag 1997, 32-42). Commenting on the argument advanced by David Gellner (2005), who suggested that the idea of a unique and exclusive religious attachment was propelled quite recently in Nepal by Western influence, particularly through the introduction of censuses unambiguously recording people's religious identities, Chau (2012, 90-91) observes that this exclusive religious belonging "is not entirely modernist or Western in origin." For him, a dharma-based religiosity has paved the way for modernist schemes of religious categories, and "there has been 'elective affinity' between the traditional dharma-based religiosity found in South Asia and modernist confessional religious identities." This vision is difficult to reconcile with recent findings which show that Nepalese migrants to the United Kingdom have a resilient propensity to affirm multiple religious identities. A survey carried out in 2010 shows that more than 25\% of the interviewees, when asked what their religion (dharma) was, declared multiple affiliations: Hinduist and Buddhist, Kirat and Induist, Kirat and Bouddhist (Gellner and Hausner 2013; see also Hausner and Gellner 2012).

Third, and more crucially, it seems difficult to admit that an "efficacy-based religiosity" could be considered as uniquely Chinese. As a matter of fact, many descriptions point to the dimension of efficacy as a crucial "motor" of polytropic forms of devotion in other regions as well, namely in South Asia, where the notion of dharma is far from having a monopolistic influence on concrete practices of people. It is doubtful that the idea of an "efficacy-based religiosity" could be considered as a label exclusively for Chinese religiosity. Indeed, this orientation seems to be a widespread tendency present in different religious traditions.

\section{Is Polytropy Compatible with a Monotheistic Environment?}

The exploration effectuated so far suggests that the notion of polytropy could offer a promising tool for capturing some important features of religiosity in Asia. As Gellner (2005) has proposed, this notion could, for instance, also be useful in describing Japanese religiosity, which has long been characterised by a fuzziness of religious identities largely comparable to that observed in China. From the introduction of Buddhism in the sixth century until the second half of the nineteenth century, there was a close association between Shinto and Buddhist practices, sites, and beliefs in 
Japan. For centuries, the faithful went to the same shrines to worship both kami and bodhisattvas. These pilgrimages were marked by a confessional blur, making it difficult to attribute them to either tradition (Thal, 2005). It was only after the Meiji Restoration (1868), in fact, that Buddhism and Shinto were identified as separate religions (Grapard 1984; Sekimori 2005). Nevertheless, this process has been far from producing univocal religious identities and practices. For instance, Ian Reader (1991) has offered a vivid portrayal of religion in late twentieth-century Japan, showing that Shinto and Buddhism maintain a complementary nature. A vast bulk of evidence (participant observation, interviews, statistics) makes it clear that the two traditions "are not at all exclusive: praying to one does not prevent one from praying to the other." More generally, "there is very little differentiation, especially at explicit levels of religious action, between apparently separate religious traditions in Japan, with Shinto and Buddhism in particular interpenetrating to form an amalgam in the eyes of the general populace" (Reader 1991, 2).

Scholars like Carrithers, Chau, and Gellner seem to grant polytropy a somewhat cultural character. For them, this term would capture a basic tonality of Asian religiosity (even if they do not agree entirely on the relative strength of this tendency in the different regions of this continent). Polytropic orientations seem more or less intensely dissimilar from, and irreducible to, the logic of modernist schemes of religious categories and modernist confessional religious identities, which have been exported quite recently from the West to Asia, as well as the notion itself of "religion". These categories and these notions of religious identity are embedded in the history of the monotheistic religions. Therefore, it becomes relevant to test the possibility of using the notion of polytropy as an analytic tool in the latter context.

A number of works concerning several Asian regions show that the followers of monotheistic faiths, be they Christians or Muslims, are frequently implied in polytropic manifestations of worship (Assayag 1995; Assayag and Tarabout 1997; Bellamy 2011; Bigelow 2010; Boivin 2005; Mosse 1994; Sébastia 2002; 2007; Sikand 2002; 2003; Younger 1992). Yet in a culturalist vein, it would be possible to argue that this phenomenon could be the result of the acclimatization of monotheistic religiosity in the Asian context, dominated by a tendency towards fluid religious practices and identities. Thus, in order to assess more cogently if polytropy can be conceived of only as a cultural orientation typical of Asia or as a more general tendency, it is significant to test its presence in the Mediterranean region, where the religious landscape has been uniformly characterized by the exclusive (and exclusivist) presence of monotheistic religions for many centuries. 
Looking at the vast body of literature that has explored the sharing of sacred sites in different sectors of the Mediterranean region ${ }^{2}$ in the last years, it seems that even here it is possible to isolate polytropic forms of religiosity, generally linked to an efficacy-based orientation of religious practices. Moreover, these manifestations of devotion across religious borders are far from exceptional in this context: these phenomena are substantial and persist long-term everywhere that different religious groups have lived in close proximity. In other words, Mediterranean religious pluralism seems to produce effects comparable to those observed in Asia.

Several clues suggest that in monotheistic contexts, exclusivism is not a predictable, "natural" datum, simply stemming from the reverberation of an uncompromising theological core on the behaviour of the faithful, but rather the result, often partial and provisional, of the action of political powers and religious specialists aiming to establish the purity of the cult and to consolidate confessional borders. For instance, at the beginning of the Christian era, the separation between "the church" and "the synagogue" was a process that spanned several centuries, during which a broad spectrum of intermediate groups survived (Kinzing 1991). This sometimes led to a certain confessional fuzziness. Thus, faithful who were supposedly affiliated to different creeds could share, on certain occasions, the same shrines and perform similar acts of devotion. The homilies of John Chrysostom reveal phenomena of this type in the religious life of late fourth-century Antioch. From the pulpit, the saint attacks a whole series of "Judaizing" behaviours of Christians living in the city. He reprimands Christians for celebrating Jewish holidays, fasting along with Jews, and attending Jewish shrines and synagogues (to seek healing through incubation, to practice ritual oaths) (Vinson 1994; Shepardson 2007). In the fifth century, Sozomen relates another interesting example of religious mixing, located in the surroundings of Hebron, by the Oak of Mambre, a central place in biblical topography, where three mysterious figures would have visited Abraham as he was sitting at the entrance of his tent during the hottest hour of the day. Every year, a panegyris commemorating this episode attracted Christians, Jews, and Pagans in a mixture of rituals and interpretations (Sozomène 1983, 2: 246-247).

The following centuries witnessed the consolidation of the domination of monotheistic tendencies and the growth of a third great monotheistic movement: Islam. Even in this case, early phenomena of crossing may be considered as polytropic behaviours. Several sources, including especially the monasteries' books compiled by Muslims, demonstrate, for instance, the importance of Christian monasteries in

2 It is impossible to provide a complete list of the numerous articles that have explored these aspects here. Among the books that are concerned with this topic, see Albera and Couroucli (2012); Barkan and Barkey (2014); Ben Ami (1990); Bowman (2012); Chiffoleau and Madeuf (2005); Cormack (2013); Hayden and alii (2016); Valtchinova 2010. 
Abbasid society-in Iraq, Egypt, and Syria-and reveal a large attendance by Muslims in these places. The reasons for these visits were multiple and may also have had a devotional character. The annual festival of the monasteries attracted many Muslim visitors, who not only participated in the festivities but also mixed in the religious celebrations. Muslims worshipped icons (especially those of the Virgin), relics, and other religious objects. The monasteries' books also provided guidance on the thaumaturgic specialties of each shrine. Like Christians, Muslims went there to solve their problems and make vows. Some monasteries were known for their therapeutic properties. For instance, people bathed in sources to cure skin diseases, or took a handful of earth which ensured the protection of the house from scorpions (Landron 1994, 31-35; Kilpatrick 2003).

These border crossings are not confined to the early phases of Christianity or Islam. Several manifestations of the same nature regularly occurred when these religions were much more established. A great variety of sources-travel books, hagiographies, polemical writings, and, most recently, studies of folklore, history, and ethnographytestify to a myriad of exchanges in religious behaviour from the Middle Ages to the present day. An important contribution to the understanding of these interreligious phenomena comes from research on the relations between Christians and Muslims in the Ottoman Empire carried out in the first decades of the twentieth century by the English scholar Fredrick Hasluck (2000). The historical and contemporary sources studied by this author showed that relations between religious groups were often symbiotic. Both Christians and Muslims were ready to address their requests to a sanctuary administered by another religion, if the latter had a reputation for efficacy (ibid., 100)-to the point that, according to Hasluck (2000 97), this crossed frequentation constituted a "common phenomenon" and was almost banal. Although the focus of his work concerned the interplay between Christians and Muslims, Hasluck also documented several examples in which interreligious attendance of the same shrine concerned the Jews.

Over the centuries, the Mediterranean landscape has been punctuated by thousands of sanctuaries marked, often for long periods, by interpenetration between different traditions. Most of the shared attendance associated Christians and Muslims in places belonging to one or the other religion. This is not surprising, given the greater quantitative importance of these two religions. Some sites attract the faithful of the three monotheistic religions. On the other hand, depending on places and times, several forms of common visitation concern only Jews and Muslims. Judeo-Muslim cults were notably spread in the Maghreb. These phenomena were particularly studied in relation to Morocco, where a panoply of sanctuaries was the object of a mixed devotion (Ben Ami 1990). 
As a whole, in the Mediterranean, where people of different religions coexist, one observes a regular implantation of manifestations of shared worship and the emergence of a variety of what Frederick Hasluck defined as "ambiguous sanctuaries". In spite of the exclusivist tendencies typical of a monotheistic milieu, and of the fears of pollution stemming from contact with the 'other', ordinary devotional practices often blurred religious distinctions. Actors' use of religious resources can be relatively detached from the realm of ideas, beliefs, and practices which define the institutional core of a denomination. Interfaith practices evade the establishment of coherent and monolithic groups and identities. They are an emanation of an efficacy-based religiosity: the hope of material help and relief pushes the faithful to explore other religions' "pantheons" and frequent "foreign" sanctuaries.

The supernatural agents who charge the "plural" sanctuaries with their spiritual power may be local figures with an indeterminate profile, and therefore easily appropriated by individuals of different faiths. Frequently, devotions converge on holy figures that are recognised by different religious traditions. This is the case with certain biblical personages, such as Abraham and Moses or the Virgin Mary, who has an important role both in Christianity and in Islam. Moreover, there are figures that are part of a religious tradition but also allow shifts towards other religions, like the Koranic character of Khidr, sometimes perceived as a transfiguration of Saint George or the prophet Elijah. But Muslims can venerate even irrevocably monoconfessional saints, such as Saint Anthony of Padua, for example, in Albania and Turkey (Albera and Fliche 2012).

The diffusion of these devotional confluences is attested to at all times. In some cases, it is possible to identify longitudinal sequences of very long duration for some sites, from the Middle Ages to today, as in the case of several Marian shrines dear to Muslims. As early as the tenth century, Eutychius, a Melchite Patriarch of Alexandria, reported that Muslims gathered for prayer in the Church of the Nativity in Bethlehem. In the following centuries, accounts of Christian pilgrims constantly report the presence of Muslims who came to Bethlehem to worship the Virgin and her Child here. The frequentation of the Bethlehem church by Muslim devotees has continued until today, and this is far from the only example of such a mixed attendance spanning on several centuries (see Albera 2012).

Interreligious porosities occurred more frequently and with a more pronounced historical continuity in the southern and eastern sectors of the Mediterranean, where the human landscape has been marked by religious pluralism, mainly due to the relative tolerance of Muslim governments concerning Christian and Jewish minorities. Viewed in the long term, polytropic attitudes are inscribed in an ancient Mediterranean order made of enclaves and connections, in a patchwork of territories, peoples, and local 
cults (Hauschild et al. 2007). This ancient order has gradually collapsed. Transformation has become particularly rapid in the twentieth century as a result of economic change, urbanization and, above all, the process of ethnoreligious homogenization and polarization of identity. The clash of bellicose nationalisms has definitively altered the ethnic and religious profile of the southern and eastern Mediterranean through a process of homogenization that put an end to centuries of coexistence, and made interreligious sharing more difficult. The construction of religion-based nationalisms led to a new rigidity on the Muslim side, accompanied by the development of fundamentalist tendencies influenced by Wahhabism. Since at least the past one hundred years, everything seems to be leading to the closure of religious frontiers, to a narrowly defined identity politics, and to a strict policing of devotional practices. Nevertheless, even in this highly problematic context, and despite recurrent political and religious tensions, it is possible to look for signs of porosity (see, for instance, some cases examined in Valtchinova 2010 and Albera and Couroucli 2012).

The rapid comparative incursion sketched on the previous pages suggests that polytropic trends and efficacy-based religiosity cannot be interpreted uniquely, and even predominantly, in cultural terms, linking them to a particular social and cultural environment, be this Indic or Chinese, or more generally Asian, like Carrithers, Gellner, and Chau seem to suggest. The presence of polytropic traits in monotheistic religions even in the Mediterranean region, which is far removed from the Asian cultural environment, points to the need for a different perspective. The notion of polytropy, in other words, may be conceived of as a crucial component of a general, comparative theory of religious action in "world religions".

In conclusion, it seems possible to expand the scope of the "religious congruence fallacy" pointed out by Chaves. A comparative examination of religious actions crossing the borders of religious systems permits adding some corollaries to Chaves' argument and individuating at least two strictly related forms of fallacy in received wisdom on religious behaviour. I suggest calling the first form "religious uniformity fallacy" (postulating that individuals inscribed in a religious culture "naturally" conform only to the rites their religion proposes and congregate only with co-religionists) and the second "religious belonging fallacy" (maintaining that individuals necessarily belong to a religion, and that they cannot belong to more than one religion at the same time).

\section{Trailing Clouds of Etymology}

As is well known, the creation of notions-a particularly fertile activity in social sciences-is not without risks and problems. According to the empiricist position, 
classically illustrated by Vilfredo Pareto (1935, I, 62-5), each notion is purely a matter of convenience. Faithful to his logico-experimental method, Pareto observed that the "thing" comes before the word. For him only "things" matter, while words are simply etiquettes: their technical meaning depends exclusively on the definition that the researcher gives them. Pareto asked his readers to absolutely avoid reconsidering the technical terms he proposed by looking at their etymology. In contrast, a philosophically oriented approach adopts a very different stance, attributing a great importance to etymology. According to this perspective, as it was nicely put by Austin, words are "trailing clouds of etymology", since a word never "shakes off its etymology and its formation" (1956-57, 27).

In his article, Carrithers states that he has coined the word polytropy by combining two Greek words, and other authors have acknowledged his coinage (Gellner 2005; Chau 2011; 2012). In fact, it may better be qualified as the independent reinvention (in the field of religious anthropology) of a word that nevertheless had a previous and independent existence in other scientific domains. Polytropy has, for instance, been employed in natural sciences to describe interchange of both heat and work between a system and its surroundings (Sandler 2014). More crucially, the word polytropy cannot be considered merely as one of the many recent terms created ex-novo on the basis of Greek expressions. As a matter of fact, it already existed in ancient Greece and carries an important history with it. Let us see if this remote history may have any connection with the technical meaning attributed to it by Carrithers and other anthropologists (and to what extent this can possibly contribute to an enrichment of the semantic content of this notion).

In ancient Greek, the word polutropia meant "versatility, craft, multifariousness, variety" (Liddell and Scott 1940). The corresponding adjective polutropos has many occurrences in Greek literature, with the meaning of "shifty, versatile, wily". Significantly, this notion is connected with Hermes, the "divine trickster". Above all, polutropos is an epithet that accompanies descriptions of Odysseus. In the very first line of the Odyssey, the protagonist is evoked as the polutropos man. Later in the poem (Odyssey X, 330), Circe defines Odysseus as polutropos, describing his resourcefulness, which permitted him to successfully resist her magic (Pucci 1987).

A polutropos man is characterized by his mobility. He is flexible, undulating, and unstable only in appearance. His flips are the stratagems to escape a trap, or the tricks by which he tries to seize his opponent. Usually associated with Odysseus, polutropos defines his character of crafty and astute warrior. A long literary tradition has been concerned with this topos. Odysseus' polutropia was the subject of criticism in fifthcentury poetry (Pindar) and tragedy (Sophocles and Euripides), and considered as the manifestation of a deceitful personality. In contrast, the figure of Odysseus pulotropos 
was assessed more positively in later philosophical texts, like Antisthenes' Fragments and Plato's Hippias Minor, as the positive features of an enduring, skilled, and intelligent person. In these works, the polytropic, complex nature of Odysseus is contrasted with the "true and simple" personality of, respectively, Ajax and Achilles (Lévystone 2005; Adams 2010).

More generally, the word polutropos is associated with other terms, such as polumekanos or polumetis, meaning "cunning, shrewd, ingenious, with many tricks". Along with these terms, it is inscribed in the general semantic field of the mêtis (which is exemplified again by the mythical figure of Odysseus). As Detienne and Vernant have showed in their classical work on this subject, mêtis is practical, cunning knowledge, distinct from formal knowledge (episteme). Mêtis is associated with trickery and deceit, it combines flair, subtlety of mind, resourcefulness, and opportunism, and applies to situations that are transient and mobile:

In the first place, the intelligent ability referred to as mêtis comes into play on widely varying levels, but in all of them the emphasis is always laid on practical effectiveness, on the pursuit of success in a particular sphere of activity: it may involve multiple skills useful in life, the mastery of the artisan in his craft, magic tricks, the use of philtres and herbs, the cunning stratagems of war, frauds, deceits, resourcefulness of every kind. (Detienne and Vernant 1991, 1)

Detienne and Vernant characterize some aspects of mêtis. First, the success of an action does not depend on the use of force (which the subject of mêtis often lacks), but on "the use of methods of a different order whose effect is, precisely, to reverse the natural outcome of the encounter and to allow victory to fall to the party whose defeat had appeared inevitable" (ibid., 13). Second, there is an essential temporal component. The man of mêtis should always be ready to seize an opportunity, to acquire mastery over the kairos. Third, the mêtis is not unified but multiple and diverse (and this aspect resonates particularly with the specific domain of polutropia): "Odysseus is the hero who is polumetis as well as polutropos and polumechanos. He is an expert in tricks of all kinds (pantoious dolous, polumechanos) in the sense that he is never at a loss, never without expedients (poroi) to get himself out of any kind of trouble (aporia)" (ibid., 18). Mêtis appears as multiple (pantoie), many-coloured (poikile), and shifting (aiole) because "its field of application is the world of movement, of multiplicity and of ambiguity" (ibid., 20). Fourth, mêtis operates through disguise and "is itself a power of cunning and deceit" (ibid., 21). As a consequence, a man of mêtis is also a master of masks and illusions. 
This brief exploration of the ancient roots of the word polytropy and of its echoes within cognate semantic domains is presumably useless with regard to the contemporary use of this notion in the fields of physics or astrophysics. On the contrary, it resonates quite intensely with the meaning of the contemporary, technical notion introduced by Carrithers in the field of the anthropology of religion, designating an efficacy-based religiosity, conveyed in actions more than in states of mind or discursive assertions, and characterized by a great exuberance, like a Brownian motion or a vegetative growth (to use Carrithers' expressions). In several respects, Odysseus polutropos reverberates with more recent, anonymous religious practices conveyed by the notion of polytropy. In the Asian or Mediterranean cases that we have considered, polytropic behaviours of ordinary people seem to operate in the framework of a practical, cunning intelligence, akin to Greek polutropia and mêtis.

\section{The Indefinite Plurality of Believing}

To what extent may the "clouds of etymology" that the word polytropy carries with it enrich its technical meaning conceived by Carrithers in relation to religious studies? The association between polutropia and mêtis suggests that religious polytropy pertains to the domain of cunning intelligence, above all interested in attaining practical effectiveness. It is an attempt to seize an opportunity wherever available. It is multiple and many-colored. It is the expression of a flexible, ingenious, and shifting approach. I will briefly pursue the trail offered by these associations by building a bridge between polytropy and some aspects of Michel de Certeau's thought.

Michel de Certeau inscribed the practices linked to the Greek mêtis in a wider characterization of tactic as opposed to strategy. For him, the strategic model is typical of political, economic, and scientific rationality: "A strategy assumes a place that can be circumscribed as proper (propre) and thus serve as basis for generating relations with an exterior distinct from it" (de Certeau 1984, xix). On the contrary, a tactic does not possess a place, but "insinuates itself into the other's place, fragmentarily, without taking it over in its entirety, without being able to keep it at a distance" (ibid.). The tactic cannot capitalize on its advantages; it depends on circumstances, and tries to turn external events into opportunities. A tactic is the art of combining heterogeneous elements whose synthesis takes the form "not of a discourse, but of the decision itself, the act and manner in which the opportunity is seized" (de Certeau 1984, XIX).

In several respects, polytropic religiosity corresponds to a tactical infiltration of the weak in a territory that is alien to them, trying to get along in a network of already established forces and representations, and turn them to their own end. In general, 
ordinary faithful lack control of the theological, ritual, and architectural elements that make up a religious tradition. Using de Certeau's language, their polytropic wanderings may be defined as clever tricks within an alien order, established by a more strategic intentionality.

Moreover, polytropic religiosity may be seen as a manifestation of a tactic of the weak at a second level as well, less sociological and more existential. Facing constantly problematic and often menacing human and natural worlds and an enigmatic array of supernatural forces, the individual tries to take the opportunity, in spite of the shifting terrain and the mysterious turns of fate. Thus, in a condition of incertitude, the practical, cunning intelligence increases its chances by multiplying the directions of its quest and augmenting the number of its supernatural interlocutors.

Such a religiosity is linked to a specific conception of believing, on which Michel de Certeau's $(1981 ; 1983)$ reflections again offer challenging hints. In this conception, believing means to 'give credit' to a recipient. It is an act that implies both a different partner and a deferred repayment; it creates a reference to the Other and to the future. Believing produces a relational commitment whereby something is given to someone else, an 'Other', pending a reward from them. This requires that the latter recognizes the obligation and is able to do what is asked. Therefore, the deployment of belief is padded with uncertainties. Without ever being assured of his or her bet, the believer is moved to multiply the transactions with the supra-mundane partners who could meet the demands. Consequently, according to de Certeau, mobility is a dominant feature of the act of believing. In the search of a respondent, the believer tends to compensate for his or her uncertainty by an endless reference to a multiplicity of supernatural 'Others'. Moreover, in the absence of any certainty, the believer relies on the fact that other people believe in the action of supra-mundane guarantors. Even from this point of view, the process of believing proceeds from an indefinite plurality, very much like 'opinion' does. This is the domain designated by expressions like 'it is believed', 'they believe'. Hence emerges a general, neutral authorization of the belief. De Certeau defines this dimension as that of 'plausibility', whose subject remains undetermined.

Many examples may be associated with the mechanisms of this type of believing, from the votive religion in Antiquity (whose talismans, amulets, and ex-voto have been accumulated in so many contemporary museums) to the cult of saints in monotheistic faiths to the puja in South Asia to pluralistic rituals in China. From this point of view, polytropy may be seen as a "natural" outcome of the mobility and the indefinite plurality of believing. 


\section{Monotropy}

Through a kind of gestalt effect, the discernibility of polytropy depends on the action of another, opposite way of conceiving religious behaviour. The "spiritual cosmopolitanism" embedded in the modus operandi of polytropy implies the existence of separate (and possibly incompatible or antagonist) established religious traditions, comparable to "religious countries" or "poleis" in which the carriers of polytropic religiosity may circulate, feeling more or less at home everywhere. In other words, polytropy supposes the existence of symbolic frontiers between religious traditions: the multidirectional movements of the quest that characterises this type of religiosity become visible precisely when they cross these frontiers, whose nature is obviously variable.

It is tempting to identify the opposite pole to polytropy as monotropy, in which people tend to turn towards a unique direction of spiritual relief. As we have seen, polytropy does not have a fixed shape: it is multiple, unstable, and fluid, it adopts a plastic, inventive, kaleidoscopic, and ever-changing approach. In contrast, monotropy may be characterized as a religious attitude that tends towards unity, uniformity, coherence, stability, and continuity. Monotropy corresponds to the tendencies that assure internal coherence of a given religious tradition in its particular physiognomy and consistency. It gives voice to the inclination for orthodoxy and orthopraxy, whatever the range and the intensity of these tendencies, be they reserved to a tiny minority of religious specialists and lay virtuosi, like in Chinese religions, or ideally extended to all the people, like in the monotheisms. Monotropic tendencies occupy the centre of the stage, as it were, in any religious traditions. They define its core and its frontiers. They have a strategic quality: they possess a place that can be circumscribed as proper, in de Certeau's terms, while polytropic trends correspond to the domain of subaltern tactics.

Monotropic tendencies towards unity, uniformity, and coherence are central in the working of religious institutions and contribute to selecting and refining assertions, to giving them the form of a doctrine by introducing determinations and producing order, and to organizing allowed ritual practice. In this way, each religious institution isolates and authorizes specific contents in the global sphere of what is credible and defines the sphere of a different kind of plausibility, which alters the general, neutral authorization of the belief (de Certeau 1981; 1983).

Monotropic propensities are the main inheritors of the breakthrough in different Euro-Asian cultural systems that the philosopher Karl Jaspers has identified with the term 'Axial Age'. This movement involved a radical questioning of existing traditions and a critical examination of accepted ideas and customs. This antagonistic secondorder thinking, which affirmed its legitimacy against previous forms of religiosity, is the 
main matrix of the current great religious systems, often designated with the label of "world religions". In this context, without monotropic tendencies, it would be impossible to ensure the continuity and stability of any religious tradition. The channels through which monotropic sensibilities become manifest in religious action are manifold: they include a discursive and scriptural style of religiosity; self-cultivation, also with ascetic practices; a concentration on soteriology and transcendence; ethical and spiritual tension; a pursuit of unity and coherence. The main carriers of these forms of religiosity are several strands of religious specialists and of virtuosi, while lay masses, in contrast, constitute polytropy's more receptive field. But it would be mistaken to attribute an absolute fixity to these sociological incarnations of forms of religiosity. Even if the dominance of a trend is generally quite clear, there is possible middle ground and the somewhat challenging coexistence of opposite tendencies in the same group, or even within the same person. Put differently, it is important to avoid excessive simplifications which become caricatures when one forgets that the models are heuristic devices that simplify reality and cannot entirely replace it. Polarities like polytropy and monotropy rarely exist in pure form in the concrete world and should obviously be contextualized. From this point of view, it is better to speak of tendencies rather than of objective conditions.

Monotropic tendencies are inner-directed: they are orientated by centripetal forces at work within a religious tradition. However, they are also concerned with what is situated "outside", with the "other", and cannot help but be involved in a series of interactions with separate religious traditions, generating a wide range of outputs. The identikit of an absolute purist and rigorist personality which refuses any compromise and promotes a strong antagonism with other religions does correspond to people that one can encounter in the real world. But the zealot surely cannot be seen as the only incarnation of these tendencies, and as a matter of fact, the range of positions in the monotropic field is considerably wider. Religious specialists, who are the main bearers of a religious system, may often accommodate lay people's polytropic trends, which they accept and also encourage, even if they don't personally adhere to these forms of religiosity. They may also extend this "tolerance" to incursions by the faithful of another religion into the field that they control. Furthermore, a particular position is occupied by mystical tendencies. In this case, an extreme quest for unity and uniformity may sometimes relativize the frontiers between religions, generating a somewhat paradoxical monotropic "spiritual cosmopolitanism", like in the case of some Sufi paths. Moreover, the official representatives of religious traditions have been increasingly engaged in forms of interreligious dialogue in the last decades through theological discussions, encounters, and common ceremonies. But it suffices to compare a formal 
interreligious ceremony with a spontaneous pilgrimage at a shared shrine to grasp to what extent different logics of religious action are at work in these two contexts.

Likewise, polytropic tendencies have a general quality that cannot be reduced to the crossing of religious borders. This is only one of the manifestations of a propensity to multi-directional worship, which may be effective also in a mono-religious setting. It is only in a pluralist situation, when multiple denominations are present in the same territory and generate an increasing stock of available religious resources, that polytropic propensities may produce the crossing of religious frontiers, so acquiring greater visibility.

In relation to monotropy, it is also possible to add some etymologic considerations. In its turn, in fact, this notion has a complex history. It is used in contemporary chemistry and physics to describe a type of polymorphism in which a material could exist in multiple forms, and only one of these forms is stable, while all others are unstable. Monotropy has also been employed in psychology to define a child's bias to attach to one person in particular (Prior and Glaser 2006, 63-4). However, the word already existed in Ancient Greek. Monotropia meant "uniformity, simplicity", while the related word monotropos had a wider semantic range, designating both 1) someone who has only one manner of being, who is simple, with a unified character, and 2) someone who lives alone, a solitary, unmarried person, and even a misanthrope (Bailly 1935). It is easy to see the logic of this double meaning. The prefix mono may refer either to the goal of the turn, or to the situation of the subject who is turning. In both these meanings, this word experimented further elaboration in early Christian thought. Among the Greek fathers, the monastic life was characterized as monotropos, meaning a celibate life, but also and above all a unified behaviour constantly focusing on a dialogue with God. For instance, Saint Basil (fourth century) compared the life of the "true" Christian, exemplified by the monk, to secular life: the former is monotropos, pursuing the only goal of glorifying God, while the latter is multiple and variegated (Saint Basil defines it as polutropos and poikilos, two terms with which we are already familiar) ${ }^{3}$. As is easy to see, the etymology here seems to corroborate significantly with the technical meaning attributed to this term in the previous pages.

\section{Conclusion}

In this article, I have tried to situate the discussion of multifaith frequentation of the same sacred places in the wider framework of the analysis of religious action.

3 For a valuable discussion of the notion of monotropia in relation to monasticism, see Guillamont 1972. 
A comparative perspective suggests that the notion of polytropy (introduced by Carrithers in his work on India) could offer a useful tool for describing some features of religious actions whose constitutive qualities are diversity and multiplicity. The notion of polytropy seems to be an analytical tool that is able to describe a vast array of situations, well beyond the Indic milieu in which it was forged. A move towards the Mediterranean has permitted enlarging the scope of this notion. It has become clear that polytropy is not a "cultural" quality of Asian religiosity, but that it may be an analytical tool for grasping the multi-layered domain of religious action in the framework of "world religions". Polytropy emerges in various religious contexts, from the fuzzy Chinese situation, where religious affiliations are very limited in their scope and relevance, to the South Asian context, in which religious orientations coalesce around the multivocal concept of dharma, to the tightly structured monotheistic faiths in the Mediterranean. In this vast array of situations, polytropic trends are associated with an efficacy-oriented religiosity.

Moreover, a second move towards the Mediterranean, this time under the form of a genealogical and etymological exploration of this notion in Ancient Greece, has shown correspondence with the technical meaning put forward by Carrithers. Polutropia is associated with the semantic field of mêtis, and this suggested the inscription of religious polytropic behaviours in the framework of a practical, cunning intelligence, characterized by a flexible and shifting approach. Drawing on Michel de Certeau's distinction between tactics and strategy, I have suggested that polytropic religiosity corresponds to a tactical infiltration of a religious territory already defined in its theological and ritual elements by a more strategic intentionality.

Polytropy is associated with a practical mode of religiosity, primarily linked to intramundane goals. This raises the question of how to conceptualize belief in relation to this type of religious action. Developing some arguments put forward by de Certeau, I have suggested that polytropy is linked to a particular conception of believing in which the believer tends to multiply the transactions with different supra-mundane partners. This orientation is distinct from religious styles that are based on a discursive and scriptural approach, on self-cultivation, and on transcendental and soteriological aims, which often display a tendency towards unity, coherence, and continuity. This has permitted us to identify the opposite pole to polytropy, which I defined as monotropy. In several respects, this polarity between polytropic and monotropic tendencies seems to globally characterise post-axial religious systems, naturally with distinct outcomes regarding the strength of their contrast and the equilibrium point between them.

Monotropic tendencies are only one part of the religious landscape in "world religions", but they undoubtedly have a hegemonic position, especially in the monotheistic environment, and have shaped the common wisdom of what religious 
behaviour is expected to be. This may contribute to explaining the pervasive influence of a number of wrong assumptions about coherence and unity in religious attitudes: they are at the basis of some conundrums expressed by formulas like "religious congruence fallacy" or "religious uniformity fallacy".

\section{References}

Adams, Don. 2010. "Socrates polutropos?" Apeiron 43 (1): 33-62.

Albera, Dionigi. 2012. "Combining Practices and Beliefs: Muslim Pilgrims at Marian Shrines." In Sharing the Sacra. The Politics and Pragmatics of Inter-Communal Relations Around Holy Places, edited by Glenn Bowman, 10-24. New York: Berghahn Books.

Albera, Dionigi, and B. Fliche. 2012, "Muslim devotional practices in Christian shrines: the case of Istanbul." In Sharing Sacred Spaces in the Mediterranean. Christians, Muslims, and Jews at Shrines and Sanctuaries, edited by Dionigi Albera and Maria Couroucli, 94-117. Bloomington: Indiana University Press.

Albera, Dionigi, and Maria Couroucli, eds. 2012. Sharing Sacred Spaces in the Mediterranean. Christians, Muslims, and Jews at Shrines and Sanctuaries. Bloomington: Indiana University Press.

Assayag, Jackie. 1995. Au confluent de deux rivières. Musulmans et hindous dans le sud de I'Inde. Paris: Presses de l'École française d'Extrême-Orient.

Assayag, Jackie, and Gilles Tarabout, eds. 1997. Altérité et identité. Islam et christianisme en Inde. Paris: Éditions de l'EHESS.

Austin, John L. 1956-57. “A Plea for Excuses: The Presidential Address." Proceedings of the Aristotelian Society, New Series 57: 1-30.

Bailly, Anatole. 1935. Dictionnaire Grec-Français. Paris: Hachette.

Barkan Elazar, and Karen Barkey, eds. 2014. Choreographies of Shared Sacred Sites. Religion and Conflict Resolution. New York: Columbia University Press.

Bayly, Susan. 1989. Saints, Goddesses and Kings: Muslims and Christians in South Indian Society, 1700-1900. Cambridge University Press: Cambridge.

Bellamy, Carla. 2011. Everyday Healing in an Ambiguously Islamic Place. Berkeley and Los Angeles: University of California Press.

Ben-Ami, Issachar. 1990. Culte des saints et pèlerinages judéo-musulmans au Maroc. Paris: Maisonneuve et Larose.

Bigelow, Anna. 2010. Sharing the Sacred. Practicing Pluralism in Muslim North India. Oxford: Oxford University Press. 
Boivin Michel. 2005. "Le pèlerinage de Sehwân Sharif, Sindh (Pakistan): territoires, protagonistes et rituels." In Les pèlerinages au Moyen-Orient: espaces publics, espaces du public, edited by Silvia Chiffoleau and Anna Madoeuf, 311-345. Damascus: Institut Français du Proche-Orient.

Bowman, Glenn, ed. 2012. Sharing the Sacra. The Politics and Pragmatics of Intercommunal Relations around Holy Places. Oxford: Berghahn Books.

Carrithers, Michael. 2000. "On Polytropy: Or the Natural Condition of Spiritual Cosmopolitanism in India: The Digambar Jain Case." Modern Asian Studies 34 (4): 831-861.

de Certeau, Michel. 1981. "Une pratique sociale de la différence: croire." In Faire croire. Modalités de la diffusion et de la réception des messages religieux du XII ${ }^{\mathrm{e}}$ au XVe siècle. Actes de table ronde de Rome (22-23 juin 1979), 363-83. Rome: École Française de Rome.

-_- 1983. "L'institution du croire : note de travail." Recherches de Science Religieuse 71: 61-80.

- - . 1984. The practice of everyday life. Berkeley and Los Angeles: University of California Press.

Chaves, Mark. 2010. "Rain Dances in the Dry Season: Overcoming the Religious Congruence Fallacy." Journal for the Scientific Study of Religion 49 (1): 1-14.

Chau, Adam Yuet. 2011. "Modalities of Doing Religion and Ritual Polytropy: Evaluating the Religious Market Model from the Perspective of Chinese Religious History." Religion 41 (4): 533-554.

- - . 2012. "Efficacy, Not Confessionality: On Ritual Polytropy in China." In Sharing the Sacra. The Politics and Pragmatics of Intercommunal Relations Around Holy Places, edited by Glenn Bowman, 79-96. Oxford: Berghahn Books.

Chiffoleau, Silvia, and Anna Madoeuf, eds. 2005. Les pèlerinages au Moyen-Orient: espaces publics, espaces du public. Damascus: Institut Français du ProcheOrient.

Cormack, Margaret, ed. 2013. Muslims and Others in Sacred Space. Oxford: Oxford University Press.

Detienne, Marcel, and Jean-Pierre Vernant. 1991. Cunning Intelligence in Greek Culture and Society. Chicago: University of Chicago Press.

Dundas, Paul. 1992. The Jains. London: Routledge.

Frøystad, Kathinka. 2012. "Divine Intersections: Hindu Ritual and the Incorporation of Religious Others." Cosmopolitan Civil Societies Journal 4 (2). https://epress.lib. uts.edu.au/journals/index.php/mcs/article/view/2589.

Gellner, David. 1992. Monk, Householder, and Tantric Priest: Newar Buddhism and its Hierarchy of Ritual. Cambridge University Press: Cambridge. 
- - . 2005. "The Emergence of Conversion in a Hindu-Buddhist Polytropy: The Kathmandu Valley, Nepal, c.1600-1995." Comparative Studies of Society and History 47 (4): 755-780.

Gellner, David, and Sondra L Hausner. 2013. "Multiple versus Unitary Belonging: How Nepalis in Britain Deal with 'Religion'." In Social Identities between the Sacred and the Secular, edited by Abby Day, Giselle Vincett, and Christopher R. Cotter, 75-88. Farnham \& Burlington VT: Ashgate.

Grapard, Allan G. 1984. “Japan's Ignored Cultural Revolution: The Separation of Shinto and Buddhist Divinities in Meiji (Shimbutsu Bunri) and a Case Study: To -no-Mine." History of Religions 23 (3): 240-265.

Guillamont, Antoine. 1972. "Monachisme et éthique judéo-chrétienne." In Judéochristianisme: Recherches historiques et théologiques offertes en hommage au cardinal Jean Daniélou, 199-218. Paris: Recherches de Science Religieuse (Tome 60).

Hasluck, Frederick W. [1929] 2000. Christianity and Islam Under the Sultans. Istanbul: The Isis Press.

Hauschild, Thomas, Sina L. Kottmann, and Martin Zillinger. 2007. "Syncretism in the Mediterranean: Universalism, Cultural Relativism and the Issue of the Mediterranean as a Cultural Area." History and Anthropology 18 (2): 309-332.

Hausner, Sondra L., and David Gellner. 2012. "Category and Practice as Two Aspects of Religion: The Case of Nepalis in Britain." Journal of the American Academy of Religion 80 (4): 971-997.

Hayden, Robert M., Aykan Erdemir, Tuğba Tanyeri-Erdemir, Timothy D. Walker, Devika Rangachari, Manuel Aguilar-Moreno, Enrique López-Hurtado, and Milica BakićHayden. 2016. Antagonistic Tolerance. Competitive sharing of religious sites and spaces. New York: Routledge.

Kilpatrick Hilary. 2003. "Monasteries through Muslim eyes: The diyarat books." In Christians at the Heart of Islamic Rule. Church Life and Scholarship in 'Abbasid Iraq, edited by David Thomas, 19-37. Leiden: Brill.

Kinzing, Wolfram. 1991. “'Non-Separation': Closeness and Cooperation between Jews and Christians in the Fourth Century." Vigiliae Christianae, 45 (1): 27-53.

Landron, Bénédicte. 1994. Chrétiens et musulmans en Iraq: attitudes nestoriennes vis-à- vis de l'islam. Paris: Cariscript.

Lévystone, David. 2005. "La figure d'Ulysse chez les Socratiques: Socrate polutropos." Phronesis 50: 181-214.

Liddell, Henri George, and Robert Scott. 1940. A Greek-English Lexicon, revised and augmented throughout by Sir Henry Stuart Jones with the assistance of Roderick McKenzie. Oxford: Clarendon Press. 
Mosse, David. 1994. "Catholic Saints and the Hindu Village Pantheon in Rural Tamil Nadu, India." Man, NS 29 (2): 301-332.

Pareto, Vilfredo. 1935. The Mind and the Society. New York: Harcourt, Brace and Company (IV volumes).

Prior, Vivien, and Dania Glaser. 2006. Understanding Attachment and Attachment Disorders: Theory, Evidence and Practice. London: Jessica Kingsley Publishers.

Pucci, Pietro. 1987. Odysseus Polutropos: Intertextual Readings in the Odyssey and the Iliad. Ithaca (NY): Cornell University Press.

Reader, Ian. 1991. Religion in Contemporary Japan. Honolulu: University of Hawaii Press.

Sandler, Stanley I. 2014. "Polytropic process." AccessScience. https://doi. org/10.1036/1097-8542.537300.

Sébastia, Brigitte. 2002. "Māriyamman-Mariyamman. Catholic practises and image of Virgin in Velankanni (Tamil Nadu)." Pondy Papers in Social Sciences 27 (Institut Français de Pondichery).

-_- 2007. Les rondes de Saint Antoine. Culte, affliction et possession en Inde du Sud. Montreuil: Aux lieux d'être.

Sekimori, Gaynor. 2005. "Paper Fowl and Wooden Fish. The Separation of Kami and Buddha worship in Haguro Shugendo, 1869-1875." Japanese Journal of Religious Studies 32 (2): 197-234.

Shepardson, Christine C. 2007. “Controlling Contested Places: John Chrysostom's Adversus ludaeos Homilies and the spatial politics of religious controversy." Journal of Early Christian Studies 15 (4): 483-516.

Sikand, Yoginder. 2002. "Hindu-Muslim Syncretic Shrines of Karnataka." Indian Journal of Secularism 6 (1): 63-97.

- - . 2003. Sacred Spaces: Exploring Traditions of Shared Faith in India. New Delhi: Penguin India.

Sozomène, 1983. Histoire ecclésiastique, Edited by Bernard Grillet and Guy Sabbah, translated by André-Jean Festugière. Paris : Cerf

Tuladhar-Douglas, Will. 2012. "The Work of Mending: How Pharing People Manage an Exclusivist Response to the Procession of Vajrayoginī." In Sharing the Sacra: The Politics and Pragmatics of Inter-Communal Relations Around Holy Places, edited by Glenn Bowman, 61-78. New York: Berghahn Books.

Thal, Sarah. 2005. Rearranging the Landscape of the Gods. The Politics of a Pilgrimage Site in Japan, 1573-1912. Chicago and London: Chicago University Press.

Valtchinova, Galia, ed. 2010. Religion and Boundaries. Studies from the Balkans, Eastern Europe and Turkey. Istanbul: The Isis Press. 
Vinson, Martha. 1994. “Gregory Nazianzen's Homily 15 and the Genesis of the Christian cult of the Maccabean martyrs." Byzantion 64 (1): 166-92.

Younger, Paul. 1992. "Velankanni Calling: Hindu Patterns of Pilgrimage at a Christian Shrine." In Sacred Journeys. The Anthropology of Pilgrimage, edited by Alan Morinis, 89-99. Westport: Greenwood Press. 


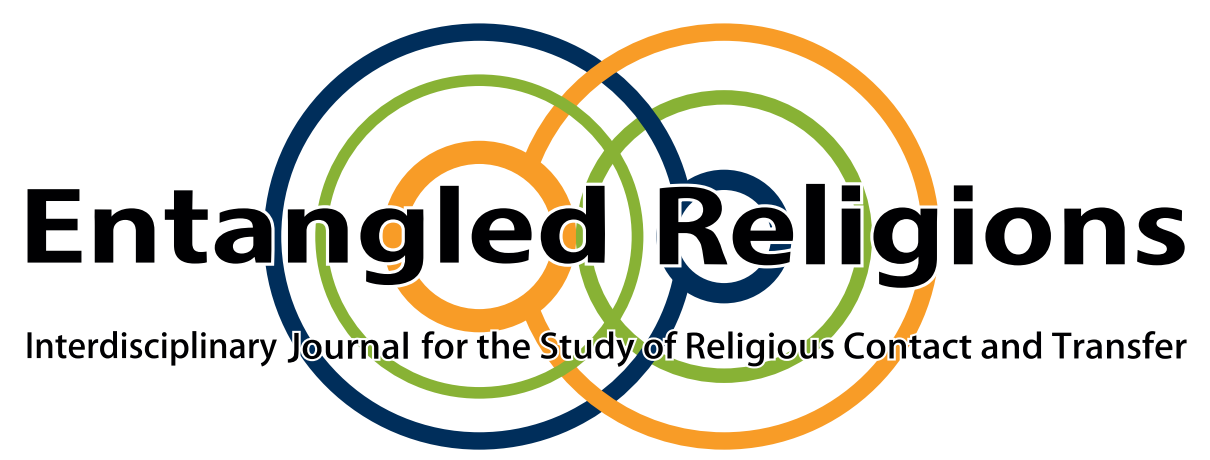

\section{Where Do the Multi-Religious Origins of Islam Lie?}

\section{A Topological Approach to a Wicked Problem}

MANFRED SING

Leibniz Institute of European History, Mainz, Germany

This contribution to Entangled Religions is published under the Creative Commons Attribution 4.0 International Public License (CC BY 4.0 International). The license can be accessed at https://creativecommons.org/licenses/by/4.0/legalcode.

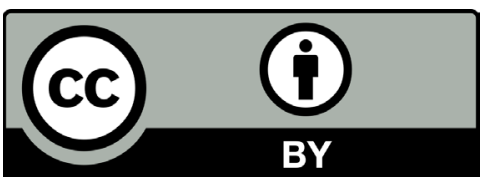

Entangled Religions 9 (2019) http://doi.org/10.13154/er.v9.2019.165-210
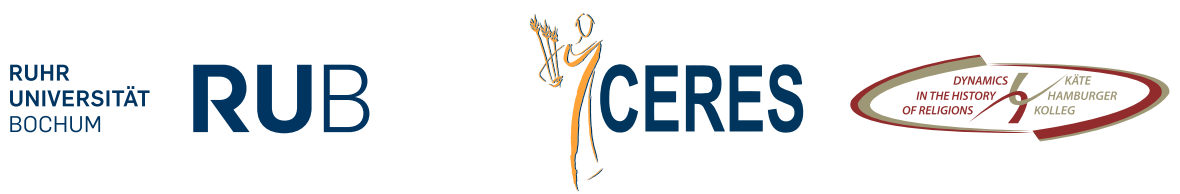

SPONSORED BY THE 


\title{
Where Do the Multi-Religious Origins of Islam Lie?
}

\author{
A Topological Approach to a Wicked Problem
}

\author{
MANFRED SING \\ Leibniz Institute of European History
}

\begin{abstract}
The revelation of Islam in Arabic, its emergence in the Western Arabian Peninsula, and its acquaintance with Biblical literature seem to be clear indications for Islam's birthplace and its religious foundations. While the majority of academic scholarship accepts the historicity of the revelation in Mecca and Medina, revisionist scholars have started questioning the location of early Islam with increasing fervour in recent years. Drawing on the isolation of Mecca and the lack of clear references to Mecca in ancient and non-Muslim literature before the mid-eighth century, these scholars have cast doubt on the claim that Mecca was already a trading outpost and a pilgrimage site prior to Islam, questioning the traditional Islamic and Orientalist view. Space, thus, plays a prominent role in the debate on the origins of Islam, although space is almost never conceptually discussed. In the following paper, I challenge the limited understanding of space in revisionist as well as mainstream scholarship. For the most part, this scholarship is not really interested in the multi-religious landscape sui generis, but understands early Islam either as a stable or an unstable entity that either reworked or digested the impact of Judaism and Christianity. In contrast, my contention is based on the view that Islam emerged neither "in" Mecca nor anywhere else, but that Muslims' practical and symbolic actions produced such places as Mecca, Medina, and the Hijāz as the central places of Islam. My argument is threefold: Firstly, the production of the Meccan space and its central meaning for Islam were mutually dependant, gradual processes. Secondly, the creation of an exclusively Muslim space in the Hijāz conversely inscribed multi-religiosity into the general topology of early Islam. Thirdly, the early history of Islam hints at practices of un/ doing differences, exemplified by instances of sharing, the creation of ambivalence, and processes of purification. Moreover, my contribution questions the way in which research on the origins of Islam has become a meaningful object of knowledge about the "true" nature of Islam against the background of populist discourses on Islam.
\end{abstract}

KEY WORDS Inter-religious contact; production of space; emergence of Islam; Genesis of the Qur'ān; Mecca and Medina

\section{Introduction}

The emergence of Islam in Mecca and Medina and its revelation in Arabic seem to be, prima facie, a clear indication for the emplacement of early Islam in the Western 
Arabian Peninsula. However, so-called "revisionist" and "neo-revisionist"1 scholarshipwhich, according to its own claims, contests parts of Orientalist scholarship as well as most parts of the Islamic tradition-has started to question the location as well as the linguistic unambiguity of early Islam with an ever-growing verve in the last two decades. Revisionist scholarship has especially cast doubt upon Mecca and Medina as the birthplaces of Islam.

Mainstream and revisionist scholarship attributes much attention to the primordial places of Islam, either in order to uphold the traditional chronology and emplacement of early Islam or in order to deconstruct and reconstruct the historical centre of Islam. My objection to both approaches is that a limited understanding for the historical production of space is at work here, so that neither mainstream nor revisionist scholarship can adequately treat the intricate questions that they want to solve. That dominant scholarly approaches either take for granted or relocate the birthplace of Islam leads to a confusion between different spatial dimensions, especially between the physical and symbolic ones. It also blurs the boundaries between Qur'ānic genesis and exegesis and takes chronology for causality.

The question of what we actually know about the places in which Islam emerged in Late Antiquity is certainly worth a discussion. Revisiting Islamic origins with new methods is "an important desideratum," as scholar of religions studies Aaron Hughes $(2017,883)$ put it; yet this is certainly not so because the origins of Islam are different from the beginnings of other religious traditions. Instead, "there is some discrepancy between sources and tradition, as there are in all religions" (ibid., 872); the origins of Islam "are clouded in mystery, and are about human ingenuity and worldmaking in the midst of rapid change" (ibid., 869). What is different with Islam, however, are "the many political and ideological uses to which the discourse of Islamic origins have been put over the years" (ibid., 871). Because of this effect, revisionist discussions partly verge on Islamophobic sentiments, especially after 9/11, when the "Syro-Aramaic reading" of the Qur'ān hit the headlines by poking fun at martyrs, who will find, if at all, grapes, not virgins, in paradise (Luxenberg 2004; for a critique Wild 2010; Saleh 2010; Sinai 2012).

Having said this, I understand my critique of the debate about the emergence of Islam as a contribution that questions the heterogeneous scholarly research which implicitly aims to explain what Islam 'really' is, or is not, by looking at its possibly "dark

1 I use the term of "revisionist" and "neo-revisionist" scholarship in the sense of a "radically sceptical" approach to Islamic tradition and its sources. As these scholars do not follow a common agenda and differ in their methods, I use the term as a heuristic tool to distinguish them from scholars who, although sceptical, attribute more value to studying these sources and whom I call "mainstream." Since the boundaries are sometimes blurred between the two camps, I draw equally on "revisionist" as well as "mainstream" authors in this paper if I find their findings useful for the discussion on the production of space, irrespective of their belonging to different camps. 
origins" (Ohlig/Puin 2005). I do not concur with the diagnosis that Qur'ānic studies are, because of revisionist activities, in a state of "disarray" (Donner 2008, 29), since such "an assessment is best understood as a rhetorical appeal to the writer's own approach as compared to those of rival theories," as Andrew Rippin $(2013,60)$ has succinctly noted. I also cannot join in the enthusiasm about "the large-scale interest of the media that the Qur'an's origin and interpretation have solicited during the last decade or so" (Sinai/Neuwirth 2010, 1). Instead, I understand the historiography of early Islam not only as a complex, but a "wicked problem" 2 that is characterized by "intense disagreement between fragmented stakeholders, multiple and often conflicting objectives, as well as high levels of uncertainty, variability, and risk" (Lake 2014, 77). By participating in this debate, I question the self-affirming knowledge produced along institutional boundaries and ossified positions in Islamic tradition, mainstream scholarship, and revisionism. Based on the assumption that the underlying questions are not amenable to final resolutions, I argue for "supplanting initial divisive certainties with 'perplexities'" (ibid., 80). From a "sympathetic understanding" (ibid., 84) for different perspectives, I have invited these into a critical dialogue on the following pages. From an epistemological point of view, my critique focuses on three overlapping fields of knowledge production. Firstly, I am sceptical about the results of scholarly "parallelomania" (Sandmel 1962) that incessantly discloses similarities between the three monotheistic religions for paternalistic or defamatory reasons, although scholarship on Late Antiquity is certainly aware of these dangers (e.g. Koloska 2016, 431). Secondly, my critique follows from the impression that a good deal of scholarship in Qur'ānic studies confuses physical and symbolic space and is trapped either in age-old tropes on Islam or in a sort of back projection of later knowledge into the text. Thirdly, I question the general meaningfulness and importance that is acceded to scholarship on early Islam against the background of current popular debates on Islam.

In order to meet this objective, I firstly give an overview of the spatial knowledge that we have with regard to early Islam, especially with a focus on the absence of topographical terms in the Qur'ān. Then, I turn to the main arguments and counterarguments that speak in favour of or against a relocation of the birthplace of Islam. Next, I highlight the shortcomings in this debate. On the revisionist side, I focus on the lack of a new comprehensive chronology, the philological bias (or rather a biased philology), and the reductionism that focuses on Jewish-Christian text layers in the Qur'ān. On the mainstream side, I pinpoint, pars pro toto, some central findings from Qur'ānic studies in order to show that some researchers' emplacement of the Qur'ān blurs the historical and symbolical dimensions of space. Finally, I propose an alternative 
topological reading that tries to elucidate the production of a multi-religious landscape as well as a Muslim space in the Hijāz as a lasting process that cannot be reduced to the first decades of the history of Islam. My intention is to establish multi-religiosity as a central category to explain the process that led to the emergence of Islam in the first centuries of the history of Islam. In a diverse environment, practices of "un/doing differences" (Hirschauer 2014) were present from the very beginning and included different practical and symbolic actions, such as instances of sharing, the creation of ambivalence, and processes of purification.

\section{At the Origins of Islam}

It is a well-established fact that the Qur'ān has little concern with its own historical and geographical context (e.g. Reynolds 2010a, 198f.). Because of that, context is given to Qur'ānic verses by the two genres of sira, biographies of the life of the Prophet Muhammad, and tafsīr, comments on the Qur'ān, both of which developed approximately 150 to 200 years after Muhammad's death in 632. Without this additional literature, it is difficult to understand the Qur'ān on its own. The Qur'ān mentions Mecca only once explicitly (Q 48:24), but does not identify it as a city, as it merely hints, rather vaguely, at "the heart of Mecca" (bațn al-Makka) ${ }^{3}$. In another verse (Q 3:96), the commentators identify the term "Bakka"4 with Mecca. Similarly, the Qur'ānic use of al-madinna (Q 9:101, 9:120, 33:60, and 63:8) "is too general to assume that it is a proper name" (Reynolds 2010a, 199n713), while Yathrib is never mentioned-a lack that is comparable to many other locations in which Biblical or Qur'ānic events are assumed to have taken place. Reynolds (2010a, 199) mentions the lack of Uhūd, Țā'if, Arabia, Egypt, Yemen, Persia, and the Red Sea. Muhammad's hijra, his move from Mecca to Yathrib/Medina, which represents a crucial event for the early Muslim community and is held to have taken place in 622 CE, is also not mentioned in the Qur'ān. Jerusalem, which was later called the third holy city of Islam, is also missing in the Qur'ān, although the "further mosque" mentioned in verse 17:15 is traditionally understood as describing the Prophet's "night journey" from Mecca to Jerusalem. Yet the designations for Mecca ("the holy mosque,"

3 Q 48:24: "And it is He who restrained their hands from you and your hands from them in the hollow of Mecca after that He made you victors over them."

4 Q 3:96: "The first House established for the people was that at Bekka (...)." For a different etymology deriving Bakka from "the vale of tears," as mentioned in Psalm 84: 6-7, see for example Groß (2014, 890f.).

5 Q 17:1: “Glory be to Him, who took His Servant by night from the Holy Mosque to the Further Mosque (...)." 
al-masjid al-haram) and Jerusalem ("the further mosque," al-masjid al-aqșā) are open to interpretation, if one puts aside sìra and tafsìr literature for a moment. In other cases, the reference point of Qur'ānic expressions is also unclear. The word ka'ba, for example, is only mentioned two times (Q 5:95, 5:97), but not explicitly in connection with the hajj (pilgrimage) or the qibla (direction of prayer). Muslim commentators refer expressions like bayt (house), maqām Ibrāhīm (site of Ibrahim), and al-masjid al-ḥaram to the place of worship in Mecca. However, with regard to the pilgrimage, the Qur'ān simply directs people to "the house" (Q 3:97). The qibla is advised as the direction of prayers with the order to "turn your face to al-Masjid al-Haram" (Q 2:144), although at the time of the change of the qibla from Jerusalem to Mecca-according to Islamic tradition, in the year 623/24-the later mosque was still a place of pagan worship. The term mihrāb, which is later used to describe the concave niche in the wall of a mosque, which indicates the prayer direction (to Mecca), means something else ("temple") in the Qur'ān and early Umayyad texts, has an unclear etymology, and appears as a prayer niche in the early eighth century, according to Muslim historians (Khoury 1998).

A similar Qur'ānic silence holds true for the main protagonists of early Islam who are attested in sìra accounts, like "the Prophet's wives Khadija and 'A''isha, (...) his daughter Fāțima, his uncle Abū Ṭālib, his cousin 'Alī, or his companions Abū Bakr, 'Umar, and 'Uthmān" (Reynolds 2010a, 199). The Byzantines and the ruling Meccan tribe of the Quraysh are also only mentioned once in passing, without giving any details (ibid.). On top of that, the Qur'ān gives next to no biographical details about Muhammad. One can even argue that "the Qur'ān never identifies the speaker or the intended audience" (Reynolds 2010a, 15) of its message, even when it directly addresses this speaker or his community and uses different names, epithets, or titles for him. While the Qur'ān abounds with references to a messenger (rasūl) or prophet (nabī), Muhammad only appears four times (Q 3:144, 33:40, 47:2, and 48:29), while Abraham, Moses, and Jesus are named 69, 136, and 25 times, respectively; even Mary appears 70 times, more than three times as often as in the Gospels. Against this backdrop, the Islamic tradition-as expounded, for example, by Ibn al-Jawzī (d. 1200)—suggests that the Prophet had up to 23 (or even more) names, titles, or epithets, among them muhammad ("the praisedone"), ahmad ("the most-praised one"), and al-amin ("the reliable") (Reynolds 2010a, 193). However, it remains unclear whether muhammad is a proper name or a title. The four times a muhammad is mentioned in the Qur'ān, the verses refer to his vocation as the messenger of God, which could also refer to other messengers, like Jesus, whereas when "a messenger to come after me" is announced in the words of Jesus (Q 61:6), he is called Ahmad.

The historical, biographical, and geographical context of the Qur'ān is mainly added by later hagiographic and exegetical literature. In the Islamic tradition, the Qur'ān is so 
densely inter-connected with sirra and tafsir works that each genre helps to explain the lacunae of the other. In the traditional process of interpretation, Qur'ānic verses, which were revealed to the Prophet step by step, are not only connected with the events of his biography, but their meaning is also explained with reference to these events. In this sense, the Qur'ān acts as proof of Muhammad's life, while Muḥammad's deeds are a reflection of the Qur'ān. Insofar as it is difficult to distinguish religious legends from historical facts, not only John Burton's $(1993,271)$ remark that "exegesis aspiring to become history, [sic] gave us sira" is worthy of consideration. Beyond this, the more fundamental question is whether sira and tafsir literature works by reading meaning into Qur'ānic verses rather than by reading meaning out of them. The fact that the Qur'ān is closely connected with reports about Muhammad's life, composed much later, gives the impression that this kind of understanding of the Qur'ānic message comes closer to eisegesis than exegesis (Bangert 2016, 10).

The eldest testimonies of Qur'ānic verses were identified in the Dome of Rock in $692 \mathrm{CE}$, on Arabic coins from the time of caliph 'Abdalmalik (r. 685-705), attributed to 692 and 697/98 CE, and as tombstone inscriptions from Egypt, attributed to $691 \mathrm{CE}$ (Bacharach/Anwar 2012). The collection and redaction of the Qur'ān under the caliph 'Uthmān b. 'Affān (r. 644-656) resulted in the so-called rasm 'Uthmāni in the midseventh century, according to Muslim and mainstream academic scholarship. Under the reign of caliph 'Abdalmalik, an orthographic reform was implemented which introduced diacritical dots for consonant homographs (Würsch 2013, 34f.). The introduction of vowels for words with different spelling possibilities happened by the end of eighth century. While the Islamic tradition knew different readings as well as some minor textual variants, the printed standard edition by Azhar University, from 1923/24, follows the reading of Kūfa (Hafṣ 'an 'Āṣim). Yet the underlying manuscripts of the Azhar edition are unknown, and several inconsistencies in the text have been highlighted (Puin 2011). It is also unclear whether the text really reflects the rasm 'Uthmānī. A critical reconstruction of the textus receptus, based on different existing Qur'ān manuscripts, is still missing (Gilliot 2006, 52), although the Berlin project Corpus Coranicum aims at compiling a historical-critical text edition of the Qur'ān (Würsch 2013, 28). Among Shī'i scholars, the idea of a "falsification of the Qur'ān" (taḥrīf al-Qur'ān) at the hands of Sunnī redactors who supposedly aimed to erase or belittle the role of 'Alī b. Abī Taalib (d. 661) was widespread up to the tenth century CE; although it subsequently lost its importance, it never totally vanished (Würsch 2013, 34; Brunner 2001). Muslim as well as non-Muslim scholars have occupied themselves with the question of misspellings (tașhîf) in the Qur'ānic text. The "dog" in the originally Christian legend of the Seven Sleepers (Qur'ān 18: 9-26) was recently identified as a possible candidate for such a misspelling (Würsch 2013, 35f.; Waldner 2008), since it is not existent in the original 
legend. Without diacritics, kalbuhum ("their dog") in verse 18:18 resembles the word kāli'uhum and could therefore have meant "their guard." Once fixed in the Qur'ān, the dog of the Seven Sleepers, however, came into his own in popular belief and book paintings and was even counted among the elected creatures who were promised Paradise (Würsch 2013, 36). Squeezing higher sense out of the presence of the dog in the Qur'ānic verse has proved quite challenging intellectually for Muslim interpreters as well as for academic scholars until recently (for some examples, see Koloska 2016, 438).

The Jewish and Christian presence in and around the pre-Islamic Arabian Peninsula is fairly well documented (e.g. Finster 2010; Berger 2016). Yet it is more difficult to ascertain what kind of Christians and Jews lived in the Hijāz. Lecker (1985; 1995a; 1995b; 2000; 2016; 2017), sifting through early Arabic literature, tried to figure out whether Muhammad had monotheistic, Christian, and Jewish relatives, whether Muslims and Jews possibly lived close to each other in Medina, and who the Jewish allies among the Arab tribes were. Jews are regularly mentioned in early Islamic sources, for example in the so-called constitution of Medina; yet the three tribes that were later to be expelled from Medina, according to the tradition, do not appear in the document (Donner 1998, 72f., 227-235; Lecker 2012). According to Islamic tradition, Muhammad himself ordered an icon with Mary and the Child to be preserved in the Ka'ba after the conquest of Mecca, which suggests that the Ka'ba might have played a role in Christian worship in pre-Islamic and early Islamic times (Rubin 1986, 102; Finster 2010, 83). The name of the Ka'ba itself refers to a cubic architectural body and might have been constructed according to examples of churches in Arabia or the dome at Debra Damo in Ethiopia (Finster 1991; 2010, 76) and seems to have been decorated with paintings and frescos (Finster 2010, 83).

\section{Revisionist Arguments}

Against the background of uncertainties and contradictions in the history of early Islam, revisionist and neo-revisionist scholarship-since Crone and Cook (1977) and, with new vigour, since the end of the 1990s-has started to question a growing amount of what these authors call the "assumptions" on which Islamic salvation history as well as traditional Orientalist scholarship is grounded. Challenging mainly the reliability of the earliest available Arabic accounts about the emergence of Islam, revisionist scholars try to disentangle the Qur'ān from the information given by Arab informants and draw, instead, from contemporary non-Arabic sources. In this sense, the scholars separate the Qur'ān and its traditional context from each other and try to reconstruct 
different relations between the Qur'ān and other-mainly Jewish or Christian-contexts. Revisionist scholars' doubts about the chronology of early Islam are accompanied by doubts about locations and spaces, traditionally connected with the emergence of Islam. These doubts involve the composition of the Qur'ān, the life of Muhammad, the role of Mecca, the Arab expansion, and the institutionalization of Islam. While early revisionist scholarship suggested a late composition of the Qur'ān in the ninth century (Wansbrough 1977, Burton 1977, for a critique: Schoeler 2010) and a strong imprint on early Islam by Jewish messianism (Crone/Cook 1977), the neo-revisionist tide has now turned to the possibly Christian antecedents of the Qur'ān and the supposed "Christology" of early Islam (Luxenberg 2004; Kerr 2014a and 2014b; Ohlig 2014). Thus, revisionist scholarship works both ways, suggesting an earlier dating for the Qur'ān and Islamic origins while at the same time proposing a later institutional formation of the Qur'ān and of Islam as we know it today.

Günter Lüling (1993) and Christoph Luxenberg (2004; 2005; 2007; 2008), for example, not only try to re-construct hymnal structures and the meaning of verses, words, and the mysterious letters in the Qur'ān by drawing from non-Arabic vocabulary, but they understand at least parts of the Qur'ān as an originally Christian liturgical text. Revisionist scholars have also suggested that muhammad should not be understood as a proper name, so that the part of the Islamic creed muhammadun rasūl allāh translates to "Praised be the messenger of God" (Luxenberg 2005; Puin 2014) and could thus refer to Jesus; a prophet of the name Muhammad might then be seen as literary fiction (Popp 2005). The presumably first Muslim inscriptions in the Dome of the Rock in Jerusalem, with their multiple references to Jesus, could, then, be understood not in the traditional sense as anti-Trinitarian and anti-Christian, but as an anti-Trinitarian yet still Christian writing. A further assertion is that early Umayyads, such as Mu'āwiya b. Abī Sufyān (ruled 661-680 CE), actually were Christians, which is reflected in their use and mintage of coins with Byzantine symbols-a fact revisionists interpret as proof of the existence of a Christology (Popp 2005; for a critique: Heidemann 2007 and 2010).

A recent radiocarbon dating of parchment fragments from old, incomplete Qur'ān manuscripts-one held by Birmingham University, the other stemming from Sanaa, held at the University of Saarland-also added to the discussion about Islamic origins, because the analyses have yielded different results with rather early-or even "too early" (Reynolds 2015) - dates. One folio was dated to 568-645, another to 433-599, when the Prophet, according to Islamic tradition, had not yet received God's message, and a third one was given a 75 percent likelihood of being older than $646 .{ }^{6}$ All these findings stand in contrast to Muslim historiography, which holds that a committee

6 The carbo-dating indicates the time of death of the slaughtered animal that was used to produce the parchment, not the time of writing. 
finished the redaction process for the first official manuscript of the Qur'ān during the caliphate of 'Uthmān (r. 644-656 CE).

Revisionist scholarship has also put Mecca-a name sparsely mentioned in the Qur'ān-as the birthplace of Islam into question. There has been a widespread scholarly consensus for more than 300 years, also corroborated by early Arabic sources, that Mecca was a place of worship in pre-Islamic times already. Claudius Ptolemy, a Greek writer from the second century CE, mentioned several places on the Arabian Peninsula which were later identified with pre-Islamic Mecca, among them a place transcribed as Macoraba. As Morris $(2018,12)$ recently pointed out, the first scholar who identified Macoraba with ancient Mecca was the Huguenot pastor and Orientalist Samuel Bochart (d. 1667) from Caen, in his Sacred Geography (1646); neither Late Antique nor Arab nor Medieval scholars had ever done so. The background of the concerted efforts of humanists and theologians to find ancient Mecca, which started in the 1530s, was that they tried, with the help of recovered Greek and Latin sources, to reconcile the geography of Mecca with a Biblical genealogy of Islam (ibid., 10). Over time, Bochart's thesis gained almost universal acceptance, and although it triggered a myriad of etymological explanations, ${ }^{7}$ it turned into a truism in religious studies, holding that Mecca was a centre of worship and trade before Islam, as mentioned by Ptolemy (see, for example, Eliade 1985, 63f.). Patricia Crone (1987, 134-137) challenged this consensus by noting that Macoraba lay in the wrong place and its etymologies were implausible, while none of the Late Antique sources at hand referred to Mecca nor to the Quraysh (see also Morris 2018, 35f. and 42f.). Crone's scepticism not only severed the link between Macoraba and Mecca, but cast general doubt on the assumption that Mecca was a major node on the incense route (Crone 1987 and 2005; for a critique, see Bukharin 2010). In other words, not only did Macoraba lie in the wrong place (for being Mecca), but so did Mecca (for being the birthplace of Islam). Since Crone's intervention, the economic, philological, and architectural arguments put forward against Mecca as the birthplace of Islam concern the lacking importance or virtual absence of preIslamic Mecca on the Arabian Peninsula in pre-Islamic and non-Islamic sources before the mid-eighth century. Revisionist authors also draw on the Qur’ānic Arabic "dialect," which would better fit Syria, or they argue with the mihrābs of early mosques, which point to different directions and only began pointing to Mecca in the eighth century (e.g. Crone 1987; Kerr 2014a; Gibson 2011). Thus, the emergence of Islam is said to

7 Morris $(2018,41)$ sums up: “Macoraba has been variously decoded as a great battlefield, great Mecca, Mecca of the Arabs, city of the Malik, city of the Harb, city of the West, valley of the Lord, house of the Lord, a place of sacrifice, a place that brings us closer to the gods, and a temple; derived from Arabic, Syria, Aramaic, Ethiopic, Phoenician, Akkadian, Hebrew, and Ancient South Arabian." 
have most probably occurred not in a "barren place" (Crone 1987, 6f.) like Mecca, but farther to the North, beyond the peninsula, in Petra, Gaza, Syria, Mesopotamia, or even in Merw in the eastern part of the Persian Empire (Hawting 1999; Gibson 2011; Crone 1987; Nevo /Koren 2003; Kerr 2014a, Ohlig 2009). What unites revisionist scholars is their doubt regarding the Hijāzì origins of early Islam. They suggest that traditions that refer back to early Islamic Mecca were possibly fabricated in 'Abbāsid times to give an Hijāzī orientation to events that probably took place outside it; and they conclude, from indirect evidence, that "the notion of an early Meccan framework cannot be attested before the first half of the second [Muslim] century" (Ibn Warraq 2007, 225, quoting Bashear 1989, 232). Such a fabrication thesis holds that the centre of the origins of Islam was relocated (from an unknown place) to Mecca after a period of 150 years.

A further argument which follows from these revisionist approaches is that the Arab-Islamic expansion from the Arabian Peninsula to Andalusia, Central Asia, and India, from the first third of the seventh up to the mid-eighth century, did not happen by military force but mainly peacefully. The indirect argument is that most of the adventurous and heroic deeds depicted in the Arabic accounts of the genre of futūhāt ("conquests") literature were more or less fabricated and lack archaeological evidence (Nevo/Koren 2003; Donner 2010, 106-144; Bangert 2016, 86-89, 530-535, 746).

In this respect, a further argument holds that the Oriental Christian dissenters of the Council of Chalcedon (451 CE), the Nestorians and Monophysites, welcomed Muslim rule because all of them agreed on the human nature of Jesus and thus preserved an anti-Trinitarian and Jewish form of Christianity against an emerging Greek dogmatism. The Council of Chalcedon had fixed the Trinitarian dogma and ruled that the divine nature of Jesus Christ was united with His fully human nature "unconfusedly, unchangeably, indivisibly, inseparably" (Bindley 1899, 226). The Christian disunity in the Byzantine Empire helped the Persian and Zoroastrian Sassanids, who tolerated Oriental Christians, to conquer Jerusalem, Damascus, Egypt, and parts of Anatolia and Armenia at the beginning of the seventh century. Therefore, this narrative suggests that the emperor of Constantinople might have given up on Oriental Christians and ceded the Near East to his former (Christian) Arab allies. A further suggestion in this context is that the hijra calendar, whose beginning is dated to 622 , has nothing to do with Muhammad's emigration from Mecca to Medina, but with the beginning of Emperor Heraclius' counter-offensive against the Sassanid Empire. To summarize, most of what the Muslim sources recount about the early history of Islam seems to be a forgery from 'Abbāsid times in this view' (for an overview see Bangert 2016).

8 Donner $(1998,26-28)$ has succinctly objected to the "radically sceptical" assumption of a "forgery" with the argument that it leaves open the question of how such a forgery could have happened, 
Revisionist scholarship does not build up a comprehensive alternative theory for the emergence of Islam; it rather experiments with different approaches that question established chronologies, locations, and narratives of early Islam in contradistinction to traditional Muslim and non-Muslim scholarship. The mistrust of early Arabic sources leads to a deconstructive reading of early Arab accounts and later Orientalist reconstructions, which, for example, leads to post-dating Muhammad's death and thus changing the chronology of the events in early Islam (Shoemaker 2012). Such attempts to reorganize the early history of Islam according to an alternative reading of sources are enmeshed in vague evidence. It is a kind of a paradox that revisionists cast doubt on the writings of Muslims from the second and third centuries $\mathrm{AH}^{9}$ because they were as far from Muhammad's as we are from Napoleon's times today, while they try to convince us that their own speculations, 1400 years after the events, are scientifically and linguistically more trustworthy.

As there are hardly any sources available for the first 150 years $\mathrm{AH}$, it is certainly true that we actually cannot know much about the historical Muhammad, although "we probably know more about Mohammed than we do about Jesus (let alone Moses or the Buddha)" (Crone 2008). Since the historical reliability of Muslim sources, mostly written after $750 \mathrm{CE}$, is doubtful, it is nearly impossible to extract historical kernels of truth in reports about the life of Muhammad. In spite of questioning the value of these sources altogether, an alternative scholarly approach therefore tries to determine which traditions about a certain event are the earliest, with the intention to reconstruct the genesis of the corpus of Islamic tradition (e.g. Motzki 2000). Yet as radical sceptics neither accept nor practice this approach, the approach and its results have become part of a scholarly debate about methodological questions (Shoemaker 2011; Görke et al. 2012; Görke/Motzki 2014; Schoeler 2014).

\section{Critique of Revisionist and Mainstream Arguments}

In spite of its bold assertions, (neo-)revisionist scholarship has not solved the fundamental uncertainties in studies about the emergence of Islam and is, in this respect, surprisingly similar to conventional scholarship, which it so severely criticizes. Revisionist scholarship is based on at least three problematic assumptions that it has not overcome to this day. Firstly, casting doubt on the traditional chronology of the history of early Islam-post-dating or pre-dating certain events and constructing

given the lack of agreement among early Muslims, the lack of a central normative authority, and the lack of a supervisory body that must have controlled and changed the sources from a vast area. 
a different historical context-is certainly a useful scholarly challenge; however, revisionist scholarship has not given birth to a convincing alternative chronology for early Islamic events. Secondly, insofar as revisionist scholarship indulges in a radical reinterpretation of Qur'ānic texts and early Arabic inscriptions by re-constructing relations to non-Arabic sources and terms, it remains a philological exercise producing thoughtprovoking insights. Yet as we know next to nothing about the social, religious, and ritual practices during the first century after Muhammad's presumed death in 632-if we put aside the Arabic texts produced another century later-, then these speculations rest on thin ice. Especially meagre is evidence for the idea that early Muslims understood themselves as Jewish or anti-Trinitarian Christians or a combination of both and read liturgical texts of Christian origin that were only later adjusted to the Islamic Qur'ān; or that the people who adjusted and punctuated the text misread or misunderstood most of it, whether intentionally or unintentionally. Thirdly, re-reading the Qur'ān with a more comprehensive (not exclusively Arabic) philological toolbox is obviously worthwhile, but it has so far only led to the creative re-construction of Christian textual layers beneath the Qur'ānic text-by changing the punctuation of Arabic letters or creating new meanings of Qur'ānic terms with the help of non-Arabic vocabulary. However, an "Urkoran" (Lüling 1993), the hymnal or liturgical text (possibly) in Syro-Aramaic on which the textus receptus of the Qur'ān (or parts of it) is presumably based has not been detected. In contrast, the statement still holds that “the Qur'an is not borrowing or retelling the Biblical story, but rather commenting on it" (Reynolds 2010b, 585). Griffith (2013a; 2013b), who has tried to determine when the Bible became an Arabic scripture, has shown that "the Bible is at the same time everywhere and nowhere in the Arabic Qur'ān; there are but one or two instances of actual quotation" (Griffith 2013a, 2). While the number of what counts as actual quotations from the Bible is certainly debatable, there is a consensus that Biblical material must have circulated orally in Arabic at first; written translations into Arabic were made by Christians and Jews outside of Arabia, and only after the Arab conquests (Griffith 2013, 3). ${ }^{10}$ This suggests that the codification of the Qur'ān initiated or pushed the translation of the Arabic Bible.

The whole debate about the "dark origins" of Islam with its two opposing camps and their sometimes polemical tone-represented by the so-called Saarbrücken school and the Inârah Institute around Karl-Heinz Ohlig, Gerd-R. Puin, and Luxenberg, on

10 According to Griffith $(2013,3)$, "Christians had written scriptures in Arabic from at least the middle of the eighth century and possibly earlier; by the ninth century Jews too were translating portions of the Bible into Judaeo-Arabic, if not somewhat earlier. Christians translated from Greek or Syriac versions; Jews translated from the original Hebrew. It is not clear where these early translations were made; the available evidence suggests that in the Christian instance the monasteries of Palestine, where most of the early manuscripts have been preserved, were also the locations of the translations." 
the one hand, and the Corpus Coranicum group in Berlin around Angelika Neuwirth, on the other hand-cannot be dealt with in further detail here. For the purpose of our discussion on the emplacement of (early) Islam, it is, however, important to note that authors from the opposing camps create different spatial contexts in their textcentric approaches for a more or less context-less Qur'ān and construct causality via chronology. This creates several problems visible in (1) the concept of Late Antiquity; (2) the container understanding of space; (3) the quest for historical kernels of truth in literature or space; (4) the attribution of genealogical and exegetical meaning to Mecca and Medina in Qur'ānic studies; (5) the geographies of Jewish and Christian influences; (6) the question of the in/stability of Islam resulting from internal divisions and its rapid spread; and (7) the search for the Christian roots of anti-Trinitarianism.

(1) While a consensus seems to exist that it is important to locate the emergence of Islam in the context of "Late Antiquity" (Brown 1971 and 1978; Fowden 2015 and 2016; Schmidt et al. 2016a; Shoemaker 2014), this historiographical term is employed to mark different spaces and elaborate different explanations. The historian Garth Fowden $(2015 ; 2016)$ uses the first millennium as a periodization that allows drawing broad strokes of the history of Islam-emergence, development, maturity-and integrating it into a general history of Euro-Asia by shifting the focus away from the Mediterranean to the East. In contrast, research on the origins of Islam and on the Qur'ān (e.g. Neuwirth 2010a; Neuwirth et al. 2010) has a much narrower understanding of Late Antiquity. Here, the term is delineated as a primarily virtual "thinking space" (Schmidt et al. 2016a), which helps to grasp the transformation processes in Late Antique thought as well as the transfer of biblical, post-biblical, philosophical, and Jewish knowledge to the Arab space (Schmidt et al. 2016b, 21). Situating early Islam in a transcultural context called Late Antiquity thus helps to fill the blank of the first Islamic century with different-mainstream and revisionist-agendas. While both camps try to explain the Qur'ānic entanglement with biblical material-the "Biblical subtext" (Reynolds 2010a) of the Qur'ān—, they envision the impact of Judaism and Christianity differently (see also (4)). In a paradoxical turn, the Late Antique contextualization of Qur'ānic studies prioritizes a focus on similarities, entanglement, and parallels with Judaism and Christianity; yet both mainstream and revisionist scholarship proposes that the Qur'ān either actively reworked or altered the Jewish and Christian impact. In consequence, mainstream scholars tend to see early Islam as an already stable entity, thus underlining the non-epigonic singularity of Islam's unique treatment of biblical motives and downplaying inter-religious parallels. Revisionist scholars cherish the idea that early Islam was a rather unstable and weak entity, yet strong enough to alter, if not falsify, biblical motives. Beyond this, neither the temporal nor the spatial boundaries of the Late Antique contextualization of the Qur'ān are clear. Interestingly 
enough, Neuwirth (2010a) announces her study, entitled the "Qur'ān in Late Antiquity," as a "European approach" in the subtitle. This example is disturbing insofar as it blurs the boundary Islam/Europe in the title, but re-erects it in the subtitle. It aims to move the history of Islam closer to late antique Europe, yet distances the academic study of the Qur'ān from a non-European perspective. Not making these differences visible is questionable; spatializing them, however, suggests that the history of Islam in Late Antiquity is located in a "thinking space" transgressing boundaries, whereas its study requires taking sides.

(2) The revisionist approach questions the importance of Mecca/Medina as the places of revelations and takes them for literary fiction and a later construction (e.g. Kerr 2014a; 2014b). Mainstream scholarship clings to the traditional differentiation, going back to Theodor Nöldeke (d. 1930), that distinguishes three phases of Meccan revelations from Medinan Sūras and attributes meaning to this emplacement of the Sūras (see Nöldeke 1970 and (4)). In both cases, a container understanding of space is dominant, according to which early Islam spread from smaller to bigger containers. In the first case, Islam moves from Mecca to Medina, subduing the Arabian Peninsula, then Mesopotamia, and so forth (e.g. Berger 2016). In the revisionist case, a deconstructivist mode radically questions the starting-point and simply plays with the idea of putting early Muslims in another location, from where they spread. From the technical side, this is reminiscent of Kamal Salibi's reverse attempt (1985; for a critique: Beeston 1988), in which he used place names of the Hebrew Bible and epigraphic evidence to locate ancient Jewish history in the Hijāz and 'Asīr, arguing that there was a severe mismatch between Jewish stories and archaeological findings in Palestine, while the names made perfect sense in Arabia.

(3) Mainstream and revisionist scholars share the desire to distinguish kernels of historical truth from fabricated traditions. The paradox in this respect is that revisionist scholarship generally opposes mainstream approaches that try to separate the "real" kernels from the fictious parts of early Islamic literature; yet it proceeds in the selfsame way by trying to identify the original place of the origins of Islam and distinguish it from the fabricated one (i.e. "Mecca").

(4) The mainstream approach, which departs from a refined differentiation between Meccan and Medinan Sūras (e.g. Neuwirth 2010a), ascribes exegetical meaning to space. This differentiation is based on the different styles of the Sūras, although Meccan and Medinan verses have also been inserted to otherwise named Sūras, and the Fātiḥa (Qur'ān 1) is even understood as both a Meccan and Medinan Sūra (Bobzin 2010, 603n10). Moreover, Neuwirth's (2010a, 2010b) main view is that the composition of the Qur'ān reveals a dialogical character. However, the assumption that the Qur'ān expresses a "dialogue" between Muhammad and his community and that 
its oral composition preceded the written one is based on a textual interpretation that presupposes a causality as well as social practice in Mecca and Medina for which there seems to be little empirical evidence (for a polemical critique, see Groß 2014, 803-931).

For example, Neuwirth interprets the Qur'annic references to the story of Abraham as different "lectures" in Mecca and "re-lectures" in Medina and thus tries to corroborate a chronology of the Qur'ānic text as well as a chronology of an inner-Qur'ānic reinterpretation (Neuwirth 2016, 191-196; also Sinai 2009). The relevant verses stem from the Sūras 2, 3, 14, 21, 37, 52, 53, 57, and 87. Neuwirth (2016) holds that these verses actually reflect dialogues that really took place "in" Mecca or Medina. She holds that the re-lecture of Abraham's story in Medina finally managed to localize Abraham's sacrifice in the Ka'ba and in Mecca. Neuwirth's view creates problems on the spatial and textual level. In the first step, Neuwirth (2016) does not differentiate between the physical-historical space in which a dialogue takes place and the symbolic ascription of spatial markers to Sūras; spatial markers that are otherwise missing in the Qur'ānic text were later introduced for the Sūras and mainly follow from a stylistic analysis or from the literature of "occasions of revelation" (asbāb al-nuzūl) of later centuries. In a second step, the text-immanent ascription of space to different parts of the text is used to establish a historical chronology of the textual genesis. In a third step, the relecture in physical Medina expresses an exegetical development; this development is reflected in the location of Abraham's story in pre-Islamic Mecca, which is said to have caused the establishment of new hajj rites in Mecca when the Prophet was in Medina, although the Qur'ānic text does not mention either Mecca or the Ka'ba explicitly in this context, while hajj rites and their alteration by Muhammad are also mentioned in the traditional literature for the pre-Medinan time.

The circular reasoning in three steps amalgamates the genesis and exegesis of the text as well as the physical and symbolic dimensions of space. Although Qur'ānic verses are characterized by different styles, and their revelation is spatialized in the Islamic tradition as well as in the Orientalist approach following Nöldecke, it might still be possible and useful to differentiate between the symbolic ascription of space to verses and the physical location of their revelation or, in other words, between the styles of the written Qur'ānic text and the "dialogues" of believers. Although a chronological ordering of the verses which make up the story of Abraham along the axis of Meccan and Medinan revelations is not implausible, certain requirements result: the style of the revealed verses must correlate with their chronology; the chronology of the revealed verses must constitute a causal connection; the written verses must give a complete picture of the oral lectures and dialogues so that the "re-lecture" in Medina adds something to the "dialogues" that have already taken place in Mecca; the community must have been aware of the links between dialogues held at different times; believers 
must have understood these links and adopted a new rite; in spite of these links, the relevant verses were later allocated in scattered places in the textual corpus of the Qur'ān; this scattering of chronologically and causally linked verses in the Qur'ān was possible because the believers either knew or did not know the links; the exegetical literature re-affirmed the previously existing links; and today's scholarly reconstruction of these links does not create an illusionary chronology or causality.

(5) The different geographies of the opposing camps often induce an emphasis on different "influences": one side implicitly underlines Jewish influences, while the other often stresses Christian ones. The strategy to downplay Christian influences by highlighting Jewish ones-thus opposing the revisionist thesis of a Syro-Aramaic lexis (Luxenberg 2004) and a vernacular poesy (Lüling 1993) in the Qur'ān-seems problematic. When Sinai/Neuwirth $(2010,19)$ argue that the Psalms are "the only biblical corpus that has exerted a formative impact" on the theological and literary shape of the Qur'ān, this assumption entails a formal and a spatial problem.

On the formal level, the focus on Islamic-Jewish similarity downplays the homiletic quality of the Qur'ān. Reynolds (2010a, 243-258), who is not convinced by Neuwirth's parallelization of the Qur'ān and Pslams, speaks out in favour of sorting the Qur'ān into the larger homiletic tradition because of its insistence of not delivering a new message (Qur'ān 3:3, 5:48), its permanent allusions to biblical material, and its topical wandering. The apparent random character and the seemingly arbitrary organization of the Qur'ān can thus be explained as a structural trait and a reflection of the Syriac homiletic tradition. Reynolds $(2010 a, 254)$ argues that our understanding would gain much from reading the Qur'ān's unique treatment of biblical motives as well as the Qur'ān's biblical subtext in the light of a homiletic tradition, and that "the Qur'ān itself points us to this reading."

The spatial problem lies in the fact that our knowledge of the history of Jewish and Christian practices and doctrines in the Hijāz is rather limited. Mazuz (2014), for example, has tried to discover the religiously and spiritually "authentic" life of Jews in Medina by indirect evidence drawn from early Arabic sources; he concludes that most Jews were "Talmudic-Rabbinic Jews in almost every respect" (ibid., 99). This remains speculative because the "customs, laws, practices, and beliefs of the Medinan Jews are essentially constructed in absentia" (Hughes 2015, 581). Thus, the question arises of why "it was so important to Mazuz that the Jews of Medina be normative" (ibid., 582). On the one hand, Mazuz creates "a continual and 'authentic' Jewish identity that stretches out from the ashes of the destruction of the First Temple and moves directly through to the codifiers of the Babylonian Talmud (and beyond)" (ibid.). On the other hand, Mazuz supports the suggestion that "since Muhammad did not have access to the Talmud, the Jews of Medina function metonymically for Talmudic law" (ibid.). In this 
sense, the Muslim community's "dialogue" (Neuwirth) could also involve Talmudic Jews and thus their texts, no matter whether this dialogue found expression in Meccan or Medinan Sūras.

Characterizing Meccan parts of the Qur'ān as "hymns" that "sound like distant echoes of the Psalms" (Neuwirth 2010b, 735) might, however, not only overstate similarity and neglect differences (Sanni 2015, 310); it also envisions the echo "in" Mecca before a possible dialogue with Mazuz's "Talmudic Jews" "in" Medina could have taken place. In this respect, it seems that Neuwirth lumps together the spatial and temporal differences in the term of a "distant echo", whereas in other instances, a painstaking differentiation between physical Mecca and Medina extracts symbolical meaning from a probable sequence of events at these places (see (4) above). Would it go beyond the scope of a geographical location of the revelation in Mecca/Medina if the echo of the Psalms stemmed from Yemen or from beyond the Arabian Peninsula? Another possibility of explaining the source of a Jewish echo in Mecca is to fall back on the speculations of the outsiders Dozy (1864) and Lüling (1985; 2000). Dozy (1864) argued that the Simeonite tribe of Israel had defeated a part of the Canaanites in an unidentified town called Hormah, which Dozy related to the sanctuary at pre-Islamic Mecca. According to him, the Simeonites had conquered the land in which Mecca would emerge, and they were called Ishmaelites in the sense of "immigrants" (see Morris 2018, 25). Lüling (1985; 2000) further elaborated Dozy's thesis by arguing that the cult in pre-Islamic Mecca was controlled by Levite emigrants after the Jewish conquest (Morris 2018, 27). Both authors' narratives try to explain parallels between Muslim and Israelite rituals "as the residues of an Israelite conquest" (ibid., 25).

(6) The different revisionist and mainstream emplacements of early Islam show that the entanglement of Judaism and Christianity with early Islam-and the contradictory negotiation of these relations in the Qur'ān-still forms a fundamental challenge in the studies on the origins of Islam. The multi-religious landscape of Arabia is mainly spelled out as having varied impact on or commonalities with Islam, rather than as a panorama of doing and undoing differences. Since entanglement has been a recurrent topic in religious polemics as well as in scholarship throughout the centuries, mainstream as well as revisionist scholarship actually navigates known waters by stressing the close relationship of the three religious traditions, yet re-writes their entanglement in different ways. Mainstream scholarship-especially in Neuwirth's case, discussed above-tends to view Islam as a stable entity from early on, while revisionist scholars place Islam more clearly in terms of dependency on Christianity and Judaism, which finds its expression also in moving the location of Islamic inception to distant (or nearer?) places. The revisionist idea that "Islam is little more than the sum of earlier monotheistic parts" (Hughes 2017, 871) is part of a lasting discussion on the origins of 
Islam by non-Muslims and Orientalists. The problem with this idea is not only that it suggests that the Qur'ān and Islam are epigonic, but that it assumes "that Judaism and Christianity were somehow more stable than what was gradually coalescing into Islam" (ibid.). Neuwirth's insistence that the Qur'ān is not epigonic (in spite of its diverse borrowings) and that it possesses a full-fledged theological concept (which requires complex re-constructions of the text) treats Islam as an entity as stable as the other two traditions-in spite of multiple internal divisions, which were a subject of conflict in the first century $\mathrm{AH}$, according to Islamic tradition.

Even Donner's (2010) proposal, which sees early Islam as an ecumenical movement and tries to bridge the gap between revisionist and mainstream scholarship, follows the same paradoxical trajectory. It holds that early Islam began as a movement of "believers" (mu'minūn), including "pious Christians and Jews" (ibid., 171), and gradually transformed into a group of clearly distinct muslimūn. It is not only possible that this proposal describes "a tolerant world that may not have existed" (Crone 2010). It also nurtures the suspicion that it blurs the boundaries between (Islamic) discourse and reality (Zelletin 2016, 128). Generally, Donner's study is based on two important distinctions. He understands early Islam as a religious movement rather than an economic, social, Arab, or political one-as most of revisionist scholarship might prefer to do-, and he envisions how rather stable forms of Judaism and Christianity "gave birth to an unstable Islam," as Hughes $(2017,882)$ put it. The first problem with this proposal is that we do not know much about "either the contours or contents of Christianity or Judaism, in large part because we have very little idea of what any of these three 'religions' would have looked like at that particular time and in that particular location" (Hughes 2017, 882). The second problem is that unstable Islam-riven by two civil wars and rivalling groups in its first century-was strong enough to rapidly conquer vast parts of Christian Byzantium and all of Zoroastrian Persia because of their military exhaustion and lacking social cohesion due to internal religious diversity and strife. This paradox remains a main challange in the historiography of early Islam (see also Berger 2016).

(7) With regard to pre-Islamic Arab Christians in and around the Arabian Peninsula, ${ }^{11}$ the generally accepted wisdom today is that they might have been heretical groups after the Council of Chalcedon (451 CE), which built and maintained churches and monasteries at several places on the peninsula (Finster 2010, 70-75). Revisionist scholars tend to further assume that Muslims evolved from Judeo-Christians who opposed the Hellenization and rationalization of the Christian doctrine that became apparent with the dogmatic formulation of God's Trinity, which took shape between

11 This mainly refers to the Byzantine vassals, the Ghassanids, and the Sassanid vassals, the Lakhmids, who are associated with Monophysitism and Nestorianism, respectively. 
the First Council of Nicaea (325) and the Eleventh Council of Toledo (675). Against this background, there has been, among Western scholars, "a never-ending hunt for a particular Christian sect" (Reynolds 2009, 252) that could explain Islamic antiTrinitarianism, which-given the variety of Christian groups-often led to puzzlement.

Although the Qur'ān refuses the Trinity in several verses (Q 4:171, 5:73, 6:163, 17:111, 25:2, 37:35, 47:19, and 112:1-4) (see Bobzin 2015, 58-66) and often understands it as an expression of polytheism, scholars have often pointed at the Qur'ānic account of the crucifixion of Jesus, which is only mentioned in two verses (Q 4:157-158). ${ }^{12}$ Most of the Islamic tradition and most Western scholars of Islam take it for granted that the Qur'ān denies Jesus' death, assuming “that this denial reflects the influence of Christian docetism" (Reynolds 2009, 238). New approaches, however, suggest that the verses can be understood, in line with the prevalent Christian perspective, as denying neither his death nor his elevation by God (Reynolds 2009; Lawson 2009). By studying forty Qur'ān commentaries from the seventh to thirteenth centuries as well as modern exegetes, Lawson (2009) has tried to show Qur'ānic "neutrality" in this respect, arguing that it was tafsīr, not the Qur'ān, which denies the crucifixion of Jesus with different arguments. Most interpreters tried to make sense of shubbiha lahum ("it appeared to them"), a hapax legomenon in verse 4:158, by reading it as "what was seen crucified on the cross was just an image: a phantom, not the real Jesus or perhaps even a substitute" (Lawson 2009, 3). Reynolds $(2009,240)$ argues that the relevant Qur'ānic verses can be read in the sense of "God (and not the Jews!) first made Jesus die, and then made him ascend to heaven." Therefore, Reynolds $(2009,255)$ thinks that the Qur'ānic passage makes two points: First, it is about Jewish infidelity (since Jews killed Jesus just as they did other prophets) and, second, about God's control over life and death. In this sense, the Jews who claimed to have caused what appeared to them as the death of Jesus "are twice in error" (ibid.). Instead of establishing a main difference between Islam and Christianity, the passage rather seems to be in line with the mainstream of Christian anti-Jewish rhetoric (ibid., 255-258).

The Qur'ān's “neutrality"-as opposed to the bias in tafsir literature-might remain a question of debate (Shah 2010, 198), since the Islamic exegetical tradition also created the historical context for the Qur'ān, as Reynolds $(2009,252)$ admits. ${ }^{13}$ Given

12 "And their saying, 'We have killed the Messiah Jesus the son of Mary' the messenger of God. They did not kill him nor did they crucify him, rather, it only appeared so to them; in reality, those who differ about him clearly are in doubt concerning the [matter]: they have no knowledge of this save their conjecture. Certainly, he was not killed; but rather he was raised by God to Him; God is mighty and wise."

13 The Christian soteriology, which is connected with the life, death, and resurrection of Jesus, certainly marks a decisive difference to Islam and its soteriology (Khalil 2013). 
that this particular Qur'ānic passage does not directly express an anti-Trinitarian credo but was only interpreted as such, the claim that the Qur'ānic wording might reflect the credo of a particular Christian sect remains dubious, although Christian Monophysitism might have influenced its interpretation. Yet from a Jewish point of view, a nonTrinitarian understanding of God is not at all peculiar. Thus, the Qur'ānic passage about the Jewish treatment of Jesus can be understood as a way of establishing a difference to Jewish, not Christian, views. In any case, scholarly attempts to localize the origins of anti-Trinitarianism in a Christian sect indirectly address the question of Islam's originality. Behind the disproportionate attention to Islam's anti-Trinitarianism lurks no new insight, but the old idea of Islam as a Christian heresy, which reflects "tropes and stereotypes that have dominated Western Christian discourse about Muslims since the reception of John of Damascus' depiction of Islam as a heresy" (Ralston 2017, 756) (see further below).

\section{A Topological Approach}

In most scholarly approaches about early Islam, (geographical) space merely forms the more or less plausible background scenery of events and contacts; it does not establish a relational space, which comes into being through human action, imagination, and emotion. The absence of Mecca in pre-Islamic documents and maps is no proof for the fictionality of pre-Islamic and early Islamic Mecca or the improbability of the emergence of Paleo-Islam ${ }^{14}$ in Mecca; it is rather a hint at the fact that the emergent Islamic community produced Mecca and its growing importance in a historical process. From the point of view of spatiality, the obligation to explain a complex phenomenon such as the emergence of Islam exclusively by its rootedness in a singular location or at the crossroads of civilizations is void. The revisionist attempt to re-date and re-locate the origins of Islam is based on a conception of Mecca that is at the same time too narrow and too wide-similar to the inverse cherishing of the conventional idea that there was a Meccan and Medinan period of the Qur'ānic revelation. It is too narrow if it restricts the meaning of Mecca to its geographical boundaries, and too wide if it marks the emergence of such a variegated phenomenon that was later called Islam. On the one hand, Mecca is bigger than itself because it has historical, political, and symbolic extensions; like with all geographical sites, the question is what the term "Mecca" means and where it ends. On the other, the emergence of Islam is a multilayered process that transcends narrow geographical boundaries as well as a Meccan

14 The term was introduced and is used by Al-Azmeh (2014). 
period, however defined. If we understand origins as a rhizome (rather than roots) and locations as spaces characterized through movement, connection, and circulation (rather than as immobile places), then the topology of early Islam must be relegated neither to a barren place nor located at the crest of cross-fertilization. Instead, the space of early Islam can be understood as polycentric, dynamically changing, uneven, and hierarchically structured. Depending on whether the focus lies on political, economic, religious, historical, imaginary, or emotional dimensions, the term "Muslim space" induces different outlines, movements, perceptions, representations, and spatial practices.

The relative absence or presence of Mecca and Medina in different parts of Islamic culture and practice is due to different contexts and their history-with regard to the Qur'ān, sìra and tafsīr literature, cartography, qibla, and hajj. The following remarks are meant to underscore the obvious point that the "emergence" of Islam does not go back to "dark origins" and was not completed by the first century $\mathrm{AH}$, neither in a political or military nor in a doctrinal or cultural sense. Debating the origins of Islam only makes sense with the spatial and temporal extensions of Mecca and Medina in mind. Although we do not know much about early Islamic Mecca and Medina, what is certain is that these places changed decisively as their commemorative, representative, architectural, and physical landscapes were reworked in the course of time, maybe prior to and during the emergence of Islam, but certainly after it. The production of sanctity for these cities took winding and contradictory roads and was connected with a wide range of activities involving literary production, investment, organization, urban planning, and even destruction.

Following these considerations, I highlight nine aspects that are connected with the spatiality of early Islam: (1) the relative absence of space in the Qur'ānic message; (2) the emplacement of Muhammad's biography in the Western Arabian Peninsula; (3) the composition of the Qur'ān with extensions beyond the Arabian Peninsula; (4) the processes that created a highly symbolic and representational value of Mecca, Medina, and the Ka'ba; (5) the establishment of haram districts; (6) the connection between Islam's spatial expansion and Muslims' reorientation in time and space; (7) the position of Mecca in a web of places and routes; (8) the conquests, spread, and re-invention of Islam beyond the first century; and (9) the emergence of Islam as an object of global knowledge production.

(1) The nearly total absence of names and places in the Qur'ān can be seen as a fundamental theological concept. Whereas names and places attribute evidential value and conclusiveness to stories and narrations, the Qur'ān renounces this concept of affirming truth claims. It is rather concerned with the question of how one can discern that its message is God's revelation. In its self-referential style (Wild 2006), it 
comments on prophets and messengers but does not tell a straight story either about Muhammad's activities or about the course of the world since its creation.

(2) Both these aspects are dealt with in later biographical and historiographic works, in which Muhammad and Mecca/Medina are placed within the course of world history and treated as exceptional. Although these reports claim to depict historical events, the places mentioned in this kind of literature do not necessarily reflect geographical realities. As part of a salvation history, they emplace the revelation and link it with the actions of the Arab prophet as well as with prophetic time; therefore, they have high symbolic, imaginative, and emotional value. Although the geographical and symbolic dimensions of a place may be relatively independent, it is rather improbable that they are totally detached from each other, as revisionist scholarship assumes. A topological approach understands the production of space (Mecca) and its sacredness (Ka'ba) as two intertwined historical processes that mutually confirmed each other, but in relation to competing places and claims (see more below under (4)). Thus, on the one hand, the weight of the Meccan framework, which has imposed itself since the second century $\mathrm{AH}$, can simply be explained by the fact that the production of a Meccan centrality took some time (no matter where the exact (!) place of origins lies); an alternative explanation seems superfluous. On the other hand, not only do time and place work against each other in the resettlement thesis, but the historical, mythical, and symbolic dimensions of Mecca would have been torn apart at a certain stage and would only have merged at a later stage, without ever wholly mending the break. It seems highly improbable that (a) the different processes that produced the historical and symbolic dimensions of a place named Mecca were, at one point in time, suddenly interrupted, and that (b) we can again disentangle them today. Even given that archaeological excavations hinted at another historical "Mecca," such hints (c) would still have difficulties explaining how the location or relocation of the Ka'ba and the sira worked and (d) would be overshadowed by the symbolic weight of today's Mecca, that would stand in contrast to archaeological evidence from a forgotten place. The resettlement thesis-in the absence of excavations-therefore requires a higher amount of credo quia absurdum than the production of a pilgrimage site in a barren place.

(3) The question of historical authenticity is not only relevant for the sira, but also for the reports about the collection and codification of the Qur'ān (see e.g. Motzki 2001; Schoeler 2010). However, it seems clear that the geographic places of these events, which led to the creation of the Qur'àn as a book, is different from the way in which the Qur'ānic revelation is emplaced in sirra literature. Even according to the Islamic tradition, the collection and codification of Qur'ānic material took place under circumstances that point beyond the Hijāz. Thus, the collection was not restricted to Medina and Mecca under the caliphate of 'Uthmān, but famously included other 
collections by Ibn Mas'ūd, Ubayy, and Abū Mūsā in Kufa, Damascus, and Basra, among others (e.g. Reynolds 2010a, 208).

(4) Although the importance of Mecca and Medina stems from the fact that they represent central places in the traditional literature about the emergence of Islam, they are involved in early events in different ways and to different extents. Therefore, the important symbolic as well as representative role that Mecca and Medina came to play has been produced through a complicated historical process (Peters 1986; Munt 2014). By all accounts, Mecca and Medina have never been regarded unanimously as the single most important places of early Islam, nor the hub of the world. In the religious imaginary, they were part of a web of interconnected places and spaces. From a political point of view, the centre of Arab power moved from Medina to Damascus, Kufa, Harrān, and Baghdad in the first centuries. Mecca was no central place of political power, although the Meccan Quraysh dominated the fate of the early Muslim community; Ibn Zubayr's reign as anti-caliph in Mecca (r. 683-692) was but a short episode. Islamic geographers of the ninth and tenth centuries did not place Mecca but Baghdad in the central position; showing Mecca as the node of the world was a phenomenon beginning only in the late tenth century CE (Webb 2013, 9).

By then, the matter of the sacred hierarchy between Mecca, Medina, and Jerusalem was "far from closed" (Munt 2014, 189), although a Muslim majority unmistakably considered both Mecca and Medina holy places by the end of the Umayyad period (Peters 1994a, 107-154). However, some scholars rearranged the ranking of the three cities, while others put forward claims of sanctity for Damascus, Kufa, Baghdad, and other cities. According to one tradition, Muhammad's haram is located at Medina because he founded the first prayer room in his house there, while the building of the Ka'ba in Mecca is associated with Abraham (Webb 2013, 7f.). The establishment of a sacred space in Medina was, however, controversially debated among scholars, since the boundaries of the haram district were presumably altered or expanded after Muhammad's death; other scholars even questioned the very existence of a holy district in Medina and opposed its establishment (Behrens 2007, 211-226). At the same time, caliphs encouraged pilgrimage (ziyāra) to some sites in Medina although there was already an early scholarly debate about the permissibility of performing prayers at the Prophet's grave (ibid., 227-276). Although the later writings of scholars and historians filled Medina's sacred topography with places, it is questionable whether the landscape they wished to depict really matched the physical conditions (Munt 2014, 96). For antiShī'i Sunni scholars, who regularly frowned upon the local rulers in the Hijāz because of their Shiite leanings and connections (Ende 1997), the cosmological and symbolic meaning of Mecca and Medina was certainly always clearly distinguishable from the existing topography and the pro-Shīi inhabitants and tendencies of these places. 
The emergence of the Ka'ba and the sacred district in Mecca is even more complex. Although the Ka'ba seems to have existed already in pre-Islamic times, its founders, its establishment, and the cult practices are a riddle, and different theories connect it to paganism or Jewish and Christian forerunners (Peters 1986, 104-122; Hawting 1982; Busse 1993; Dozy 1864; Lüling 2000). From the ninth century CE onwards, Muslim historians introduced the idea that the original building of the Ka'ba went back not only to Abraham but to Adam, who also performed the first hajj (Webb 2013, 8-9), and even that the Ka'ba existed prior to God's creation (Antrim 2012, 43-48). Accordingly, after the expulsion from Paradise, Adam came down to earth in Mecca, where he met Eve, who had come over from India. The spatial significance of Mecca, which "lies on a blessed trajectory directly beneath the throne of God" (Webb 2013, 9), explains why God "sent down"15 Adam here and why pilgrims must circumambulate this place in parallel to the angels' praise of God.

Early Muslim accounts are rather outspoken about structural changes and a preIslamic "pagan" use of the Ka'ba (Rubin 1986), which allowed Muhammad to "restore" the original rites. Accordingly, the Quraysh rebuilt the sanctuary with the help of Muhammad before his prophethood and thereby re-discovered the well of Zamzam, a treasure, and swords (Wheeler 2006, 19-46). In a report, a Coptic craftsman is said to have directed the re-construction of the Ka'ba (Peters 1986, 111). The Quraysh are also said to have removed the Black Stone from its original place on a nearby hill and put it into the Ka'ba four years before Muhammad's first revelation (Rubin 1986, 120). The other sacred stone, maqām Ibrāhīm, showing an imprint of Abraham's foot according to Islamic tradition, was transferred, together with the Black Stone, and placed adjacent to the Ka'ba or inside it at various times, while it is placed inside the mosque today (ibid., 122f.). When Ibn Zubayr, the anti-caliph, declared his sovereignty, the Umayyads layed siege to Mecca and the Ka'ba was destroyed by fire. Ibn Zubayr, who claimed to have found Abraham's original founding stone, had the whole building destroyed and rebuilt with the intention to restore its Abrahamic condition. When the Umayyads retook the city, they destroyed the new structure and returned the Ka'ba to the form it had had when Muhammad and the Quraysh worshipped there (Peters 1986, 113). While the Ka'ba seems to have remained unaltered after that, the surrounding haram district became the object of enlargement and monumentalization. The extension of the haram and properties around it became "a prime object for a new aristocracy of Muslims" (Peters 1986, 114).

There is evidence that "the Ka'ba was not always the primary place of worship in Mecca" in pre-Islamic times (Rubin 1986, 118), and even less a central destination 
for pilgrims from the whole Peninsula. Thus, it seems that the rise of the Ka'ba and Mecca as the paramount sacred site and pilgrimage destination in Islamic times was "a gradual phenomenon" (Munt 2014, 189; c.f. Peters 1994a, 107-154). Although there is only sparse evidence of social and ritual practices in early Islamic centuries, we can assume that these practices changed over time. With regard to the hajj, the Umayyad and 'Abbasid caliphs tried to use it for the legitimization of their power and monopolized leading the hajj. Yet we also know that political opponents and some Sufis scorned the hajj rites. Most famously, the Qarmatians went as far as killing pilgrims at the Ka'ba, throwing their dead bodies in the well of Zamzam, and robbing the black stone in 930 CE. Pilgrimage, however, was certainly not yet a mass phenomenon. Later reports often mention the participation of religious scholars, princesses, and princes, while the appearance of rulers was seen as an exception (Möhring 1994). Even when the organisation of pilgrimage caravans became an elaborate and expansive operation, Mecca remained a small or modest-sized town before its massive expansion in the twentieth century. ${ }^{16}$ While traveller Johann Ludwig Burckhardt (d. 1817) estimated the number of Mecca's inhabitants at 30,000 and pilgrims at 90,000 in 1814, today's numbers have risen to 1.5 million inhabitants and approximately 3 million pilgrims. Due to heavy investment in infrastructure, and in accordance with a desacralizing view of the Islamic heritage, Saudi authorities have not only massively restructured Mecca and Medina, but also destroyed 300 historical sites in both towns during the last two decades alone, an estimated 95 percent of the ancient Meccan heritage (Botz-Bornstein 2015, 165).

The history of the cemetery of Baqī' in Medina clearly expresses different readings and arrangements of the sacred, of Islam, and of space (Bobeck 2018). As many ahl albayt and șahāba (relatives and companions of the Prophet) as well as four Imams, caliph 'Uthmān, and respected scholars of Islam are buried in Baqī', it has been a central place for Sunnī and Shi'ī visitors for centuries, respected and enlarged by Umayyad, 'Abbasid, Selcuk, Mamluk and Ottoman rulers. The Saudi-Wahhabi conquests, however, led to acts of desecration in 1806 and 1925/26 in which shrines and gravestones were destroyed. After the Ottoman re-conquest of the Hijāz in the nineteenth century, the shrines could be re-erected only temporarily. As Ende $(1997,318)$ has put it, "protests against the destructions at Baqi' in general and of the tombs of the Imams in particular have been leitmotiv of Shiite writings about Medina" since 1925. For the sacred geography of the Shī'a, whose emergence Haider (2011) described already for the Kūfa/Najaf of

16 Rainfall often flooded the centre and undermined its buildings (Peters 1986, 74). Its growth has been estimated from 40 acres in 661 CE to twice this size in the following century and 147 acres, around $0.6 \mathrm{~km}^{2}$, in the sixteenth century (Peters 1986, 66). Only since the 1920 s did the town grow from 1.5 to 850 square kilometres. 
the second century $\mathrm{AH}, \mathrm{Baqi}^{\top}{ }^{`}$ is not only an integral part of the collective memory, but also a central place in the web of interconnected shrines that leads believers to friendly sites and away from inimical zones. From a Wahhābī understanding, visiting a tomb conflicts with tawhïd (the unity of God), thus verging on idolatry and shirk (polytheism). To avoid the temptation of idolatry, Saudi-Wahhabi spatial practices aim at disrupting the relation between the living and the dead (Bobeck 2018,6). Not only the practices in Baqī are strictly controlled today; Wahhabi scholars still discuss the destruction of the so-called Green Dome (al-qubba al-khadrā'), erected by the Mamluks in 1279 CE over the graves of Muhammad, 'Alī, Abū Bakr, and 'Umar. Thus, Saudi practices aim at the desacralization of (formerly) sacred places in Mecca and Medina. Yet they also support a kind of "sacralization" of other places (ibid., 14, 17-19): the birthplace of Muhammad b. 'Abd al-Wahhāb (d. 1798), the founder of the Wahhābiyya, in Dir'iyya has been turned into a tourist attraction and museum (ibid., 14).

(5) The establishment of haram districts in the Hijāz must have had a direct effect on Jews and Christians living on the Arabian Peninsula because they were forbidden to enter or to reside in Mecca and Medina. The prohibition is based on a saying by Muhammad ${ }^{17}$ as well as on accounts of early Muslim scholars stating that in the time of the second caliph, 'Umar b. al-Khațțāb (d. 644), the Hijāz or the whole Arabian Peninsula was freed from the presence of non-Muslims through expulsion (Munt 2015, 250).

However, Muslim scholars debated the concrete implementation of this ruling for several centuries, and the evidence of expulsions is questionable. The existence of Jewish and Christian communities within the Hijāz and on the Peninsula was reported by various Muslim sources throughout the early Islamic centuries; in Yemen, the Jewish presence lasted up to the twentieth century (ibid., 251, 259-261). Jurists' rulings in the early centuries also varied considerably regarding which places non-Muslims were allowed to enter (ibid., 257f.). As scholars assumed that all non-Muslims had been expelled, they constructed or altered the geographical definition of Hijāz/Arabia, in the sense that Hijāz/Arabia could be only where non-Muslims were not living (ibid., 263). A source-critical study has trouble identifying the historical background of reports on Muslim persecutions of Jews in Medina at the times of the prophet Muhammad (Schöller 1998). The picture given by reports depicting the massacre of up to 900 men of the Jewish Banū Qurayẓa in Medina is far from clear; it is difficult to establish whether the expulsion of Jews from Medina really happened or to what kind of historical event these reports might refer. However, the importance of this trope in the cultural memory is attested by the fact that two of the three illustrations about the Medinan period in the Khalili manuscript of the Jāmi` al-tawārīkh (1306-1311 CE), which was composed by the

17 There are different versions stating that "two religions should not join/remain in the peninsula/land of the Arabs" (Munt 2015, 250f., 255-259). 
Jewish convert Rashīd al-Dīn al-Ḥamdānī (d. 1318), show Muhammad's raids against the Banū Năḍir and the Banū Qaynūqa', respectively (Hillenbrand 2014). In any case, the partial and gradual implementation of the haram districts is another hint at the fact that the emergence of the sacred Islamic centre seems to have been a gradual process (Munt 2015, 251). The prohibition for Jews and Christians to stay in the Hijāz, and the difficulty to implement this prohibition, implicitly affirm the right of Jews and Christians to reside in the, however defined, rest of the lands under Muslim control.

(6) When non-Arabic and Arabic sources from the mid-seventh century CE onwards talk about the origins of Islam (see, for example, Hoyland 1997), we have to take into consideration the simple fact that Arabs and Muslims already controlled a vast territory, extending from Europe to India and Central Asia at that time, while Arab traders had reached ports in China, although they might not yet have built mosques there. ${ }^{18}$ If Islamic empire building had not been successful, there would have been no demand for written accounts about the origins of Islam, be it in Arabic or non-Arabic languages. Muslim historians of the eighth and ninth centuries CE were not only concerned with adjusting biblical stories to their own narratives, but they already drew on the history of China, India, and ancient Egypt as a pre-history (Donner 1998, 127-134). Later examples in the genre of universal history include chronicles written by Christian authors who depicted history from Adam to their lifetime, for example the historian Jirjis b. al-'Amīd (known as al-Makīn, d. 1273 CE) from Egypt, in his Majmū' al-mubārak (1262-1268) (e.g. Frenkel 2015, 83-91), or the Syrian-Orthodox Bishop Gregory Bar Hebraeus (d. 1286) from Persia, who wrote in Syriac and Arabic (e.g. Todt 1988). Another famous example is the chronicle Jāmi' al-tawārīkh (1306-1311 CE), by the Jewish convert Rashīd al-Dīn, which is considered the first written world history (Melville 2008) not only because of the breath of topics, from Adam to the Mongols, but also because its author combined a variety of sources to depict the histories of the Chinese, Arabs, Persians, Indians, Jews, and Franks.

From this consideration follows a challenge for historiography and spatial imagination, because the search for the origins of Islam is always already a back projection in which earlier and later events as well as distant regions and Arab centres are interconnected. With regard to the historiographic challenge, even early accounts about the emergence of Islam are tinged with an understanding of the later events of the Arab-Muslim expansion that had already changed Muslims and Islam, both of which had emerged under conditions that were, in all probability, different from those in

18 Although the foundation of the Huaisheng Mosque in Guangzhou is often said to go back to the seventh century CE, there are no near-contemporary Chinese sources that support such a claim. A secure dating of Islamic buildings prior to the Mongol conquest of China and the fourteenth century is not possible (Steinhardt 2015). 
which the accounts about their origins and expansion were written. With regard to the spatial challenge, the dissolution of boundaries and the crossing of frontiers went hand in hand with processes of empire building - the strengthening of a centre in Baghdad and regional sub-centres - and with processes of legitimatization, in which accounts of Arab conquests obviously played an important role. These processes also induced a geographical and historiographic re-orientation to the past and to the Arabian Peninsula. Phenomena like the introduction of the mihrāb in mosque architecture and the growing importance of the hajj (see the next point) can probably be understood as a physical expression of an interlocking between the Arab expansion and the Muslim re-connection to the past and the Arab Peninsula.

(7) In mainstream and revisionist views of early Islam, the importance accredited to Mecca and Medina stems from the question of how or whether Islam spread from there to other places. From a topological point of view, the importance of these places rather stems from the routes taken to them and from their (changing) relations to other places. Mecca and Medina not only attracted Muslim travellers like Nāșir-i Khusraw (d. 1072/78) from Central Asian Merw (hajj in 1050), Ibn Jubayr (d. 1217) from Valencia (hajj in 1184), and Ibn Bațțūta (d. 1368/77) from Morocco (hajj in 1326) (Peters 1994a, 71). Since the early sixteenth century, the cities of Mecca and Medina also stirred the curiosity of European travellers and writers, who had to dress and behave like Muslims and profess Islam when they visited them (Peters 1994b, 206-265). The Italian Ludovico de Varthema (d. 1517) saw Mecca and Medina in 1503, and portrayed them in detail as the first European in 1510; Joseph Pitts (d. 1735?) entered Mecca presumably as a slave and depicted the hajj rites in his report of 1704. In the nineteenth century, Johann L. Burckhardt, Richard F. Burton (d. 1890), and Charles M. Doughty (d. 1926) published their popular travelogues in 1829, 1857, and 1888, respectively.

Moreover, Peters $(1994 b, 71)$ highlights that there also exists a body of geographical writing in Arabic that is committed to describing the social, historical, and architectural dimensions of the Holy Lands of Islam. He particularly emphasises its roads and stations: "The very earliest example of the genre, by Ibn Khurdadhbih (d. 893-894), is in fact called The Book of Routes and Provinces, as are many of its successors, including those of Istakhri (ca. 951) and Ibn Hawkal (ca. 977)" (ibid., 71f.). Thus, since the ninth century, Muslim narratives about places underline their connectivity, linking the centrality and universality of such places as Mecca, Medina, Jerusalem, and Baghdad with their boundedness and particularity (Antrim 2012, 33-60). Petersen (2018, 87121), who explores the Chinese-language Islamic texts collected in the Han Kitab of the eighteenth century, has shown how the meaning and practice of the hajj changed from a Chinese-Muslim point of view over the centuries. By comparing the works of the three Sino-Muslim authors Wang Daiyu (d. 1658), Liu Zhi (d. 1724), and Ma Dexin (d. 1874), 
he elucidates that the perception of the hajj turned from "a symbol of true belief, to a potential critical practice, and finally to an essential observance and religious duty" (ibid., 87).

That Mecca and Medina were not the centres of political power for most of their history also helped to turn them into a cosmopolitan meeting point for scholars, pilgrims, and refugees. Although the local rulers of the Hijāz had to come to terms with different overlords throughout the centuries, the strategically peripheral location spared them attacks since the times of the Qarmatians up to the beginning of the nineteenth century. Standing outside the formal hierarchy of the Ottoman Empire, Medina was in a position to become one of the most important centres of Muslim scholarship from the sixteenth century onwards, as Reichmuth $(1998 ; 2000)$ has shown. There, a Kurdish theologian could come into contact with scholars from Timbuktu, have a pupil from Sumatra, and write a commentary to a work by an Indian colleague. Or an Indian scholar, studying in the Hijāz, could build up a scholarly network reaching from Western Africa over the Maghreb to India and Central Asia. The growing presence of scholars from Daghestan and the Western Sahara since the seventeenth century illustrates the flowering and consolidation of Islamic culture and Arabic scholarship in these regions as well as a growing awareness and appreciation among Arab Muslims for these groups and regions.

A turning point in Mecca's and Medina's history was the moment when European shipping companies started to offer hajj travels by steamships in the nineteenth century and "applied the same business logic and mechanisms that they deployed in the transportation of other populations" (Miller 2006, 192; also Peters 1994b, 266-300; Slight 2017). The organisation of the hajj to Mecca began changing massively, and the numbers of pilgrims from South Asia jumped to unknown heights at the beginning of the twentieth century (Miller 2006). When air travel was introduced, and procedures for pilgrims from all over the world further standardized, in the mid-twentieth century, the lines between pilgrimage and tourism were further blurred and the effect of globalisation transformed a pillar of Islam into a religious, yet highly commercial, form of tourism (McLoughlin 2018).

(8) The spread of Islam and the movements of Islamic conquests did not end with the Arab expansion of the first century AH. Rather, a series of conquests and reconquests by various tribal, ethnic, and religious groups from different places occurred in the following centuries. These include the movement of the Arab Banū Hilāl across Northern Africa to Mauretania from the tenth century onwards; the re-conquests of the Maghreb and Muslim Iberia by Berber groups, the Almoravids and the rival Almohads, in the eleventh and twelfth centuries; the conquests of the originally non-Muslim Mongols, who helped spread Islam further across Eurasia; and the conquests of the Ottomans, 
who took the chance to subdue big swaths of already "Islamic" land in the fifteenth and sixteenth centuries (Reinkowski 2016). Especially the Mongolian impact, whose origins are potentially as "dark" as the Islamic ones, is worth mentioning, because the originally non-Muslim Mongols helped spread Islam to new regions in Central Asia, India, Russia, and Poland, intensified the trans-regional traffic of goods, travellers, and refugees, and produced a common space of interaction, imagination, and destruction (Jackson 2017).

In this broader sense, it is certainly one-sided to attach the emergence of Islam to a singular place like Mecca/Medina when there were multiple, polycentric, and continuous efforts of new beginnings in Islam. There are many examples, ranging from different Sūfī orders to the Wahhābiyya, that show how movements of religious renewal spread from different places. A case in point is the Naqshbandiyya-Mujaddidiyya, founded by Aḥmad Sirhindī (d. 1624) in India (Reichmuth 1998; 2000). As Sirhindī and his adherents broke with the previous mystical universalism in India, relations to the Moghul emperors became strained, so that initial support turned into prosecution. While Sirhindī's major opus was officially forbidden in 1679, and a fatwā from the Hijāz posthumously declared him an unbeliever in 1682, the order spread in the Ottoman Empire and was officially recognized in the aftermath of the disastrous campaign against Vienna in 1683, which ended the predominance of the Kadizadelis at the Porte. Beginning in the eighteenth century, the Mujaddidiyya further spread to Central Asia, Russia, Egypt, and North Africa. Finally, it helped to bring about the political and administrative reforms in the Ottoman Empire of the nineteenth century and played a role in the coterminous disempowerment of the Janissaries and the Bektāshīs, a rival Sūfĩ order.

(9) The importance attested to revisionist scholarship on the previous pages does not stem from its alternative readings of Islamic origins. It rather serves as another example of the temporal and spatial extension of what is termed as "Islamic origins," since the distant past is connected to present research and definitions of Islam originate in a global arena, thus attributing the understanding of pre-modern places in Arabia to modern places such as Caen, Saarbrücken, or Berlin.

From a topographical and topological point of view, the revisionist re-location of the birth of Islam closer to the heartlands of Christianity and Judaism seems to be an unnecessary operation. It is well established by now that the Arabian Peninsula was connected with the surrounding world in pre-Islamic times and that Arabs themselves had already spread beyond the peninsula (e.g. Hoyland 2001). The northern and southern parts of Arabia fell, at different times, under Roman, Byzantine, Persian, and Ethiopian rule. The trade routes running from South Arabia in pre-Islamic and Islamic times connected distant places with each other. The incense route ran from Dhofar 
by land or by sea to Jeddah, Gaza, Damascus, and Petra, ${ }^{19}$ while sea trade connected India to Egypt. Arabian culture outside the Peninsula can be traced back to the Bronze Age (Hoyland 2001), and even paleogenetics suggests that Arabs were migrating to the North of the Peninsula and returning to it long before Islam (Tadmouri et al. 2014, 396f.).

The geographical rapprochement of early Muslims to Christian and Jewish lands in order to explain their entanglement follows neither from a spatial argument nor from philological detail work alone. It reflects tropes that have dominated Western religious and scholarly discourses about Islam for centuries. ${ }^{20}$ Lüling (1993, ix-xii, 15-23; 2007) is quite explicit in this respect because he not only dedicated his work to the reformed theologian Martin Werner (d. 1964), but also subscribed to the latter's view that the doctrine of the Trinity was not part of Early Christianity but a Hellenistic, RomanImperial "distortion" of Jesus' self-image (Lüling 1993, ix). Lüling's motivation was to prove that the Early Christian non-Trinitarian understanding of Jesus was "exactly" reproduced in the Qur'ān. He held to have "irrefutably" proven that the Qur'ān and the history of the emergence of Islam was falsified in the first two centuries by the emerging Muslim "orthodoxy," which also "fundamentally" re-interpreted the historical figure of Muhammad (ibid.). Against this background, he asked Christianity to concede that Islam alone preserved the correct Early-Christian understanding of Jesus, while he demanded that Islam accept that its own genesis was forged in a profound sense (ibid., ix-x). He understood his research results as prolegomena for ecumenical dialogue between the religions, because the dogma of the Trinity posed the main point of difference between Christianity and Islam (Lüling 2007, 297). As he aligned himself with the rationalism of the Enlightenment, the historical-critical school, and a Christian theology critical of church dogmata, he also understood his research results as the "fulfilment" of the critical Qur'ānic studies of the last two centuries (ibid., 301f.). He had few positive words reserved for scholars of Islamic studies since the second half of the twentieth century, because in his view, they had resumed neither the critical research of liberal Protestant theology nor the liberal Qur'ānic studies of the nineteenth and early twentieth centuries. Lüling's personal background was that he began to study theology and specialised in the Hebrew Bible, but could not hope to become pastor because of his anti-Trinitarian stance. Therefore, he transferred to the department of Islamic studies, where his qualification work of 1969 (extended version in 1973/74 and 1993) met with determined resistance-in spite of some non-public encouragement-

19 According to Bukharin (2010), the incense route also ran to Mecca, in spite of Crone's (1987) arguments mentioned above.

20 See also my article "Towards a Multi-Religious Topology of Islam: The Global Circulation of a Mutable Mobile" in this volume. 
so that he lost his academic position and had to end his university career, while his research was not discussed in Germany for several years (Lüling 2007, 300-306); it only found belated recognition and reception by Anglo-Saxan scholars after he had published his findings in English (Lüling 2003).

In this respect, the questions and doubts about the emergence, redaction, and composition of the Qur'an have less to do with the nature of Islam itself than with the question of the purpose of critical research and academic debate (for a critical Muslim view, see Bagrac 2010). Rivaling viewpoints on the origins of Islam not only express a lasting circulation of known tropes and their rearrangement, but also serve as a means to negotiate one's own scholarly self-understanding about the purpose and aim of academic research.

\section{Conclusion}

Where do the multi-religious origins of Islam lie and what do they tell us? Trying to answer this question, I have firstly identified the historiography of the emergence of Islam as a "wicked problem" that resists a clear and simple resolution. I have tried to pinpoint tricky and malicious problems in revisionist and mainstream scholarship on the previous pages. The focal point was the controversial spatiality of early Islam and its entanglement with Judaism and Christianity. My intervention, although not aiming at a consensus, intended to bring Islamic tradition, mainstream scholarship, and revisionism into discussion with each other and turn divisive certainties into perplexities. In this respect, I have tried to show that the attempts of mainstream and revisionist scholarship to defend or relocate the birthplace of Islam follow from a limited understanding of space. Classical Orientalist scholarship tried to distinguish the "true" historical kernel on the origins of Islam in early Arabic literature-an attempt that revisionist scholarship rejects with regard to Arabic sources, yet it follows the selfsame approach with regard to the primordial places of Islam. Thus, revisionism is marred by a self-contradiction, while mainstream scholarship in Qur'ānic studies seems to be trapped in a confusion between the physical and symbolic dimension of space and between the genesis and exegesis of Qur'ān, especially with regard to Mecca and Medina.

After this review of the recent literature, I have secondly argued that we should understand the birthplaces of Islam neither as a literary "invention" nor as a given fact. I have argued for their social and historical construction, thus opposing total arbitrariness as well fixed immobility in location, shape, and meaning. My point of view is that Islam did not come into being "in" Mecca or any other spatial container, but that 
Muslim actions and mobility produced the space of early Islam physically, symbolically, and emotionally. I have further argued that Islam - as a full-fledged religious worldviewemerged neither in a barren place nor at the crossroads of civilizations. Instead, its formation happened through a longer, polycentric historical process. By following a topological approach, I have tried to elucidate that the constitution of places called Mecca and Medina and the attribution of historical, symbolic, imaginative, emotional, and representative quality to them were intertwined processes. I have further suggested that the production of the sacrality for Mecca and Medina in turn ascertained the general multi-religious topology of Islam.

Thirdly, I have concluded that the Islamization, sacralisation, and growing importance of Mecca and Medina were gradual historical processes in a multi-religious landscape-although we have only limited information in the sources about spatial and social practices in early Islam. However, these processes of sacralisation involved the restructuring of the Ka'ba, the Haram districts, and the adjacent quarters as well as investments in infrastructure and security, mirroring the growing importance of hajj and ziyāra. It also seems to have been beneficial for the emergence and preservation of Mecca's and Medina's sacred character that both cities were remote from the political centres of Islam for most of their history, which allowed them to thrive as centres of religious scholarship and retreat in the shadow of political turmoil. From here, the Islamic and sacred character of Mecca is understood as a product of spatial practices that have evolved over time and distributed meaning partly in contradictory ways. For example, the Islamic character of archaeological sites in Mecca did not save them from destruction by an Islamic government; and the growing number of pilgrims to Mecca and Medina moved the hajj closer to tourism.

I have taken issue with the consensual use-in an otherwise differing scholarshipof a somewhat ossified concept of Late Antiquity that originally was an opener to integrate Islam into a larger vision of global history (e.g. Brown 1971; 1978; Fowden 2015; 2016). In studies on the Qur'ān and early Islam, this concept either proceeds from entanglement to reach uniqueness or envisions cross-fertilization, yet argues with the early in/stability of religious entities whose contours, practices, and norms are mainly unknown to us. My counterargument was to focus on internal diversity, dynamic development, and re-negotiation. The in/stability of what is called early Islam must be understood as a relational phenomenon in comparison with the in/stability of similar umbrella terms, such as paganism, Judaism, and Christianity in the same period (see Al-Azmeh 2014). Early Arabic-Muslim sources give a complex and dynamic picture of rivalries and alliances between different tribes and groups in which differing religious views did not always play the most important role. 
Drawing on this argument, my fourth point is that religious diversity in Arabia tells us exactly this - that diversity lay at the cradle of Islam, existed before its birth, and lingered on after it. This multi-religious topology of Arabia is directly connected with the problem of defining what "religion" (or "Islam") is. Taking into account Smith's (1982, xi) argument that "religion" emerges through second-order acts of classification and therefore is "solely the creation of the scholar's study," ${ }^{21}$ means to take the problem of classification seriously. When a scholar describes Islam as an anti-Trinitarian form of Christianity, then the scholar's boundary work implicitly creates a division as well as a common denominator. At the same time, this operation marks and unmarks what Islam is and establishes closeness as well as distance to Judaism and Christianity. Mainstream as well as revisionist scholarship on the birth of Islam often connects chronology with causality and treats Islam as the result of various religious impacts. In contrast, a topological approach is critical of the lasting "influence of influences" (Tauber 2018) and rather looks at the human practices that constitute $X$ and $Y$ as distinct categories to establish a chronology as well as an authoritative relation between them. Therefore, it is important to note that (1) "the Bible is at the same time everywhere and nowhere in the Arabic Qur'ān" (Griffith 2013a, 2); (2) Jewish and Christian traces on the Arab Peninsula are attested in literature and archaeology, although we do not know exactly what kind of Jews and Christians were there; and (3) Arabs had far-reaching contacts beyond the Arab Peninsula long before the advent of Islam. These aspects suggest the existence of physical and imaginative landscapes with a diverse and multi-religious character. As the earliest sources show, the actors seem to have negotiated this diversity by various practices and discourses. Thus, early Islam was not only entangled with other religious traditions and cults, but also linked to opposing practices and discourses-ranging from the acceptance of religious plurality (as expressed in the socalled constitution of Medina) to fields of ambiguity (as expressed in debates about the presence and the rights of Jews and Christians in the Hijāz) to tendencies of purification (as expressed in narrations about the expulsion of Jews from Medina or inner-Islamic conflicts). As these practices and discourses of "un/doing difference" (Hirschauer 2014) lingered on in later centuries, it seems questionable to ascribe either "dark origins" or a full-fledged theological concept to Islam of the first century AH when we have a thriving culture of Muslim debate that explores, time and again, the origins and the meaning of Islam up to this day.

Therefore, regarding the geographical rapprochement of Paleo-Muslims to Christian and Jewish lands in revisionist scholarship, my argument was that it is supported neither

21 According to Smith, "while there is a staggering amount of data, of phenomena, of human experiences and expressions that might be characterised in one culture or another, by one criterion or another, as religious - there is no data for religion" (Smith 1982, xi; emphasis in the original). 
by a spatial point of view nor by philological detail work alone. It reflects tropes-Islam as an anti-Trinitarian heresy - that have dominated Western religious and scholarly discourses about Islam for centuries. This brings us back to question of the sitz im leben of Qur'ānic studies and studies on early Islam; they are located inside the hierarchies of knowledge production that often serve political projects to the disadvantage of the colonial or post-colonial "other". My contribution questions the way in which the heterogeneous research on the origins of Islam has attained growing importance against the background of current popular debates on Islam. The popular negative image of Islam certainly poses an additional, new challenge to the scholarship of early Islam, since populist critics of Islam also tend to eclectically draw on critical research.

Against this backdrop, it seems legitimate to ask what drives the new ambitions of research on the origins of Islam, as we seem to make only little actual progress and probably know more about the historical Muhammed a priori than about Jesus, Moses, or the Buddha, as even Crone (2008) has admitted. Maybe the trope from a Greek text, written between 632 and 634, that "a false prophet has appeared among the Saracens" (ibid.) is still key to understanding the subliminal forces that guide at least parts of the debate. The trope of falseness seems to make a difference. Whereas the riddle of whether Buddha's supreme wisdom came into this world in the sixth, fifth, or fourth century BCE is mainly discussed by academic scholars, ${ }^{22}$ the fierce debate about the beginnings of Islam suggests that some participants believe it necessary to defend Islam while others think that Muhammad's forgery is still waiting to be fully unmasked.

Andrew Rippin (2012) recently pondered about the negative Muslim reception of "secular, academic scholarship" (ibid., 2), which he also called "Euro-American scholarship," although he immediately recognized that this kind of terminology "is fraught with difficulty" (ibid., 5). He then takes himself to task because he falls into the trap of the underlying cultural assumptions of the West versus Islam: "It is a fact of the modern world that religious allegiance does not correspond to geographical location in any sense" (ibid.). Yet the appeal of such a faulty kind of boundary work stems from the fact that what is seen as a (Western) "polemic put forth in the guise of academic research" (ibid., 3) often triggers a (Muslim) "apologetic mode of response," which is framed as a critique of the modern/postmodern world "that does not ascribe an ultimate value to belief in the divine" (ibid.). Decidedly Muslim approaches then try to reconcile research with belief in the Qur'ān as a book "in which there is no doubt"

22 Since the nineteenth century, there has been a controversial debate about the dates of birth and death of S. Gautma, who is believed to have lived sometime between the sixth and fourth centuries BCE (e.g. Bechert 1982 and 1991-1997; Gombrich 2000). However, this debate is not comparable in terms of acrimony and scope with the current hypotheses and speculations about the emergence of Islam. 
(referring to Qur'ān 2:2) and often end up in "sweeping arguments which can neither be proved nor disproved and must be seen as part of broader protest against Western domination" (ibid. 4, quoting Waardenburgh 1993). As Rippin admits, the "West versus Islam" classification is questionable, since Muslim as well as non-Muslim scholars are involved in Islamic and Qur'ānic studies in a critical and constructive manner; the challenge for everyone, he writes, lies in "putting negative images behind us and dissociating ourselves from work that is not worthy of being called scholarship" (ibid. 6).

However, the nature of serious scholarship is a question in the scholarly debate itself, as I have tried to show on the previous pages. The controversial debate about the nature and origins of Islam is a case in point. It serves rivalling scholars as a way to substantiate their respective understanding of the meaning and aim of historicalcritical research and works to stabilize scholarly hierarchies as well as camp thinking. In this sense, the debate so far has often had the tendency to be a spatial practice and boundary work in its own right. It should be opened up for new transgressions.

\section{Literature}

Al-Azmeh, Aziz. 2014. The Emergence of Islam in Late Antiquity. Allāh and his People. Cambridge: Cambridge University Press.

Antrim, Zayde. 2012. Routes and Realms: The Power of Place in the Early Islamic World. Oxford: Oxford University Press.

Bacharach, Jere L., and Sherif Anwar. 2012. "Early Versions of the shahāda: A Tombstone from Aswan of 71 A.H., the Dome of Rock, and Contemporary Coinage." Der Islam 89 (2): 60-69.

Bagrac, Musa. 2010. "Ein Abriss der bisherigen Geschichte der deutschen Koranforschung." Islamische Zeitung. September 24, 2010. https://www. islamische-zeitung.de/ein-abriss-der-bisherigen-geschichte-der-deutschenkoranforschung-von-musa-bagrac.

Bangert, Kurt. 2016. Muhammad. Eine historisch-kritische Studie zur Entstehung des Islams und seines Propheten. Wiesbaden: Springer.

Bashear, Suliman. 1989. "Qur'ān 2:114 and Jerusalem." Bulletin of the School of Oriental and African Studies 52 (2): 215-238.

Bechert, Heinz. 1982. "The Date of the Buddha Reconsidered." Indologica Taurinensia 10: 29-36.

- - , ed. 1991-1997. The Dating of the Historical Buddha, vol. 1-3. Göttingen: Vandenhoeck \& Ruprecht. 
Beeston, A.F.L. 1988: "Review of 'The Bible Came from Arabia'." Journal of the Royal Asiatic Society: 389-93.

Behrens, Marcel. 2007. "Ein Garten des Paradieses". Die Prophetenmoschee von Medina. Würzburg: Ergon.

Berger, Lutz. 2016. Die Entstehung des Islam. Die ersten hundert Jahre. Von Mohammed zum Weltreich der Kalifen. München: Beck.

Bindley, Thomas Herbert, ed. 1899. The Oecumenical Documents of the Faith. The Creed of Nicaea. Three Epistles of Cyril. The Tome of Leo. The Chalcedonian Definition. London: Methuen \& Co.

Bobeck, Adam. 2018. “Die Dekonstruktion der Geschichte. Raum, Identität und Ğannat al-Baqī'." Spektrum Iran 31 (3): 1-23.

Bobzin, Hartmut. 2010. Der Koran. Neu übertragen von Hartmut Bobzin. München: Beck.

- -.${ }^{9} 2015$. Der Koran. Eine Einführung. München: Beck.

Botz-Bornstein, Thorsten. 2015. Transcultural Architecture. The Limits and Opportunities of Critical Regionalism. Farnham: Ashgate.

Brown, Peter. 1971. The World of Late Antiquity from Marcus Aurelius to Mohammed (AD 150-750). London: Thames and Hudson.

- - . 1978. The Making of Late Antiquity. Cambridge, Mass.: Harvard University Press.

Brunner, Rainer. 2001. Die Schia und die Koranfälschung. Würzburg: Ergon.

Bukharin, Mikhail D. 2010. "Mecca on the Caravan Routes in Pre-Islamic Antiquity." In Neuwirth, Sinai, and Marx 2010, 115-134.

Burton, John. 1977. The Collection of the Qur'ān. Cambridge: Cambridge University Press.

- - . 1993. "Law and Exegesis: The Penality for Adultery in Islam." In Approaches to the Qur'an, edited by Gerald R. Hawting and Abdul-Kader A. Shareef, 269-284. London: Routledge.

Busse, Heribert. 1993. "Geschichte und Bedeutung der Kaaba im Licht der Bibel." In Zion - Ort der Begegnung. Festschrift für Laurentius Klein zur Vollendung des 65. Geburtstages, edited by Ferdinand Hahn et al., 169-185. Bodenheim: Athenäum.

Crone, Patricia. 1987. Meccan Trade and the Rise of Islam. Princeton, N.J.: Princeton University Press.

-_-. 2005. "How did the Quranic Pagans Make a Living?" Bulletin of the School of Oriental and African Studies 68 (3): 387-399.

- - . 2008. "What Do We Actually Know About Mohammed?" OpenDemocracy June 10, 2008. https://www.opendemocracy.net/en/mohammed_3866jsp/. 
- - . 2010. "Among the Believers. A New Look at the Origins of Islam Describes a Tolerant World That May Not Have Existed." Tablet. August 10, 2010. https:// www.tabletmag.com/jewish-news-and-politics/42023/among-the-believers.

Crone, Patricia, and Michael Cook. 1977. Hagarism. The Making of the Islamic World. Cambridge: Cambridge University Press.

Donner, Fred M. 1998. Narratives of Islamic Origins. The beginnings of Islamic Historical Writings. Princeton, NJ.: Darwin Press.

- - . 2008. "The Qur'ān in Recent Scholarship: Challenges and Desiderata." In The Qur'ān and its Historical Context, edited by Gabriel S. Reynolds, 29-50. London: Routledge.

- - . 2010. Muhammad and the Believers. At the Origins of Islam. Cambridge, Ma.: Harvard University Press.

Dozy, Reinhart. 1864. Die Israeliten zu Mekka von Davids Zeit bis in's fünfte Jahrhundert unserer Zeitrechnung. Haarlem: A.C. Kruseman.

Eliade, Mircea. 1985. A History of Religious Ideas, vol. 3: From Muhammad to the Age of Reforms. London: University of Chicago Press.

Ende, Werner. 1997. "The Nakhāwila, a Shiite Community in Medina Past and Present." Die Welt des Islams 37 (3): 263-348.

Finster, Barbara. 1991. "Cubical Yemeni Mosques." In Proceedings of the Twenty Fourth Seminar for Arabian Studies, held at Oxford on 24th - 26th July 1990, Vol. 21, 49-68. Oxford: Archaeopress

- - . 2010. "Arabia in Late Antiquity: An Outline of the Cultural Situation in the Peninsula at the time of Muhammad." In Neuwirth, Sinai, and Marx 2010, 61114.

Fowden, Garth. 2015. Before and After Muhammad: The First Millennium Refocused. Princeton, N.J.: Princeton University Press.

-_- 2016. "Late Antiquity, Islam, and the First Millenium: A Eurasian Perspective." Millennium 13 (1): 5-28.

Frenkel, Yehoshua. 2015. The Turkic Peoples in Medieval Arabic Writings. London: Routledge.

Gibson, Dan. 2011. Qur'ānic Geography. A Survey of the Geographical References in the Qur'an. Surrey, BC: Independent Scholar's Press.

Gilliot, Claude. 2006. "Creation of a fixed text." In: The Cambridge Companion to the Qur'an, edited by Jane Dammen McAuliffe, 41-58. Cambridge: Cambridge University Press.

Gombrich, Richard. 2000. "Discovering the Buddha's Date." In Buddhism for the New Millennium, edited by Lakshman S. Perera, 9-25. London: World Buddhist Foundation. 
Görke, Andreas, and Harald Motzki. 2014. "Tilman Nagels Kritik an der isnad-cummatn-Analyse. Eine Replik." Asiatische Studien 68 (2): 497-518.

Görke, Andreas, Harald Motzki, and Gregor Schoeler. 2012. "First Century Sources for the Life of Muhammad? A Debate." Der Islam 89 (2): 2-59.

Griffith, Sidney. 2013a. The Bible in Arabic. The Scriptures of the 'People of the Book' in the Language of Islam. Princeton, N.J.: Princeton University Press.

- - - 2013b. "When Did the Bible Become an Arabic Scripture." Intellectual History of the Islamicate World 1: 7-23.

Groß, Markus. 2014. “Der Koran-kein europäischer Text. Mehr als seine Rezension zu Angelika Neuwirth: 'Der Koran als Text der Spätantike-ein europäischer Zugang." In Groß and Ohlig 2014, 803-931.

Groß, Markus and Ohlig, Karl-Heinz, eds. 2014. Die Entstehung einer Weltreligion III. Die heilige Stadt Mekka - eine literarische Fiktion. Inârah-Sammelband 7. Berlin: Schiler.

Haider, Najam. 2011. The Origins of the Shi'a: Identity, Ritual, and Sacred Space in Eighth-Century Kufah. Cambridge: Cambridge University Press.

Hawting, Gerald R. 1982. "The Origins of the Islamic Sanctuary at Mecca." In Studies on the First Century of Islamic Society, edited by G.H.A. Juynboll, 25-47. Carbondale: Southern Illinois University Press.

- - . 1999. The Idea of Idolatry and the Emergence of Islam. Cambridge: Cambridge University Press.

Heidemann, Stefan. 2007. "Münzen sind konservativ. Der frühe Islam im Spiel des numismatischen Befundes." Frankfurter Allgemeine Zeitung (28.02).

-_- 2010. "The Evolving Representation of the Early Islamic Empire and its Religion on Coin Imagery." In Neuwirth, SInai, and Marx 2010, 149-195.

Hillenbrand, Robert. 2014. "Muhammad as Warrior Prophet. Images from the World History of Rashid al-Din." In The Image of the Prophet between Ideal and Ideology. A Scholarly Investigation, edited by Christiane Gruber and Avinoam Shalem, 65-75. Berlin/Boston: De Gruyter.

Hirschauer, Werner. 2014. “Un/doing Difference. Die Kontingenz sozialer Zugehörigkeiten." Zeitschrift für Soziologie 43 (3): 170-191

Hoyland, Robert G. 1997. Seeing Islam as Others Saw It: A Survey and Evaluation of the Christian, Jewish, and Zoroastrian Writings on Early Islam. Princeton: Princeton University Press.

---. 2001. Arabia and the Arabs. From the Bronze Age to the Coming of Islam. London: Routledge. 
Hughes, Aaron W. 2015. "Review of The Religious and Spiritual Life of the Jews of Medina. By Haggai Mazuz." Journal of the American Academy of Religion 83 (2): 580-582.

- - . 2017. "Religion Without Religion: Integrating Islamic Origins into Religious Studies." Journal of the American Academy of Religion 85 (4): 867-888.

Ibn Warraq. 2005. "A Personal Look at Some Aspects of the History of Koranic Criticism, $19^{\text {th }}$ and $20^{\text {th }}$ Centuries." In Ohlig and Puin 2005, 212-247.

Jackson, Peter. 2017. The Mongols and the Islamic World. From Conquest to Conversion. New Haven: Yale University.

Kerr, Robert. 2014a. "Ist der Qur'ān in Mekka oder Medina entstanden?" In Groß and Ohlig 2014, 39-45.

- - . 2014b. “Die blauen Blumen von Mekka - Von Ismaels Stadt zum Heiligtum der Ismaeliten." In Groß and Ohlig 2014, 52-174.

Khalil, Mohammad Hassan, ed. 2013. Between Heaven and Hell. Islam, Salvation, and the Fate of Others. Oxford: Oxford University Press.

Khoury, Nuha N.N. 1998. "The Mihrab: From Text to Form." Journal of Middle East Studies 30: 1-27.

Koloska, Hannelies. 2016. "Spätantikes Bildwissen im Koran. Die Relevanz ikonographischer Darstellungen für das Verständnis des Koran." In Schmidt, Schmid, and Neuwirth 2016a, 431-444.

Lake, Danielle. 2014. "Jane Addams and Wicked Problems: Putting the Pragmatic Method to Use." The Pluralist 9 (3): 77-94.

Lawson, Todd. 2009. The Crucifixion and the Qur'an: A Study in the History of Muslim Thought. Oxford: Oneworld.

Lecker, Michael. 1985. "Muḥammad at Medina: A Geographical Approach." Jerusalem Studies in Arabic and Islam 6: 29-62.

-_- 1995a. Muslims, Jews, and Pagans. Studies on Early Islamic Medina. Leiden: Brill.

-_-. 1995b. "On Arabs of the Banū Kilāb Executed Together with the Jewish Banū Qurayża." Jerusalem Studies in Arabic and Islam 19: 66-72.

- - . 2000. "Did the Quraysh Conclude a Treaty with the Anșār Prior to the Hijra?" In The Biography of Muhammad. The Issue of the Sources, edited by Harald Motzki, 157-169. Leiden: Brill.

-_- 2012. "Constitution of Medina." In Encyclopaedia of Islam³, edited by Kate Fleet, Gudrun Krämer, Denis Matringe, John Nawas, and Everett Rowson, 100-104. Leiden: Brill.

- - . 2016. "Were There Female Relatives of the Prophet Muhammad among the Besieged Qurayza." Journal of the American Oriental Society 136 (2): 397-404. 
- - 2017. "The Monotheistic Cousins of Muḥammad's Wife Khadīja." Der Islam 94 (2): 363-384.

Lüling, Günter. 1985. “Ein neues Paradigma für die Entstehung des Islam und seine Konsequenzen für ein neues Paradigma der Geschichte Israels." In Sprache und Archaisches Denken: Neun Aufsätze zur Geistes- und Religionsgeschichte, 193226. Erlangen: Hannelore Lüling.

- - . 1993. Über den Urkoran. Ansätze zur Rekonstruktion der vorislamischchristlichen Strophenlieder im Koran. Erlangen: Verlagsbuchhandlung H. Lüling.

- - . 2000. "A New Paradigm for the Rise of Islam and its Consequences for a New Paradigm of the History of Israel." The Journal of Higher Criticism 7 (1): 23- 53. - - . 2007. "Preußen von gestern und der Islam von morgen." Aufklärung und Kritik, Sonderheft 13: 291-310.

Luxenberg, Christoph. 2004. Die syro-aramäische Lesart des Koran. Ein Beitrag zur Entschlüsselung der Koransprache. Berlin: Schiler.

- - . 2005. "Neudeutung der arabischen Inschrift im Felsendom zu Jerusalem." In Ohlig and Puin 2005, 124-148.

-_- 2007. "Relikte syro-aramäsicher Buchstaben in frühen Korankodizes in higaziund kufi-Duktus." In Der frühe Islam. Eine historisch-kritische Rekonstruktion anhand zeitgenössischer Quellen. Inâra-Sammelband 2, edited by Karl-Heinz Ohlig, 377-414. Berlin: Schiler.

- - . 2008. "Die syrische Liturgie und die "geheimnisvollen Buchstaben'." In Schlaglichter. Die beiden ersten islamischen Jahrhunderte. Inârah-Sammelband 3, edited by Markus Groß and Karl-Heinz Ohlig, 411-460. Berlin: Schiler.

Mazuz, Haggai. 2014. The Religious and Spiritual Life of the Jews of Medina. Leiden: Brill.

McLoughlin, Seán. 2018. “Hajj: How Globalisation Transformed the Market for Pilgrimage to Mecca." The Conversation August 15, 2018._https://theconversation.com/hajjhow-globalisation-transformed-the-market-for-pilgrimage-to-mecca-97888.

Melville, Charles. 2008: "Jāme‘ al-tawārik.." In Encyclopædia Iranica. Accessed October, 4, 2018. http://www.iranicaonline.org/articles/jame-al-tawarik.

Miller, Michael B. 2006. "Pilgrims' Progress: The Business of the Hajj." Past and Present 191: 189-228.

Möhring, Hannes. 1994: “Mekkawallfahrten orientalischer und afrikanischer Herrscher im Mittelalter." Oriens 34: 314-329.

Morris, Ian D. 2018. "Mecca and Macoraba." Al-'Ușūr al-Wusțā 26: 1- 60.

Motzki, Harald, ed. 2000. The Biography of Muhammad. The Issue of the Sources. Leiden: Brill. 
- - . 2001. "The Collection of the Qur'ān. A Reconsideration of Western Views in Light of Recent Methodological Developments." Der Islam 87: 1-34.

Munt, Harry. 2014. The Holy City of Medina: Sacred Space in Early Islamic Arabia. Cambridge: Cambridge University Press.

- - . 2015. "'No two religions': Non-Muslims in the early Islamic Hijāz." Bulletin of SOAS 78 (2): 249-269.

Nevo, Yehuda D., and Judith Koren. 2003. Crossroads to Islam: The Origins of the Arab Religion and the Arab State. Amherst, NY: Prometheus.

Neuwirth, Angelika. 2010a. Der Koran als Text der Spätantike: Ein europäischer Zugang. Berlin: Verlag der Weltreligionen.

- - . 2010b. "Qur'anic Readings of the Psalms." In Neuwirth, Sinai, and Marx 2010, 733-778.

- - . 2016. "Wissenstransfer durch Typologie. Relektüren des Abrahamsopfers im Koran und im islamischen Kultus." In Schmidt, Schmid, and Neuwirth 2016a, 169-207.

Neuwirth, Angelika, Nicolai Sinai, Michael Marx, eds. 2010. The Qur'ān in Context. Historical and Literary Investigations into the Qur'ānic Milieu. Brill: Leiden.

Nöldeke, Theodor. ${ }^{3} 1970$. Geschichte des Qorâns, edited by Friedrich Schwally, Goffhelf Bergsträsser, and Otto Pretzel (Leipzig 21909-1938). Hildesheim: Olms.

Ohlig, Karl-Heinz. 2009. "Von Bagdad nach Merw. Geschichte rückwärts gelesen.” In Vom Koran zum Islam. Schriften zur frühen Islamgeschichte und zum Koran. Inârah-Sammelband 4, edited by Markus Groß and Karl-Heinz Ohlig, 29-106. Berlin: Schiler.

-_- 2014. "Wer hat den Koran geschrieben? Ein Versuch." In Groß and Ohlig 2014, 421-442.

Ohlig, Karl-Heinz, and Gerd-R. Puin, , eds. 2005. Die dunklen Anfänge. Neue Forschungen zur Entstehung und frühen Geschichte des Islam. Inârah-Sammelband 1. Berlin: Schiler.

Peters, Francis E. 1986. Jerusalem and Mecca. The Typology of the Holy City in the Near East. New York: New York University Press.

- - . 1994a. Mecca: A literary history of the Muslim Holy Land. Princeton, N.J.: Princeton University Press.

-_- 1994b. The Hajj: The Muslim Pilgrimage to Mecca and the Holy Places. Princeton, N.J.: Princeton University Press.

Petersen, Kristian. 2018. Interpreting Islam in China: Pilgrimage, Scripture, and Language in the Han Kitab. New York, NY: Oxford University Press.

Popp, Volker. 2005. "Die frühe Islamgeschichte nach inschriftlichen und numismatischen Zeugnissen." In Ohlig and Puin 2005, 16-123. 
Puin, Gerd-R. 2011. "Vowel Letters and Ortho-Epic Writing in the Qur'ān." In New Perspectives on the Qur'ān. The Qur'ān in its Historical Context 2, edited by Gabriel S. Reynolds, 147-190. London: Routledge.

_-_. 2014. "Abermals: Hieß Mohammed ,Muhammad'?" In Groß and Ohlig 2014, 699730.

Ralston, Joshua. 2017. "Islam as Christian Trope: The Place and Function of Islam in Reformed Dogmatic Theology." The Muslim World 107: 754-776.

Reichmuth, Stefan. 1998. "The Interplay of Local Developments and Transnational Relations in the Islamic World: Perceptions and Perspectives." In Muslim Culture in Russia and Central Asia from the 18th to the Early 20th Centuries. Vol. 2: Inter-Regional and Inter-Ethnic Relations, edited by Anke von Kügelgen, Michael Kemper, and Allen J. Frank, 5-38. Berlin: Schwarz.

- - . 2000. “'Netzwerk' und 'Weltsystem'. Konzepte zur neuzeitlichen 'Islamischen Welt' und ihrer Transformation." In Die islamische Welt als Netzwerk. Möglichkeiten und Grenzen des Netzwerkansatzes im islamischen Kontext, edited by Roman Loimeier, 53-86. Würzburg: Ergon.

Reinkowski, Maurus. 2016. “Conquests Compared. The Ottoman Expansion in the Balkans and the Mashreq in an Islamicate context." In The Ottoman Conquest of the Balkans, edited by Oliver Jens Schmitt, 47-64. Wien: Verlag der Österreichischen Akademie der Wissenschaften.

Reynolds, Gabriel S. 2009. "The Muslim Jesus: Dead or Alive?" Bulletin of the School of Oriental and African Studies 72 (2): 237-258.

- - . 2010a. The Qur'ān and Its Biblical Subtext. London: Routledge.

- - . 2010b. "Reading the Qur'an as Homily. The Case of Sarah's Laughter." In Neuwirth, Sinai, and Marx 2010, 585-592.

- - . 2015. "Variant Readings. The Birmingham Qur'an in the context of debate on Islamic origins." Times Literary Supplement no. 5862 (August 7): 14-15.

Rippin, Andrew. 2012. “The Reception of Euro-American Scholarship on the Qur'an and tafsir: An Overview." Journal of Qur'anic Studies 14 (1): 1-8.

- - . 2013. "Qur'ānic Studies." In The Bloomsbury Companion to Islamic Studies, edited by Clinton Bennett, 59-74. London: Bloomsbury.

Rittel, Horst W. J., and Melvin M. Webber. 1973. "Dilemmas in a General Theory of Planning." Policy Sciences 4: 155-169.

Rubin, Uri. 1986. "The Ka'ba: Aspects of its Ritual Function and Position in Pre-Islamic and Early Islamic Times." Jerusalem Studies in Arabic and Islam 8: 97-131.

Saleh, Walid A. 2010. “The Etymological Fallacy and Qur'anic Studies: Muhammad, Paradise, and Late Antiquity." In Neuwirth, Sinai, and Marx 2010, 649-698.

Salibi, Kamal. 1985. The Bible Came from Arabia. London: Jonathan Cape. 
Sandmel, Samuel. 1962. "Parallelomania." Journal of Biblical Literature 81 (1): 1-13.

Sanni, Amidu O. 2015. "Book Review The Qur'an in Context Historical and Literary Investigations into the Qura'nic Milieu, edited by Angela Neuwirth, Nicolai Sinai, and Michael Marx." Journal of Islamic Studies 26 (3): 305-310.

Schmidt, Nora, Nora K. Schmid, and Angelika Neuwirth, eds. 2016a. Denkraum Spätantike. Reflexionen von Antiken im Umfeld des Koran. Wiesbaden: Harrassowitz.

-_- 2016b. "Spätantike. Von einer Epoche zu einem Denkraum." In Schmidt, Schmid, and Neuwirth 2016a, 1-35.

Schoeler, Gregor. 2010. "The Codification of the Qur'an: A Comment on the Hypotheses of Burton and Wansbrough." In Neuwirth, Sinai, and Marx 2010, 779-794.

-_- 2014. "Tilman Nagels „,Authentizität" in der Leben-Mohammed-Forschung“. Eine Antwort." Asiatische Studien 68 (2): 469-496.

Schöller, Marco. 1998. Exegetisches Denken und Prophetenbiographie. Eine quellenkritische Analyse der Sīra-Überlieferung zu Muhammads Konflikt mit den Juden. Wiesbaden: Harrassowitz.

Shah, Mustafa. 2010. “The Crucifixion and the Qur'an: A Study in the History of Muslim Thought.' By Lawson, Todd.” Journal of Qur'anic Studies, 12 (1-2): 191-203.

Shoemaker, Stephen J. 2011. "In Search of 'Urwa's Sirra. Some Methodological Issues in the Quest for 'Authenticity' in the Life of Muhammad." Der Islam 85: 257-344.

- - . 2012. The Death of a Prophet. The End of Muhammad's Life and the Beginning of Islam. Philadelphia: University of Pennsylvania Press.

- - . 2014. “'The Reign of God Has Come': Eschatology and Empire in Late Antiquity and Early Islam." Arabica 61: 514-558.

Sinai, Nicolai. 2009. Fortschreibung und Auslegung. Studien zur frühen Koraninterpretation. Wiesbaden: Harrassowitz.

-_- 2012. “,Weihnachten im Koran' oder ,Nacht der Bestimmung'? Eine Interpretation von Sure 97." Der Islam 88: 11-32.

Sinai, Nicolai, and Angelika Neuwirth. 2010. "Introduction." In Neuwirth, Sinai, and Marx 2010, 1-24.

Smith, Jonathan Z. 1982. Imagining Religion: From Babylon to Jonestown. Chicago: University of Chicago Press.

Steinhardt, Nancy Shatzman. 2015. China's Early Mosques. Edinburgh: Edinburgh University Press.

Tadmouri, G.O., K.S. Sastry, and L. Chouchane. 2014. “Arab Gene Geography: From Population Diversities to Personalized Medical Genomics." Global Cardiology Science and Practice 54: 394-408. 
Tauber, Christine. 2018. “Der Einfluss hat noch zu viel Einfluss." Frankfurter Allgemeine Zeitung (25.04.).

Todt, Susanne R. 1988. "Die syrische und die arabische Weltgeschichte des Bar Hebraeus - ein Vergleich." Der Islam 65 (1): 60-80.

Würsch, Renate. 2013. "Der Koran und seine Rezeption." Das Mittelalter 18 (1): 27-45.

Waldner, Wolfram. 2008. "Wie kam der Hund in die Siebenschläferlegende." In Studien zur Semitistik und Arabistik. Festschrift für Hartmut Bobzin zum 60. Geburtstag, edited by Otto Jastrow, Shabo Talay, and Hertha Hafenrichter, 423430. Wiesbaden: Harrassowitz.

Wansbrough, John. 1977. Quranic Studies: Sources and Methods of Scriptural Interpretation. Oxford: Oxford University Press.

Webb, Peter. 2013. "The Hajj before Muhammad. Journeys to Mecca in Muslim Narratives of Pre-islamic History." In The Hajj: Collected Essays, edited by Venetia Porter and Liana Saif, 6-14. London: The British Museum.

Wheeler, Brannon. 2006. Mecca and Eden. Ritual, Relics, and Territory in Islam. Chicago: University of Chicago Press.

Wild, Stefan. 1996. "'We Have Sent Down to Thee the Book with the Truth...' Spatial and temporal implications of the Qur'anic concepts of nuzūl, tanzīl, and 'inzāl." In The Qur'an as Text, edited by Stefan Wild, 137-153. Leiden: Brill.

- - , ed. 2006. Self-Referentiality in the Qur'ān. Wiesbaden: Harrassowitz.

-_- 2010. "Lost in Philology: The Virgins of Paradise and the Luxenberg Hypothesis." In Neuwirth, Sinai, and Marx 2010, 625-647.

Zelletin, Holger. 2016. "Aḥbār and ruhbān: Religiöse Leitfiguren im Koran im Dialog mit christlicher und rabbinischer Literatur." In Schmidt, Schmid, and Neuwirth 2016a, 125-165. 


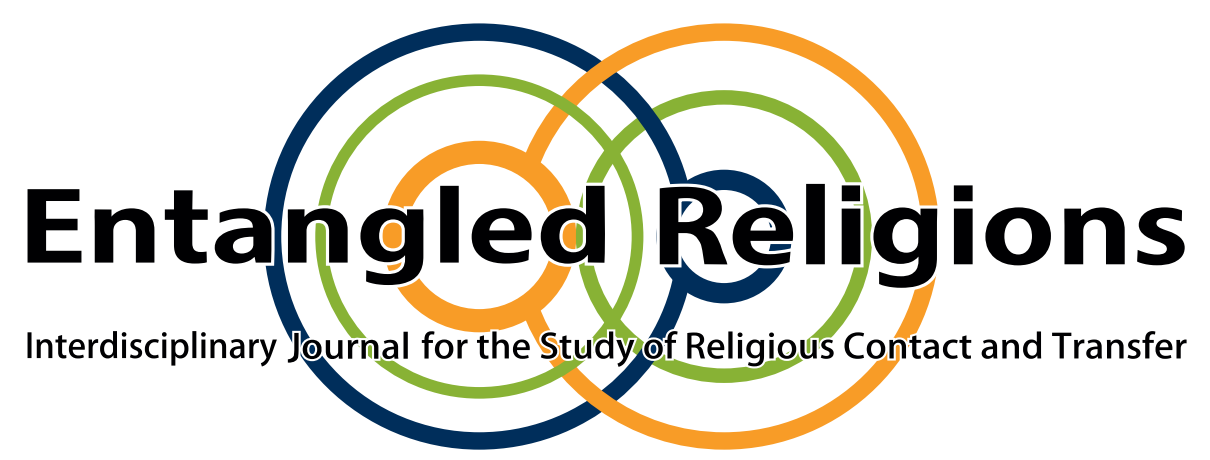

\section{Towards a Multi-Religious Topology of Islam: The Global Circulation of a Mutable Mobile}

MANFRED SING

Leibniz Institute of European History, Mainz, Germany

This contribution to Entangled Religions is published under the Creative Commons Attribution 4.0 International Public License (CC BY 4.0 International). The license can be accessed at https://creativecommons.org/licenses/by/4.0/legalcode.

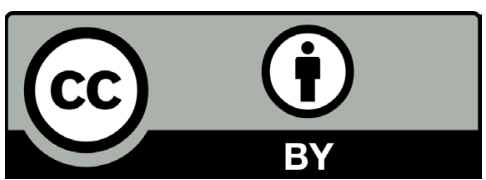

Entangled Religions 9 (2019) http://doi.org/10.13154/er.v9.2019.211-272
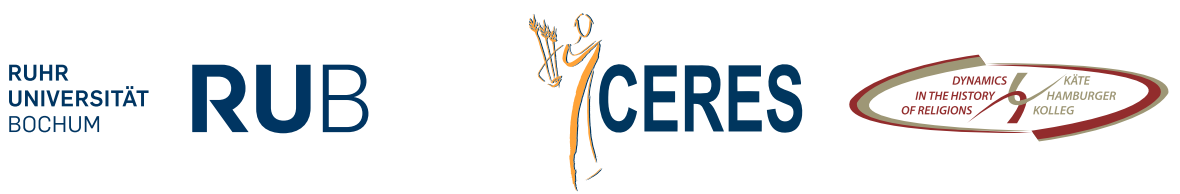

SPONSORED BY THE 


\title{
Towards a Multi-Religious Topology of Islam: The Global Circulation of a Mutable Mobile
}

\author{
MANFRED SING \\ Leibniz Institute of European History
}

\begin{abstract}
Narratives of the origins, the history, and the present state of Islam always entail spatial claims. Accordingly, Islam emerged in the Arabian Peninsula, spread over its so-called heartlands, and became a world religion. A common understanding inscribes Islam onto the Orient and opposes it to Europe, the Occident, or the West. Such spatial claims are faced with fundamental challenges and epistemological shortcomings because neither Islam nor space are naturally given, bounded entities. Rather, different historical actors and observers produce spatialized Islam. In this chapter, I challenge the notion that "Muslim space" is a useful analytical concept, and scrutinize the ways in which academic discourses inscribe Islam onto space and history. As an alternative, I propose a topology that understands the production of space as a multi-dimensional social process, including Muslim and nonMuslim perspectives at the same time. Thus, I delineate the topology of Islam as variegated, dynamic, and multi-religious from its inception. My argument is that Islam's trans-regional spread turned it into a polycentric, mutable mobile characterized by internal and external diversity. I further argue that images of Islam are an integral, yet often concealed part of European and Western knowledge production and self-understanding. Epistemologically, this perspective argues that the "Islamization of Islam" is nowhere better visible than in the spatial ramifications of discourses that marginalize, exclude, or obfuscate both the multi-religious experiences in Islamic contexts and the continuous presence of Islam in European history.
\end{abstract}

KEY WORDS Religious diversity; Islam; Judaism; Christianity; inter-religious entanglement; religious tolerance; space; Middle East; Europe; Africa; America; Asia

\section{Introduction}

From a Muslim point of view, space travelling was still only an individual experience back in the 1980s-although 230 Arab guests watched the launch of the spaceship in Florida that took the first Arab to outer space. Prince Sulțān b. Salmān Āl Sacūd (b. 1956), member of the Saudi royal family and the second son of today's King Salmān b. 'Abd al-'Azīz (b. 1935), participated in Space Shuttle mission STS-51-G in 1985 and helped to deploy the second communications satellite for the multi-national Arabsat programme. A crew member woke him up when they passed over Saudi Arabia for 
the first time, and, looking from the upper deck window, the prince enjoyed seeing the Eastern province floating above him. During the seven days' mission, he gave a guided tour through the spaceship which was beamed back to Arab television viewers on earth. He was the first astronaut carrying a small Qur'ān and dates from Medinaas his special meal-to outer space. Together with the Qur'ān, the prince took with him his pilot's licence and a prayer dictated by his mother asking God to take care of the travellers, which he recited during take-off (Lawton and Moody 1986).

Some 20 years later, the scenery had changed. Before the first astronaut from Malaysia was rocketed to the International Space Station (ISS) in a joint programme with Russia (2007), 150 religious scholars gathered in Malaysia to discuss the challenges of Muslim life in zero gravity. The scholars not only approved of the mission's aim to study the secrets of the universe, but also discussed how often to pray, considering that ISS circled the earth 16 times in 24 hours, how to face Mecca in orbit, and how to perform prayers. The National Fatwa Council finally approved of the suggestions worked out in the "Guideline for Performing Ibadah at the International Space Station (ISS)" (Fischer 2008; Lewis 2013).

This example epitomizes the growing ambitions of Arab and Muslim-majority countries in conquering outer space (Koren 2018). 25 Arab satellites have been launched since 1985. The interest in space technology not only serves military and economic interests and provides national prestige, it also has a high symbolic "Islamic" value, as it invokes the "Golden Age" of Muslim astronomers in the thirteenth to fifteenth centuries (Koren 2018; Guessoum 2013). Arab interest in modern space technology, which can be traced back to the nineteenth century, has created a cosmopolitan scientific community transcending Arab and Western boundaries, as Determann (2018) has shown. When, in 2010, the Qatar Exoplanet Survey discovered an extrasolar planet 500 light years away, it was named "Qatar-1 b." The Emirates Mars Mission, composed of a team of 150 solely Emirati engineers, is preparing to launch a space orbiter named Amal ("Hope") in 2020 that is to reach Mars in 2021, just in time for the fiftieth anniversary of the foundation of the United Emirates. The data of the Mars mission will be provided to 200 universities and research institutes all over the globe, according to the mission statement. The Emirates have also announced a "Mars 2117 project," aiming to establish the first inhabitable human settlement on Mars within 100 years (Determann 2018; Koren 2018).

Outer space has not become a "Muslim space"; nor has exoplanet "Qatar-1 b" turned into a Muslim planet through these activities. However, the scientific endeavours mark outer space as a legitimate area of Muslim-majority countries' interests. Heavy investment, international and local experts' planning, religious scholars' approval, popular use of TV satellites, and the interest of the scientific community give credit 
and legitimacy to enterprises which produce a symbolic space that connects the great Muslim past to the future of humanity. What these examples show is that the social "production of space" (Lefebvre 1974) involves a variety of human actions, from investment, planning, and popular use to claims of legitimacy. These actions attribute not only cosmopolitan, political, economic, and technical dimensions to a certain space, but also religious, emotional, and symbolic value. In a sociological sense, space is not just there to be inhabited by human beings, but its different dimensions are produced, changed, or destroyed by them.

From this starting point, I question the usefulness of terms such as "Muslim space" and "Islamic world" as analytical categories and take issue with the ways in which an Islamic identity is often inscribed onto space and history, thus implying Muslim sameness, boundedness, and groupness that are also connected with medieval, sectarian, or anachronistic beliefs. While places appear to be sheer facts, "our conceptions of them (...) are cultural constructions born of particular moments in time" (Green 2014, 556). As analytical categories, geographical models should not only be designed to enable "the tracing of commonality or connectivity" (ibid.), but also to understand "dynamic and mutable spaces of interaction that enable patterns of dissemination, circulation, or competition among ideas no less than commodities" (ibid., 558). Following Brubaker's and Cooper's (2000) critique of "identity," a distinction between a category of analysis and practice is paramount. Common parlance about Muslim places and a Muslim's feeling of belonging to a certain space must be kept separate from a view that analyzes the practices of identifying and categorizing places and spaces; otherwise, the strong or soft ways of "identitarian theorizing" (Brubacker and Cooper 2000,7) expound either that Muslim spaces simply exist or that they are multiple, fragmented, and fluid, in short, arbitrarily constructed. Although the critique of "Orientalism" (Said 1978) has cast "serious doubts on the assumption that an Islamic entity can be regarded as a world apart from, or even opposed to, the 'western world'" (von Oppen 2001, 277), scholars have mainly taken issue with the strong way of identitarian thinking by showing "the making and unmaking" of the "internal boundaries" (ibid.) of Islam; they left the external boundaries as well as the problem of soft, fragmented identities mainly untouched. My proposal is that we should start seeing what is termed as Muslim spaces or an Islamic world as inherently diverse and affected, if not created, by circuits of global knowledge production.

Drawing on Tim Unwin's $(2000,26)$ insight in his critique of Lefebvre (1974) that "to say that our ideas about space are socially constructed is something very different from saying that space is socially constructed," my approach revolves around two concerns. First, I aim to show that the space of Islam has often been described as predominantly Islamic by historical actors and various observers, thus neglecting, 
ignoring, or suppressing its multi-religious character. As a way out of this impasse, I secondly propose a topological approach, arguing that the debates about Islam created a trans-religious and transcultural space in which ideas about Islam circulated. What today is usually categorized as "Islam" is thus part of a historically growing knowledge production that has been circulating between believers, unconventional believers, and adherents of other faiths for a long time. On the one hand, the internal diversity of Islam offers overlapping areas with other religions; on the other hand, the space of Islam expands beyond the territories under Muslim rule. Therefore, the following considerations do not simply aim to attract attention to the position of Christians and Jews under Muslim rule (e.g. Courbage and Fargues 1997; Pink 2016) or to the mutual perceptions between Muslims and adherents of other religions (e.g. Waardenburg 1999) or to the common history of Muslims, Christians, and Jews in the Middle East (Sharkey 2017; Conermann 2017). Rather, the focus is on the production and circulation of knowledge that created a transcultural space and turned Islam into a "mutable mobile" ${ }^{1}$ (van de Kamp 2016, 1 and 3f.).

The problem of the spatiality of Islam is embedded in a wider epistemological context. The so-called "renaissance of space" in the humanities and social sciences has generated partly ambivalent and contradictory effects, especially with respect to Islam (Dörfler 2010). The combination with other "turns" (Bachmann-Medick 2006) has often led to a "spatialization" of society, culture, or religion-and thus implicitly caused a reification of space and its congruence with society. The negative effect of this impasse was nowhere more obvious than in relation to things Islamic because the renaissance of space reconfirmed the outworn, yet still powerful idea of "cultural regions" and "cultural spheres" (Frobenius 1898; Braukämper 2005). Not only has the notorious example of Huntington's (1996) "clash of civilizations" used the lame differentiation between Western, Christian, and European versus Oriental, Islamic, and Arabic. Huntington's critics also regularly fall short of a productive alternative understanding of space when they are content with showing that his essentialist association of space with culture is merely the result of a discursive power that needs and produces the view about cultural and religious clashes (Dörfler 2010, 44). These critics' concern with the spatial manifestations of power indirectly affirms the congruence of space, culture, and power. Thus, the idea of an Islamic incommensurability with modernity, the West, or other religions often creates a vicious circle in which "re-orientalizing orientals" speak for authenticity and "orientalizing orientalists" for difference (Al-Azmeh 2003, 26). This vicious circle results in an "over-Islamizing of Islam" (Al-Azmeh 1996) and deeply affects the construction and perception of space.

$1 \quad$ I thank Simone Schleper for drawing my attention to this paper. 
An obvious example that comes to mind is how space and its boundaries are arguments in popular debates about Islam in Europe among Muslims and non-Muslims alike. On the one hand, critics of Islam in Europe nowadays believe they are witnessing an "Islamization of Europe," while some of their opponents, demanding inner-Islamic reform, wish for an "Europeanization of Islam" (Berger 2013). The spatial imaginary behind this debate is the question of whether Islam, or which kind of it, belongs to and fits in Europe (Hashas 2013). On the other hand, Muslim scholars also grapple with the inverse question of whether Muslim minorities in European societies should follow a special version of Islam, designed for a diasporic situation, the so-called figh al-aqallīyāt ("the jurisprudence of the [Muslim] minorities"). This expression came into being in the 1990s and has sparked controversial debates among Muslim scholars (Albrecht 2016). Dividing the social world into different spheres is a problematic use of the classical Muslim tripartition between the so-called territories of Islam, war, and treaty (dār al-islām, dār al-ḥarb, and dār al-'ahd). The European Council for Fatwa and Research, the most influential institution dedicated to producing norms for Muslims in Europe, constructs an image of otherness for countries outside dār al-islām, even for third- or fourth-generation Muslims who no longer have any ancestors in predominantly Muslim countries (ibid., 118). Other scholars vehemently oppose this kind of dividing the world and societies. Some of them question boundary drawing on the grounds that the Islamic creed is the same everywhere; others explicitly relocate dār al-islām in the West because its secular societies guarantee religious freedom (ibid., 117-127).

This example also brings to the fore that exclusively Muslim spaces are an exception-either because the Islamic character of a space is only one spatial dimension or because there exist opposing claims. Why, then, is the talk about Muslim space-with its "bloody borders," according to Huntington (1996, 254) - so pertinent? Why can an Arab grocery store be perceived as a Muslim place in Berlin but not in Cairo? Can Europe be regarded as a Muslim space in the same sense as the Middle East? Are European cities Muslim spaces and, if so, for whom? In other words, how do we-believers, observers, critics, or researchers-create and perceive, make and unmake Muslim spaces?

In order to approach these questions, it is necessary to unpack the dimensions involved in the production of space and Islam. Space obviously is a complex, dynamic, and relational configuration, not simply the geographical background of society (e.g. Löw 2001; Günzel 2017). Actors perceive, understand, and imagine space, while their own actions as well as their social relations produce space and give meanings to it. Rather generally put, elites invest in space, specialists design its future prospects, and people use it. Religiously marked space as well as religious architecture share in the material, cognitive, symbolic, and semiotic features that constitute social space (Knott 
2005; 2009). The production of religious space involves believers and non-believers with differing, if not opposing, interests and affects their perception, behaviour, devotion, and respect for such a space. A financial investment, purposeful planning, a material shape, a symbolic meaning attached to its architecture and an understanding of its symbols, expressed in a certain comportment, bring religious space into being, while at the same time regulating and controlling the flow of people and goods inside and around it. A speciality of religiously connoted space is that it can be impermanent, transnational and can change or lose its function. Religious space can be a playground for conflicting claims, but also for inter-religious sharing. Whether actors openly claim a space to be Christian, Muslim, or multi-religious, and whether they try to change its identity or leave it open, depends on the physical availability, symbolic importance, and forms of legitimacy at play (Weltecke 2012).

In early modern times, an understanding of "cultural geography" was not yet present; it came into being in the nineteenth century (Frobenius 1898; Braukämper 2005). The term "Islam" has also only come into popular use since the nineteenth century and stands for an academic convention with its own history; it is used to categorize a form of intra-religious diversity under one umbrella term and to distinguish it from other forms of intra-religious diversity. In the past, Muslim heresiographers would not have considered every branch of what researchers today call Islam "Islamic" (see van Ess 2011); Christian Europeans, who might not have considered themselves as Christian Europeans in the literal sense, did not even use the term "Islam" before 1697 in French and before 1818 in English (Tolan et al. 2012, 14f.), and most of them thought of Muhammad as a "Turkish prophet" and understood Mohammedanism as a "Christian heresy". Although the term "musulman" and "moslim" can be found in French and English sources from the sixteenth century onwards, neither peoples nor spaces were Islamized. The terms mostly used for Muslims referred to their ethnic belonging (like Arabs, Turks, Persians, or Moors) or were of Biblical origin (like Hagarenes, Ishmaelites, or Saracens) (ibid., 12-17). Ottoman travellers were often categorized as Orientals or Levantines, "which could designate any merchant from the east, including Greeks, Jews, Armenians, Maronites, Persians, Turks, or Arabs" (Krstić 2015, 685).

The following chapter tries to describe the space of Islam from a fresh perspective by carving out its multi-religious topology. Firstly, I give an overview of the terminology that is usually used to inscribe Islam onto space and history. I distinguish three approaches-geographical, cultural, and trans-local/national/regional-in the academe and highlight their underlying premises and theoretical difficulties. My criticism mainly aims at showing that these terms tend to homogenize existing differences with regard to places, peoples, and cultures. Secondly, I propose the concept of a multi-religious topology of Islam as an alternative for a different understanding of Islam and its 
location. The concept does not only mean that religious diversity and relationality are a permanent given of Islamic contexts; it also argues that the circulation of knowledge created a transcultural space of Islam. The multi-religious topology of Islam also involves actions and perceptions of non-Muslims and even circumstances in which Muslims were not personally present. As will be shown, the topology of Islam encompasses a global sphere, ranging from debates about Islam, violence, and tolerance in the ages of the Reformation and Enlightenment in Europe to debates about the treatment of Native Americans, religious freedom, and slavery in the Americas.

What is said here could most probably be said, with slight variations, about other religions as well and seems, in this respect, to verge on a platitude. However, the following remarks are not only directed against the "over-Islamization of Islam" (Al-Azmeh 1996), but also against a fetishism of geography and a one-dimensional understanding of spatialized-national, regional, cultural, or religious-entities. They speak back to the "epistemic violence" (Spivak 1993, 76) represented by "the remotely orchestrated, far-flung, and heterogeneous project" (ibid.) that constitutes the colonial subject as the Other and obliterates the trace of this Other. Following the anthropologist and historian Fernando Coronil $(1996,57)$, the overall aim of this chapter is to challenge

conceptions of the world, which (1) separate the world's components into bounded units; (2) disaggregate their relational histories; (3) turn difference into hierarchy; (4) naturalize these representations; and thus (5) intervene, however unwittingly, in the reproduction of existing asymmetrical power relations.

In this respect, the following considerations underline both the multi-religious experiences in Islamic contexts and the continuing presence of things Islamic in the European imaginary. Moreover, this chapter puts the existence of shared sacred places under Muslim rule-and the controversial discussion about this phenomenon

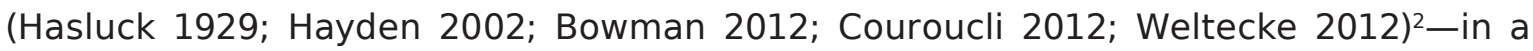
wider frame. By underlining differing spatial practices in multi-religious landscapes, I further challenge the trope of a violent Islam inimical of the religious Other. Instead, the history of Islam will be described as a continuous negotiation with religious diversity that was linked to inclusivist as well as exclusivist practices from its very beginning. ${ }^{3}$ The opposing practices can be better understood against the background of crossconnections, interdependencies, and shifting power relations between Muslims and non-Muslims in various places.

2 See also the introduction and Glenn Bowman's article in this volume.

3 For more details, see my article "Where Do the Multi-Religious Origins of Islam Lie? A Topological Approach to a Wicked Problem" in this volume. 


\section{Where and What is Muslim Space?}

In academic discourse, three different yet inter-related categories to locate Muslims in space can be distinguished. Firstly, (pseudo-)geographical terms like "Orient," "North Africa," "Middle East," "Central Asia," or "Southeast Asia" are often used to outline some of the "central" lands in which Islam has spread since its beginning and in subsequent centuries. Secondly, cultural-religious terms like "Islamic" and "Islamicate" civilization or "Muslim (Ottoman, Mughal) empire" are meant to designate the unity of Muslims, sometimes in far-flung lands, either in an idealistic sense (comparable to Muslim expressions like umma or dār al-islām) or in a political sense (like in the case of Indian Muslims' support for the Ottoman caliphate in the early twentieth century). Thirdly, different "trans-" perspectives-from "trans-local" to "trans-national" and "trans-regional" to "trans-cultural"-highlight Muslims' connections across boundaries. This last approach is a result of a growing unease with conventional area studies-an unease scholars in various fields have felt in the wake of globalisation and at the end of the Cold War since the 1990s (Mielke and Hornidge 2014). Whereas conventional Area Studies focused on fixed physical or cultural territories, demarcated by clear political or cultural borders, a "post-Area Studies perspective" questions these boundaries and understands spatiality not as a given but as shaped and re-shaped by human experience, action, and imagination. It looks at the transgression of boundaries, processes of entanglement, and the negotiation of space as well as at various forms of mobility, dynamism, and at networks (ibid., 18f.).

Each of these designations of Muslim space has its blind spots. Geographical and cultural-religious ascriptions designate space as a rather stable entity, mostly ignoring the contingency of the underlying terminology. The "trans-" perspectives, in contrast, focus on interconnectedness and "contact zones" (Pratt 1991) and tend to dissolve complex social, religious, economic, and political structures into channels, routes, and networks through which people, goods, and ideas flow, without being able to say much about the specific nature of the social structures behind these flows.

Geographical terms suffer the most from the limitations of a container perspective on space. They describe geological, economic, cultural, or religious characteristics of the areas under study as if they explained the existence of Muslims in these areas. In a recent handbook article, Escher (2016) deals with the "geography of the Islamic space," yet largely focuses on 28 countries of the MENACA region (Middle East, North Africa, and Central Asia) and their characteristic, "semi-arid" features. As this region comprises only half of all Muslims worldwide, he is well aware that the "Islamic space" could (or should?) also include Southeast Asia and Sub-Saharan Africa (ibid., 12, 17). However, these regions, as well as the existence of Muslims in Europe and America, are dealt 
with in separate chapters of the same handbook. This arrangement implicitly treats the MENACA region as the primordial Muslim space, whereas all other regions are only marked by the presence of Islam and Muslims "in" them, meaning that they obviously do not represent inherently Islamic spaces. The focus on an "Islamic geography" in the MENACA region allows elucidating some common features with regard to agriculture, nomadism, urban development, water policy, and "problematic natural resources," such as oil and gas (Escher 2016, 18-33); yet it necessarily remains unclear how the socio-economic features of this Islamic space can explain "the socio-political dynamics" (ibid., 33-40) and a "geography of violence" (ibid., 37-40) in this Islamic space. It seems questionable how the identified elements of and in the Islamic space are connected with each other, in how far these elements are historically connected to the emergence of Islam and its development, and how closely geography and religion are generally interrelated. Singling out 28 countries because of an arbitrary criterion-the historical depth of Muslim presence and the high Muslim percentage in the present-neither explains the presumed "Islamic" character of this area nor the spread of Islam beyond this area with its presumably characteristic features, from the existence of Tatars in Poland and the Baltic region for 500 years (e.g. Svanberg/Westerlund 2016) to the conversion of indigenous peoples in Australia and New Zeeland in more recent times (Onnudottir et al. 2012).

Even with regard to the MENACA category, the question arises which countries should be placed inside the category. Why is Pakistan included, but India-with numerically nearly as many Muslims as Pakistan-excluded? Why is the predominance of Muslims a criterion while Indonesia, the country with the most Muslims worldwide, is not part of the region? Why does Northern Africa belong to a region extending to Fergana Valley and is set apart from the rest of Africa while nearly half of the latter's population is Muslim? This separation proves that Islam in Africa is still perceived as being "rather peripheric" although "Muslims in Sub-Saharian Africa form one of the largest bodies of Islam worldwide, second only to the Indian subcontinent" (Loimeier $2009,287)$. The MENACA category also suggests that Islamic space and the MENACA area as a whole are somehow synonymous, in spite of various religious minorities, such as Christians of Eastern and Western denominations, Jews, Zoroastrians, Bahā'īs, or Yezīdīs.

To be sure, MENACA is not only an acronym used by scholars, but also by the United Nations (Escher 2016, 12; United Nations 2018). The five UN regional offices include and exclude Arab and Muslim countries in a somewhat arbitrary manner. The Economic and Social Commission for West Asia (ESCWA) encompasses 18 Arab countries in Asia and North Africa, but not Algeria, Morocco, Mauretania, Sudan, Djibouti, and the Comoros, all of which are members of the Arab League. These six states are part of the regional 
office of the African group (ECA), which also includes the other three Arabic states of North Africa (Libya, Tunisia, and Egypt). Turkey and Iran are part of the regional office for Asia and the Pacific region (ESCAP), which also includes the Central Asian and South Asian states with substantial Muslim populations and extends from Russia over China to New Zeeland. Israel is neither part of "West Asia" nor of "Asia and the Pacific", but is treated as part of the regional office for Europe (ECE), which also includes Central Asia (Kazakhstan, Kyrgyzstan, Tajikistan, Turkmenistan, and Uzbekistan). The only regional office that does not include any Muslim-majority state is the one for Latin America and the Caribbean (ECLAC). ${ }^{4}$

This allocation of contemporary Muslim-majority societies to different regions is far from clearly defined. Moreover, in the MENACA acronym lurks the pseudo-geographical term "Middle East" that brings with it a package of political, cultural, religious, and historical assumptions (see the discussion in Bonine et al. 2011). While other fields in academia are designated with more neutral terms, pertaining to continents-e.g. African or South Asian Studies-, this has not happened with "Middle East" studies, whose region is said to lay somewhere in between. The terminology remains a mirror of European interests and a relic of Euro-centric nomenclature (Khalidi 1998, 74). While its boundaries are unclear, a relation to Islam is suggested but not clearly expressed. Following Davison's (1960) recommendation to make the "damage-limiting best" (Green 2014,562$)$ out of this category, Green $(2014,557)$ has pointed at the possibility that scholars might agree on arbitrary limits of the "Middle East" and redefine the category "for each and every analysis". For the similar term "Near East"-a term mainly used in French and German-an "epistemological crisis" (Reinkowski 2017) has been diagnosed, especially with the mass migration over the Mediterranean Sea following the Arab revolts in 2011 . The region has come too close to many Europeans, since "near" originally meant close enough for Europeans to reach it, but far enough away from "them".

With regard to the formerly very prominent notion of the "Orient," the same problem of imprecision holds true, since the region has been perceived just as small as the "Near East," or as a synonym for Asia, or as including parts of Africa. Edward Said pointed out in the late 1970s already that the production of images of the "Orient"by connecting it to Islam, Arabs, violence, and promiscuity-was a "Western style for dominating, restructuring, and having authority over the Orient" (Said 1978, 3). Astonishingly enough, his-for the most part valid-critique, concerned with the de/ construction of the binary of Orient and Occident as it was, did not breathe a word

4 This office, however, promotes the Forum for East Asia-Latin America Cooperation (FEALAC), in which Indonesia, Brunei, and Malaysia are engaged, but no other Muslim-majority country from "East Asia." 
about the Ottoman Empire and its ambivalent position beyond this binary (Bryce 2013). For centuries, the Ottomans were present in Europe, had a vast number of Christian subjects, and could hardly be subsumed under the category of the "Orient," although they were certainly depicted as the "Other" in European discourses throughout the centuries (Konrad 2011). Thus, Said avoided making sense of the fact that the Ottoman Empire was deeply involved in the power game of European states for centuries and represented a third entity, situated beyond the simple dichotomies of Orient and Occident, Islam and Christianity.

With this example, we have come to the second category, cultural geography. It is controversial whether and for what epoch we can speak of a distinct Muslim, Islamic, or Islamicate civilization. Aydin (2017) has recently pointed out that the idea of the "Muslim world" was only coined in the nineteenth century by European colonialists and then adopted by Muslim elites to counter racism against Muslims. From the seventh to eighteenth centuries, the idea of Muslim solidarity practically proved "politically impotent" (Aydin 2017, 15), since the Muslim political experience was characterized by "multiplicity, contestation, and change, leaving the idea of the Muslim world to emerge later, alongside the later civilizational narrative of the West" (ibid.). In contrast to this argument, Ahmed (2016) tried to show that Islam in "the Balkans-to-Bengal complex" (ibid., 74) can be conceptualized as "the co-herence of contradictory norms in the lived 'religious' reality of Muslims" (ibid., 46; emphasis in the original). Thus, the differing ideas that Muslims expressed in philosophy, Sufism, poetry, art, and the celebration of wine consummation seemed to stand in stark contrast to Qur'ānic and Sharī'a prescriptions. That Ahmed takes "the unity in diversity" of the Islamic worldview and experience as his starting point makes it rather challenging to come up with a precise definition of Islam, yet he remarks that contradictory ideas and norms were a commonplace phenomenon in Islam from 1350 to 1850. For him, this "Balkansto-Bengal paradigm" marks "demographically, spatially, and temporally an (if not the) historically major paradigm of Islam" (ibid., 82; emphasis in original) before the European encroachment into Islamic lands in the nineteenth century. In a similar way, Abu-Lughod (1989) already spoke of a "world system" prior to European hegemony for the thirteenth and fourteenth centuries; in Lapidus's (1989) view, a "world system" of Muslim societies existed up to eighteenth century.

The attempt to determine an Islamic space and underline its historical importance is directly inter-connected with the much-debated question of where Islam stands in relation to world history (Abu-Lughod 1989; Lapidus 1989; Eaton 1993; Hodgson 1993; Voll 1994; Clarence-Smith 2007): How does Islam relate to the emergence of the modern world system? Can it be seen as a "world civilization" in its own right? When was it integrated into the European hegemonic global system, developing at some 
point after 1500 ? Reichmuth (2000), discussing the different approaches, shows how this debate is related to other theories and grand narratives, from Hodgson (1974) to Wallerstein (1980-1989) and Braudel (1979/80) to Frank (1998). These authors hold completely different views about Islam. Hodgson understands the Islamicate world as key mediator between Asia and Europe, Antiquity and Modernity; Wallerstein does not treat Islam as a socially, economically, or politically important unity; Braudel partially integrates Islam into his narrative in an ambivalent manner; and Frank subsumes Islam under the category of an Asian age in world history/economy. Therefore, Reichmuth $(2000,81 f$.) is sceptical whether it is adequate to speak of different interacting "world systems" and of a special "Islamic world system" in a cultural and economic sense. He remarks that Muslims' economic activities, at least since the seventeenth century, were too much entangled with South Asian and European spaces to make the expression of a coherent Islamic world economy meaningful. Even expanding religious networks, spanning several regions, are no indication for a cultural, discursive Islamic world system. Rather, giving up on the idea of a coherent system leaves room for multiple and contradictory relations, according to Reichmuth (ibid., 82).

Like the geo-political nomenclature, the geo-cultural terminology, which tries to ascribe a cultural (and economic) sphere to Muslim activities, suffers from the deficiencies of the container perspective. The cultural boundaries of a term like "Islamic civilization" are as unclear as the geo-political boundaries of the "Middle East." Not only does it homogenize cultural-religious internal differences when it calls a civilization "Islamic." It also has little to say about Muslim minorities with possibly different traditions outside of Muslim empires or Muslim-majority societies. From a cultural perspective, Muslims in peripheral Islamic areas in Africa, Asia, Europe, and the Americas dwell in the "wrong" places, similar to Muslims outside out of the geopolitically constructed MENACA region. In what sense are these Muslim minoritiessuch as the Moors in Sri Lanka, the Rohingya in Myanmar, or the Cham in Cambodiapart of "Islamic civilization" and not also, or even more so, of South Asian cultures? Is it not impossible to understand diverse local traditions from an exclusive Islamic point of view, such as the approximately 300-year-long tradition of women's mosques (qingzhen nusi) and their female religious leaders (nu ahong) among the Chinese Hui (Jaschok and Jingjun 2000), or the zār-cult in Ethiopia, Sudan, and Egypt, or the bori-spirit possession cult in Hausaland, and the East African pepo-cult (Loimeier 2013, 33)? A way out of this impasse seems to be the terminology of the "world of Islam" or an "Islamic world," which is, for example, used in the possibly most comprehensive encyclopaedia about Muslims around the globe to date (Esposito 2009). In its claim to be comprehensive, it includes entries even about the tiniest Muslim minorities. However, the problem that arises from this perspective is that the "Islamic world" corresponds to the globe. Not 
only do Muslim-majority societies make up the 'Islamic world', but Muslim minorities in secular societies or regions with different hegemonic cultural or religious traditions are also part of it. In what sense can these diverse spaces be subsumed under the heading of an "Islamic world"?

A different way of looking at blurry, porous boundaries are trans-national, transregional, trans-cultural, and trans-local perspectives that are interested in migration, mobility, and the interconnectedness of political, economic, cultural, and religious phenomena (Budde et al. 2006; Welsch 2017; Freitag and von Oppen 2010; Mielke and Hornidge 2014). In these approaches, spaces such as the Mediterranean, the Indian Ocean, the Black Sea, the Silk Roads (Frankopan 2015), and the trans-Saharan trade routes have drawn new scholarly attention in recent years because they are placed at the crossroads of continents, "civilizations," and religions. Green (2014) has proposed to "disaggregate and enlarge" the Middle East into three intersecting arenas: a Mediterranean arena, an inner Asian arena, and an Indian Ocean arena. Although these arenas also run the risk of being reduced to a container understanding of space, the new scholarship indulges in them to highlight forms of exchange across boundaries. Already in the monumental work on the Geniza documents, Goitein (1967-1988) portrayed Jewish communities of the Arab world as an integral part of a "Mediterranean Society." Putting Islam at centre stage also helps to explain how, under Muslim rule, technological toolkits from the Romans, Persians, Indians, and Chinese-such as water management, writing and book technology, as well as mathematical expertise-were acquired and refined, and helped to bring about (European) modernity. The ensuing decline of the formerly dynamic region between 1500 and 1800 is then explained not by drawing on cultural (Islamic) factors but from an "ecohistorical perspective," which underlines the limitations in man power and natural resources compared to other regions of Eurasia (Burke III 2009 and 2012).

The interconnectedness of various spaces can be put to work in different ways. Regarding the Mediterranean region, some scholars underline its distinctiveness and connectivity for more than two millennia or since pre-history (Horden and Purcell 2000; Abulafia 2011); others stress the multi-directionality of migrations from and to different shores and rather speak of "Mediterraneans" (Clancy-Smith 2010); some question whether there is a distinct and coherent history of the Mediterranean and rather argue for a "coherent eastern Mediterranean world" (Holmes 2012, 13f., 23-25); still others focus on the mutual impact between the French Revolution, the Ottomans, and the southern rim of the Mediterranean basin (Lorcin and Shepard 2016, Firges 2017). Similarly, a focus on the Indian Ocean tries to capture the trans-local, multi-directional flows of people, goods, and ideas around the rim of the ocean and place them in Islamic as well as global history (Conermann 1998; Deutsch and Reinwald 2002; Freitag 2003; 
Freitag and von Oppen 2010). This approach can also be applied to Ottoman relations to South Africa (Kavas 2007) or to Islamic transatlantic contexts in Brazil and South Africa (Gebauer and Husseini de Araújo 2012). Focussing on techniques of mobilisation or on network analysis can further help to explain the different ways in which political Shiism has recently spread in Cambodia and Venezuela (Bruckmayr 2018), how actors create "transnational Shia communal spaces" and networks in London (Scharbrodt 2018), how Salafism was located among the Oromo Muslims of Ethiopia (Østebø 2012), and why the recruitment of the self-proclaimed "Islamic State in Iraq and Syria" has been rather successful in Trinidad (Graham-Harrison and Surtees 2018).

What transpires from the three-geographical, cultural-economic, and transregional-perspectives is that a "Muslim world" is envisioned by academic researchers with different agendas. The mutability of geographical models not only reveals the varying interconnections of the same spaces; it also shows that different spatial models "suit different questions and methodologies, not to mention different periods" (Green 2014, 557). The geo-political construction of Muslim space can easily exclude half of all Muslims and locate them somewhere in an ill-defined outside. A cultural geography that is concerned with locating bygone Islamic civilizations can similarly fall short of taking into account the experiences of Muslims beyond the borders of former empires and locate them in ill-defined diasporas. It further has little sense for the facts that (1) "Islamic civilization was a big house" (Sharkey 2017, 16), produced "not only by and for Muslims" (ibid.) but also by non-Muslims, (2) that "Muslim, Christian, and Jewish populations in the Middle East historically exhibited considerable internal diversity" (ibid.), and (3) that Middle Eastern societies were never monolithic and static (ibid., 17). Trans-regional and trans-cultural perspectives that are more interested in the interconnectedness of places and peoples than in carving out a distinct Muslim space implicitly tend to make the "in between" position of Islam their raison d'être. These kinds of studies can foster forms of fragmentation with regard to Islam. When Islam is seen as entangled in trans-local/national/regional contacts, the container of a Muslim space is dissolved into contact zones; yet these zones appear to be rather exceptional in relation to a traditional understanding of Islam. For example, the historiography of the Ottoman Empire already suffers from a fragmentary character along regional, national, ethnical, tribal, or epochal lines and faces "difficulties in bringing together the work of historians from different local realities" (Lafi 2014, 246). Therefore, the long history of the Ottoman Empire, with its European and extra-European parts, finds different expressions in national, comparative, and global historiographies; its integration into the periodization and research interests of European historiography poses a challenge that is far from solved (Helmedach et al. 2013). 
It is not the intention of the preceding discussion to proclaim the relativity of space according to differing agendas. Rather, the aim is to underline the relational nature of spaces that are termed as "Muslim spaces." Islamic communities in Western cities are not only incorporated in a changing material and sociological landscape; they are also grounded in trans-local and trans-national connections and reflect personal as well as gendered experiences, all of which produce changing modes of visibility, othering, resistance, adaption, and self-perception (Bendixsen 2013). In a mobile world, religious and confessional identities "cannot be taken as a deep-rooted social reality but as having been actively produced, and reproduced in an on-going process" (Peleikis 2001, 400). Migration can directly affect and change the ritual practices, performance, and embodiment of religious identities (Langer et al. 2005). The re-negotiation of religious identities can take place "on a translocal and transnational scale in the interaction between local, regional, and national actors" (Peleikis 2001, 400), thus between processes that tend towards a "territorialisation of identities" in the home country and a "de-territorialised social space" that binds a physically dispersed community together, as Peleikis (2001) shows with regard to groups from multi-confessional Lebanon. This paradox effect is also visible in the heterogeneous Shiite communities in Germany, "highly diversified in terms of their linguistic, national and ethnic backgrounds and ritual practice" (Langer and Weineck 2017, 216), as they show considerable differences in the representation and reproduction of their faith (ibid.). The argument, developed from here in the rest of this paper is that a topology of Islam must grasp this dynamism and diversity, which means that the sense of what it means to ascribe "Islamicity" to a community and its location is subject to ongoing negotiations between its members as well as other Muslims and non-Muslims.

\section{Towards a Multi-Religious Topology of Islam}

The attempt to carve out the multi-religious topology of Islam rests on the idea that religious diversity has a direct imprint on spatial practices and vice versa. The following description connects the multi-religious dynamism that is visible in (changing) Muslim practices, norms, and institutions with historical inter-religious encounters and mutual perceptions as well as with non-Muslim discursive uses of Islam, the European knowledge production and transcultural circulation of ideas about Islam. The term "topology" describes this relational understanding of space and differs fundamentally from "topography," in the sense that the latter represents a mere physical location (Günzel 2017, 110-140). Topography rests on a container understanding of space, according to which two objects cannot be in the same place at the same moment; with 
this view, places or people residing in them can also be ascribed a singular identity of cultural, national, or religious provenience. In contrast, the topology of a location can change over time because of its relational and dynamical nature, even if its topography stays the same. For example, the perception of the same place changes in times of war and of peace (ibid., 127). In the same way, different perspectives and practices are connected with places and spaces shared by members of different faiths. Perspectivity and spatiality also apply to institutions that facilitate religious encounters and boundary-drawing. Thus, the institution of the dhimma, a contract of protection (and submission) of non-Muslims under Islamic law, went hand in hand with differing practices, depending on time and place; historically applied to a growing number of religious groups, it could even include simultaneous forms of tolerance and intolerance (Noth 1978). The same ambivalence holds true for the treatment of non-Muslim groups under the so-called Ottoman millet system, which was far from a comprehensive system prior to the eighteenth century (Masters 2001), but became increasingly differentiated in the nineteenth century and encompassed seventeen different confessions prior to World War I (Pink 2016, 495). Instead of focusing on the "status" of dhimmi minorities under Muslim rule, an alternative view is to trace the non-Muslim "responses" to Muslim rule, which opens up a "matrix of interfaith relationships" (Simonsohn 2017, 362). As soon as non-Muslims responded in favour of the possibility of participating in Islamic institutions, they blurred traditional communal boundaries and triggered a spectrum of further "responses from various parts within non-Muslim communities" (ibid., 363) but also Muslim reactions. Regarding the question of how the "Ottomanization" of newly conquered lands worked, Hadjikyriacou (2016a; 2016b) suggests focusing on multi-layered encounters in "contact zones" (Pratt 1991) and leaving behind statecentric approaches as well as the periphery-centre binary. The case of Cyprus from the seventeenth to nineteenth centuries reveals that-while there was "no inhibition about empowering non-Muslim locals" (Hadjikyriacou 2016a, 250)-the rise and fall of individual actors of Christian background was characterized by fluid confessional boundaries as well as inter-Christian conflicts, but also, more generally, by social dynamism as well political instability (Hadjikyriacou 2016a; 2016b).

A focus on multi-religious dynamism also helps to grasp the mutual perceptions that circulated between Muslims, unconventional Muslims, and non-Muslims. In this respect, it is necessary to think together the "internal" diversity of Islam and the "external" religious diversity in an Islamic environment, which seems to be rather challenging for scholars of religious and Islamic studies; they often take refuge in the problematic concepts of "orthodoxy and heterodoxy"5 (e.g. Langer and Simon 2008;

5 As there are no equivalent expressions in Arabic, many scholars denounce the terms as Eurocentric interpretative categories; yet as Langer and Simon $(2008,274)$ state, "even those who find the 
Dressler 2010). On the one hand, tropes from different religious traditions often appear to be intermingled and integrated into one communicative unity, which does not allow clearly distinguishing between Jewish, Christian, and Muslim elements, especially in the studies of Qur'ān and early Islam-in spite of (later) differences. ${ }^{6}$ On the other hand, Sunnī, Shī'ī, and Șūfī expressions of Islam and its regional, popular, and legal variants ${ }^{7}$ are sometimes so divergent and ridden with conflict that it also seems challenging to understand them as one religious tradition-even more so if we consider highly non-conformist groups that developed in an Islamic environment, such as Alawites (Nușayrīs), Durūz, Yezīdīs, Ahl-e Ḥaqq, Sikhs, Bahā'īs, and Aḥmadīs. The meaning of Islam has been permanently re-negotiated by a variety of social and religious groups, some of whom were considered Muslim by their co-religionists, while others were seen as dubious or even un-Islamic. When we start treating "Islam as an ever-changing set of arguments rather than a panoply of beliefs and practices" (Bashir 2018, 25), processes of negotiation about Islam also include decidedly non-Muslim groups who shared a common space with Muslims. As Waardenburg (2004) has shown, Muslim authors often treated Islamic sects and non-Muslim religions together in heresiographic works-with changing classifications. ${ }^{8}$ Terms such as milla or firqa, although used inconsistently, were applied to Muslim as well as to non-Muslim groups. In his Kitāb ta'rīkh al-Hind, alBīrūnī (d. 1048) not only gave a comprehensive insight into Hindu practices, folklore, cosmology, religion, and philosophy, but also compared them to existing Șūfī practices to make them understandable to his readers in spite of fundamental differences (ibid., 228).

Thinking about the multi-religious topology of Islam therefore involves rethinking how the very idea of Islam has been made, unmade, and remade but also materialized, manipulated, and stylized since its early years. In this respect, a main assumption is that religious flows are not unidirectional, emanating from a centre to the peripheries, but that a polycentric cartography of the sacred is shaped by pilgrims, scholars, travellers, and tourists through knowledge production, mobility, and different media.

term problematic, or declare its use inappropriate continue to apply it. Sometimes orthodoxy is avoided but tacitly implied while heterodoxy is openly addressed. As an indication of its somewhat questionable status in an Islamic context it is a common practice to put it in quotation marks."

6 This is further elaborated in my article "The Location of Religious Diversity at the Origins of Islam: A Topological Approach to a Wicked Problem" in this volume.

7 Scholars of Islamic studies not only differentiate between an Arab, Persian, Turkish, Indian, Indonesian, African (etc.), and European Islam but also between "orthopraxy" and "folk Islam" and the different, traditional legal schools.

8 Waardenburg discusses Ibn Ḥazm's (d. 1064) Kitāb al-fiṣal fí l-milal wa-l-ahwā' wa-l-nihal, Aḥmad Sharastānī's (d. 1153) Kitāb al-milal wa-l-nihal, and Abū Ma'ālī's Kitāb bayān al-adyān (1092). For greater detail on Muslim heresiography, see van Ess 2011. 
The topological focus on "exchange" and "circulation" brings to the fore that practices, objects, and ideas "transform in the course of their displacement and become 'mutable mobiles'" (van de Kamp 2016, 4). Drawing on this consideration, I suggest that there is not one Islamic form but multiple ones, and that processes of translation, addition, and appropriation "take different shapes but coexist in one particular space" (ibid., 5), especially when they come into contact with a multiplicity of other religious practices, ideas, and objects. Sketching historical examples in various settings will demonstrate how the polycentric dynamism of Islam, its expansion in space, and its encounter with various "Others" are inter-connected.

The history of the expansion of Islam is marked by attacks, retreats, losses, and re-conquests as well as by movements of religious renewal that emerged from different places and involved different tribal, ethnic, and religious groups. Although the emerging multi-religious topology of Islam marked the co-existence of a vast variety of religious "Others," it did not necessarily equate with a particular Muslim tolerance for the plurality of understandings of Islam or for a pluralist society, as already mentioned. A peculiar story tells how Muslim pressure forced the so-called "pagans" of Harrān-a strategically important town ${ }^{9}$ close to today's Şanlıurfa, on the border between Turkey and Syria-to become "people of the book" (ahl al-kitāb). ${ }^{10}$ According to a Muslim source, caliph Ma'mūn (ruled 813-833) tried to force the Harrānians to convert to Islam or at least adhere to a book religion. Under this pressure, they claimed to be "Ṣābi'ūn," a name of unclear origins for an undetermined group that was mentioned in the Qur'ān $(2: 62,5: 69 ; 22: 17)$ alongside Jews and Christians as "believers" and that, therefore, had the right to be treated as "people of the book." Although it is unclear whether the story is true or whether Șābi'un had already lived in the region prior to the reported event (Green 1992, 106), reading the source suggests two points: First, the boundaries between what was termed "paganism" and "religion" were fluid at that time. Second, acceptable religiosity was created by an interaction between a Muslim ruler's demand and the non-Muslims' smart response.

Historically, non-Arabs did not become Muslims overnight after the Arab conquests of the early centuries, and when they converted, they were obliged to enter into a relationship with an Arab patron and remained second-class Muslims (Crone 1991). For quite some time, a rather tiny ruling Muslim minority was confronted with a non-Muslim majority in the lands under Muslim control. From the sparse data available, Bulliet

9 The inhabitants played a vital role in the transmission of Greek philosophy and science. The Umayyads favoured the town and transferred a school of medicine from Alexandria to Harrān; caliph Marwān II (ruled 744-750) even made Harrān his capital in 745 (Bosworth 2003).

10 According to Al-Azmeh $(2014,183)$, the inhabitants managed to adhere to their pagan cult well into the tenth century, in spite of Christian and Muslim disapproval. 
(1979) has concluded, based on a statistical evaluation of biographical dictionaries, that conversions might have taken place in different regions with different speed and that it sometimes may have taken several centuries before the population in the conquered lands adopted Islam. Given this approach, roughly half of the population in Egypt might have considered themselves Muslims 300 years after the Muslims' conquest, while by the thirteenth century, the share may have risen to 90 percent (ibid., 92-113). Kafadar $(1995,76)$ describes the people of Anatolia and South Eastern Europe up to the fifteenth century as "metadox"- "a state of being beyond doxies, a combination of being dox-naïve and not being doxy-minded, as well as the absence of a state that was interested in rigorously defining and strictly enforcing an orthodoxy." Individual Jewish and Christian subjects of Muslim empires were able to hold high ranks in the administrations in several instances; although they were excluded from the military service, ${ }^{11}$ they could pursue their interests in trade, money lending, medicine, the sciences, and arts and craft, often without restrictions and alongside Muslims (Pink 2016, 493).

Irrespective of the sack of Baghdad (1258), the Mongols' conquests helped to spread Islam to new spaces between China, Central Asia, India, and today's Russia and Poland. The Mongols' advance produced a common space of interaction, imagination, and destruction and intensified the trans-regional traffic of goods, travellers, and refugees, also creating "a single disease zone" (Jackson 2017, 382; 405-408) which caused the spread of the Black Death between China and Europe in the mid-fourteenth century. Chingis Khan (d. 1227), recognizing "the disruptive potential of competing religions," decreed absolute religious freedom-"probably the first law of its kind anywhere in the world"-and exempted religious institutions from taxation (Weatherford 2004, 69). The conversion of Ghazan Khan in 1295 and other Ilkhanite rulers to Islam without privileging their new faith ${ }^{12}$ had repercussions on Muslims within and beyond the Mongolian empires and changed the organization of things Islamic in a political, social, cultural, and religious sense (Jackson 2017).

In the Ottoman Empire, Christians could be long-distance merchants, slaves, subjects, or vassals, and their respective social positions were based on a complex mosaic of regulations throughout the centuries. The privileged, extraterritorial status

11 The first serious attempt to draw Christians into the army happened in the Ottoman Empire in 1835 , but compulsory service for non-Muslims was only introduced formally in 1856 and practically in 1909 (Zürcher 1998; Hacısalihoğlu 2007).

12 Ghazan Khan, for example, forged alliances with the crusaders against the Mamluks, subdued religious upheavals caused by a Muslim Mongolian ally, who supported the persecution of Christians and Buddhists, and made the Jewish convert Rashīd al-Dīn al-Hamdhānī a vizier (executed by his successor in 1318). 
of European merchants was regulated by so-called Capitulations, bilateral agreements between the Ottoman Empire and its European counterparts; such agreements, through which European merchants fell under foreign jurisdiction and evaded local taxes, were signed with the republics of Genova, Venice, Florence, and Naples as early as the fourteenth century, and later also with France, England, and the Dutch Republic; they remained in place until the twentieth century (Schölch 1975). On the other hand, Christians, caught in enemy territories or on the peripheries of the empire, were enslaved and served in many sectors of Ottoman society. According to Zilfi $(2009,531)$, slaves and former slaves made up a fifth of Istanbul's population in the sixteenth century, when Istanbul was the largest city in Europe and West Asia. As slave-ownership was associated with high social status, non-Muslims were discouraged from holding slaves, yet Christian and Jewish slave owners could be found "well into the 19th century" (ibid.). Christian boys from lands under Ottoman rule were taken from their families through devşirme (the child levy system) until the early eighteenth century; they were taught the Ottoman language and culture, converted to Islam, and trained as Janissaries (yeni çeri, "new soldiers"), which were established in the 1380s and existed until 1826 (see Ágoston 2009). As the elite corps of the sultans, or kapıkulu ("slaves of the Porte"), they enjoyed many privileges, were paid for their service, and could acquire a prominent status in administration and society; since the seventeenth century, they were also allowed to engage in trade and craftsmanship. Muslims and Turks were initially excluded from devşirme to avoid the development of a hereditary military aristocracy - a practice which only changed in the seventeenth century (ibid.). Enslaved girls and women of Christian and Jewish faith and of different ethnic origins also formed a continuous part of the sultans' harem; many of them also gave birth to children. As sultan's mother (wālidat sulțān), they not only enjoyed authority inside the Imperial Harem, but also seized political power, especially in the sixteenth and seventeenth centuries (Peirce 1993). ${ }^{13}$ Non-Muslim European visitors found the porous boundaries between the free and the enslaved as well as the social mobility of slaves "most striking and foreign to the aristocratic governance of their own countries" (Zilfi 2009, 532). At the same time, Christian rulers from Europe could be Ottoman allies,

13 Famous examples for this are Khürrem Sulțān, known as Roxelana (d. 1558), and Kösem Mahpeyker Sulțān (d. 1651). Roxelana was captured by the Crimean Tatars in Ruthenia and sold to Istanbul, where she rose from a slave girl to the favourite concubine and wife of Suleiman the Magnificant (d. 1566). Kösem, of Greek origin and the daughter of an orthodox priest, was sold by the Bosnian governor to the harem of Sultan Ahmad I (d. 1617), whose wife she became. After his death, she seized power during three periods of time, acting on behalf of two of her sons and a grandson. Both Roxelana and Kösem met a violent death after their fall from power. 
vassals, or enemies, just as other Muslim rulers could be considered opponents, rivals, or allies (Gürkan 2010). ${ }^{14}$

In spite of the dhimma institution, there were recurrent cycles of pressure against and laxness regarding non-Muslims throughout the centuries. Under the Ottoman Sultan Mehmed IV (d. 1693), military conquest and religious conversion were directly linked with each other; his war strategy aimed not only at converting individual Christians and Jews, but also at Islamizing the landscape by turning churches and synagogues into mosques (Baer 2008). There were also several documented attempts to forcefully convert Jews to Islam, for example in Andalusia and the Maghreb under Almohad (al-Muwaḥhidūn) rule ${ }^{15}$ in the twelfth century, or in Persia under Safawid rule in the seventeenth century as well as under Qajar rule in the nineteenth century (Reinkowski 2013, 88-90). Although rulers and authorities were well aware that forced conversion fostered techniques of dissimulation, they seem to have turned a blind eye and accepted them, not to mention that Jewish rabbis recommended them. Mōshe $b$. Maimūn, better known as Maimonides (d. 1204), pleaded for outer conversion when faced with the choice between emigration or death and emigration was impossible (Boušek 2011). In his correspondence, especially in his Epistle to Yemen (1172) in support of the Yemeni Jews, who seem to have faced persecutions at that time, Maimonides bitterly complained that the harsh treatment by the Arabs was unprecedented even in Jewish history: "Never did a nation molest, degrade, debase, and hate us as much as they" (quoted ibid., 50). It is controversial whether Maimonides himself was forced, under Almohad pressure, to pronounce the shahāda (Islamic creed) before he left Andalusia for Egypt (ibid., 54-59), where he was appointed by the Ayyubids as the nagid (religious leader) of the Jewish community. Two Arabic sources even tell the story that he was accused of apostasy (ridda) by a jurist in Egypt who had known him as a Muslim in Andalusia; according to the sources, the charge was dismissed by the judge at the Ayyubid court on the basis that a forced conversion was invalid and could therefore not fulfil the criteria of apostasy (ibid., 58f.).

With regard to the Christians of European regions, Muslim perceptions since the seventh century followed neither a single pattern of superiority and hostility nor a

14 For example, in the Battle of Ankara (1402) against Timur's Mongols, Christian vassals from Serbia and Albania fought bravely and loyally on the Ottoman side, while Black Tatar and Turkmen troops changed sides and joined the Muslim Mongol leader's multi-ethnic forces. During the Battle of Vienna (1683), not only did the Ottoman troops include confederates from Wallachia, Upper Hungary, Moldavia, and Transylvania, but Crimean Tatars were also on the Ottoman side, while Lipka Tatars fought with the Polish relief forces.

15 For a nuanced picture of the Almohad rulers, who were formerly often depicted as fanatics, and their treatment of Jews, see volume 2 (2) of the Journal of Medieval Iberian Studies, especially the articles by Bennison/Gallego (2010), Bennison (2010), and Corcos (2010). 
terminological consensus about the names, titles, toponyms, and ethnonyms applied to a broad range of peoples of the northern hemisphere (König 2010; Bennison 2007, 165-173). While the Qur'ān already used an intricate terminology for Christians, further inconsistencies resulted from the complex practical relations with various Christian groups. In spite of numerous refutations of Christianity by Muslim theologians, a combined religious and geographical definition of "Latin Christianity" as an entity in its own right "does not seem to have existed" (König 2010, 32) until early modern times. Different sources classified the pope as "the damned one," the "caliph of the Franks," or the "friend of kings and sultans" (ibid., 39). This inconsistency attests to the fact "that Muslim scholars were not in agreement on how to classify an institution whose activities had never been confined to the European continent" (ibid., 42). Apart from this, the land-conquering Umayyad and 'Abbasid rulers viewed themselves as heirs of previous civilizations, including Greece, Rome, Byzantium, and Persia, and therefore had no qualms about incorporating their predecessors' knowledge and techniques into their own administration (e.g. Husayn 2012; Kaplony 2016). Some Ottoman sultans "aspired to and perhaps even believed themselves to be Roman Caesars, Kayser-i Rum" (Gürkan 2010, 15). The conqueror of Constantinople, Mehmed II (d. 1481), considered himself the "true heir to the Roman throne" and "did not hesitate to consider the propaganda that linked the Ottoman and the Komnenos dynasties" (ibid.). He understood himself as "the Islamic fulfiller" of Roman imperial power rather than its destroyer, "curious about and responsive to Italian and wider European culture" (Abulafia 2012, 291). ${ }^{16}$

As early as the eighth century CE, the Umayyads conquering Andalusia laid claim to Roman heritage; some of them even claimed descent from the Visigoths (Bennison 2007, 162). According to the sources, there seems to be evidence of "agreements and alliances between Muslim commanders and Visigothic notables" (ibid.) during the early conquest of Spain, which was accompanied by cases of intermarriage. The symbiosis between Visigothic and Umayyad styles was not only expressed in the adaption of local customs, but also in architecture and urban planning (ibid., 164f.). This kind of co-operation on several levels stands in contrast to the myth of the reconquista, which began to emerge as early as the ninth century at the Asturian court (ibid., 161). With regard to Christian slaves and captives from the North, a common ethnic term for men was saqlabì ("Slav"), while women were often called rūmiyya ("Christian") in Andalusia. In reality, both men and women could hail from anywhere between the domains of the Carolingians and the Volga, since there existed various commercial routes with

16 His claim was rivalled by opponents like Alfonso the Magnanimous of Aragon (d. 1458), who tried to defend the Balkans, the Adriatic, and the eastern Mediterranean against the Turks; a romanized Spaniard, Alfonso saw himself as "the spiritual and in a sense the physical heir to Trajan and Hadrian, Roman emperors of Spanish origin" (Gürkan 2010, 15). 
merchants of diverse religious and ethnic background involved (ibid., 172). The majority of captured women seems to have come from northern Iberia and entered elite households as wives, concubines, and domestic servants, and continued on speaking their native languages. Because of this, the Muslim elite even feared that romance was ousting Arabic in the families, since "the majority of the mothers of amirs and caliphs were of northern origin" (ibid., 173); paradoxically, Christians in Andalusia were, at the same time, concerned that the spread of Arabic as a literary, scientific, and public language would replace Latin.

A peculiar case of entanglement between Muslims and the local population is the Arab, or possibly Berber, outpost called "Fraxinetum" in Latin sources (arab. Farakhshanīț) that existed between the end of the ninth and the end of tenth centuries in the Provence near today's St. Tropez (Versteegh 1990; Vogel 2016), independent or semi-independent from Cordoba. ${ }^{17}$ The sources attest that after their defeat, not all of the "Saracens" were killed, but some of them stayed in the region and converted (Versteegh 1990; Vogel 2016). Fraxinetum represents an early example of a landscape in which a multiplicity of actors with different identities, loyalties, and interests interacted. Like Fraxinetum, Andalusia as well as the Umayyad, 'Abbāsid, and Fatimid empires in the Eastern Mediterranean were connected with northern Europe via trade routes through which slaves (șaqāliba) from Middle and Eastern Europe were traded for dirhams up to the eleventh century (e.g. Jankowiak 2017). The import of goods and spices from the centers of Muslim commerce profoundly changed the emerging European economy-a transformation that was not only visible in the goods that travelled, but also in the movements of pilgrims, warriors, slaves, merchants, diplomats, and emissaries (McCormick 2001). This trans-cultural mobility across the Mediterranean found its continuation in early modern times, when European states had Muslim subjects, renegades, and allies, just as the Ottoman and North African states had Christian and European ones (see e.g. Davis 2006; Konrad 2010; Krstić 2011; Graf 2017).

For the global circuit of knowledge production about Islam, it is therefore necessary to have a look at such inter-connections between the various Muslim and non-Muslim contexts. Before I turn to this subject, let us first of all consider how three examples that seem to contradict the multi-religious topology of Islam fit into these considerations.

17 From here, the Berbers controlled trade routes and alpine passes and raided the region between today's Italy and Switzerland, but also participated in the trans-regional slave trade-actions that were similar to those practiced by other non-Muslim local and regional powers, with which the Berbers rivalled. Although the sources written by clerics paint a rather negative image of the "Saracens," the religious difference may have only represented one factor among others and prevented neither co-operation between Muslims and their non-Muslim peers nor intermarriage (König 2017). 
Following this, I will then examine how Muslims and non-Muslims understood and debated the position of Jews and Șūfīs-as "inside outsiders"-under Muslim rule. In a further step, I describe how the trope of Islam as an anti-Trinitarian Christian heresy circulated throughout history and was connected with debates about religious violence and tolerance. Then, I shed light on the European knowledge production on Arabic philosophy and Islam by way of translation work.

\section{Three Examples of Seemingly Non-Diverse Spaces}

A famous tradition expressing and denigrating religious diversity at the same time is Muhammad's hadith about the sects (firaq) that stipulates, in different versions, that Islam will be divided into 73 sects in contrast to the 71 Jewish and 72 Christian groups, and that only one, the 73rd group, will be saved from hellfire (for background information, see van Ess 2011, 3-64). Plurality inside Islam and religious diversity-as also noted in Qur'ān 5:4818-are therefore a given in Islamic tradition. Yet they do not directly express tolerance, since the claim to one religious truth is not dropped but postponed and subjected to a practical test. In this context, it is necessary to underline, as van Ess $(2011,1298)$ has done with reference to Islamic heresiography, that the terminology of "orthodoxy" and "heterodoxy" has no clear-cut analogy in Islam due to a lacking central authority for questions of faith. This does not mean that there were no processes of denouncing, centralization, and confessionalization or attempts to define dogmas; on the contrary, there were ongoing struggles for the dominant position ${ }^{19}$ which often, but not in every case, rested on the trials and tribulations of political luck and servitude. ${ }^{20}$ In the face of the difficulty to ascertain which Islamic group was the saved one, the Șūfi Yunus Emre (d. 1321) voiced the idea that "you should kiss the feet of the 72 sects" (van Ess 2011, 3). His praise for plurality implicitly results from the

18 "We have sent down to you the Book with the truth, confirming what was before it of the Book and as a guardian over it. (...) For each [community] among you We had appointed a code [of law] and a path, and had Allah wished He would have made you one community [nation], but [His purposes required] that He should test you in respect to what He has given you. So take the lead in all good works. To Allah shall be the return of you all, whereat He will inform you concerning that about which you used to differ."

19 Langer and Simon $(2008,281)$ argue that a claim to orthodoxy "must meet certain requirements, such as body of texts, a genealogy, flexibility, comprehensibility, the ability to integrate deviation, to manage boundaries, and produce consent."

20 A famous example to define orthodoxy is the so-called mihna ("ordeal") period (833-848 CE), when the caliph proclaimed the Mu'tazilite doctrine of "the createdness of the Qur'an" (see e.g. Nawas 1994). 
failure to draw a clear line that would separate the 73th group from all the others. The attempt and failure to draw a separating line thus marks a spatial practice that divides and connects different groups at the same time.

Historically, the way of negotiating this separating line could turn fatal, accept ambiguity, or lead to a schism. In rare circumstances, the interaction between Sunni authorities and the rulers' quest for legitimacy could lead to the execution of respected scholars, as was, for example, the case with the Persian Șūfĩ scholar Shihāb al-Dīn alSuhrawardī (d. ca. 1191/92) and the Arab Shī'î scholar Zayn al-Dīn al-'Āmilī (d. 1558). Although the reports at hand about the events that culminated in these executions appear confusing and contradictory, it seems obvious that the scholars were put to death under the charge of holding unorthodox or heretical views (zandaqa) (Marcotte 2001; Stewart 2008). Suhrawardī, who was killed under Ayyubid rule in Aleppo, had created the philosophy of illuminationism (ishrāq), drawing on Zoroastrian symbolism; he had made himself enemies among the local religious authorities (Marcotte 2001). The execution of Zayn al-Dīn al-'Āmilī by the Ottomans in Istanbul (Stewart 2008) may have happened against the background of the wider Ottoman-Safavid conflict.

It has recently been argued that a series of uprisings by the Turkish Shiites called "Kızılbaş" ${ }^{21}$ triggered an "Ottoman Sunnitization" (Terzioğlu 2013) in the sixteenth century, "the development of legalistic Sunnism as Ottoman state doctrine" (Dressler 2005, 131) as a double demarcation against the Kızılbaş "heresy" and the Safavid empire. The case of the Kızılbaş/Alevis is a striking example of the paradox and dynamic character of in- and exclusion. In the nineteenth-century Ottoman Empire, the Kızılbaş renamed themselves Alevis by adopting-with the help of Protestant missionaries (Kieser 2001) - the classification of being "heterodox" or "synchretistic" Muslims from Western scholarship as a new self-description. This formula was subsequently not only applied by the new Turkish state and its intellectuals to write Alevis (as TurkishKurdish Muslims) into the secular nation state and to simultaneously marginalize them (as heterodox), but it has also offered the Alevis the opportunity to develop a new standardised and dogmatic form of Alevism in recent decades (Kreyenbroek 2005; Langer and Simon 2008, 285-287; Dressler 2013). Other religious minorities, formerly classified by Muslim heresiographers as "heretics" or "extremist Shī'îs" (ghulāt) and by Western scholars as "heterodoxies," have also started to transform their oralbased traditions and practices in similar ways into more standardised modern canons (Kreyenbroek 2005). A peculiar case in point is Yezidism, which can historically be regarded as an offshoot of a Șūfī movement in the twelfth century, though it soon developed into a religion in its own right, especially in the eyes of modern Yezidis

21 The name "Redhead" refers to their red headgear worn by followers of the Safawid Shah. 
(Kreyenbroek 1995; Langer 2010). The dispersal of Yezidis across several nation states in the twentieth century created the need to define Yezidism for different state administrations in order to gain recognition, thus resulting in a kind of a "transnational orthodoxy" (Langer 2010). In other words, what others had called an Islamic heterodoxy finally ended up creating its own non-Muslim orthodoxy, and thus a case of internal Muslim diversity transformed into external diversity.

The second example of non-diversity is the Muslim attempt to mark a space that is explicitly not multi-religious, the haram districts in the Hijāz, which non-Muslims are forbidden to enter and to reside in. ${ }^{22}$ The ruling is derived from a saying by Muhammad and from accounts of early Muslim scholars that in the time of the second caliph 'Umar b. al-Khațțāb (d. 644), the Hijāz, or the whole Arabian Peninsula, was freed from the presence of non-Muslims through expulsion (Munt 2015, 250). On the one hand, the ruling has been debated by Muslim scholars for several centuries, and the existence of Jewish and Christian communities within the Hijāz and the Arab Peninsula has been reported by various Muslim sources for several centuries (Munt 2015, 251, 259-261). On the other hand, this kind of marking an exclusively Islamic space, in turn, leaves the overwhelming swaths of dār al-islām unmarked, thus implicitly affirming its multireligious nature. Throughout the history of Islam, the common visit of sacred sites by different believers is attested all over Africa, Europe, and Asia (e.g. Hasluck 1929; Fowden 1999; Hayden 2002; Cuffel 2003; Cuffel 2005; Bowman 2012; Couroucli 2012). As Doris Weltecke $(2012,73)$ has argued, such multi-religious sites "were considered neither entirely bizarre nor exactly quotidian". Discussing several examples of "powerful Christian saints" that were also venerated by Muslims, she differentiates between different social and political practices at these sites according to the circumstances. Thus, forms of "spatial," "non-egalitarian," and sometimes "egalitarian" convergence at multi-religious sites can be differentiated according to the object of veneration, the participants involved as well as their motifs, and the dynamic relationship of power and legitimacy. The different spatial arrangements also reflect different uses; historically, sites of multi-religious contact and exchange were used to stage universalism and unity, express power and legitimacy, or mediate in religious disputes and contradictory claims (Beinhauer-Köhler 2015).

The third example revolves around the long-standing relations between Buddhism and Islam (e.g. Elverskog 2010; Yusuf 2010 and idem. 2013; Truschke 2018) and questions the formerly widespread consensus that Buddhism went extinct in India because of "the power of the Islamic sword" (Truschke 2018). A special place in this narrative has been reserved for a Mamluks' raid of Nalanda, the biggest Buddhist monastery

22 For the emergence of the haram districts, see my article "Where Do the Multi-Religious Origins of Islam Lie? A Topological Approach to a Wicked Problem" in this volume. 
in eastern India, because it is said to have signalled the death of Indian Buddhism in 1202. As Elverskog (2010) argues, the Buddhist rulers arranged themselves with their Muslim overlords, and teaching at Nalanda carried on for more than another century; the dharma remained in India until the seventeenth century: "In other words, Buddhists and Muslims lived together on the Asian subcontinent for almost a thousand years" (ibid., 2). The pertinence of the narrative about Muslim barbarism is partly explained by the fact that the British used it to justify the imposition of their own colonial rule in the face of Moghul rule in India and that it feeds into the stereotypes of peaceful Buddhism versus violent Islam. However, spaces such as the Silk Road or Mongol Iran provided opportunities where Muslim scholars and Buddhist monks engaged with each other in theological discussions and new ways of thinking (Elverskog 2010). Vaziri (2015) has recently analysed the Buddhist impact on the famous Persian mystic Jalāl alDīn al-Rūmī (d. 1273). According to Vaziri, al-Rūmī rebelled against the scholastic and hierarchical Islamic establishment with his philosophy of non-dualism, especially in his Dìwān-e kabìr, where he treated central philosophical and anthropological concepts that show clear parallels to advaita Vedanta and Buddhism. Classical Orientalist scholarship already paid some attention to parallels between Buddhism, on the one hand, and Islam and especially Sufism, on the other (Goldziher 1903; Nicholson 1914, 16-27). Vaziri's interpretation, however, calls into question the very notion of two distinct "religious" traditions and presents al-Rūmī as an transcultural and Universalist philosopher. Here, the question arises whether a religious category for al-Rūmī would be adequate at all. Yet locating his ideas in a multi-religious landscape in which different ideas about the meaning of life are negotiated still makes perfect sense.

\section{The Perception of Jews and Șūfīs as Inside Outsiders of Islam}

The term "Islam" is not only characterized by the inclusion of Biblical material (in the Qur'ān), but also by the presence of Jews and Christians (under Muslim rule). Therefore, it is possible to state that the boundaries of Islam include Jews and Christians to a certain degree, especially if one thinks, as does Shahab Ahmed (2016), for example, that the term "Islam" encompasses religious ("Islamic") as well cultural ("Islamicate") meanings. Ahmed (2016, 174f.) believes that an Arabic-speaking Jewish philosopher like Maimonides not only belongs to the context of Islam, but that he is, in effect, an "Islamic Jewish thinker", though not a Muslim one. Although this differentiation is not 
convincing for Ahmed's critics (e.g. Griffel 2017, 14)23, it seems adequate to me to see Jews, Christians, and unconventional believers like Șūfīs as "inside outsiders" of Muslim societies; they not only exchanged ideas among each other, ${ }^{24}$ but their mere existence challenged the spatial practice of clearly distinguishing between inclusion and exclusion. In so far as their belonging to Muslim societies posed a challenge for religious and political authorities, they were subject to different forms of arrangement and treatment throughout history and attracted the attention of observers beyond the borders of Muslim empires. The positions of Jews and Șūfis under Muslim rule form a central point of reference for Muslim as well as non-Muslim perceptions of Islam.

The presence of Jews in early Islamic sources-alongside Christians-has been interpreted as the expression of a special relationship between the Abrahamic religions, yet sometimes also as a danger for the purity of Islam. According to early Arabic sources, Yemeni Jewish converts, such as Ka'b al-Aḥbār (d. 652) and 'Abdallāh b. Salām (d. 663), were among the main informants who contributed to the emergent genre of isrā'illiyyāt, a body of narratives of Biblical background that include legends about former prophets (qișaș al-anbiyā') which did not directly appear in the Qur'ān and Islamic literature (Vajda 1978). This material gained much currency in historiography and tafsïr works because it helped to explain Qur'ānic verses as well as material from the Hadīth literature. While scholars in early modern times were divided about the usefulness of these additional Biblical narratives and the Jewish converts' trustworthiness, the genre of isrā'illiyyāt has been severely criticized in modern times, especially in the twentieth century (Lang 2015). The figure of the "arch-heretic" 'Abdallāh b. Saba', whose conversion is mentioned by pro- and anti-Shī'i authors since the end of the eighth century (Anthony 2011, 1f.), plays an important role in religious polemics, as he is said to have propagated an array of insidious doctrines after hisprobably feigned-conversion. While liberal authors in the twentieth century, such as Ṭāhā Husayn (d. 1973), contested the historicity of the reports about Ibn Saba', this figure was used to discredit the Shī'a because of Ibn Saba"s alleged relations to early "Shī'ī" protagonists and also served as an early example of a Jewish conspiracy against Islam (Ende 1977, 199-210). Another example for such a conspiracy theory concerns the Dönme from Salonika - a movement going back to Shabbatai Tzevi (d. 1676), who proclaimed himself the messiah but later (under pressure?) converted to Islam with his adherents; according to the proponents of the conspiracy theory, the Dönme controlled the Young Turk movement of 1908 and still controls the Turkish Republic and even Turkish Islamists (Baer 2004; 2007; 2010).

23 Griffel $(2017,14)$ remarks that "one should not expect any cultural product not to be Islamic given that it all belongs to the context."

24 For the reciprocal exchange between Jews and Șūfīs especially in Mamluk Egypt see Fenton (2017). 
In spite of such negative judgements of Jewish influences on Islam, European Jewish scholars in the nineteenth and the twentieth centuries played a key role in the development of a nonpolemical evaluation of Islam in European academia, thus acknowledging and sometimes romanticizing the merits and achievements of "Muslim civilization" (Kramer 1999). This "Jewish discovery of Islam" (ibid.) can be traced back to Abraham Geiger's (d. 1874) Was hat Mohammed aus dem Judenthume aufgenommen? (1833), which was followed, among others, by Ignaz Goldziher's (d. 1921) studies. In these works, Islam and Judaism appeared as kindred faiths-an approach that strongly influenced the emergence of modern Islamic studies in Europe and the USA and undermined the idea that East and West were polar opposites. As "mediators between Europe and Islam" (Kramer 1999, 5), Mediterranean Jews, in particular, posed a challenge to the dichotomies on which modern Europe was constructed in the nineteenth and early twentieth centuries: Christendom versus Islam, Europe versus Asia, Aryan versus Semite. Jewish scholars' views rested on the argument that Jews had helped to bring the civilization of medieval Islam to its apex and could do the same for the civilization of modern Europe; hence the active association of European Jews with Islam in the nineteenth century, which was even reflected in the construction of urban synagogue architecture in "Moorish" style.

In recent decades, a renewed interest in the Jewish history on the Arabian Peninsula has tried to ascertain what kind of Jews lived in and around Medina in pre-Islamic and early Islamic times (Lecker 1985; 1995a; 1995b; 2012; 2016; 2017). For the pre-Islamic presence of Jews, there are, however, only indirect clues through scattered inscriptions, which point more or less conclusively at Jewish names and expressions (Hoyland 2011)-apart from accounts about the Himyarites of Yemen who adopted Judaism in the sixth century.

The Muslim and non-Muslim interest in the mystics of Islam follows a somewhat different trajectory. Șūfīs are known for their eccentric practices, appearances, and views. Al-Ḥusayn b. Manșūr Ḥallāj, who was crucified in Baghdad in 922, had not only built "a model of the Ka'ba at his home for private worship" (Mojaddedi 2013) and advocated the building of further replicas for those unable to travel to Mecca; he also uttered "I am the Truth" (anā I-haqq) - "the most notorious of all theopathic utterances (šațahāt) recorded in the history of Sufism" (ibid.). Other mystics prayed by hanging upside down (čella-ye ma'kūsa/namāz ma'kūs); by so doing, Abū Sa'īd Abī l-Khayr (d. 1049) claimed that his body had become the qibla (direction of prayer) (Vaziri 2015, 184). The Șūfi insight that "the striving for God through exercises of self-denial leads to self-centered religious practice" (Böwering 1983) also made the Șūfīs level harsh criticism at outward religiosity, expressed in the verses attributed to Abī I-Khayr: "Not until every mosque beneath the Sun/Lies ruined will our holy work be done;/And never 
will true Muslim appear/Till faith and infidelity are one" (Vaziri 2015, 185; Nicholson 1914, 90).

Irrespective of the condemnation of some Șūfĩ practices and views by scholars like Ibn Taymiyya (d. 1328), Imam Birgivī (d. 1579), Muhammad b. 'Abd al-Wahhāb (d. 1792), or by reformers of the nineteenth and twentieth centuries, Șūfīs were mostly regarded as part of the Islamic mainstream and often enjoyed popular support as well as the rulers' patronage, especially in the Mughal, Safawid, Ottoman, and Sokoto empires; they were a cause for perplexity rather for scholars of religion than for Muslims themselves (see O'Fahey and Radtke 1993; Radtke 1994; van Ess 1999), especially since the supposedly spiritual leaders of Șūfĩ brotherhoods often led the anti-colonial resistance against European powers in the nineteenth century.

Some scholars of religion even tried to racially divide Islam into an Aryan-Șūfī and an Semitic-Sunnī branch, arguing that Sufism showed signs of Aryan creativity since it was too intellectually demanding to have been blossomed from the heart of true Islam (Masuzawa 2005, 197-204). In a similar vein, Ibn 'Arabī (d. 1240), defamed by some Sunnī scholars because of the possibly pantheistic concept of wahdat al-wujūd ("unity of existence") ascribed to him, rose to recognition among the critics of conservative and salafĩ scholarship. The European converts to Islam Ivan Aguéli (d. 1917), René Guénon (d. 1951), and Frithjof Schuon (d. 1998) turned Ibn 'Arabī into their principal witness for perennialist universalism, within which also lurked the spectre of Aryanism (Lipton 2018; 2017). Although Ibn 'Arabī welcomed diverse interpretations of Qur'ānic verses, it is possible to argue that he subscribed neither to pluralism nor to relativism in religion-in spite of some famous verses that give this impression. ${ }^{25}$

In his dissertation of four volumes on al-Hallāj (1922), the French Orientalist Louis Massignon (d. 1962) followed a different approach to Sufism by drawing parallels between the passion of the "martyr mystique de I'Islam" (Massignon 1975) and Jesus Christ. Massignon, who had converted from agnosticism to Catholicism in Iraq and Lebanon around 1907, strove to understand Islam from the inside but criticized the Islamic negation of incarnation; he later joined the Melkite Greek Catholic Church, whose liturgical language is Arabic, because he thought that this would bring him as close to Islam as one could possibly get as a Catholic.

At the beginning of the twenty-first century, after several attacks on Șūîs by radical groups, a politicized division between Sufism and orthodox Islam has re-

25 See, for example, the often quoted Poem XI from the Tarjūmān al-Ashwāq: “My heart has become capable of every form: it is a pasture for gazelles and a convent for Christian monks, / And a temple for idols and the pilgrim's Ka'ba, and the tables of the Torah and the book of the Koran. / I follow the religion of Love: whatever way Love's camels take, that is my religion and my faith" (Ibn 'Arabī 1911, poem XI, lines 13-15). 
surfaced in popular media to give credit to the conceptualization that "Islam is understood as inherently intolerant and incompatible with Western secularism, while Sufism (commonly referred to as Islamic mysticism) is claimed to be profoundly tolerant and secular because similar to Christianity" (Lipton 2011, 427). Thus, as Lipton (2011, 427f.) notices, "Sufism functions in current US political discourse as a template for an 'alternative' Muslim subjectivity (...) more readily in tune with the ethos of American individualism, liberalism, and neoliberal privatization."

\section{The Global Circulation of Ideas about Islam}

The trope of Islam's anti-Trinitarianism circulated in different ways across time and regularly reappeared at turning points in history. Thus, it left its imprint on European debates about the nature of Turks and Native Americans, the confessional quarrels following the Reformation, and debates about religious tolerance and slavery during the Enlightenment. Anti-Trinitarianism is among the "stereotypes that have dominated Western Christian discourse about Muslims since the reception of John of Damascus' depiction of Islam as a heresy" (Ralston 2017, 756). While it basically marked Islam as a Christian heresy, it later also turned into a positive ascription. The idea that Muhammad "had revived an early, truer form of Christianity, in which the Trinity and Jesus's divinity were later corruptions" (Spellberg 2013, 68) was already circulating underground in mid-seventeenth-century England; it was articulated in an unpublished treatise by John Locke's fellow student of Arabic, Henry Stubbe (d. 1676), who fostered "Unitarian"26 ideas about God (Garcia 2012, 1-59). A group of Muslims in London finally succeeded in publishing Stubbe's treatise in 1911 (ibid., 225-231). Thus, the scholar of Qur'ānic studies Günter Lüling's (1993) approach, arguing that Islam represents an early and pure form of Christianity, is not without precedent. ${ }^{27}$

With the fall of Constantinople (1453 CE), the anti-Trinitarian nature of Islam was, for example, perceived differently, respectively, by Nicolaus Cusanus (d. 1464) and Enea Silivio Piccolomini (d. 1464), the later Pope Pius II. While Piccolomini held that the antiTrinitarian stance of Islam was a heresy that should be fought militarily, Cusanus tried to convince him that Islam and Christianity were closely related and dialogue should be the first option (Poppe 2014). In De pace fidei ("On the Peace of Faith," 1453), written under the impression of the fall of Constantinople, Cusanus argued against the crusade idea; in Cribratio Alkorani ("Sifting the Koran", 1460/61), he maintained that all Christian

26 This first use of the term in English print dates from 1672 (Spellberg 2013, 322).

27 For more on Lüling's approach, see my article "Where Do the Multi-Religious Origins of Islam Lie? A Topological Approach to a Wicked Problem" in this volume. 
doctrines were, at least in nuce, to be found in the Qur'ān, even the idea of the Trinity, which Islam openly renounced (Rudolph 1994, 101 and 105). To explain this closeness, Cusanus, drawing on the Bahīrā legend ${ }^{28}$, stated that Muhammad had been educated by a Nestorian monk named Sergius as a Nestorian Christian, but was later diverted from the true faith by three sly Jews (ibid., 103). In several places, Cusanus's attempt to co-opt Islam rested on a misreading or misinterpretation of the Latin translation of the Qur'ān (ibid., 105-107).

The same trope also played a role in the famous dispute between Bartolomé de las Casas (d. 1566) and Juan Ginés Sepúlveda (d. 1573) over the rights of indigenous peoples in newly discovered America, in which the imago Turci lay at the core of the dissent. "Where Las Cases tried to prove that the Indians were not 'Turks' and should be treated differently, that is peacefully, Sepúlveda extended the European attitude towards the Turks to the treatment of the Indians" (Mastnak 1994, 127). The underlying rationale in this dispute was an internal dialogue of Europeans with themselves and with Thomism, first, to determine what Christians were allowed to do to infidels and pagans and still feel just and virtuous and, second, to refute the Lutheran theory of dominium and sovereignty, which was based on God's (volatile) grace, not on a Papal bull (ibid., 130; Pagden 1987). In this respect, the disputants and the conquistadores shared the view that the conquista in Latin America was the continuation of the reconquista in Spain (Mastnak 1994, 139), and that crusading had not come to an end but was still justified. Where Sepúlveda used his arguments for war against the Turks to also justify war against the Indians, Las Cases constructed a difference between Muslims and Native Americans; in other words, his love for Indians fed on his hatred for Turks, Moors, and Saracens. Las Casas could only "argue for peaceful treatment of the Indians because he accepted the justice of war against Muslims" (ibid., 144), charging Sepúlveda "with the desire to spread the faith with 'Mohammedan method', that is, "with death and terror" (ibid.). References to the Turks were "an organizing principle" (ibid., 140) in both the disputants' reasoning. Mastnak (ibid., 131) therefore thinks that "once we see how much the image of the 'Turk' determined the sixteenthcentury debate over the Indians, it becomes clearer how much our own story of the discovery of the New World, overlooking as it does that central, fictious, figure of the Turk, continues to be wrapped in fictions."

Since the early times of the Reformation, Catholics as well as Protestants used the figure of the Turk to discredit one another's dogma and construct a close relationship of their opponents to Islam. Most Protestants in Europe and America described and

28 According to Muslim biographers of Muḥammad, the monk foretold Muhammad's prophethood when he met him as a young man; in the Christian tradition, the heretical monk's ideas are said to have inspired the Qur'ān. 
depicted the Antichrist "as a beast with two heads-one a mitered pope and the other a turbaned Ottoman Sultan" (Spellberg 2013, 15; Kidd 2003; Ralston 2017). Yet while religiously legitimatized violence raged in the sixteenth and seventeenth centuries, a minority of Catholics and Protestants spoke out against violence and defended Muslims and Jews from coerced conversion, state persecution, and violence. Although their "ideas were never considered acceptable while they lived" (Spellberg 2013, 40), these ideas evolved over the centuries and were eventually espoused by the Founding Fathers of the USA, as Spellberg (2013) has shown.

Thus, a twisted line of thought and argumentation, drawing on images of Islam ${ }^{29}$, connects Michael Servetus (d. 1553) and Sebastian Castellio (d. 1563) to John Locke (d. 1704) and Thomas Jefferson (d. 1826). The immolation of Spanish theologian and humanist Michael Servetus at the gates of Geneva in 1553 found widespread approval in Europe because both Protestants and Catholics condemned his ideas. Inspired by Erasmus's (d. 1536) annotations to the New Testament-especially by Erasmus's view that the "Johannine Comma" was a later interpolation to the Latin Vulgate, not contained in early Greek texts ${ }^{30}$-, Servetus concluded that the doctrine of the Trinity had no basis in the Bible (Bietenholz 2009, 33-37; McDonald 2017, 70f.). Fleeing from the inquisition in France to Geneva, Servetus asked John Calvin (d. 1564) why Jews had been expelled from Spain in 1492 and Muslims persecuted for refusing "a concept not found in Christian scripture, and whose abstruse nature remained a barrier to the ultimate Christian aim of the conversion of both Jews and Muslims" (Spellberg 2013 , 48). A year after the public immolation of Servetus for heresy, Castellio, under a pseudonym, composed a treatise in which he deemed the persecution of heretics unchristian, arguing that "to kill a man is not to defend a doctrine. It is simply to kill

29 As mentioned above, the terminology in early modern Europe with regard to Muslims was not stable and did not refer to a faith called "Islam" in French and English before the late seventeenth and early nineteenth century, respectively. Here and in the following examples, "Islam" is therefore not the term used in most primary sources but the analytical tool with which I access the unifying talk about the Muslim (Turk, Saracen, etc.). Other in order to lay bare the multi-perspectivity connected with this talk.

30 The "Johannine Comma" in the First Epistle of John (5: 7-8), which was seen as a confirmation of the doctrine of the Trinity, seems to have originated as a gloss of the Vulgate in the fourth century (Houghton 2016, 178). Erasmus excluded it in the Greek text and in his Latin translation of the first printed New Testament of 1516 and 1519, and assumed that it was introduced in the course of debates with the anti-Trinitarian Arians. Martin Luther, who based his German Bible translation on Erasmus's work, also excluded the Johannine Comma. In order to avoid excommunication, Erasmus re-introduced the Comma in the third edition of 1522; from this edition, it became part of the King James Bible (1611). The Comma was also introduced into the Luther Bible from the seventeenth to nineteenth centuries. The Nova Vulgata (1979) no longer contains the phrase. I thank Markus Müller for drawing my attention to Erasmus's work. 
a man" (quoted ibid., 49). Convinced of Christianity's superiority, he did not believe that Muslims, as anti-Trinitarians, were equal as believers, but that religious strife "did nothing to further the salvation of non-Christians" (ibid.).

Thomas Helwys (d. 1616), who later founded the first Baptist church in England, published similar ideas when in exile in Amsterdam; he died in Newgate Prison in London because of his conviction that state and church should be separated (ibid., 53-55). The inclusion of Muslims in the defense of religious freedom was also argued for by Roger Williams (d. 1683), who opposed the Puritan theocracy in Massachusetts that persecuted, jailed, and killed Christian dissenters-Baptists, Quakers, Anglicans, and Catholics-as well as non-Christians. After business contacts with the Ottoman Empire and North African states intensified under the rule of Elizabeth I in 1580, and after Oxford University established a chair in Arabic in 1636, knowledge about Islam grew and became central to tolerationist debates in late seventeenth-century England because of the alleged similarities between Islam and the anti-Trinitarianism of Deists and Socinians. When Jews were allowed to return to England in 1656 for the first time since the Edict of Expulsion (1290), Muslim diplomats and traders also seem to have practiced their faith privately without government interference (ibid., 71). Whereas Locke had formerly rejected toleration for Christian dissenters, while including Jews and Muslims, he reversed his views and included them in the Latin version of his A Letter Concerning Toleration (1689), the English translation of which, however, omitted the anti-Trinitarian Christian Socinians (ibid., 75).

In America, Thomas Jefferson-an anticlerical Christian strongly influenced by Deist authors-took Locke's argument for religious freedom one step further when he pleaded against an established state church, thus following the petition of Protestant dissenters. Jefferson was not only an admirer of Locke, but also bought George Sale's first English translation of the Qur'ān from 1734 and immersed himself in the studies of the history of Islam, positively noting the Ottoman toleration of Christians (ibid., 68). While Locke's argument supports the toleration of Jews and Muslims under an Anglican government, Locke did not expect their salvation, save they converted. Jefferson, however, believed that "it was not for the state but the individual to be concerned about his own salvation" (ibid., 108). While his opponents pressed him on whether he really wanted to have a Muslim as future president (Spellberg 2006), Jefferson followed his own line of argumentation. On the one hand, in his speeches in the Virginia House of Delegates against state religion he compared the Anglican Church to Islam for his purpose to end the Anglican establishment in Virginia, thus using the long-standing Protestant polemical approach to denigrate both Catholicism and Islam. On the other hand, Jefferson left behind a Christian frame of reasoning regarding tolerance, thus using the case of Muslims and Jews in order to extend toleration to all faiths, including 
atheism (Spellberg 2013, 107, 111-123). Until the end of his life, Jefferson was proud of the Virginia Statue of Religious Freedom, drafted by him in 1777 and ratified in 1786, and believed that it had put into practice his universal visions of the equality of men. The "paradox of liberty" is, however, that Jefferson extended religious liberty to Catholics, Jews, and even Muslims, while he excluded black African and mixed-race slaves from his considerations. Muslim slaves probably outnumbered the 2,000 Jews and 25,000 Catholics at the inception of the United States, although it is impossible to ascertain the exact percentage of Muslims among the slaves who arrived in Virgina since 1619 and numbered more than 120,000 in the mid-eighteenth century (ibid., 121). ${ }^{31}$ While two or possibly four Muslim names among the 300 slaves owned by George Washington have been identified, the same has not yet been possible with regard to Jefferson's more than 600 slaves (ibid., 122). It is rather telling that in recent years, a consensus about Jefferson's personal life emerged among historians, saying that he fathered several children with his slave Sarah (Sally) Hemings (d. 1835) and had an African-American family, a fact rumoured about but kept secret for almost 200 years (Gordon-Reed 2008).

In this context, it is worth mentioning that the "first collective Christian statement against slavery" (Meggitt 2013, 76) in the British colonies, the 1688 Germantown Declaration by Quakers in Pennsylvania, is based on experiences and arguments that connect the Transatlantic slave trade with its Mediterranean counterpart. As the Quakers had to endure persecution and imprisonment and sometimes even fell victim to executions in England and the colonies, especially in the period between the Quaker Act (1662) and the Act of Toleration (1689), Quaker captives in Morocco and Algiers, paradoxically, "were freer to practise their religion as slaves in Barbary states than they were in England" (ibid., 53), although they suffered mistreatment here as there. This experience gave George Fox (d. 1691), the founder of the "Religious Society of Friends," in the late 1640s, "a concrete example with which to shame Christian authorities who prevented Quakers from meeting" (ibid., 55). The Quakers' zeal to spread their message throughout the world resulted in a number of encounters with Muslims and, in spite of the danger of enslavement, a benevolent attitude towards them. In 1658, the itinerant preacher Mary Fisher (d. 1698), one of the so-called "Valiant Sixty," was able to meet Sultan Mehmet IV in Adrianople, who listened respectfully to her and offered a military escort for her safe return to Istanbul, which she declined. The episode stands in contrast to Mary Fisher's experiences in Cambridge, England in 1653, where she was

31 The speculations range between ten to thirty percent (Considine 2018, 1). The early history of free and enslaved Muslims in the Americas is beyond the scope of this contribution. For a short overview of the Muslim presence since the sixteenth century see Curtis 2009; for the discursive use of Islam before US Independence see Kidd 2003. 
stripped to the waist and flogged, and in Boston, Massachusetts in 1656, where she was detained on arrival, forced to undress in public, jailed, and forcefully expelled, while her books and pamphlets were burnt (ibid., 60-62). Although the Quakers' experience with Islam, ranging between enslavement and tolerance, was two-sided, they dissociated the immorality of Muslims' acts from the morality of their religion, which was rather uncommon in the seventeenth century (ibid., 67). The four Quakers, who composed and signed the Germantown Declaration against African-American slavery, began their text with "a plea for empathy and remind (...) the reader of their fear of being captured at sea by 'Turks' and sold into slavery" (ibid., 76). By so doing, they did not draw on an anti-Turkish trope but opposed slavery from a universalist perspective by placing their co-religionists' experience with enslavement on a par with the slavery experienced by Africans in the British colonies. Thus, the declaration is a document of cultural intersections, showing that there is a "clear link between the origins of the movement to abolish slave trade in Africans and the Quaker's experience of Barbary slavery" (Meggitt 2013, 75f.). ${ }^{32}$

\section{European Knowledge Production about Arabic Philosophy and the Qur'ān}

As these examples show, ideas about Islam held and still hold a central place in European-American intellectual history. Even if these ideas about Islam did not directly deal with Muslims, they formed useful bargaining tools that helped to negotiate the treatment of Turks, Native Americans, Protestant dissenters, Catholics, Jews, and slaves. While knowledge production about Islam played an important role in this regard, the different uses of translations of Arabic texts and the Qur'ān by European writers, scholars, and theologians are too numerous to fit into one category, since they ranged from outright hostility or polemics to a humanist engagement with the text itself (Elmarsafy 2009).

The first translations from Arabic to Latin date back to the late tenth century and concern the use of the Astrolabe (Hasse 2013, 378). From the late eleventh to the thirteenth century, the translation of a vast amount of different texts, among them mathematical, astronomical, philosophical, and medical texts, took place in several waves in Italy and Spain and had a strong impact all over Christian Europe. Although there seems to have been a halt of the translation movement between 1300 and 1480,

32 The declaration was not adopted by the Quaker community and even forgotten, so that it was rediscovered twice (in 1844 and 2006) (Gerbner 2007, 150). Slavery continued in Quaker society and abolitionism remained an outsider position among Quakers for another hundred years. 
the reception of Averroism peaked around 1500, and several printed works appeared until the mid-sixteenth century, when the first chairs for Arabic were founded in Paris, Leiden, Cambridge, and Oxford (ibid., 385).

Interestingly enough, the impact of the translated works by philosophers and theologians such as Ibn Rushd, known as Averroes (d. 1198), and al-Kindī (d. 873) in Latin Christian Europe was much more profound than the reception of the original treatises in the centers of Arab and Muslim learning, where the manuscripts hardly found any readers and were re-discovered only in later centuries because of transmission in Latin Europe (ibid., 382f.; Kügelgen 1994). In Latin Europe, adherents and opponents of Averroism in scholastic as well as humanist circles eagerly received and discussed the pros and cons of theories put forward by al-Fārābī (d. 950), Ibn Sīnā, known as Avicenna (d. 1037), and Ibn Rushd-such as Ibn Rushd's theories about the "unity of the intellect"33 or the eternity of the world (Fakhry 2001; Haase 2013, 392-396). The translated Arabic texts played a central role in scholarly discussions for several centuries and forged the self-awareness of Christian and humanist scholars (ibid., 396); they were also appreciated by Jewish scholars, who followed the recommendations by Ibn Rushd's contemporary Maimonides to read them.

It is intriguing that these texts, which were widely circulated through Hebrew and Latin translations, created a positive image of the "rationality" of Muslim thought, although the multi-perspective, foundational discussion about the relation between reason and religion among Muslim authors from the eleventh to the fourteenth centuries (see Kügelgen 2010) was only fragmentarily known, some of the Arabic texts only partially translated, some of the circulating arguments misattributed, and their historical background misidentified or unknown. It is further intriguing that because of Ibn Rushd, Islamic philosophy stood as an antidote to religious strife, while Ibn Rushd himself might have been "an unexpected target of the anti-Jewish climate created by the Almohad authorities" (Serrano Ruano 2010, 230) and condemned along with several other philosophers. Ibn Rushd's fall from grace after 1194-obviously after an intrigue culminating in a caliphal decree accusing philosophers of being "worse than Christians and Jews" (ibid., 223)—was the result of a still unresolved, complex process that involved humiliating treatment of Ibn Rushd, accusations of unorthodox beliefs ("anthropomorphism"), and a rumor of his alleged Jewish ancestry. As his religious and intellectual integrity and his political loyalty were questioned, he was banished to Lucena, a small town traditionally populated mainly by Jews, for one-and-a-half years

33 Drawing on the universality of knowledge and the immateriality of the intellect, Averroes developed the theory of the unity of the human intellect, criticized by Thomas Aquinas (d. 1274) in De Unitate Intellectus, Contra Averroistas and condemned by the Catholic Church in Paris in 1270/1277 and again in Padua in 1489. 
and then summoned by the caliph to Marrakesh, where he died, never returning to Cordoba.

A telling example of the lack of this background knowledge is the image of Islam in the manuscript Colloquium Heptaplomeres ("The Colloquium of the Seven"), which has been called "one of the strangest and most fascinating texts written in early modern Europe" (Malcolm 2006, 95). The work, commonly attributed to French political philosopher Jean Bodin (d. 1596) (Malcolm 2006), was widely circulated, clandestinely, since the 1620 s before being printed in the mid-nineteenth century. It tries to solve the problem of how to deal with religious strife and a growing religious diversification in the course of the Reformation, and reproduces the debates of seven wise men-a Roman Catholic, a Lutheran, a Calvinist, a Jew, a Muslim, a natural philosopher, and a skeptic. In his search for models that could help Europeans solve the difficulties of multi-religious coexistence on the social, religious, and state level, the author heavily draws on examples from Antiquity but also from Judaism and Islam (Griffel 1999, 120). The image of Islam is that of a consistently tolerant religion $a b$ initio that allows the practice of foreign rites and forbids any quarrel about true religion. In the fourth book, the Muslim sage ("Octavius") claims that under the Turkish and Persian kings, who tolerate every form of religion, a harmony between citizens and foreigners prevails and reconciles the adherents of different religions with the state (ibid., 121). Thus, Islam comes close both to natural religion and the Bodin's ideal.

Griffel (1999, 131-142) has shown that Bodin knew only Ibn Rushd's main line of argumentation, but not al-Ghazālī's (d. 1111) arguments, which Ibn Rushd had criticized. Ibn Rushd's work Tahāfut al-tahāfut (ca. 1179 CE) was translated twice via Hebrew into Latin in 1328 and 1526, and printed as Destructio destructionum in 1497/1508 and six more times in the sixteenth century. Bodin obviously knew Ibn Rushd's argumentation, but mistook it for the position of Islam as such and had no idea about al-Ghazālī's, Avicenna's, or Ibn Taymiyya's positions, all of which had much more impact on the formation of Sunnī Islam (Griffel 1999; Kügelgen 2010). Bodin also seems to have taken the foundations of his own principle of toleration from Ibn Rushd, since his text reflects Ibn Rushd in three arguments, as Griffel $(1999,144)$ argues: All religions teach the same universal law and are only different ritual manifestations; these manifestations are intended to guide illiterate people to the moral law; although the educated can grasp the universal moral law behind these manifestations, they should avoid interpreting it for ordinary people and adopt the "most noble" among the religions of their time. Maybe Ibn Rushd's view about the difference between a theological and philosophical understanding of religion seemed attractive to Bodin because it may have helped him to differentiate the religious fanaticism of the "masses" during the Reformation from a pragmatic approach to religion advocated by literati like himself. 
That there was a discrepancy between the known historical facts and an idealized Islam in Latin Europe is even visible in the field of historiography. The Dutch Orientalist Thomas Erpenius (d. 1624) managed to translate the second part of the chronicle by the Egyptian Christian Jirjis b. al-'Amīd (known as al-Makīn, d. 1273) as Elmacin's Historia Saracenica (1625). With this work, Erpenius thought to provide a historical chronology of events since Muhammad unknown hitherto to European scholars. As he was unaware that the original text mainly drew on early Muslim sources, he actually made a "Muslim version of Muslim history available in Europe for the first time" (Irwin 2007, 103).

While the reception of Arab knowledge was controversial yet considered unavoidable in the emerging European scientific, philosophical, and medical landscape, the reception of the Qur'ān met with more reservations. Polemics against the person of Muhammad go way back to Johan of Damascus (d. 749), who already depicted Muhammad as a false prophet and the Antichrist and Muhammedan faith as a Christian heresy. The first "anti-hagiography" of Muhammad written north of the Alps in Latin can be attributed to a certain Embrico of Mainz, around 1100 (Tolan 1996). One of the most influential polemics ever written was Contra legem sarracenorum (ca. 1300), which was composed by the Italian Dominican monk Ricoldo da Monte di Croce (d. 1320) during or after his visit of Baghdad, first published as Confutatio Alcorani (1500) in Seville and translated into German by Martin Luther (d. 1546) as Verlegung des Alcoran (1542) (see Ehmann 1999; 2008). The polemics stressed the irrational and illogical character of Muhammad's teachings. In early book printing, illustrations of Muhammad visualized this message by depicting him as the false prophet, anti-hero, heretic, warrior, forger, Turk, and anti-Christ (Saviello 2015). These visualizations were meant to show the true picture of Muhammad; they took issue not only with his adherents' veneration for him, but also with a perceived Muslim lack of religious images. The prophetic iconography that circulated in the Turco-Persian and Mughal sphere since the mid-thirteenth century (Gruber and Shalem 2014) was mostly unknown to Europeans at that time. ${ }^{34}$

The first translation of the Qur'ān into Latin by Robert of Ketton in 1143 was appropriately titled "Lex Mahmut pseudoprophete" (Würsch 2013, 41). Petrus Venerabilis (d. 1156), Abbot of Cluny, who had ordered it in the aftermath of the first crusade (1096-1099), held the view that "the Islamic heresy" could only be defeated with the word, not with the sword. In spite of many shortcomings, this translation was considered authoritative by Latin Christians for 500 years and formed the foundation of the first print edition that the Zurich reformed theologian Theodor Bibliander (d.

34 The illustrations of the chronicle Jāmi` al-tawārīkh (1306-1311) (Blair 1995; Hillenbrand 2014), for example, contradict the cliché (widespread among both Muslims and non-Muslims) of a lack of religious images that has, purposefully or not, had the effect of eclipsing the artistic patrimony and visual imaginary within Islam (Gruber and Shalem 2014, 4). 
1564) initiated in Basel in 1543 (Bobzin 1995). That Bibliander himself added his own errors and misunderstandings to the text helps to identify, in the present, the chain of translations that have been based on his print (den Boer and Tommasino 2014, 470). The 1547 Italian translation Alcorano di Macometto by Giovanni Battista Castrodardo, printed in the smaller and cheaper quarto format, enjoyed much popularity among the literati all over Europe and the Mediterranean until 1643, when the first French translation appeared. The Italian version of Bibliander's work also fathered Dutch, Hebrew, and Spanish translations and formed the basis of the first German translation of the Qur'ān (1616, Nuremberg) that was accomplished by the Lutheran preacher Salomon Schweigger, who had learned Italian in Constantinople (ibid., 477).

That the Italian Alcorano was prohibited by the Tridentine Index (1546) shows that its sitz im leben was with the anti-Imperial and anti-Medici circles (ibid., 473-475), since the introduction by Castrodardo contained several anti-Imperial and pro-Ottoman notes. Its printer, Andrea Arrivabene, dedicated the work to the French ambassador to the Ottoman Empire, Gabriel de Luetz. ${ }^{35}$ The readers of Alcorano, both in Venice and Constantinople, consisted of political refugees, anti-Trinitarians, evangelical preachers, as well as Iberian Jewish refugees and conversos (Tommasino 2018, 9296). Among Sephardim Jews in Amsterdam, who had regular contact with the Maghreb and the Ottoman Empire, an increasing interest in the Qur'ān found its expression in the Spanish and Hebrew translation of the Italian Alcorano in the seventeenth century. Like anti-Catholic Qur'ān readers, rabbis and other Jewish authors found an ally in Islam that supported their argument against idolatry (den Boer and Tommasino 2014, 482). The Amsterdam Sephardi Jew Abraham Gómez Silveira (d. 1740), for example, depicted Islam as a rational religion-“only obscured, as are other religions, by human weakness" (ibid., 483). In witty dialogues between a reformed minister, a Catholic theologian, a Jew, and a Turk, the latter not only defends "monotheism, the human nature of Jesus, and the enduring validity of the Torah," but also speaks out "against enforced religion and he advocates natural law" (ibid.).

This was also the context in which Renaissance authors started to paint a new image of Muhammad as a "lawgiver" and "armed prophet" since the late fifteenth century; by focussing on his military and political achievements, they no longer portrayed Muhammad as a "pseudo-prophet," but as a gifted politican and successful builder of an empire, comparable to great Greek and Roman men (Tommasino 2018, 81-91). This background not only explains Niccolò Machiavelli's (d. 1527) several references to Muslim examples, but helps to restore "the centrality of his encounter

35 During the Schmalkaldic War (1546-1547), de Luetz embodied the hopes of anti-imperial groups who wanted to spread the Reformation on the Italian peninsula; during his stay in Constantinople (1547-1553), de Luetz negotiated an alliance with the Ottomans against the Imperial forces. 
with Islam and the East" (Biasiori and Marcocci 2018, 3) in his own works. In particular, Machiavelli's II Principe seems to be indebted to his knowledge of one of the Arab mirrors of princes, the Pseudo-Aristotelian Kitāb sirr al-asrār of eighth/ninth-century CE origin, which was not only "extremly popular in Europe" (Biasiori 2018, 18) but has been termed "the most popular book of the Middle Ages" (ibid.). Translated into Latin and entitled Secretum secretorum around 1125, "over 500 manuscript copies in European vernacular languages and 34 printed edition between 1472 and 1540 in Latin, Italian, German, English and French" (ibid.) are documented, and in Machiavelli's Florence 23 manuscripts have survived until today (ibid., 19). In this respect, "reorienting Machiavelli" (Biasiori and Marcocci 2018, 3) helps to underline the extent to which II Principe and Machiavelli's other works represent "pieces of a wider Eurasian mosaic ..., characterised by incessant political communication across linguistic, cultural and religious borders" (ibid.). Yet Machiavelli's contribution to modern political thought is still "typically reduced to a process entirely limited to the West" (ibid.), if not presented as an approach expressing "the supposed superiority of western values" (ibid.).

In spite of such early modern readings of the Qur'ān in Latin Europe, negative views of Islam prevailed; during the period usually called Enlightenment, a majority of European Qur'ān readers no longer based their prejudice on accusations of heresy but on the apparently boring style and awful language of the book (Wild 1994). However, there were also examples of a positive reception in the eighteenth and nineteenth centuries, such as the German poets Gotthold Ephraim Lessing (d. 1781) and Johann Wolfgang von Goethe (d. 1832), both of whom immersed themselves in studies of the Qur'ān and Muslim history. The judge's admonishment in Lessing's Nathan der Weise (1779) - that the three ring owners should not quarrel about who owned the right ring but compete with each other in performing good deeds-bears close resemblance to Qur'ānic verse 5:4836 (Fick 2017, 40f.; Kuschel 2011). In an announcement of his Westöstlicher Divan (1819, extended 1827), Goethe, in spite of his pantheistic inclinations, did not contradict the suspicion that he was a Mussulman himself (Mommsen 2001, 11). American novelist Washington Irving (d. 1859), whose work turned the Alhambra of Granada into a famous place of Western romantic yearnings, also composed a biography of Muhammad (1850, translated into in German the same year) in which he defended the prophet against the accusation of being an imposter. This work was among the sources from which Friedrich Nietzsche (d. 1900) developed his positive assessment of Islam (Figl 2008, 138f.). Nietzsche, in section 60 of his Antichrist, lamented that Christianity "robbed us of the harvest of the ancient world, and it later went on to rob us of the harvest of the culture of Islam" (quoted by Almond 2010, 157). Nietzsche 
considered "the wonderful Moorish cultural world of Spain, more closely related to us (...) than Greece and Rome" (ibid.), yet it had been "trampled down" by Christianity (ibid.). While the Orientalists of his time criticized Islam as fanatical, misogynic, unjust, and incapable of democracy, Nietzsche used it as "a positive example of a Semitic faith to show by contrast how weak and malign Christianity is" (ibid., 161). He lauded Islam as "more life-embracing and 'manly' than its Judeo-Christian sister-faiths" (ibid.). Although "Islam emerges in Nietzsche's work not as an affirmation of life in itself," it is "the closest thing to a jasagende affirmation the Semitic religions have to offer" (ibid.).

Studying ideas about Islam in the thought of eight German thinkers, from Leibniz to Nietzsche, Almond (2010) describes a polyphonic, complex struggle among them to come to terms with the "Mohammedan" Other and ends on the note-well-suited as a summary of the foregoing considerations-that a clearer understanding "will only take place once we stop thinking of authors as personalities who possess world-views, and start to see them as spaces in which discourses happens" (ibid., 163).

\section{Conclusion}

This article has tried to establish the distinction between the analytical category of Muslim space and the emergence of a trans-religious space, characterized by the circulation of ideas about Islam. In a first step, I aimed to problematize the notion of a Muslim world as a geographical, cultural, or trans-local conception in academic discourses. As a central problem in such conceptualizations, I have identified the different ways in which Islam is inscribed into space and history. My critique further tried to highlight that similar spatial mechanisms are at work when different actors and observers mark spaces-such as outer space, Europe, or the Middle East-as Islamic or un-Islamic or both at the same time. These include political and ritual practices, imagination, investment, planning, and popular use as well as scholarly debates. The scientific and legitimating use of outer space requires state investment in science. Populists who abominate the "Islamization" of Europe invest in mobilization in public space and social media. Muslim scholars who understand Europe as diaspora or a new homeland invest in institution-building and scholarly debate. Scholars of the Middle East try to convince the public as well as the academic community that the knowledge they produce about Islamic spaces is of importance.

In a second step, as a way of grasping the mutability of space and Islam, I have proposed a topological approach that leaves behind geographically or culturally defined space and focusses on the relational production of the (material, social, cultural, semiotic, economic, and political) dimensions of space. The argument was that the 
spatial expansion of Islam led to encounters between various "Others" and everchanging arrangements for these "Others" under Muslim rule. The lynchpin between the various historical examples on the previous pages was the idea that knowledge production about Islam created a trans-religious and transcultural space in which various imaginations of Islam came to circulate. The production of this multi-religious space is understood as the result of activities performed by Muslims and non-Muslims who perceive Islam, ascribe meaning to it, mark it, invest in it, or argue about it. This kind of approach does not look at isolated Muslim places and practices, but at human actions that constitute spatial relations and thereby a multi-religious topology of Islam. Some main reference points in this knowledge production-the position of Christians, Jews, and Șūfīs under Muslim rule or the anti-Trinitarian character and religious tolerance of Islam-were shared by Muslims and non-Muslims, although their meaning could strongly vary. Circulating in the global sphere over a long period of time, the notion of "Islam" has become a variegated object of global knowledge production. The continuous role that knowledge about Islam played in European debates has been at least partly forgotten or has sunken into oblivion altogether-although various actors have negotiated the idea of Islam with differing interests from the times of early Islam to the ages of Renaissance, Reformation, and Englightenment, and European colonialism to the independence of the United States.

This conception of a multi-religious space marks differences to other approaches in the studies of Islam. Although I am indebted to Shahab Ahmed (2016) and Thomas Bauer (2011) when it comes to the plural, if not contradictory, imaginations of Islam inside Muslim-majority societies, and to Cemil Aydin (2017) and Edward Said (1978) when it comes to the impact of Western perceptions of Islam especially in the nineteenth century, I detach neither Muslim negotiations of their understandings of Islam nor non-Muslim perceptions of Islam from their being situated in a cross-religious space. When Ahmed (2016) and Bauer (2011) support the idea that "contradictions" or "ambiguities" are inherent to Islam, the topological approach disagrees on three levels. Firstly, both authors do not dwell on the continuous historical transformations that can strengthen or dedifferentiate the underlying ambiguities. Secondly, they overestimate the pre-modern/modern divide that, according to them, created a modern Islam totally different from its pre-modern plural form. Thirdly, while they base the existence of Islamic contradictions/ambiguities on an intra-Islamic dynamism, they offer no place for the multi-religious diversity of Islamic landscapes-with the exception of modern Islam, whose emergence they do not explain by an intra-Islamic logic but mainly by extraIslamic factors, such as European colonialism and modernity. Although both authors try to grasp the totality of Islam, their approaches envision a kind of uniform space; even if this space is treated as consistently contradictory, this is not fully satisfying. The 
production and perception of space generally involves rugged, polycentric, dynamically changing, and hierarchical landscapes. Even given persistent Islamic ambiguities, it should be made visible that the practical effect of ambiguity was locally and historically differentiated, even in pre-modern times.

In a similar way, Aydin's (2017) thesis that "the idea of the Muslim world" resulted from nineteenth-century European-Muslim encounters that made Muslim élites adopt European ideas about themselves seems somewhat one-sided. Aydin's attempt to explain unpleasant developments of modern-violent, intolerant-understandings of Islam through the impact of Western colonialism shares with Ahmed (2016) and Bauer (2011) the ambivalent tone, since it can be read as an explanation of transcultural interconnections and power asymmetries, at best, or an exculpation, at worst.

The topological approach is also critical of the blunt rejection of "Orientalism" in the tradition of Edward Said (1978) that is premised on the spatial divide between Orient and Occident. Said dismissed the production of an imaginary Orient as a mere expression of Western domination, without considering that the production of space always incorporates boundary work and an imaginary dimension. His rejection of the Orientalist kind of image production does not acknowledge the partly positive ways in which a minority of European and American theologians, writers, scholars, and politicians engaged with Islam for various reasons (e.g. Irwin 2007), especially when trying to plead for tolerance and religious freedom. The criticism of one-sided Western image production neither recognizes circuits of knowledge production nor falsely positive, yet efficacious images of Islam.

Finally, the previous pages have shown that it has always been only a minority of non-Muslims who held a positive, or at least double-edged, view of Muhammad, the Saracens, the Turks, or Islam. Recently, Arshad et al. $(2015,18)$ have once again demonstrated, by way of a long-term analysis of New York Times headlines from 1990 to 2015, that Islam and Muslims-in contrast to Christians and Jews and a multitude of other nouns-are associated with negative terms so consistently that their image is even worse than that of cancer. ${ }^{37}$ From a historical point of view, the current prevalence of extremely negative tropes about Islam is no news and can be interpreted as the downside of Islam's global circulation as a mutable mobile, aggravated by reactions to recent acts of violence perpetrated in the name of Islam and by perceptions of problems of social cohesion in democratic societies.

37 Islam stood out as the term with the highest negative sentiment among all terms, scoring 57 percent of overall negative headlines versus 34 percent for cancer (total average: 29). Cancer also beat Islam with 17 percent of overall positive headlines versus eight (average: 14); only cocaine (seven percent) was rated lower than Islam. 
As a way of deepening the critique of one-sided-Muslim as well as non-Muslimrepresentations of Islam, this article has tried to underline the central place of Islam in European and global history as well as the multi-religious experiences in Islamic contexts and the cross-connection between both phenomena. It thus aimed to follow Coronil's (1996) critique of a historical disjunction between the producers and the objects of knowledge by underlining "the relational nature of representations of human collectivities" (Coronil 1996, 56). By treating "Islam" as a traveling, mutable mobile, my focus was not to explain that the dominance of certain imaginations and practices of Islam followed from "asymmetrical relations of power, including the power to obscure their genesis in inequality" (ibid.), since the existence of asymmetries inside and outside the territories under Muslim rule seems an obvious fact. Rather, my interest was to show that production-as well as dissemination, consumption, negotiation, destruction, and oblivion-of various imaginations of Islam created a global space. Thus, this article hopefully contributed to Coronil's critique of a historiography that presents "as the internal and separate attributes of bounded entities what are in fact historical outcomes of connected peoples" (ibid.). In this sense, the emergence of "Europe" and "Islam" as separate and antagonistic entities can also be seen as the effect not only of interrelations, but also of the circulation of ideas in a common space of knowledge production.

\section{Literature}

Abulafia, David. 2011. The Great Sea: A Human History of the Mediterranean. New York: Oxford University Press.

- - - 2012. "Aragon versus Turkey - Tirant lo Blanc and Mehmed the Conqueror. Iberia, the Crusade, and Late Medieval Chivalry." In Byzantines, Latins, and Turks in the Eastern Mediterranean World after 1150, edited by Jonathan Harris, Catherine Holmes, and Eugenia Russell, 291-312. Oxford: Oxford University Press.

Abu-Lughod, Janet. 1989. Before European Hegemony. The World System A.D. 12501350. New York.

Ágoston, Gábor. 2009. “Janissaries." In Encyclopedia of the Ottoman Empire, edited by Gábor Ágoston and Bruce Master, 296-297. New York: Facts on File.

Ahmed, Shahab. 2016. What Is Islam? The Importance of Being Islamic. Princeton, NJ.: Princeton University Press.

Al-Azmeh, Aziz. 1996. Die Islamisierung des Islams: Imaginäre Welten einer politischen Theologie. Frankfurt am Main: Campus. 
- - . 2003. "Postmodern Obscurantism and 'the Muslim Question'." Journal for the Study of Religions and Ideologies 5: 21-47.

Albrecht, Sarah. 2016. "Searching for the 'Homeland' of Islam. Concepts of Diaspora in Contemporary Islamic Discourse on Muslims in the West." Journal of Muslims in Europe 5: 106-131.

Almond, Ian. 2010. History of Islam in German Thought from Leibniz to Nietzsche. New York: Routledge.

Anthony, Sean W. 2011. "The Legend of 'Abdallāh ibn Saba' and the Date of the Umm al-Kitāb." Journal of the Royal Asiatic Society, Third Series, 21 (1): 1-30.

Arshad, Owais, Varun Setlur, and Usaid Siddiqui, Usaid. 2015: Are Muslims Collectively Responsible. A Sentiment Analysis of the New York Times. Accessed August, 15, 2018. http://416labs.com/nytandislam.

Aydin, Cemil. 2017. The Idea of the Muslim World: A Global Intellectual History. Cambridge, Mass.: Harvard University Press.

Bachmann-Medik, Doris. 2006. Cultural Turns: Neuorientierungen in den Kulturwissenschaften. Reinbeck: Rowohlt.

Baer, Marc. 2004. "The Double Bind of Race and Religion: The Conversion of the Dönme to Turkish Secular Nationalism." Comparative Studies in Society \& History 46 (4): 678-712.

- - . 2007. "An Enemy Old and New: The Dönme, Anti-Semitism, and Conspiracy Theories in the Ottoman Empire and Turkish Republic." Jewish Quarterly Review 103 (4): 523-555.

- - . 2008. Honored by the Glory of Islam: Conversion and Conquest in Ottoman Europe. New York: Oxford University Press.

-_- 2010. The Dönme: Jewish Converts, Muslim Revolutionaries, and Secular Turks. Stanford, Calif.: Stanford University Press.

Bauer, Thomas. 2011. Die Kultur der Ambiguität. Eine andere Geschichte des Islams. Berlin: Verlag der Weltreligionen.

Bashir, Shahzad. 2018. “Everlasting Doubt: Uncertainty in Islamic Representations of the Past." Archiv für Religionsgeschichte 20 (1): 25-44.

Beinhauer-Köhler, Bärbel. 2015. “Im Zwischenraum. Plurale Raumarrangements aus religionswissenschaftlicher Sicht." In Viele Religionen - ein Raum!? Analysen, Diskussionen und Konzepte, edited by Bärbel Beinhauer-Köhler, Mirko Roth, and Bernadette Schwarz-Boenneke, 55-76. Berlin: Frank \& Timme.

Bendixsen, Synnøve. 2013. The Religious Identity of Young Muslim Women in Berlin. Leiden: Brill.

Bennison, Amira K. 2007. "The Peoples of the North in the Eyes of the Muslims of Umayyad al-Andalus (711-1031)." Journal of Global History 2: 157-174. 
- - . 2010. "Almohad tawhīd and its Implications for Religious Difference." Journal of Medieval Iberian Studies 2 (2): 195-216.

Bennison, Amira K., and Maria Angeles Gallego. 2010. "Religious Minorities under the Almohads: An Introduction." Journal of Medieval Iberian Studies 2 (2): 143-154.

Berger, Maurits S. 2013. "The Third Wave: Islamization of Europe, or Europeanization of Islam?" Journal of Muslims in Europe 2: 115-136.

Biasiori, Lucio. 2018. "Islamic Roots of Machiavelli's Thought? The Prince and the Kitāb sirr al-asrār from Baghdad to Florence and Back." In Machiavelli, Islam and the East. Reorienting the Foundations of Modern Political Thought, edited by idem. and Giuseppe Marcocci, 17-36. Cham: Palgrave Macmillan.

Biasiori, Lucio, and Giuseppe Marcocci. 2018. "Introduction: Reorienting Machiavelli." In Machiavelli, Islam and the East. Reorienting the Foundations of Modern Political Thought, edited by idem., 1-13. Cham: Palgrave Macmillan.

Bietenholz, Peter G. 2009. Encounters with a Radical Erasmus. Erasmus' Work as a Source of Radical Thought in Early Modern Europe. Toronto: Toronto University Press.

Blair, Sheila. 1995. A Compendium of Chronicles. Rashid al-Din's Illustrated History of the World. London: Nour Foundation.

Bobzin, Hartmut. 1995. Der Koran im Zeitalter der Reformation. Studien zur Frühgeschichte der Arabistik und Islamkunde in Europa. Stuttgart: Franz Steiner.

Bonine, Michael E., Abbas Amant, and Michael Ezekiel Gaspar, eds. 2011. Is There a Middle East? The Evolution of a Geopolitical Concept. Stanford: Stanford University Press.

Bosworth, C.E. 2003. "Ḥarrān." Encyclopaedia Iranica. Accessed August, 25, 2018. http://www.iranicaonline.org/articles/harran.

Boušek, Daniel. 2011. "Polemics in the Age of Religious Persecutions: Maimonides' Attitude towards Islam." Asian and African Studies 20 (1): 46-85.

Böwering, Gerhard. 1983. "Abū Sa'īd Abī'l-Ḳayr." Encyclopaedia Iranica. Accessed August, 25, 2018. http://www.iranicaonline.org/articles/abu-said-fazlallah-b.

Bowman, Glenn, ed. 2012. Sharing the Sacra. The Politics and Pragmatics of Intercommunal Relations around Holy Places. New York: Berghahn Books.

Braudel, Fernand. 1979-1980. Civilisation matérielle, économie et capitalisme, XVe XVIIle siècle, 3 vols. Paris: Colin.

Braukämper, Ulrich. 2005. "Kulturkreis." In Wörterbuch der Völkerkunde, edited by Walter Hirschberg, 223-224. Berlin: Reimer.

Brubaker, Rogers, and Frederick Cooper. 2000. "Beyond 'identity'." Theory and Society 29: 1-47. 
Bruckmayr, Philipp. 2018. "Divergent processes of localization in twenty-first century Shi'ism: The Cases of Hezbollah Venezuela and Cambodia's Cham Shi'is." British Journal of Middle Eastern Studies, 45 (1): 18-38.

Bryce, Derek. 2013. "The Absence of Ottoman, Islamic Europe in Edward W. Said's Orientalism." Theory, Culture \& Society 30 (1): 99-121.

Budde, Gunilla, Sebastian Conrad, and Oliver Janz, eds. 2006. Transnationale Geschichte. Themen, Tendenzen und Theorien. Göttingen: Vandenhoeck \& Ruprecht.

Bulliet, Richard W. 1979. Conversion to Islam in the Medieval Period: An Essay in Quantitative History. Cambridge, Mass.: Cambridge University Press.

Burke III, Edmund. 2009. "Islam at the Center: Technological Complexes and the Roots of Modernity." Journal of World History 20 (2): 165-186.

-_- 2012. "Toward a Comparative History of the Mediterranean, 1750-1919." Journal of World History 23 (4): 907-939.

Clancy-Smith, Julia. 2010. Mediterraneans: North Africa and Europe in the Age of Migration, 1800-1900. Berkeley: University of California Press.

Clarence-Smith, William G. 2007. "Editorial - Islamic history as global history." Journal of Global History 2: 131-134.

Conermann, Stephan, ed. 1998. Der Indische Ozean in historischer Perspektive. Hamburg: E.B.-Verlag.

- - , ed. 2017. Muslim-Jewish Relations in the Middle Islamic Period. Jews in the Ayyubid and Mamluk Sultanates (1171-1517). Bonn: Bonn University Press.

Considine, Craig. 2018. Muslims in America. Examining the Facts. Santa Barbara: ABCClio.

Corcos, David. 2010. "The Nature of the Almohad Rulers' Treatment of the Jews." Journal of Medieval Iberian Studies 2 (2): 259-285.

Coronil, Fernando. 1996. “Beyond Occidentalism: Toward Non-Imperial Geohistorical Categories." Cultural Anthroplogy 11 (1): 51-87.

Courbage, Youssef and Philippe Fargues. 1997. Christians and Jews under Islam. London: I.B. Tauris.

Couroucli, Maria. 2012. "Sharing Sacred Places - A Mediterranean Tradition." In Sharing Sacred Spaces in the Mediterranean: Christians, Muslims, and Jews at Shrines and Sanctuaries, edited by Dionigi Albera and Maria Couroucli, 1-9. Bloomington: Indiana University Press.

Crone, Patricia. 1991. „Mawlā.“ In The Encyclopaedia of Islam, 2nd ed, vol. VI, edited by P. Bearman, Th. Bianquis, C.E. Bosworth, E. van Donzel, and W.P. Heinrichs, 874a-882b. Leiden: Brill. 
Cuffel, Alexandra. 2003. “'Henceforward all generations will call me blessed': Medieval Christian Tales of Non-Christian Marian Veneration." Mediterranean Studies 12: 37-60.

- - . 2005. “From Practice to Polemic: Shared Saints and Festivals as 'Women's Religion' in the Medieval Mediterranean." Bulletin of the School of Oriental and African Studies 68 (3): 401-419.

Curtis IV, Edward E. 2009. Muslims in America. A Short History. Oxford: Oxford University Press.

Davis, Natalie Z. 2006. Trickster Travels: A Sixteenth-Century Muslim between Worlds. New York: Hill and Wang.

Davison, Roderic H. 1960. "Where Is the Middle East?" Foreign Affairs 38 (4): 665-675. Den Boer, Harm, and Pier Mattia Tommasino (2014): "Reading the Qur'ān in the $17^{\text {th }}$ Century Sephardi Community of Amsterdam." Al-Qantara 35 (2): 461-491.

Determann, Jörg Matthias. 2018. Space Science and the Arab World. Astronauts, Observatories and Nationalism in the Middle East. London: I.B. Tauris.

Deutsch, Jan-Georg, and Brigitte Reinwald, eds. 2002. Space on the Move: Transformations of the Indian Ocean Seascape in the Nineteenth and Twentieth Century. Berlin: Schwarz.

Dörfler, Thomas. 2010. "Raumtheorie nach dem spatial turn." In Gentrification in Prenzlauer Berg? Milieuwandel eines Berliner Sozialraums seit 1989, edited by Thomas Dörfler, 16-89, Bielefeld: transcript.

Dressler, Markus. 2005. "Inventing Orthodoxy: Competing Claims for Authority and Legitimacy in the Ottoman-Safavid Conflict." In Legitimizing the Order. The Ottoman Rhetoric of State Power, edited by Hakan T. Karateke and Maurus Reinkowski, 151-173. Leiden: Brill.

- - . 2010. "How to Conceptualize Inner-Islamic Plurality/Difference: 'Heterodoxy' and 'Syncretism' in the Writings of Mehmet F. Köprülü (1890-1966)." British Journal of Middle Eastern Studies 37 (3): 241-260.

- - . 2013. Writing Religion. The Making of Turkish Alevism. New York: Oxford University Press.

Eaton, Richard M. 1993. "Islamic History as Global History." In Islamic and European Expansion: The Forging of a Global Order, edited by Michael Adas, 1-35. Philadelphia: Temple University Press.

Ehmann, Johannes. 1999. Confutatio Alcorani (1300)/Verlegung des Alcoran (1542): Kommentierte lateinisch-deutsche Textausgabe. Wiesbaden: Echter-Verlag.

-_- 2008. Luther, Türken und Islam: eine Untersuchung zum Türken- und Islambild Martin Luthers (1515-1546). Gütersloh: Gütersloher Verlagshaus. 
Elmarsafy, Ziad. 2009. The Enlightenment Qur'an: The Politics of Translation and the Construction of Islam. Oxford: One World.

Elverskog, Johan. 2010. Buddhism and Islam on the Silk Road. Philadelphia: University of Pennsylvania Press.

Ende, Werner. 1977. Arabische Nation und islamische Geschichte. Die Umayyaden im Urteil arabischer Autoren des 20. Jahrhunderts. Beirut: Steiner.

Escher, Anton. 2016. "Geographie des islamischen Raumes." In Der Islam. Einheit und Vielfalt einer Weltreligion, edited by Rainer Brunner, 11-43. Stuttgart: Kohlhammer.

Esposito, John, ed. 2009. The Oxford Encyclopedia of the Islamic World. New York: Oxford University Press.

Fakhry, Majid. 2001. Averroes (Ibn Rushd): His Life, Works, and Influence. Oxford: Oneworld.

Fenton, Paul B. 2017. "Sufis and Jews in Mamluk Egypt." In Conerman 2017, 41-62.

Fick, Monika. 2017. "Lessings Nathan der Weise und das Bild vom Orient und Islam in Theatertexten aus der zweiten Hälfte des 18. Jahrhunderts." In Goethezeitportal. February 15, 2017. http://www.goethezeitportal.de/db/wiss/ lessing/fick_orient.pdf.

Figl, Johann. 2008. Nietzsche und die Religionen: Transkulturelle Perspektiven seines Bildungs- und Denkweges. Berlin: De Gruyter.

Firges, Pascal. 2017. French Revolutionaries in the Ottoman Empire: Diplomacy, Political Culture, and the Limiting of Universal Revolution, 1792-1798. Oxford: Oxford University Press.

Fischer, Niels. 2008. "Islamic Religious Practice in Outer Space." ISIM Review 22: 39.

Fowden, Elizabeth Key. 1999. "Sharing Holy Places." Common Knowledge 8 (1): 124146.

Frank, André Gunder. 1998. ReOrient: Global Economy in the Asia Age. Berkely: University of California Press.

Frankopan, Peter. 2015. The Silk Roads. A New History of the World. London: Bloomsbury. Freitag, Ulrike. 2003. Indian Ocean Migrants and State Formation in Hadhramaut. Leiden: Brill.

Freitag, Ulrike, and Achim von Oppen. 2010. “'Translocality'. An Approach to Connection and Transfer in Regional Studies. Introduction." In Translocality. The Study of Globalising Processes from a Southern Perspective, edited by Ulrike Freitag and Achim von Oppen, 1-24. Leiden: Brill.

Frobenius, Leo. 1898. Der Ursprung der afrikanischen Kulturen. Berlin: Borntraeger.

Garcia, Humberto. 2012. Islam and the English Enlightenment. Baltimore: Johns Hopkins University Press. 
Gebauer, Matthias, and Shadia Husseini de Araújo. 2016. “Islamic Shores Along the Black Atlantic. Analysing Black and Muslim Countercultures in Post-Colonial Societies." Journal of Muslims in Europe 5: 11-37.

Gerbner, Katherine. 2007. '“We are against the Traffik of Men-Body.' The Germantown Quaker Protest of 1688 and the Origins of American Abolitionism." Pennsylvania History 74 (2): 149-172.

Goitein, Shlomo D. 1967-1988. A Mediterranean Society. The Jewish Communities of the Arab World as portrayed in the Documents of the Cairo Geniza, 6 vols. Berkeley: University of California Press.

Goldziher, Iganz. 1903. "Über den Einfluss des Buddhismus auf den Islam," übersetzt und kommentiert von Markus Groß. Accessed August 25, 2018. http:// inarah.de/sammelbaende-und-artikel/inarah-band-4/ueber-den-einfluss-desbuddhismus-auf-den-islam.

Gordon-Reed, Annette. 2008. The Hemingses of Monticello. New York: Norton.

Graf, Tobias P. 2017. The Sultan's Renegades. Christian-European Converts to Islam and the Making of the Ottoman Elite, 1575-1610. Oxford: Oxford University Press.

Graham-Harrison, Emma, and Joshua Surtees. 2018. “Trinidad's Jihadis: How Tiny Nation Became ISIS Recruiting Ground. The Caribbean nation has one of the world's highest Isis volunteer rates - and most don't come back." Guardian. February 2, 2018. https://www.theguardian.com/world/2018/feb/02/trinidadjihadis-isis-tobago-tariq-abdul-haqq.

Green, Nile. 2014. "Rethinking the 'Middle East' after the Oceanic Turn." Comparative Studies of South Asia, Africa and the Middle East 34 (3): 556-564.

Green, Tamara M. 1992. The City of the Moon God, Leiden: Brill.

Griffel, Frank. 1999. "Toleranzkonzepte im Islam und ihr Einfluß auf Jean Bodins Colloquium Haptaplomeres." In Bodinus Polymeres. Neue Studien zu Jean Bodins Spätwerk, edited by Ralph Häfner, 119-144. Wiesbaden: Harrassowitz.

- - . 2017. "Contradictions and Lots of Ambiguity: Two New Perspectives on Premodern (and Postclassical) Islamic Societies. Review Article of Shahab Ahmed's 'What is Islam?' and Thomas Bauer's 'Kultur der Ambiguität'." Bustan: The Middle East Book Review 8 (1): 1-21.

Gruber, Christiane, and Avinoam Shalem. 2014. "Introduction: Images of the Prophet Muhammad in a Global Context." In The Image of the Prophet between Ideal and Ideology. A Scholarly Investigation, edited by Christian Gruber and Avinoam Shalem, 1-9. Berlin: De Gruyter.

Guessoum, Nidhal. 2013. "Time for an Arab astronomy renaissance." Nature 498: 161164. 
Gürkan, Emrah Safa. 2010. "Christian Allies of the Ottoman Empire." European History Online (EGO), published by the Institute of European History (IEG), Mainz. December 03, 2010. http://www.ieg-ego.eu/gurkane-2010-en.

Günzel, Stephan. 2017. Raum. Eine kulturwissenschaftliche Einführung. Bielefeld: transcript.

Hacısalihoğlu, Mehmet. 2007. "Inclusion and Exclusion: Conscription in the Ottoman Empire." Journal of Modern European History 5 (2): 264-286.

Hadjikyriacou, Antonis. 2016a. "The Province Goes to the Center. The Case of Hadjiyorgakis Kornesios, Dragoman of Cyprus." In Living in the Ottoman Realm. Empire and Identity, 13th to 20th Centuries, edited by Christine IsomVerhaaren and Kent F. Schull, 239-251. Bloomington: Indiana University Press.

- - . 2016b. "The Ottomanization of Cyprus: Towards a Spatial Imagination Beyond the Center-Province Binary." Journal of Mediterranean Studies 25 (2): 81-96.

Hashas, Mohammed. 2013. On the Idea of European Islam. Voices of Perpetual Modernity, Rome. Accessed August, 15, 2018. https://eprints.luiss.it/1237/1/20130603hashas.pdf

Hasluck, Frederick W. 1929. Christianity and Islam under the Sultans, 2 vols. Oxford: At the Clarendon Press.

Hasse, Dag N. 2013. "Die Überlieferung arabischer Philosophie im lateinischen Westen." In Islamische Philosophie im Mittelalter. Ein Handbuch, edited by Heidrun Eichner, Matthias Perkams, and Christian Schäfer, 377-400. Darmstadt: Wissenschaftliche Buchgesellschaft.

Hayden, Robert M. 2002. "Antagonistic Tolerance. Competitive Sharing of Religious Sites in South Asia and the Balkans." Current Anthropology 43 (2): 205-231.

Helmedach, Andreas, Markus Koller, Konrad Petrovszky, and Stefan Rohdewald. 2013. "Das osmanische Europa als Gegenstand der Forschung." In Das osmanische Europa: Methoden und Perspektiven der Frühneuzeitforschung zu Südosteuropa, edited by Andreas Helmedach, Markus Koller, Konrad Petrovszky, and Stefan Rohdewald, 9-23. Leipzig: Eudora-Verlag.

Hillenbrand, Robert. 2014. "Muhammad as Warrior Prophet. Images from the World History of Rashid al-Din." In The Image of the Prophet between Ideal and Ideology. A Scholarly Investigation, edited by Christiane Gruber and Avinoam Shalem, 65-75. Berlin: De Gruyter.

Hodgson, Marshal G.S. 1974. The Venture of Islam, 3 vols. Chicago: Chicago University Press.

--_. 1993. Rethinking World History. Essays on Europe, Islam, and World History, edited by Edmund Burke III. Cambridge: Cambridge University Press. 
Holmes, Catherine. 2012. "Introduction." In Byzantines, Latins, and Turks in the Eastern Mediterranean World after 1150, edited by Jonathan Harris, Catherine Holmes, and Eugenia Russell, 1-29. Oxford: Oxford University Press.

Horden, Peregrine, and Nicolas Purcell. 2000. The Corrupting Sea: A Study of Mediterranean History. Oxford: Blackwell.

Houghton, H.A.G. 2016. The Latin New Testament: A Guide to its Early History, Texts, and Manuscripts. Oxford Scholarship Online. DOI: 10.1093/acprof:0 so/9780198744733.001.0001.

Hoyland, Robert G. 2011. "The Jews of the Hijaz in the Qur'ān and in their Inscriptions." In New Perspectives on the Qur'ān. The Qur'ān in its Historical Context 2, edited by Gabriel S. Reynolds, 91-116. London: Routledge.

Huntington, Samuel P. 1996. The Clash of Civilizations and the Remaking of World Order. New York: Simon \& Schuster.

Husayn, Fālih. 2012. "The Participation of Non-Arab Elements in the Umayyad Army and Administration. Translated by Emran El-Badawi and Fred M. Donner." In The Articulation of Early Islamic State Structures, edited by Fred M. Donner, 265289. Surrey: Ashgate.

Ibn 'Arabī, Muḥyī al-Dīn. 1911. The Tarjūmān al-Ashwāq, A Collection of Mystical Odes by Muhyî'ddīn ibn al-'Arabī, edited and translated by Richard A. Nicholson, London. Accessed August, 20, 2018. https://www.sacred-texts.com/isl/taa/ index.htm.

Irwin, Robert. 2007. For Lust of Knowing: The Orientalists and their Enemies. London: Penguin Books.

Jackson, Peter. 2017. The Mongols and the Islamic World. From Conquest to Conversion. New Haven: Yale University.

Jankowiak, Marek. 2017. "What Does the Slave Trade in the Saqaliba Tell US about Early Islamic Slavery?" International Journal of Middle East Studies 49: 169-172.

Jaschok, Maria, and Shui Jingjun. 2000. The History of Women's Mosques in Chinese Islam. A Mosque of Their Own. Richmond: Curzon.

Kafadar, Cemal. 1995. Between Two Worlds: The Construction of the Ottoman State. Berkeley, Calif: University of California Press.

Kaplony, Andreas. 2016. “Die Arabisierung der frühislamischen Verwaltung SyrienPalästinas und Ägyptens im Spiegel der zweisprachigen griechisch-arabischen Dokumente (550-750): ein Plädoyer für einen regionalen Ansatz." In Denkraum Spätantike. Reflexionen von Antiken im Umfeld des Koran, edited by Nora Schmidt, Nora K. Schmid, and Angelika Neuwirth, 387-404. Wiesbaden: Harrassowitz. 
Kavas, Ahmet. 2007. "Ottoman Empire's Relations with Southern Africa." Journal of the Faculty of Divinity of Ankara University 48 (2): 11-20.

Khalidi, Rashid. 1998. "The 'Middle East' as a Framework of Analysis: Re-Mapping a Region in the Era of Globalization." Comparative Studies of South Asia, Africa and the Middle East 17 (1): 74-80.

Kidd, Thomas S. 2003. "'Is It Worse to Follow Mahomet than the Devil?' Early American Uses of Islam." Church History 72 (4): 766-790.

Kieser, Hans-Lukas. 2001. "Muslim Heterodoxy and Protestant Utopia. The Interactions between Alevis and Missionaries in Ottoman Anatolia." Die Welt des Islams 41 (1): 89-111.

König, Daniel G. 2010. “Muslim Perception(s) of 'Latin Christianity': Methodological Reflections and a Reevaluation." In Labeling the Religious Self and Others: Reciprocal Perceptions of Christians, Muslims, Hindus, Buddhists, and Confucians in Medieval and Early Modern Times, edited by Hans Martin Krämer et al., 18-42. Comparativ. Zeitschrift für Globalgeschichte und vergleichende Gesellschaftsforschung.

-_- 2017. "Rezension zu: Bruce, Scott G.: Cluny and the Muslims of La Garde-Freinet. Hagiography and the Problem of Islam in Medieval Europe." H-Soz-Kult. April 26, 2017. https://www.hsozkult.de/publicationreview/id/rezbuecher-26136.

Knott, Kim. 2005. "Spatial theory and method for the study of religion." Temenos 41 (2): 153-184.

- - . 2009. "From locality to location and back again: A spatial journey in the study of religion," Religion 39: 154-60.

Konrad, Felix. 2010. "Soziale Mobilität europäischer Renegaten im frühneuzeitlichen Osmanischen Reich." In Religion und Mobilität. Zum Verhältnis von raumbezogener Mobilität und religiöser Identitätsbildung im frühneuzeitlichen Europa, edited by Henning P. Jürgens and Thomas Weller, 213-234. Göttingen: Vandenhoeck \& Ruprecht.

-_- 2011. "From the 'Turkish Menace' to Exoticism and Orientalism: Islam as Antithesis of Europe (1453-1914)?" European History Online (EGO), edited by the Institute of European History (IEG). March 14, 2011. http://www.ieg-ego.eu/ konradf-2010-en.

Koren, Marina. 2018. "The Middle East's Growing Space Ambitions." The Atlantic. June 4, 2018. https://www.theatlantic.com/science/archive/2018/06/middle-eastspace-ambitions/561776.

Kramer, Martin. 1999. "Introduction." In The Jewish Discovery of Islam. Studies in Honor of Bernard Lewis, edited by Martin Kramer, 1-48. Tel Aviv: Moshe Dayan Center of Middle Eastern and African Studies. 
Kreyenbroek, Philip G. 1995. Yezidism - Its Background, Observances and Textual Tradition. Lewiston, NY: Edwin Mellen Press.

- - . 2005. "Religious Minorities in the Middle East and Transformation of Rituals in the Context of Migration." In Migration und Ritualtransfer: Religiöse Praxis der Aleviten, Jesiden und Nusairier zwischen Vorderem Orient und Westeuropa, edited by Robert Langer, Raoul Motika, and Michael Ursinus, 31-50. Frankfurt am Main: Peter Lang.

Krstić, Tijana. 2011. Contested Conversions to Islam: Narratives of Religious Change in the Early Modern Ottoman Empire. Stanford, Calif.: Stanford University Press.

-_- 2015. "Islam and Muslims in Europe." In The Oxford Handbook of Early European Modern History, 1350-1750: Volume I: Peoples and Place, edited by Hamish Scott 670-693. Oxford: University Press.

Kügelgen, Anke von. 1994. Averroes und die arabische Moderne. Ansätze zu einer Neubegründung des Rationalismus im Islam. Leiden: Brill.

- - . 2010. "Muslimische Theologen und Philosophen im Wett- und Widerstreit um die Ratio - Ein Thesenpapier zum Diktum der 'Vernunftreligion' Islam im 11.14. Jahrhundert." Asiatische Studien 64 (3): 601-648.

Kuschel, Karl-Josef. 2011. Im Ringen um den wahren Ring: Lessings "Nathan der Weise“ - eine Herausforderung der Religionen. Ostfildern: Patmos.

Lafi, Nora. 2014. "The Eighteenth Century in the Arab Provinces of the Ottoman Empire: Perspectives for a Global History." In Cultural Transfer, Encounters and Connections in the Global 18th Century, edited by Matthias Middell, 231-260. Leipzig: Leipziger Universitätsverlag.

Lang, Isabel. 2015. Intertextualität als hermeneutischer Zugang zur Auslegung des Korans. Eine Betrachtung am Beispiel der Verwendung von Isrā'īīyāt in der Rezeption der Davidserzählung in Sure 38: 21-25. Berlin: Logos.

Langer, Robert. 2010. “Yezidism between Scholarly Literature and Actual Practice: From 'Heterodox' Islam and 'Syncretism' to the Formation of a Transnational Yezidi 'Orthodoxy'." British Journal of Middle Eastern Studies 37 (3): 393-403.

Langer, Robert, and Udo Simon. 2008. "The Dynamics of Orthodoxy and Heterodoxy. Dealing with Divergence in Muslim Discourses and Islamic Studies." Die Welt des Islams 48 (3/4): 273-288.

Langer, Robert, and Benjamin Weineck. 2017. “Shiite 'Communities of Practice' in Germany. Researching Multi-Local, Heterogeneous Actors in Transnational Space." Journal of Muslims in Europe 6: 216-240.

Langer, Robert, Raoul Motika, and Michael Ursinus, eds. 2005. Migration und Ritualtransfer: Religiöse Praxis der Aleviten, Jesiden und Nusairier zwischen Vorderem Orient und Westeuropa. Frankfurt am Main: Peter Lang. 
Lapidus, Ira. 1989. A History of Islamic Societies. Cambridge: Cambridge University Press.

Lawton, John, and Patricia Moody. 1986. "A Prince in Space." Aramco World (January/ February). Accessed July, 12, 2018. http://archive.aramcoworld.com/ issue/198601/a.prince.in.space.htm.

Lecker, Michael. 1985. "Muḥammad at Medina: A Geographical Approach." Jerusalem Studies in Arabic and Islam 6: 29-62.

-_- 1995a: Muslims, Jews, and Pagans. Studies on Early Islamic Medina. Leiden: Brill.

- - . 1995b. "On Arabs of the Banū Kilāb Executed Together with the Jewish Banū Qurayza." Jerusalem Studies in Arabic and Islam 19: 66-72.

- - - 2012. "Constitution of Medina." In Encyclopaedia of Islam³, edited by Kate Fleet, Gudrun Krämer, Denis Matringe, John Nawas, and Everett Rowson, 100-104. Leiden: Brill.

- - . 2016. "Were There Female Relatives of the Prophet Muhammad among the Besieged Qurayẓa." Journal of the American Oriental Society 136 (2): 397-404.

-_- 2017. "The Monotheistic Cousins of Muḥammad's Wife Khadīja." Der Islam 94 (2): 363-384.

Lefebvre, Henri. 1974. La production de l'espace. Paris: Anthropos.

Lewis, Cathleen S. 2013. "Muslims in Space: Observing Religious Rites in a New Environment." Astropolitics 11 (1-2): 108-115.

Lipton, Gregory A. 2011. "Secular Sufism: Neoliberalism, Ethnoracism, and the Reformation of the Muslim Other." Muslim World 101: 427-440.

- - . 2017. "De-Semitizing Ibn 'Arabī: Aryanism and the Schuonian Discourse of Religious Authenticity." Numen 64: 258-293.

-_- 2018. Rethinking Ibn 'Arabi. New York: Oxford University Press.

Loimeier, Roman. 2009. "Editorial" (Islam in Contemporary West Africa: Literature, Orality and Law). Die Welt des Islams 49 (3/4): 287-298.

- - . 2013. "Is There an 'African' Islam." In Muslim Societies in Africa: A Historical Anthropology, by Roman Loimeier, 11-34. Bloomington, Ind.: Indian University Press.

Lorcin, Patricia M.E., and Todd Shepard. 2016. French Mediterraneans. Transnational and Imperial Histories. Lincoln and London: University of Nebraska Press.

Löw, Martina. 2001. Raumsoziologie. Frankfurt am Main: Suhrkamp.

Lüling, Günter. 1993. Über den Urkoran. Ansätze zur Rekonstruktion der vorislamischchristlichen Strophenlieder im Koran. Erlangen: Verlagsbuchhandlung H. Lüling. Meggitt, Justin J. 2013. Early Quakers and Islam. Slavery, Apocalyptic and ChristianMuslim Encounters in the Seventeenth Century. Uppsala: Swedish Science Press. 
Malcolm, Noel. 2006. "Jean Bodin and the Authorship of the Colloquium Heptaplomeres." Journal of the Warburg and Courtauld Institutes 69: 95-150.

Marcotte, Roxanne D. 2001. "Suhrawardi al-Maqtul, The Martyr of Aleppo." Al-Qantara, 22 (2): 395-419.

Massignon, Louis. 1975. La passion de Husayn Ibn Mansûr Hallâj : martyr mystique de I'Islam exécuté à Bagdad le 26 mars 922 ; étude d'histoire religieuse. 4 volumes. Paris: Gallimard.

Masters, Bruce. 2001. Christians and Jews in the Ottoman Arab World: The Roots of Sectarianism. Cambridge: Cambridge University Press.

Mastnak, Tomaž. 1994. "Fictions in Political Thought. Las Casas, Sepúlveda, the Indians, and the Turks." Filozofski Vestnik 15: 127-149.

Masuzawa, Tomoko. 2005. The Invention of World Religions: Or, How European Universalism Was Preserved in the Langue of Pluralism. Chicago: University of Chicago Press.

McCormick, Michael. 2001. Origins of European Economy. Communications and Commerce, $A D$ 300-900. Cambridge: Cambridge University Press.

McDonald, Grantley. 2017. "The Johannine Comma from Erasmus to Westminster." In Scriptural Authority and Biblical Criticism in the Dutch Golden Age: God's Word Questioned, edited by Dirk van Miert, Henk Nellen, Piet Steenbakkers, and Jetze Touber. Oxford Scholarship Online. DOI:10.1093/oso/9780198806837.003.0003.

Mielke, Katja, and Anna-Katharina Hornidge. 2014. “Crossroads Studies: From Spatial Containers to Interactions in Differentiated Spatialites. 'Area Studies'-Discussion Paper of the Research Network Crossroads Asia." Crossroads Asia Working Paper Series. Accessed December 15, 2018. https://d-nb.info/1112962972/34.

Mojaddedi, Jawid. 2013. "Ḥallāj, Abū I-Moḡiṭ Hosayn." Encyclopaedia Iranica. Accessed August, 25, 2018. http://www.iranicaonline.org/articles/hallaj-1.

Mommsen, Katharina. 2001. Goethe und der Islam. Frankfurt am Main: Insel.

Munt, Harry. 2015. “'No two religions': Non-Muslims in the early Islamic Ḥijāz." Bulletin of SOAS 78 (2): 249-269.

Nawas, John A. 1994. "Reexamination of Three Current Explanations for al-Ma'mun's Introduction of the Mihna." International Journal of Middle East Studies 26 (4): 615-629.

Noth, Albrecht. 1978. “Möglichkeiten und Grenzen islamischer Toleranz.” Saeculum 29: 190-204.

Nicholson, Reynold A. 1914: The Mystics of Islam. London: Bell and Sons.

O'Fahey, R.S., and Bernd Radtke. 1993. "Neo-Sufism Reconsidered." Der Islam 70: 5287. 
Onnudottir, Helena, Adam Possamai, and Bryan Turner. 2012. "Islam and Indigenous Populations in Australia and New Zeeland." In Muslims in the West and the Challenges of Belonging, edited by Fethi Mansouri and Vince Marotta, 60-86. Carlton, Vic.: Melbourne University Press.

Østebø, Terje. 2012. Localising Salafism. Religious Change among Oromo Muslims in Bale, Ethiopia. Leiden: Brill.

Pagden, Anthony. 1987. "Dispossessing the Barbarian: The Language of Spanish Thomism and the Debate over the Property Rights of the American Indians." In The Languages of Political Theory in Early-Modern Europe, edited by Anthony Pagden, 79-98. Cambridge: Cambridge University Press.

Peirce, Leslie P. 1993. The Imperial Harem: Women and Sovereignty in the Ottoman Empire. New York: Oxford University Press.

Peleikis, Anja. 2001. "Shifting Identities, Reconstructing Boundaries. The Case of a Multi-Confessional Locality in Post-War Lebanon." Die Welt des Islams 41 (3): 400-429.

Pink, Johanna. 2016. "Islam und Nichtmuslime." In Islam. Einheit und Vielfalt einer Weltreligion, edited by Rainer Brunner, 481-500. Stuttgart: Kohlhammer.

Poppe, Patrick. 2014. "Radix Turcorum, radix Mahumeti? Entstehungs- und Herkunftsdiskurse über den Islam im Kontext des Falls von Konstantinopel (1453)." In Die Entstehung einer Weltreligion III. Die heilige Stadt Mekka - eine literarische Fiktion (Inârah-Sammelband 7), edited by Markus Groß and KarlHeinz Ohlig, 392-420. Berlin: Schiler.

Pratt, Mary L. 1991: “Arts of the Contact Zone." Profession 91: 33-40.

Radtke, Bernd. 1994. "Warum ist der Sufi orthodox?" Der Islam 71: 302-307.

Ralston, Joshua. 2017. "Islam as Christian Trope: The Place and Function of Islam in Reformed Dogmatic Theology." The Muslim World 107: 754-776.

Reichmuth, Stefan. 2000. “'Netzwerk' und 'Weltsystem'. Konzepte zur neuzeitlichen 'Islamischen Welt' und ihrer Transformation." In Die islamische Welt als Netzwerk. Möglichkeiten und Grenzen des Netzwerkansatzes im islamischen Kontext, edited by Roman Loimeier, 53-86. Würzburg: Ergon.

Reinkowski, Maurus. 2013. “Keine Kryptoreligion, aber doch kryptoreligiös. Zur Frage einer realen Existenz von Kryptojuden und Kryptochristen im islamisch überprägten Mittelmeerraum und Nahen Osten." In Konfessionelle Ambiguität. Uneindeutigkeit und Verstellung als religiöse Praxis in der Frühen Neuzeit, edited by Andreas Pietsch and Barbara Stollberg-Rilinger, 75-98. Gütersloh: Gütersloher Verlagshaus.

-_- 2017. “Ein neuer Naher Osten? Zur realen Krise eines epistemischen Systems.” Leviathan 31: 95-113. 
Rudolph, Ulrich. 1994. "Nikolaus von Kues und der Dialog mit dem Islam." Der Islam 71: 95-108.

Said, Edward. 1978. Orientalism. New York: Pantheon Books.

Saviello, Alberto. 2015. Imaginationen des Islam: Bildliche Darstellungen des Propheten Mohammed im westeuropäischen Buchdruck bis ins 19. Jahrhundert. Berlin: De Gruyter.

Scharbrodt, Oliver. 2018. "A Minority within a Minority?: The Complexity and Multilocality of Transnational Twelver Shia Networks in Britain." Contemporary Islam. November 8, 2018. https://doi.org/10.1007/s11562-018-0431-0.

Schölch, Alexander. 1975. "Wirtschaftliche Durchdringung und politische Kontrolle durch die europäischen Mächte im Osmanischen Reich (Konstantinopel, Kairo, Tunis)." Geschichte und Gesellschaft 1: 404-446.

Serrano Ruano, Delfina. 2010. “Explicit Cruelty, Implicit Compassion: Judaism, Forced Conversions and the Genealogy of the Banū Rushd." Journal of Medieval Iberian Studies 2 (2): 217-233.

Sharkey, Heather. 2017. A History of Muslims, Jews, and Christians in the Middle East. Cambridge: Cambridge University Press.

Simonsohn, Uriel. 2017. "Communal Boundaries Reconsidered. Jews and Christians Appealing to Muslim Authorities in the Medieval Near East." Jewish Studies Quarterly 14 (4): 328-363.

Spellberg, Denise. 2006. "Could a Muslim be President? An Eighteenth-Century Constitutional Debate." Eighteenth-Century Studies 39 (4): 485-506.

- - . 2013. Thomas Jefferson's Qur'an: Islam and the Founders. New York: Vintage Books.

Spivak, Gayatri C. 1993. "Can the Subaltern Speak?" In Colonial Discourse and PostColonial Theory: A Reader, edited by Laura Chrisman and Patrick Williams, 66111. New York: Harvester Wheatsheaf.

Stewart. 2008. "The Ottoman Execution of Zayn al-Dīn al-'Āmilī." Die Welt des Islams 48 (3): 289-347.

Svanberg, Ingvar, and David Westerlund, eds. 2016. Muslim Tatar Minorities in the Baltic Sea Region. Leiden: Brill 2016.

Terzioğlu, Derin. 2013. “How to Conceptualize Ottoman Sunnitization: A Historiographical Discussion." Turcica 44: 301-338.

Tolan, John. 1996. "Anti-Hagiography: Embrico of Mainz's Vita Mahumeti." Journal of Medieval History 22 (1): 25-41.

Tolan, John, Gilles Veinstein, and Henry Laurens. 2012. "General Introduction." In Europe and the Islamic World, edited by Henry Laurens, John Tolan, and Gilles Veinstein, 12-17. Princeton: Princeton University Press. 
Tommasino, Pieter Mattia. 2018. "Roman Prophet or Muslim Caesar: Muhammad the Lawgiver Before and After Machiavelli." In Machiavelli, Islam and the East. Reorienting the Foundations of Modern Political Thought, edited by Lucio Biasiori and Giuseppe Marcocci, 79-103. Cham: Palgrave Macmillan.

Truschke, Audrey. 2018. "The Power of the Islamic Sword in Narrating the Death of Indian Buddhism." History of Religions 57 (4): 406-435.

United Nations. 2018. "The UN Regional Commissions." Accessed August 14, 2018. http://www.regionalcommissions.org/about/the-regional-commissions.

Unwin, Tim. 2000. "A Waste of Space? Towards a Critique of the Social Production of Space..." Transactions of the Institute of British Geographers 25 (1): 11- 29.

Vajda, G. 1978: "Isrā'îlīyāt." The Encyclopaedia of Islam, 2nd ed., vol. IV, edited by P. Bearman, Th. Bianquis, C.E. Bosworth, E. van Donzel, and W.P. Heinrichs, 211b-212b. Leiden: Brill.

Van de Kamp, Linda. 2016. "Introduction: Religious Circulation in Transatlantic Africa." African Diaspora 9: 1-13.

Van Ess, Josef. 1999. "Sufism and Its Opponents. Reflections on Topoi, Tribulations, and Transformations." In Islamic Mysticism Contested. Thirteen Centuries of Controversies and Polemics, edited by Frederick de Jong and Bernd Radtke, 22-44. Leiden: Brill.

-_- 2011. DerEine und das Andere. Beobachtungen an islamischen häresiographischen Texten, 2 vols. Berlin/New York: De Gruyter.

Vaziri, Mostafa. 2015. Rumi and Shams' Silent Rebellion. Parallels with Vedanta, Buddhism, and Shaivism. Basingstoke: Palgrave Macmillan.

Versteegh, Kees. 1990. "The Arab Presence in France and Switzerland in the 10th Century." Arabica 37 (3): 259-388.

Vogel, Christian. 2016. “Produkt unorganisierter Expansion? Die Berber-Enklave Fraxinetum." In Transkulturelle Verflechtung. Mediävistische Perspektiven, edited by Georg Christ et al., 197-202. Göttingen: Universitätsverlag Göttingen.

Von Oppen, Achim. 2001. "The Making and Unmaking of Boundaries in the Islamic World: Introduction." Die Welt des Islams 41 (3): 277-286.

Voll, John. 1994. "Islam as a Special World-System." Journal of World History 5 (2): 213226.

Waardenburg, Jacques, ed. 1999. Muslim Perceptions of Other Religion. A Historical Survey. Oxford: Oxford University Press.

-- - 2004. "Muslim Studies of Other Religions: The Medieval Period." In Muslims and Others in Early Islamic Society, edited by Robert Hoyland, 211-240. Aldershot: Ashgate. 
Wallerstein, Immanuel. 1980-1989. The Modern World-System, 3 vols. New York: Academic Press.

Weatherford, Jack M. 2005. Genghis Khan and the Making of the Modern World. New York: Crown.

Welsch, Wolfgang. 2017. Transkulturalität. Realität - Geschichte - Aufgabe. Wien: new academic press.

Weltecke, Dorothea. 2012. “Multireligiöse Loca Sancta und die mächtigen Heiligen der Christen." Der Islam 88 (1): 73-95.

Wild, Stefan. 1994. “'Die schauerliche Öde des heiligen Buches'. Westliche Wertungen des koranischen Stils." In Gott ist schön und er liebt die Schönheit. Festschrift für Annemarie Schimmel zum 7. April 1992 dargebracht von Schülern, Freunden und Kollegen, edited by Alma Giese and J. Christoph, 429-447. Bern: Peter Lang. Würsch, Renate. 2013. "Der Koran und seine Rezeption." Das Mittelalter 18 (1): 27-45. Yusuf, Imtiyaz. 2010. "Islam and Buddhism Relations from Balkh to Bangkok and Tokyo." In The Muslim World 100, 177-186.

-_- 2013. "Islam and Buddhism," In The Wiley-Blackwell Companion to InterReligious Dialogue, edited by Catherine Cornille, 360-375. Chichester: Wiley Blackwell.

Zilfi, Madeline C. 2009. Art. "Slavery." In Encyclopedia of the Ottoman Empire, edited by Gábor Ágoston and Bruce Master, 530-533. New York: Facts on File.

Zürcher, Erik Jan. 1998. "The Ottoman Conscription System, 1844-1914." International Review of Social History 43: 437-449. 